$$
\text { في بيان مصطلح (القول الحثيث الحديث) }
$$

$$
\begin{aligned}
& \text { إعداد الدكتور } \\
& \text { وليد عبد الرحيم إبراهيم عبد الرحيم } \\
& \text { مدرس الحديث وعلومله بجامعة البراهيم الأزهر } \\
& \text { كلية الدرآسات الإسلامئدة والعربية } \\
& \text { بنين بلدمياط الجديدة }
\end{aligned}
$$




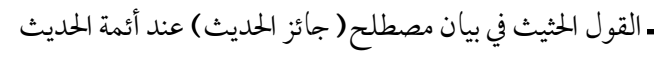

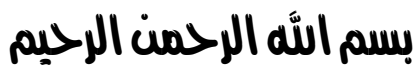

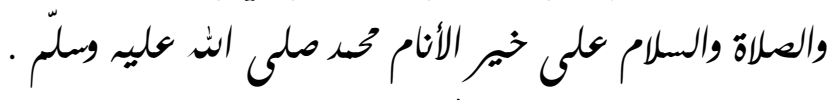

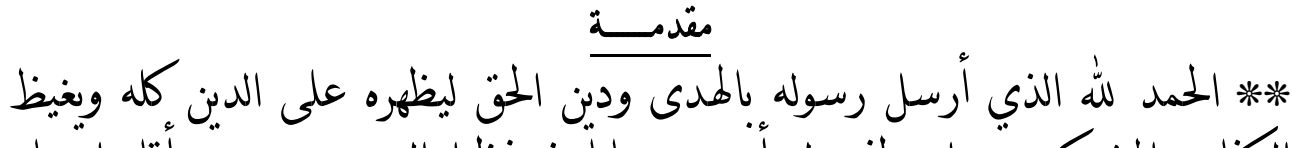

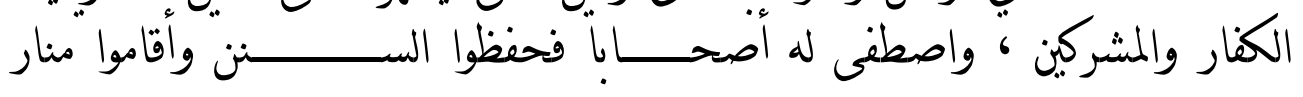

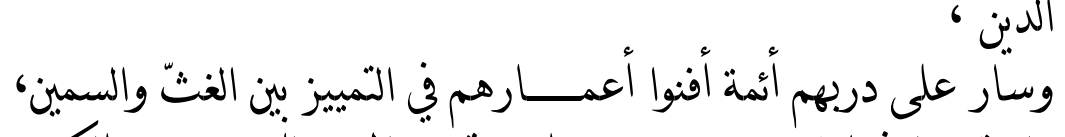

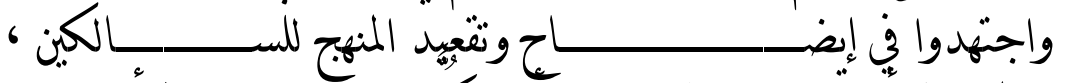

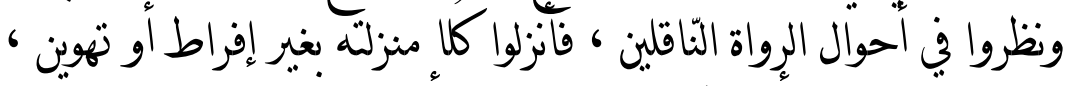

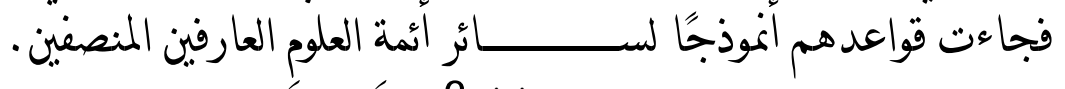

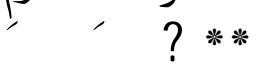

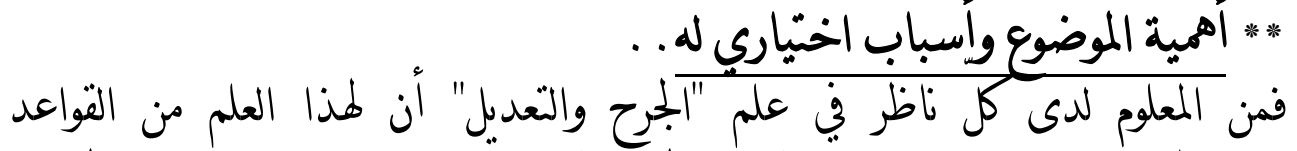

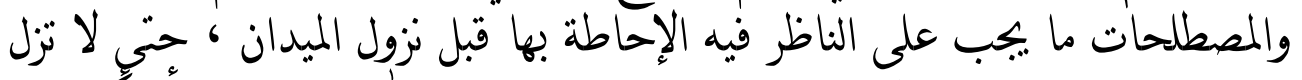

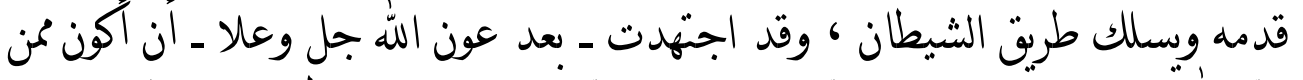

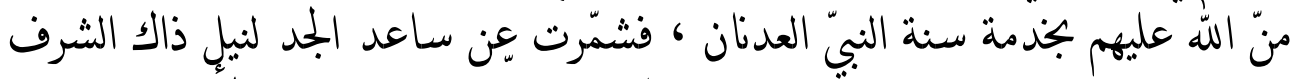

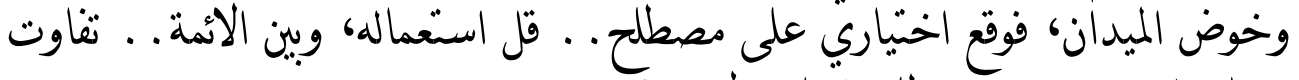

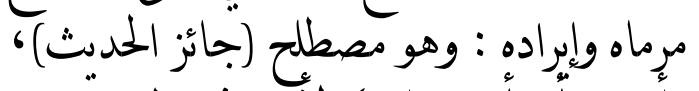

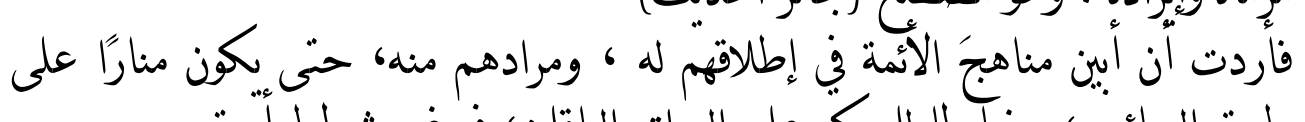

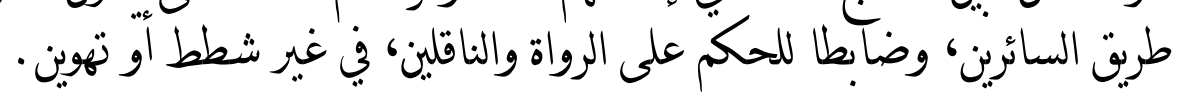

وقد جاء بحثا لطيفا في قسمين :

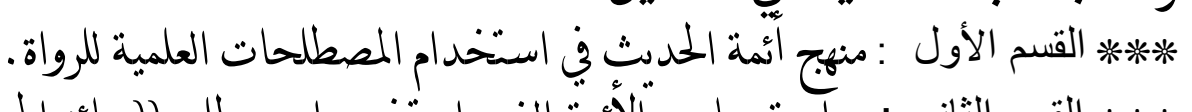

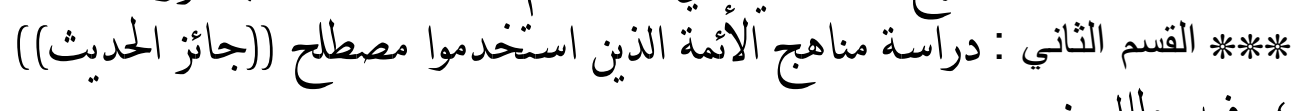

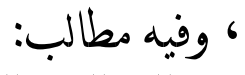

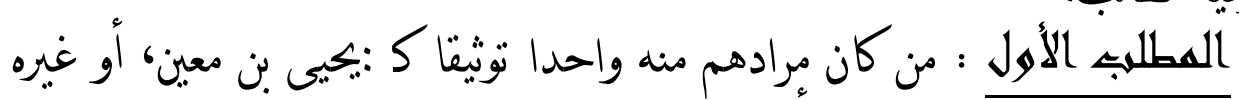
كالإمامبن : مسلمة بن القاسم، وأبي داود . 


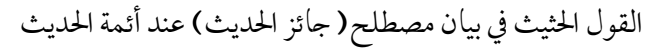

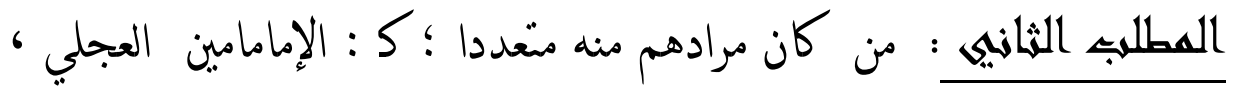

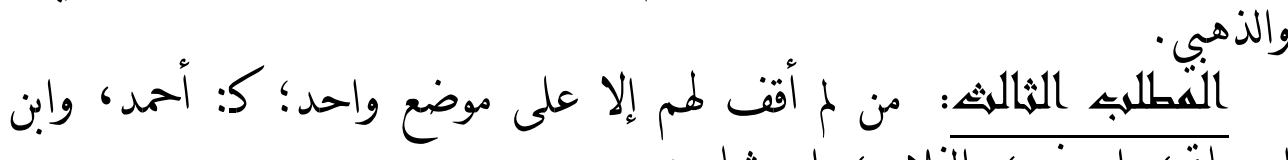

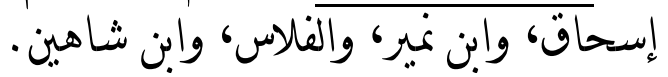

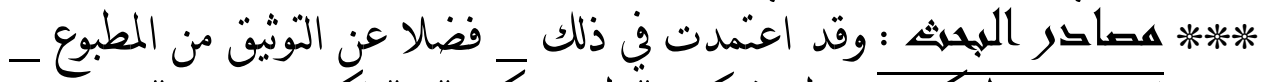

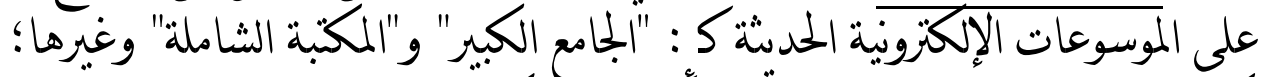

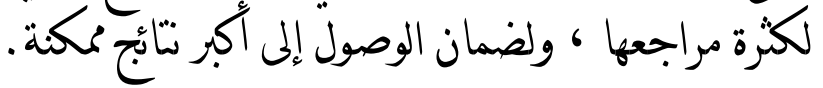

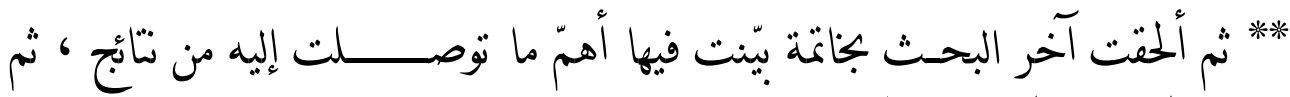
فهرس المراجع والموضـــوعات.

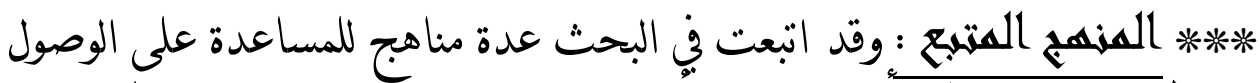

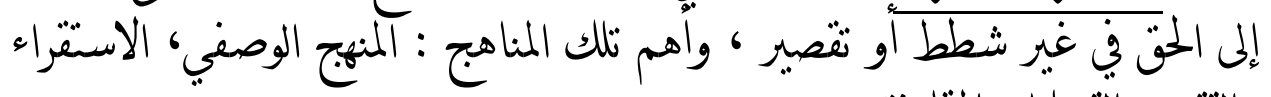

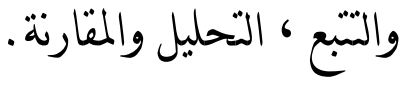




\section{الاقسم الأول

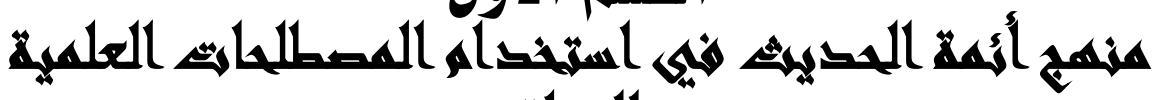 ilged}

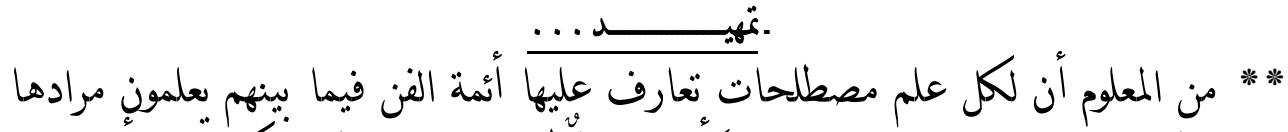

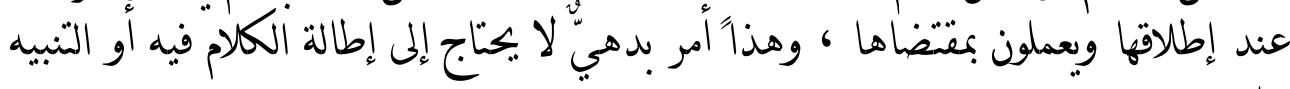
عليه.

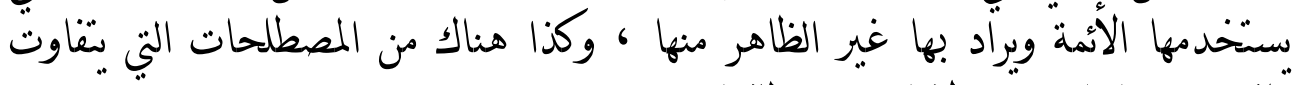

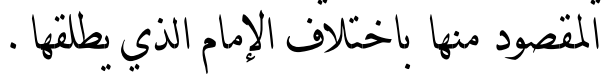

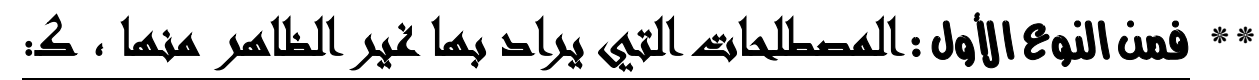

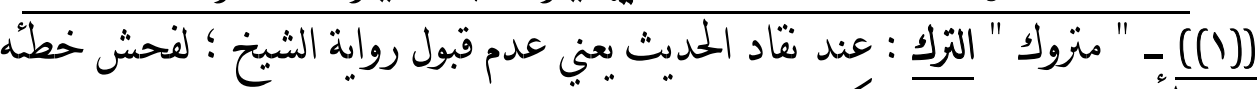

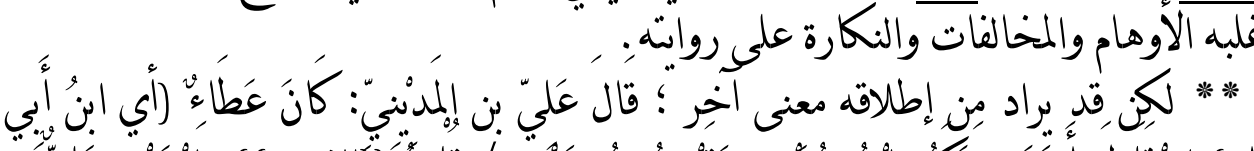

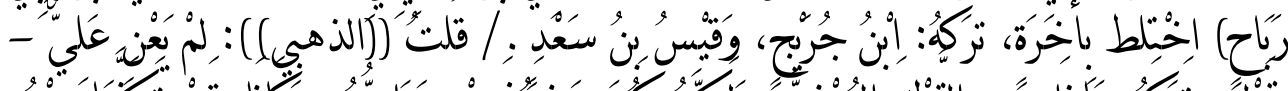

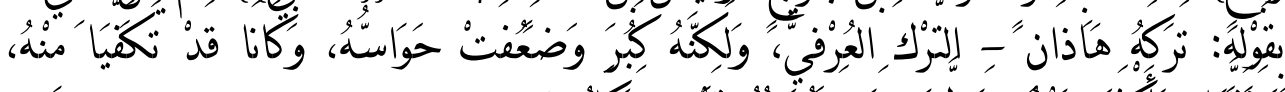

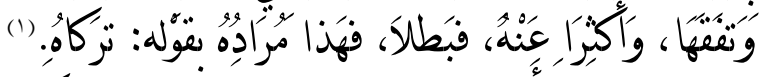
قال

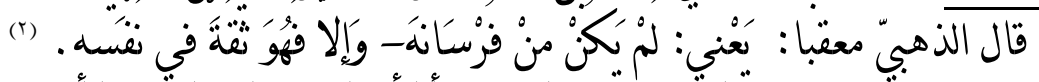

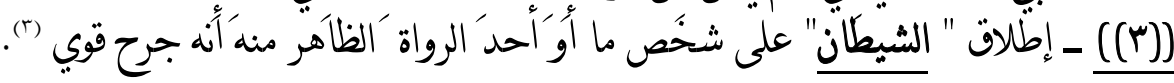

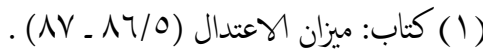

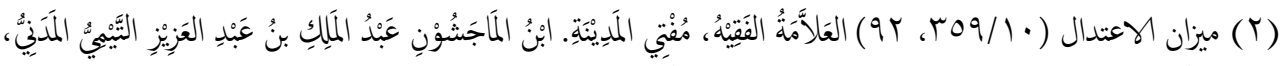

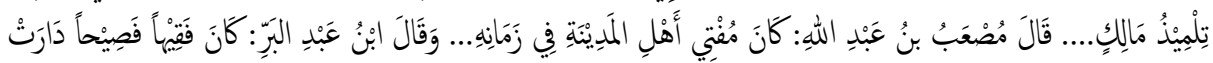

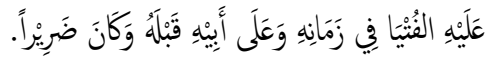

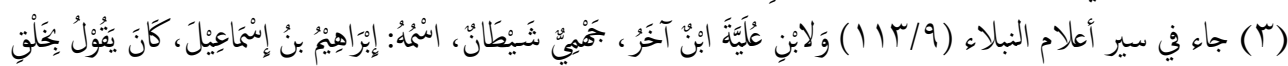
القُرَآنِ، وَيْنَاظِرُ.

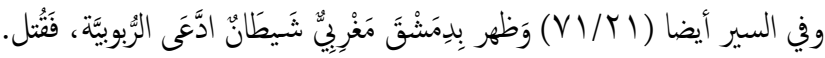




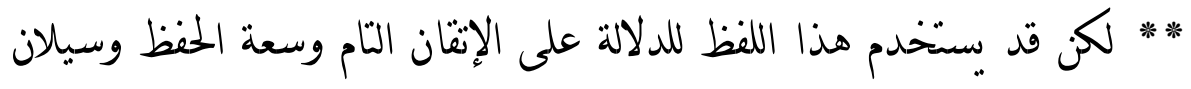

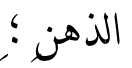

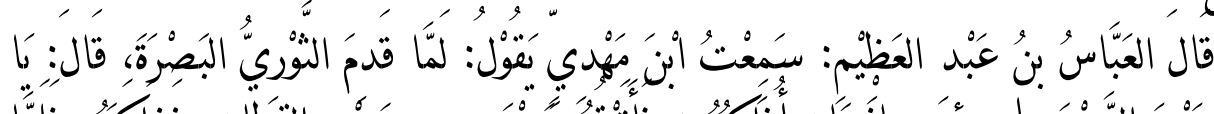

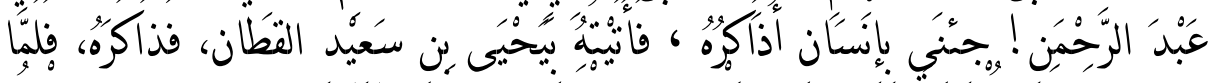

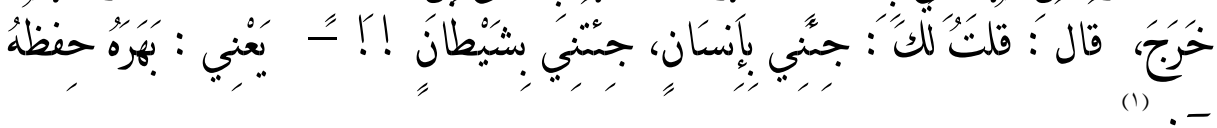

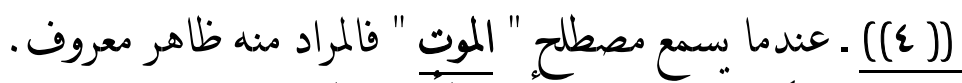

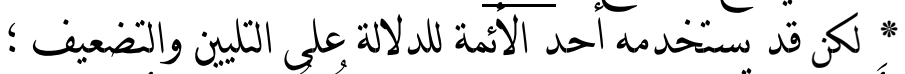

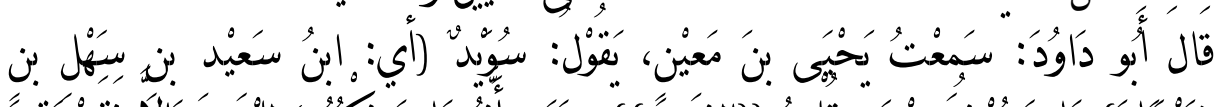

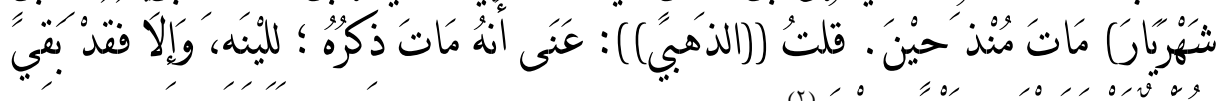

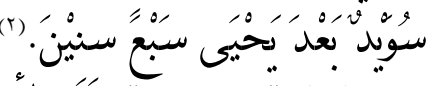

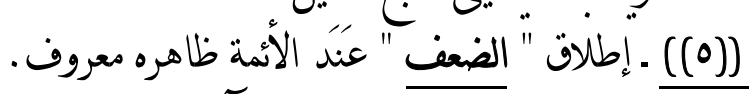

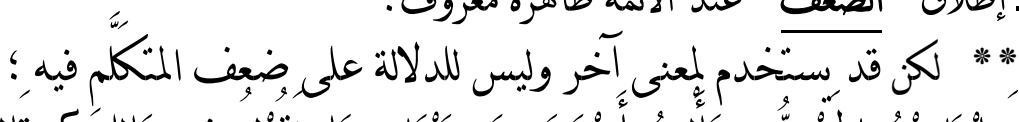

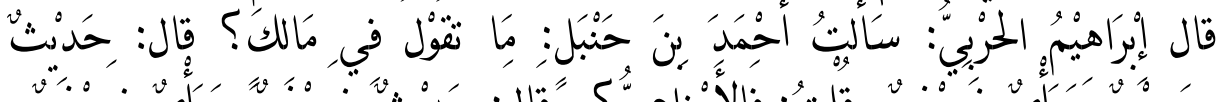

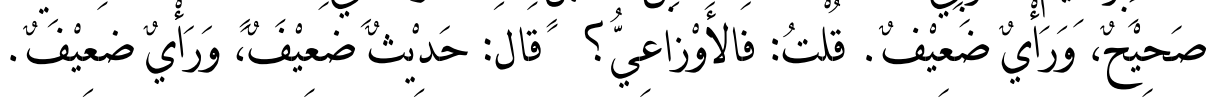

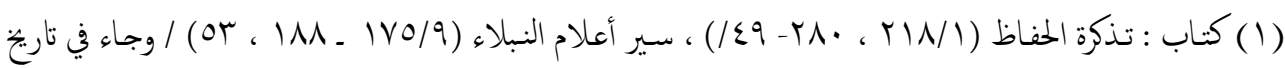

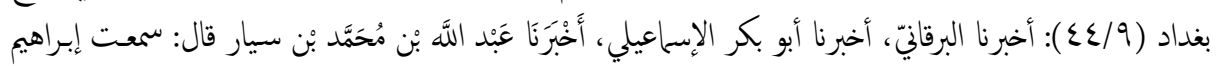

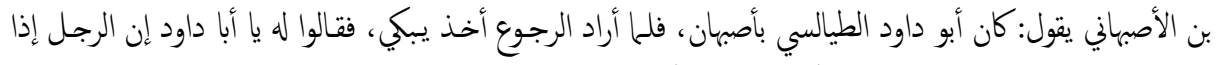

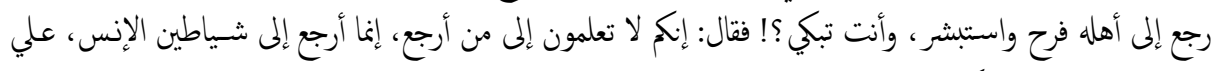

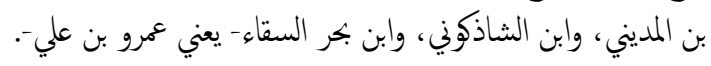

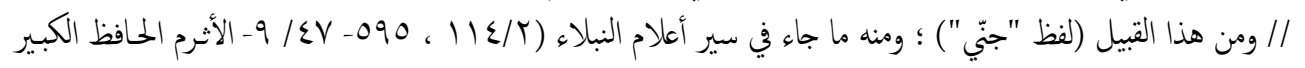

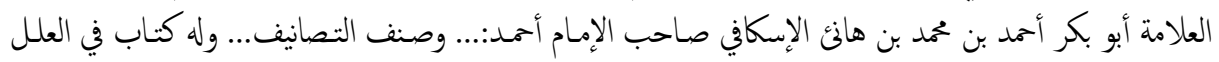

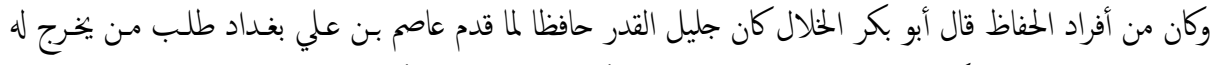

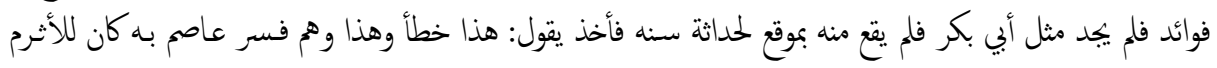

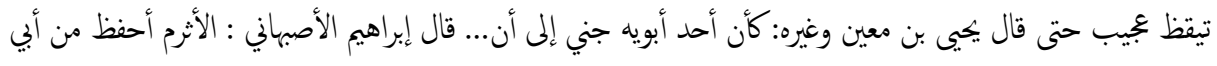

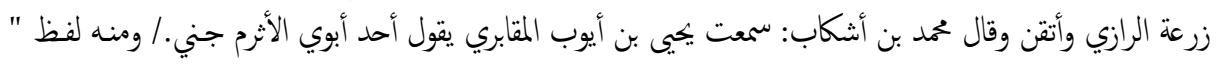
لصّ " سيأتي في ترجمة إسرائيل السبيعي.

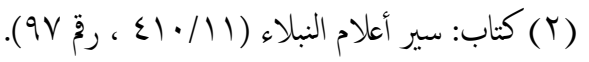




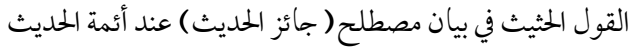

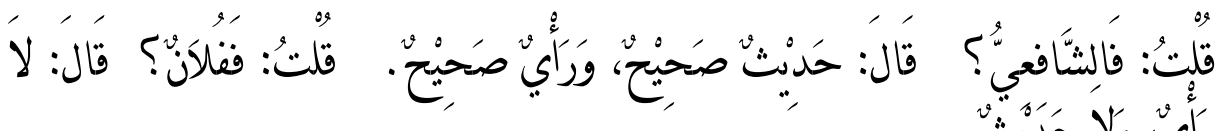

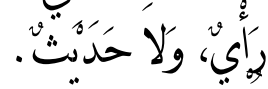

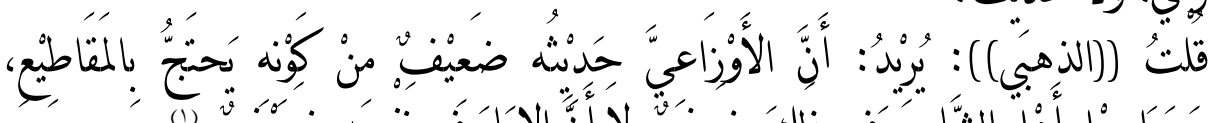

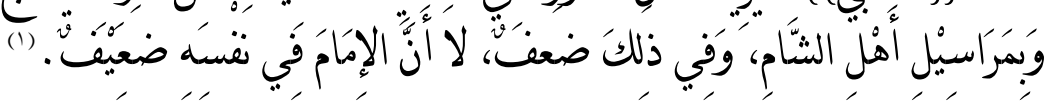

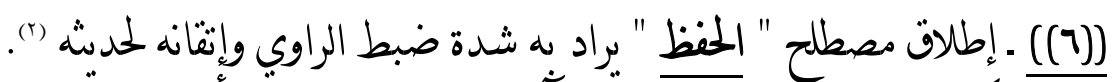

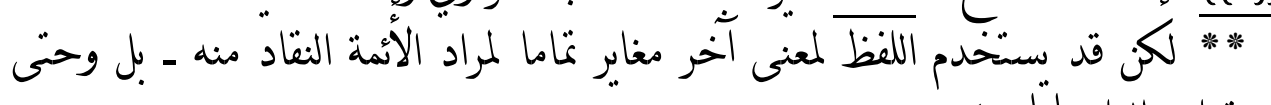

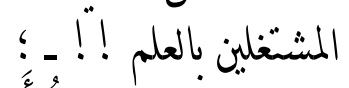

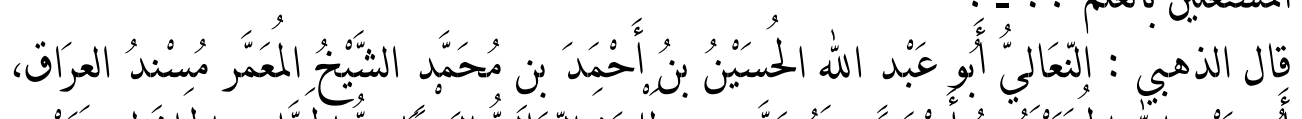

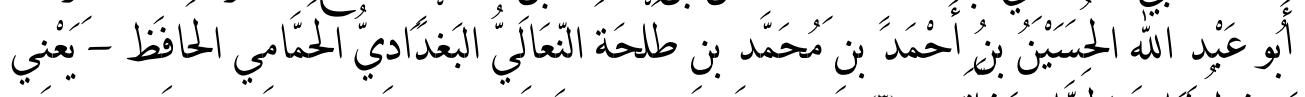

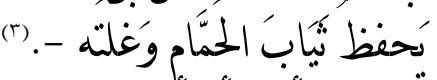

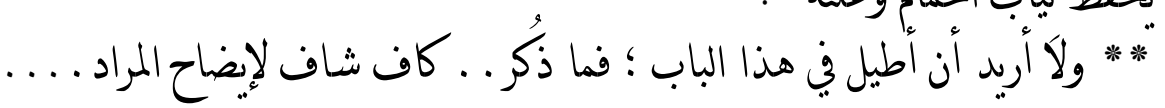

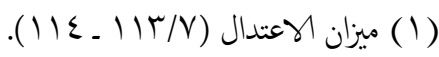

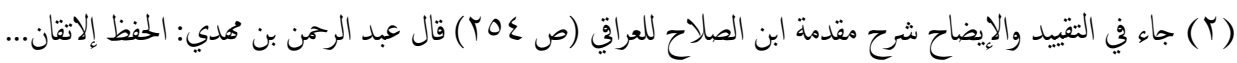

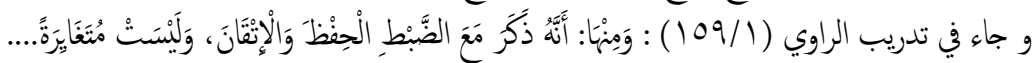

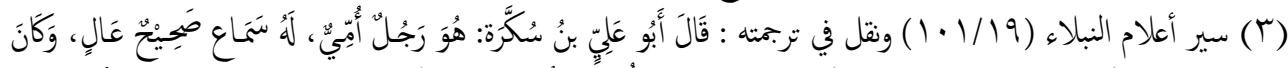

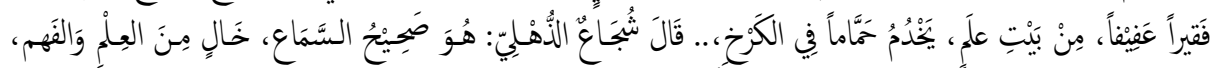

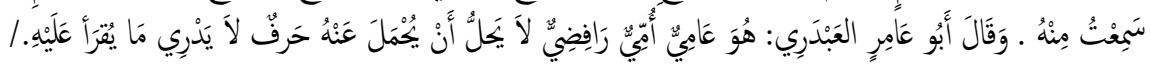

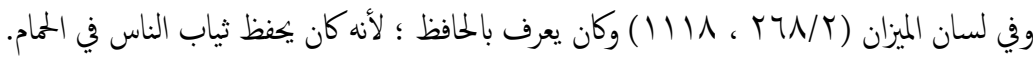




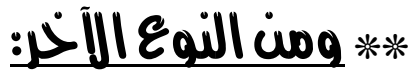

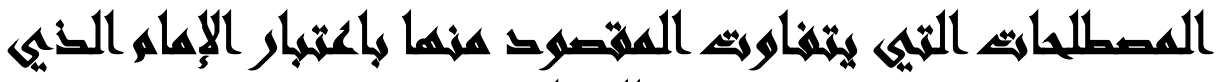

\section{:}

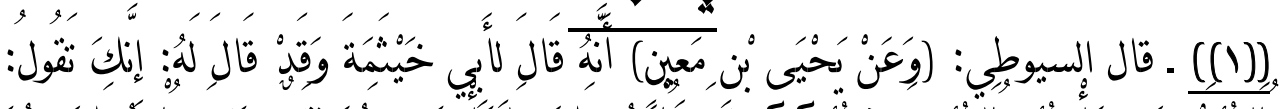

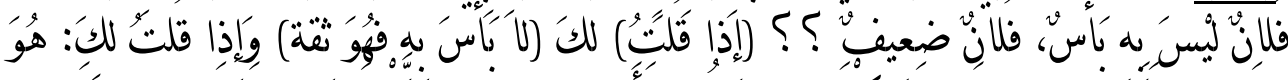

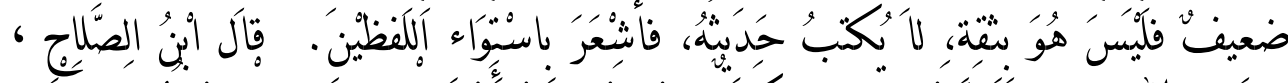

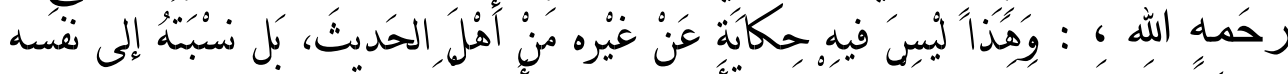

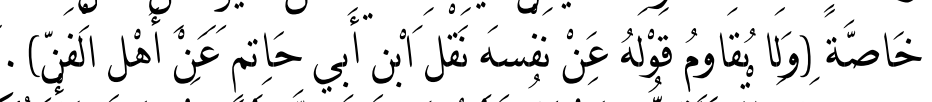

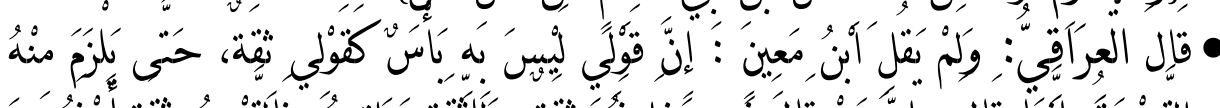

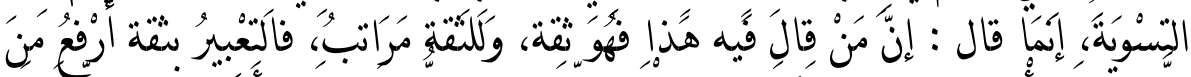

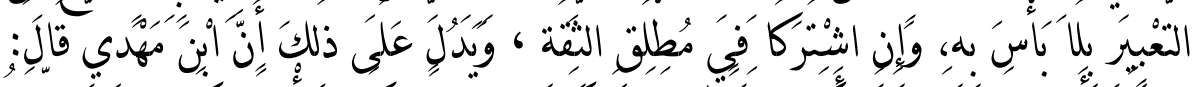

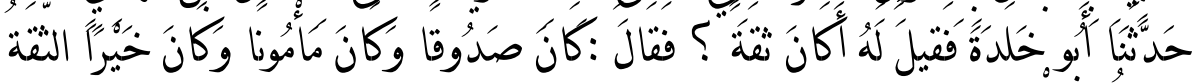

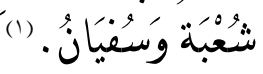

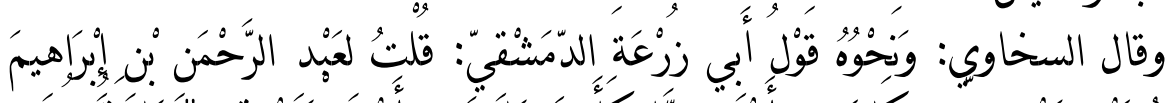

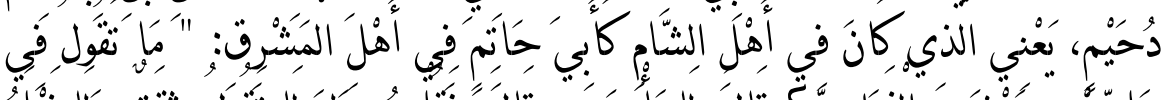

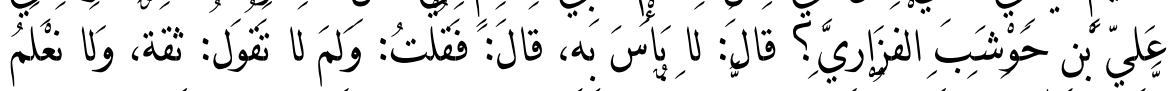

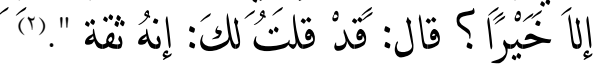

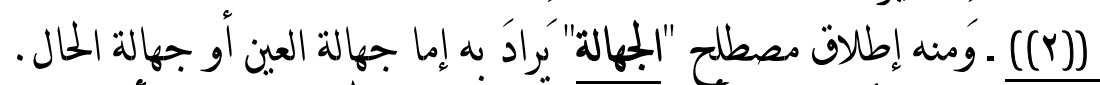

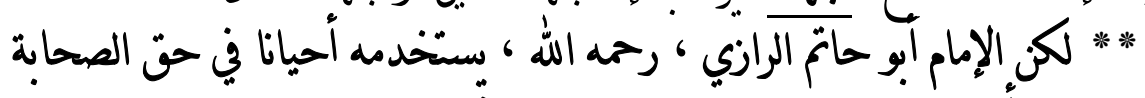

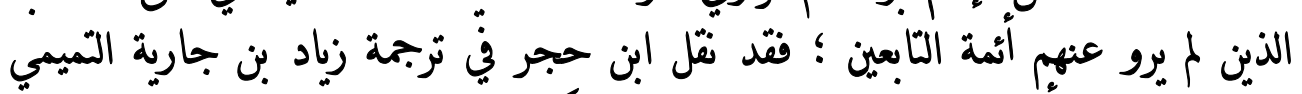

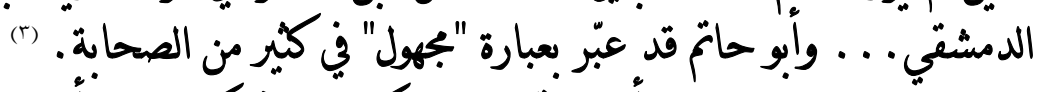

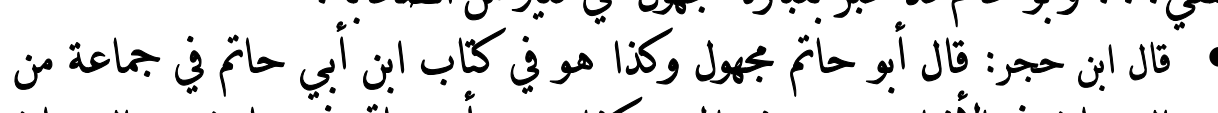

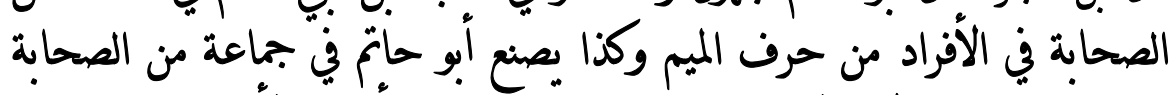

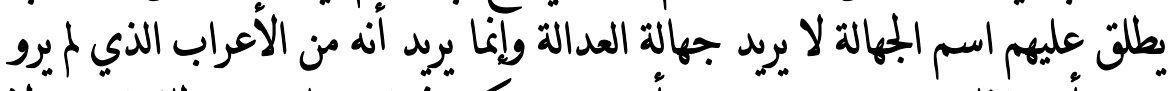

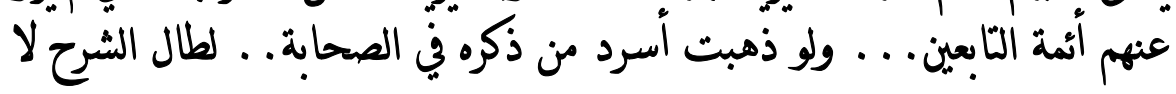

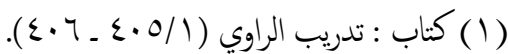

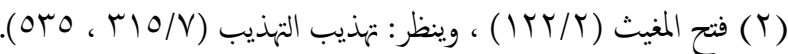

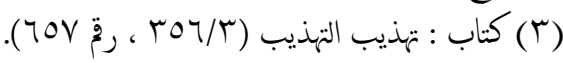




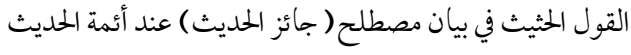

\section{سيما وهذا رجل من أهل بدر لم نّخلف عن ذكره أحد من صنف في

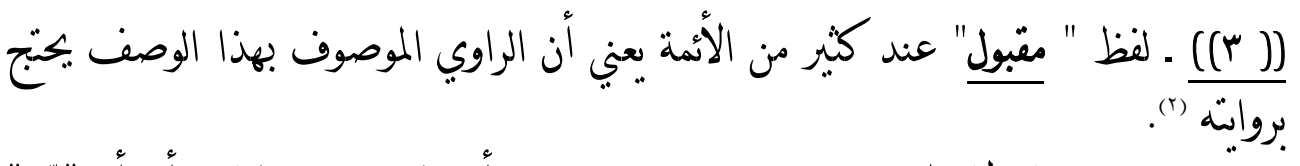

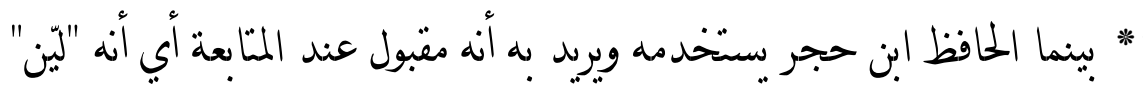

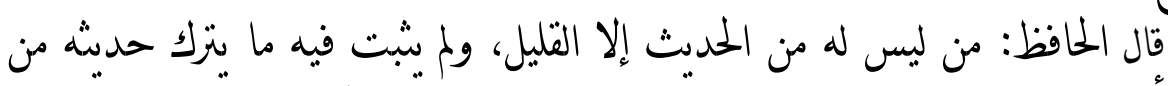

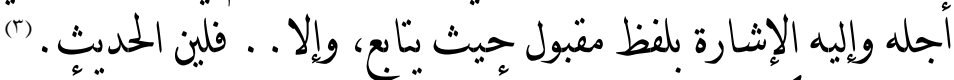

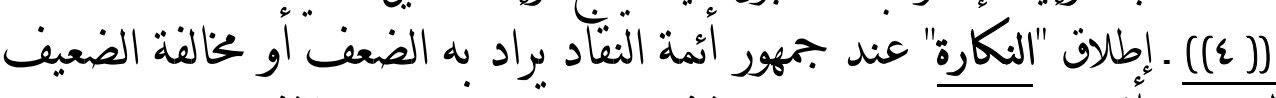

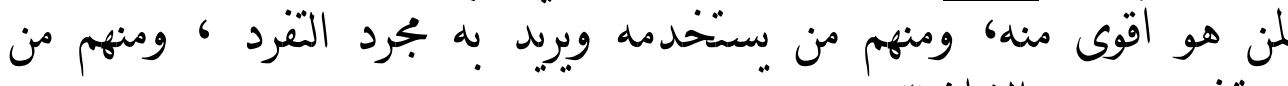

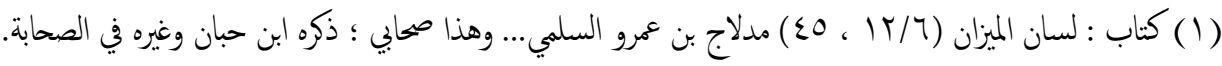

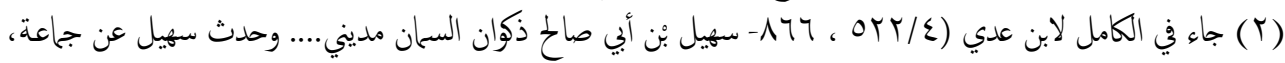

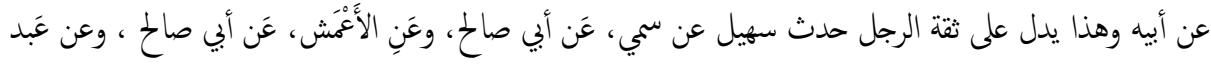

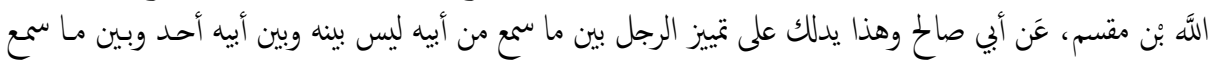

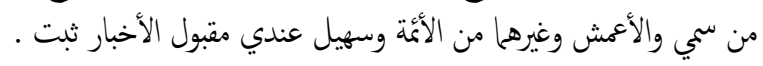

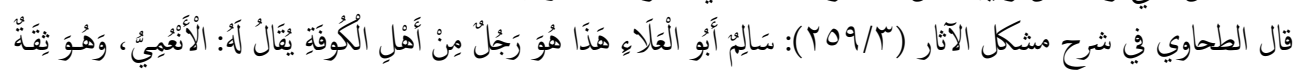

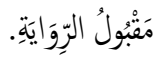

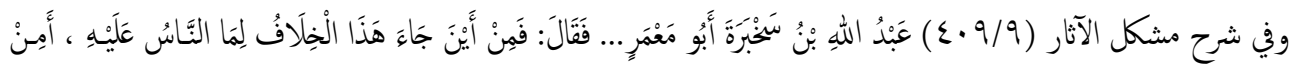

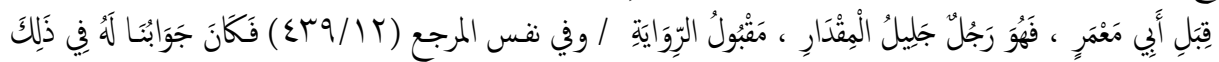

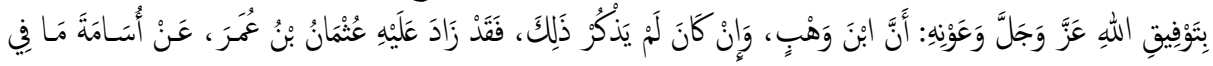

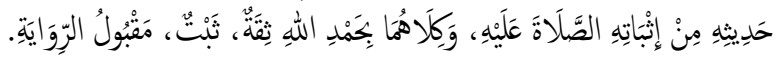

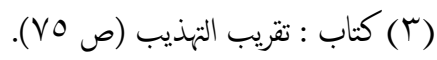

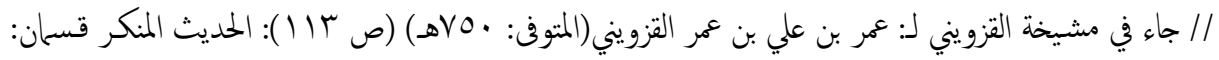

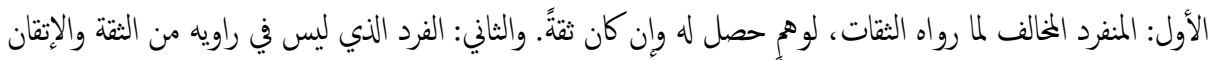

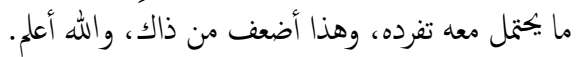

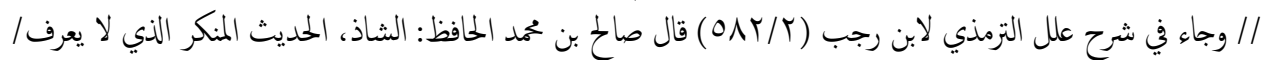

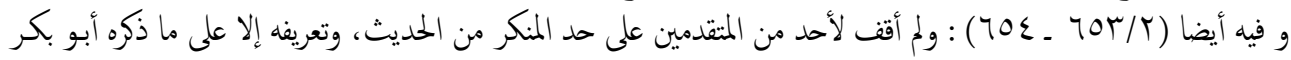

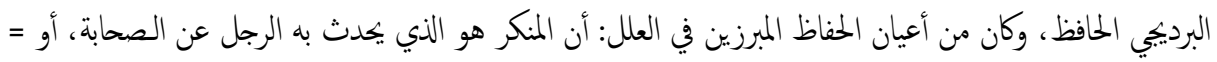



القول الحثيث في بيان مصطلح ( جائز الحديث) عند أئمة الحديث

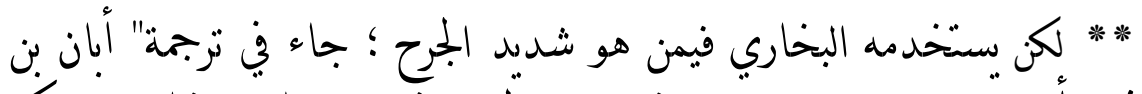

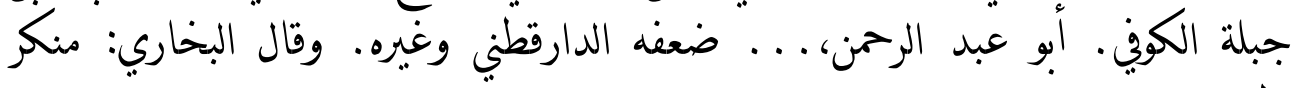
الحدنث.

ونقل ابن القطان أن البخاري قال: كل من قلت فيه منكر الحدبث. .. فلا تحل الرواية عنه. (1)

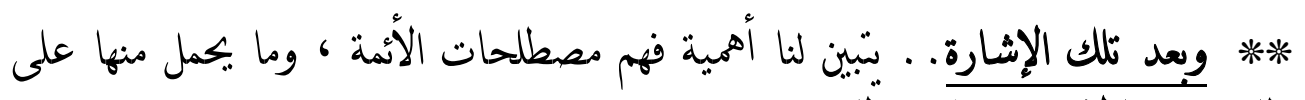

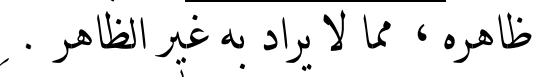

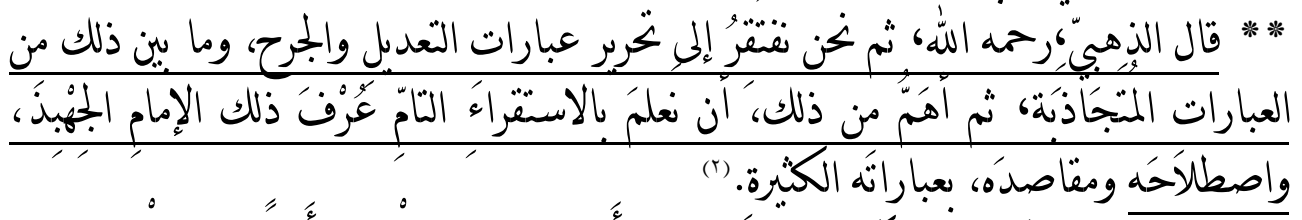

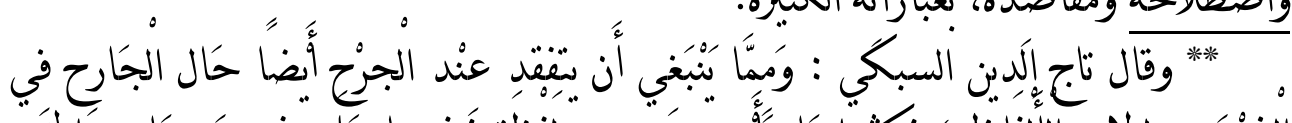

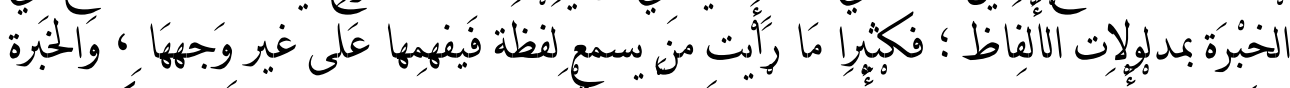

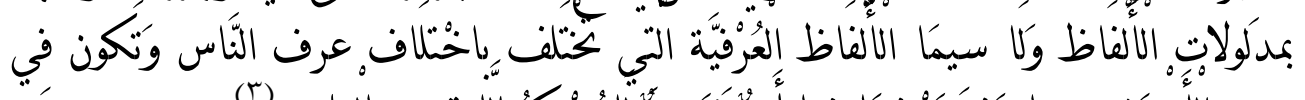

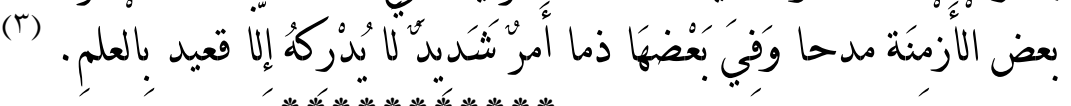

=عن التابعين، عن الصحابة، لا يعرف ذلك الحديث، وهو متن الحديث، إلا من طريق الذي رواه فيكون منكراً.

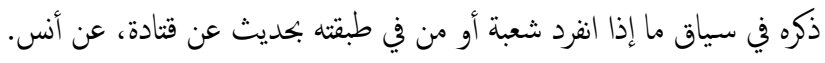

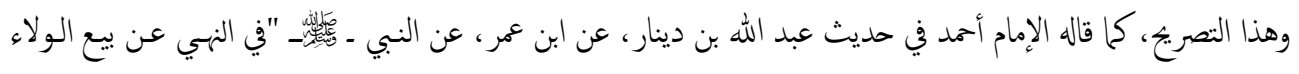
وهبته"....

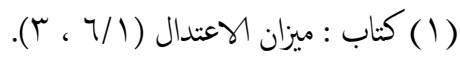

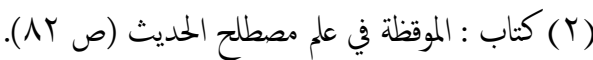

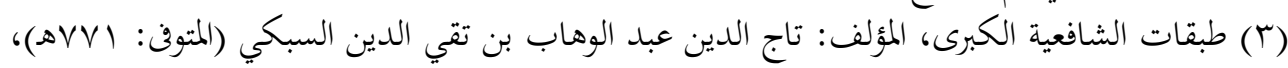

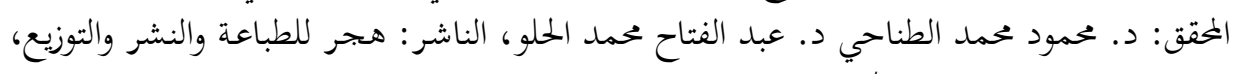

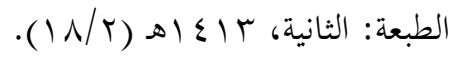




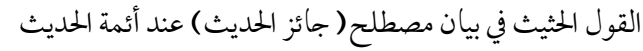

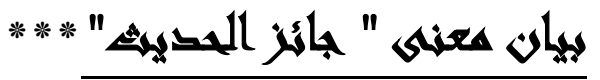

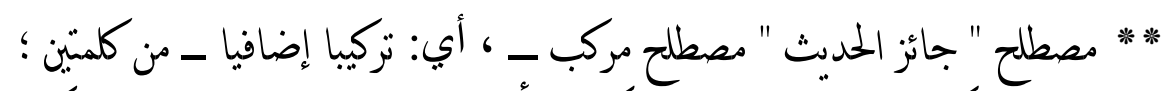

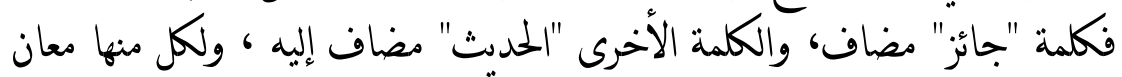

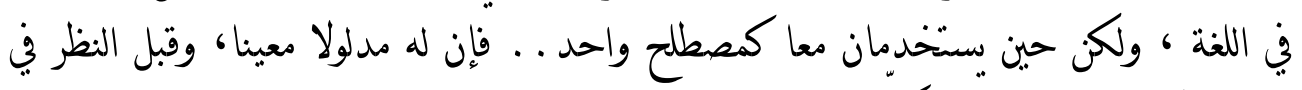

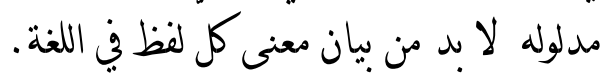

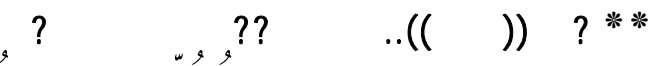

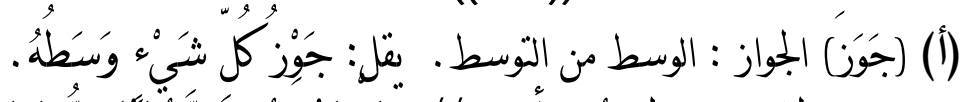

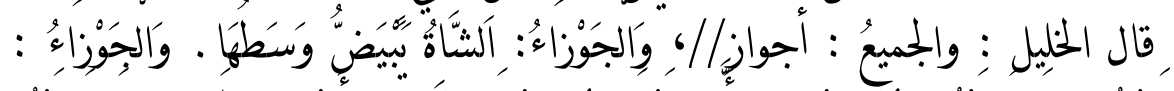

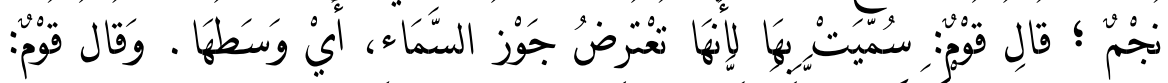

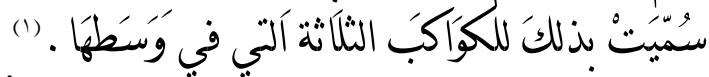

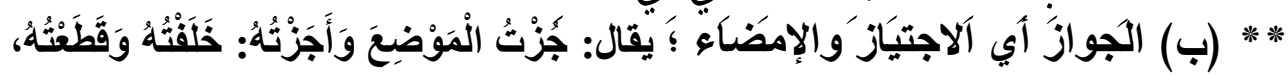

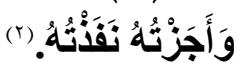

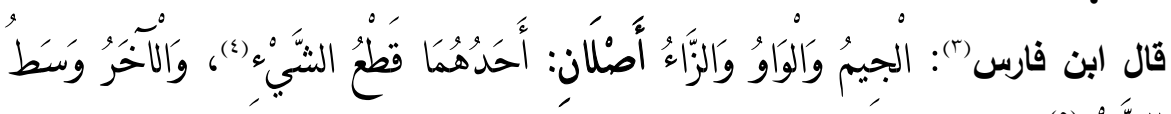

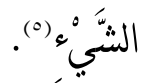

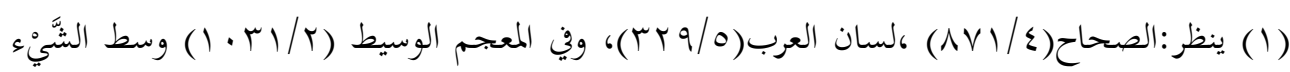

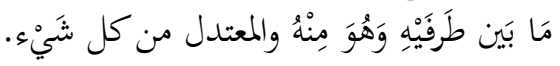

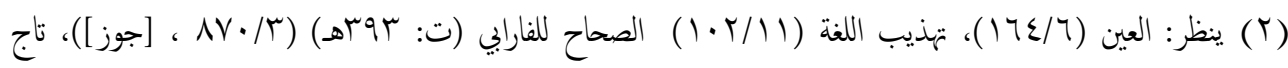

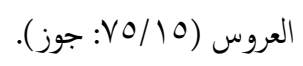

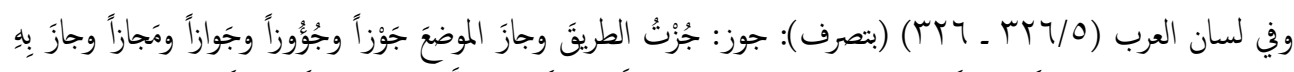

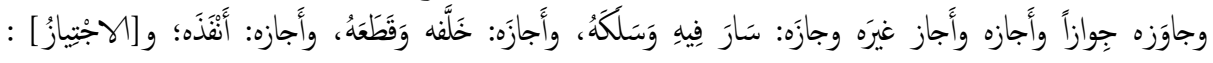

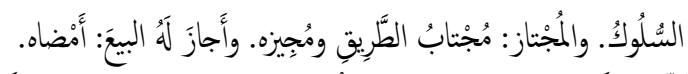

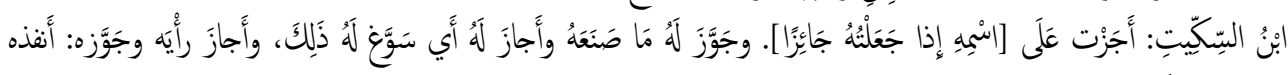
إذا أَمضاه وَجَعَلَهُ جَائزًا.

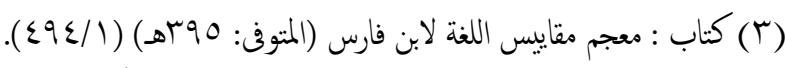

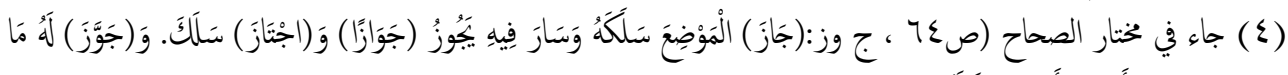

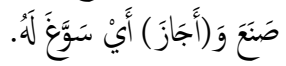

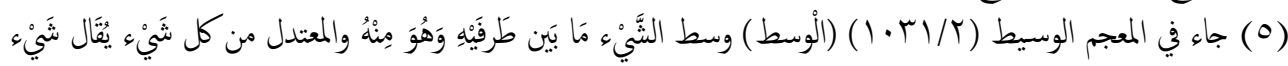
وسط بَّن الْجيد والرديء.... 

القول الحثيث في بيان مصطلح ( جائز الحديث) عند أئمة الحديث

** والجواز عند الفقهاء : . . . ما كان فيه المرء مخيرا بين الفعل والتزك. . . .ومنه المد الجائز.) (1)

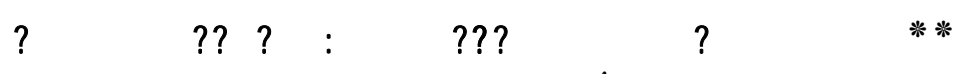

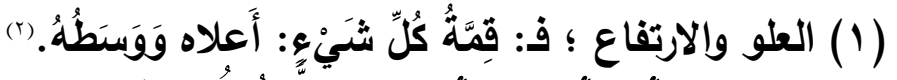

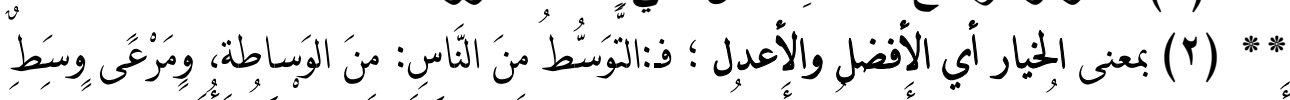

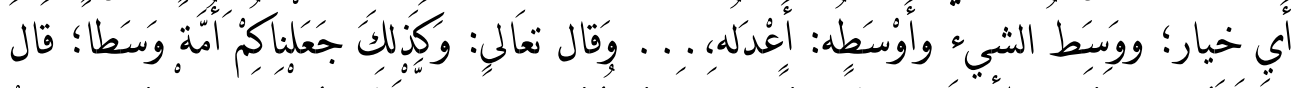

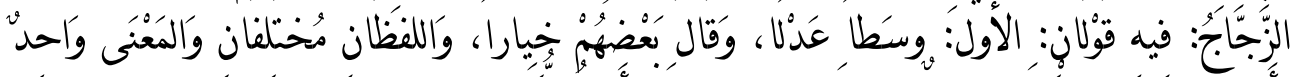

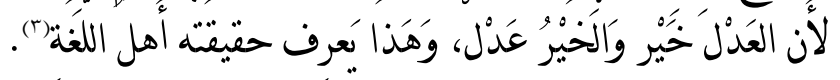

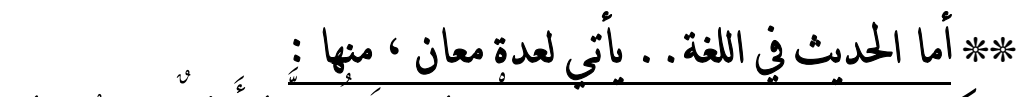

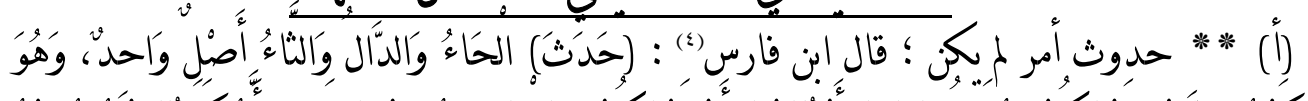

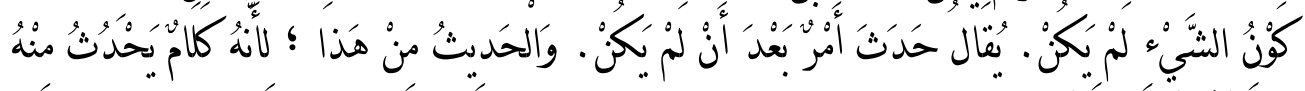

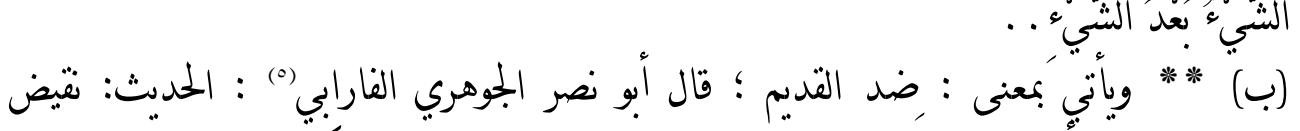

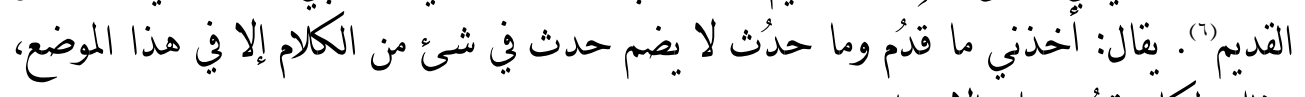
وذلك لمان" قدُم، على الازدواج.

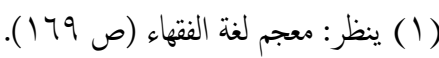

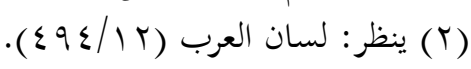

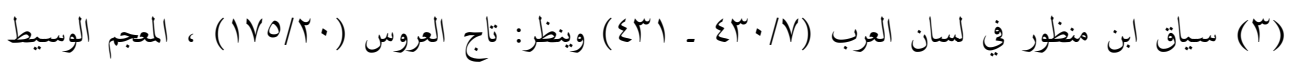
(1. $(1 / T)$

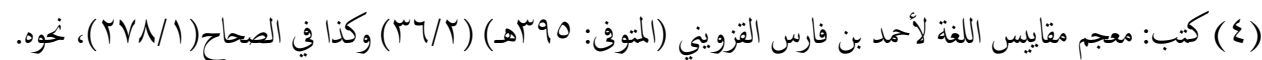

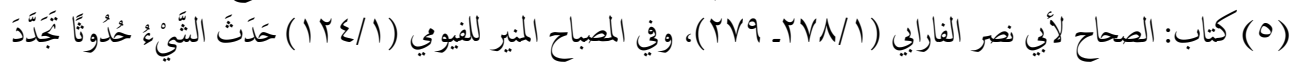

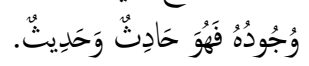

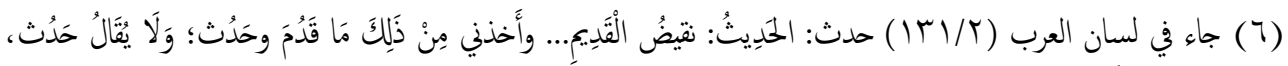

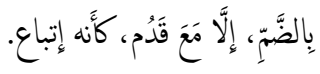




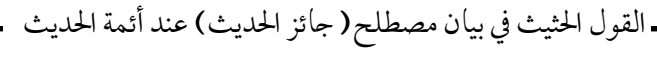

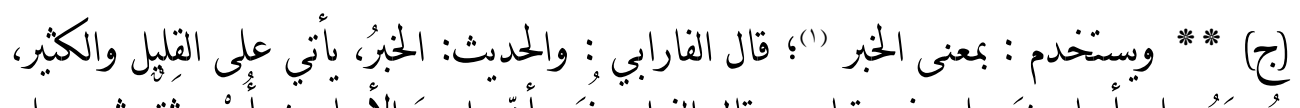

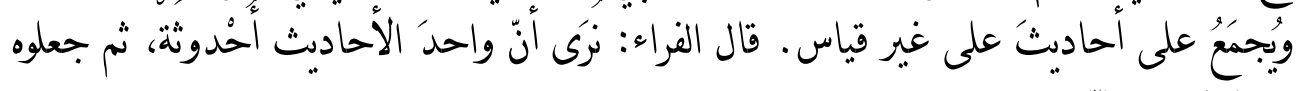

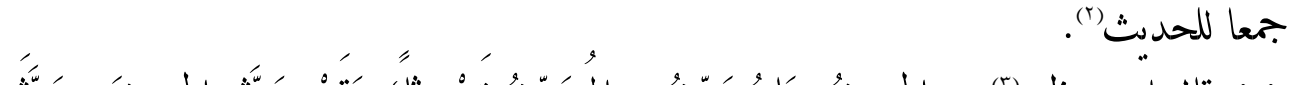

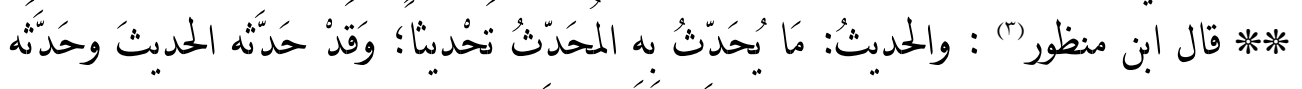
** قلت : والمقصود من هذا كله عند المحدثين - وإن كان يضمن المعاني اللغوية ـ تحديث

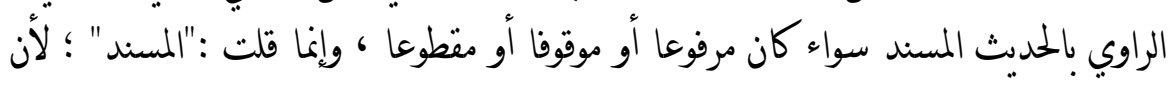
هذا ما بميز المحدثين عن غيرهم حتى صار علما عليهم ، وشعارا لمم ؛ فبالإسناد كميز المتقن من المخطئ ، أو المطروح حدشئه من المقبول.

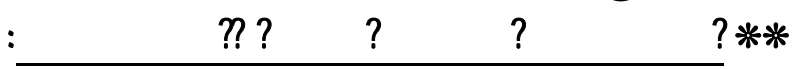

**** وبعد النظر في استخدام أئمة الجرح و التعديل لهذا اللفظ سنجده لايخرج عن تللك المعاني في اللغة ؛ فمنهم من يستخدمه للالالة على اللى الأفضلية أي التوثيق ، ومنهم من بعني به التوسط ، ومنهم من

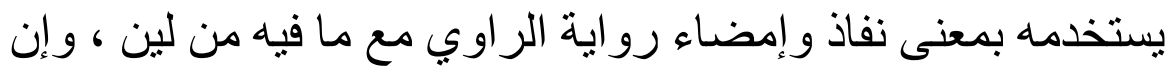
كان في الغالب أن المعنى اللغوي أعم من المعنى الاصطلاحي.

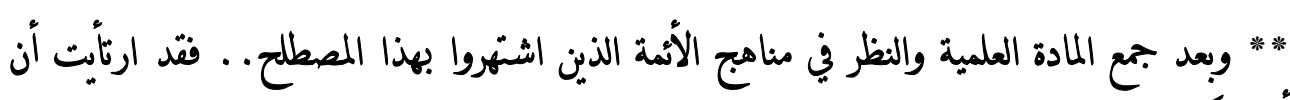

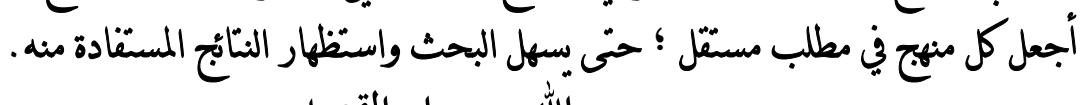
والله من وراء القصد.

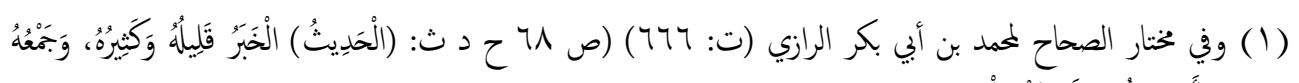

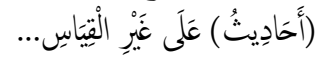

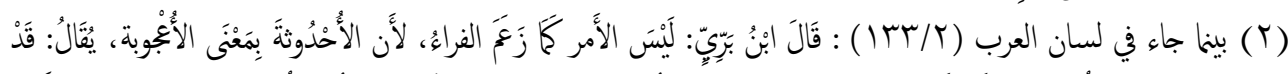

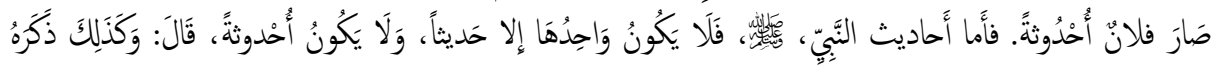


=

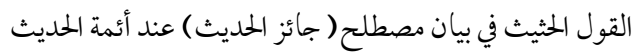




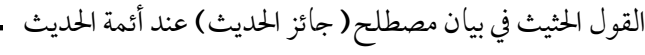

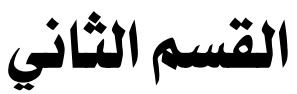 \\ دراسة مناهج الأيمة الذين استخدموا مصطلح ((جائز الحديث))

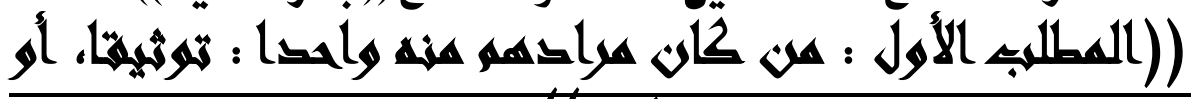

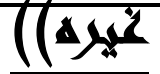

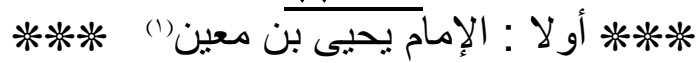

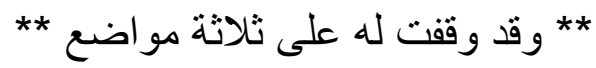

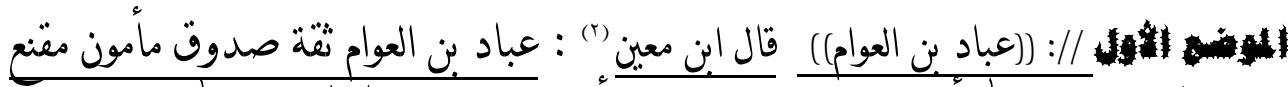

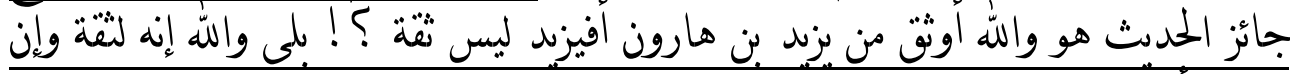

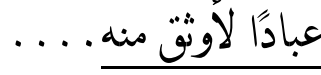

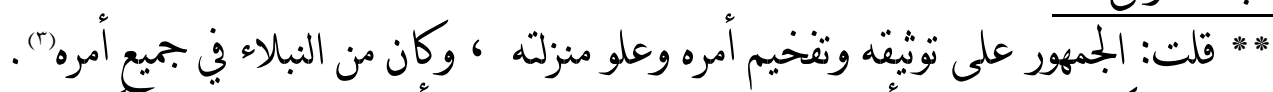

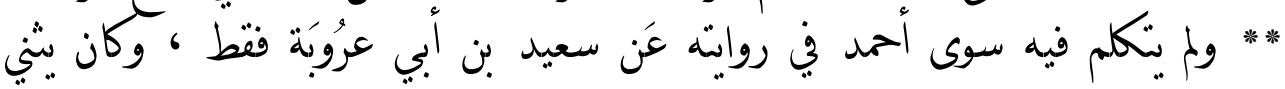
عليd《)(s)

: (1)

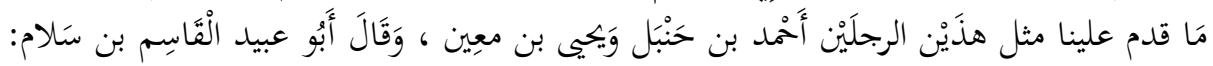

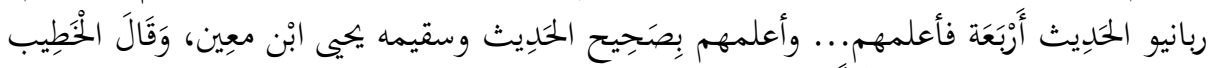

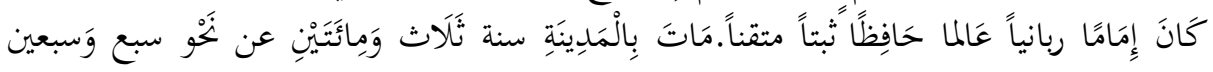

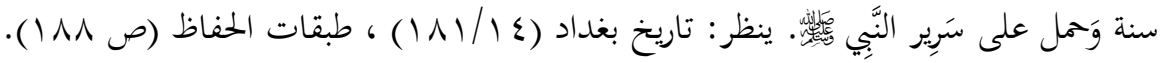

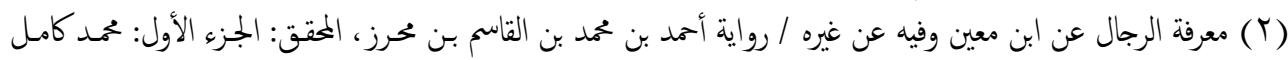
القصار ، (1/ع • (1).

(T) جاء في التهذيب (19/0 . . . . 1) : قال سعيد بن سليمان حدثنا عباد وكان من نبلاء الرجال في

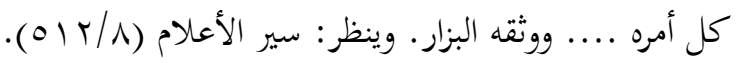

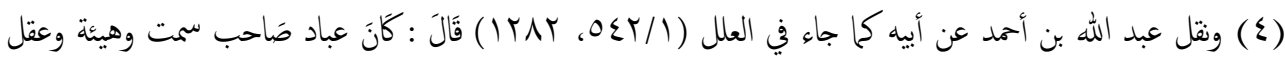
جيد هُوَ أهيأ من ابن أبي زَائيَدة.

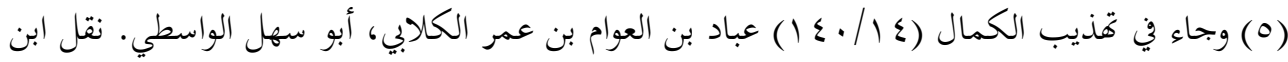

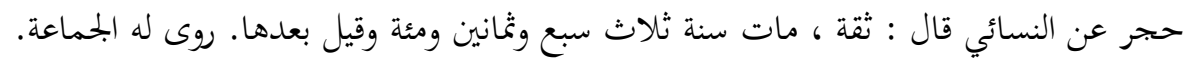

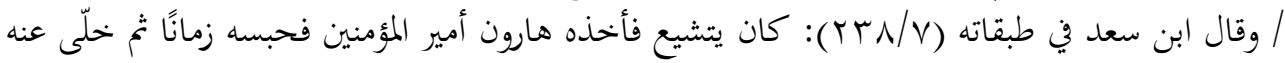

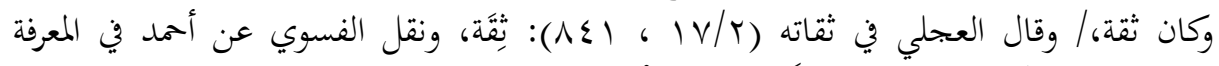

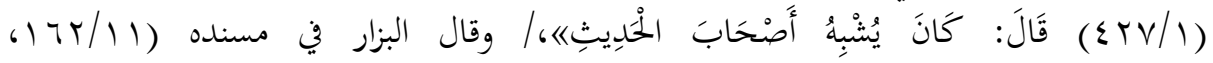

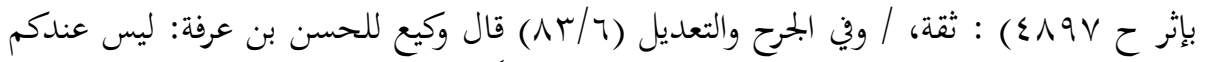

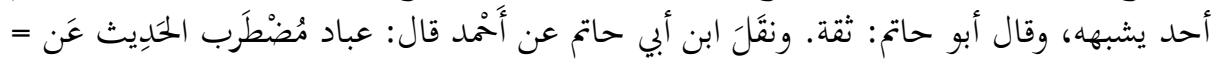




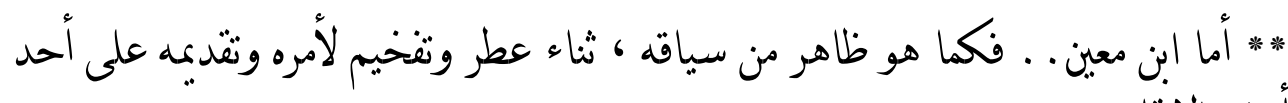
أعلام الإنقان.

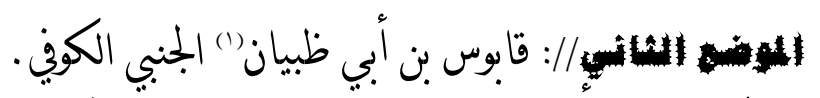

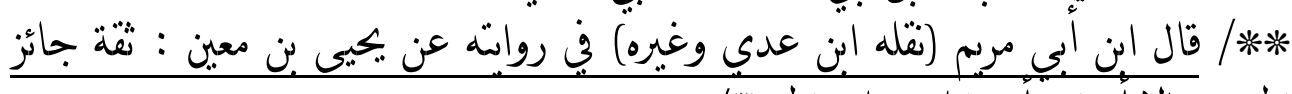

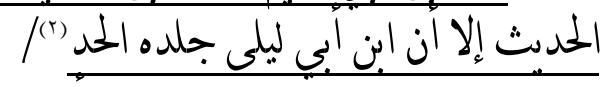

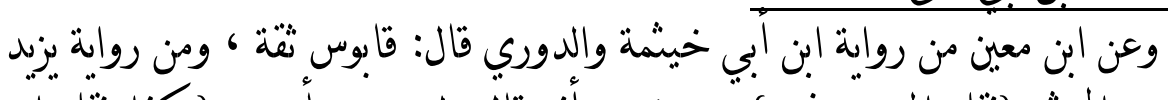

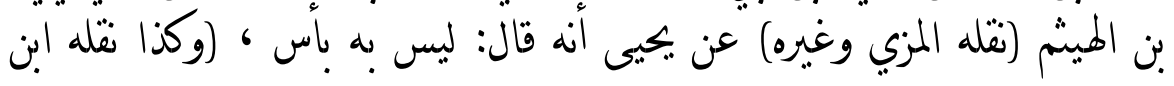

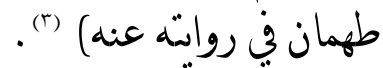

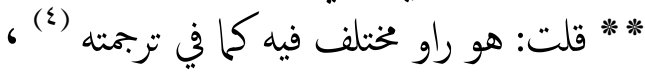

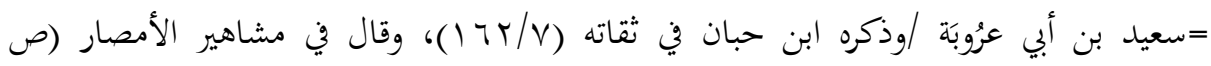

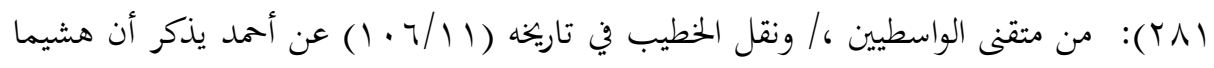

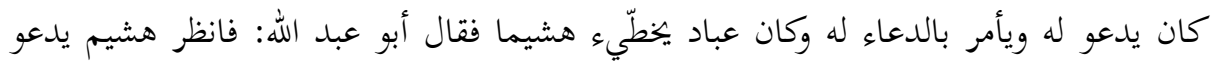

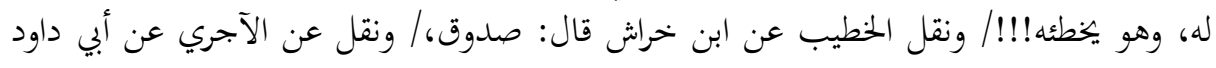

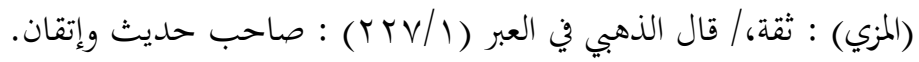

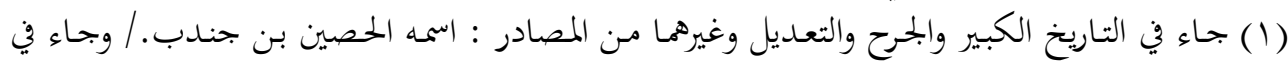

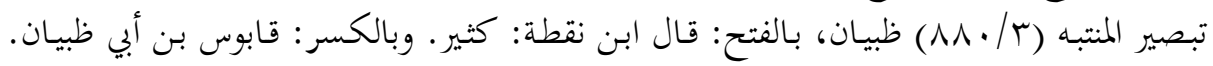

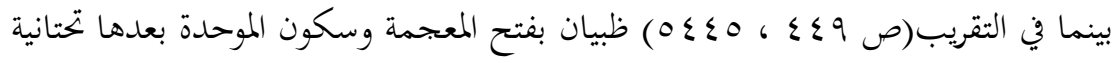

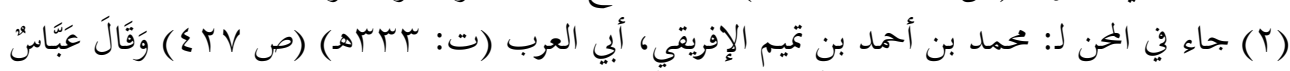

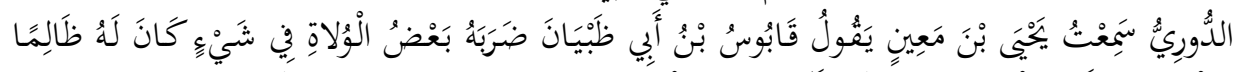

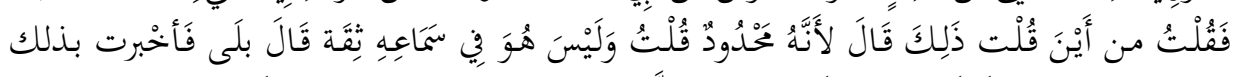

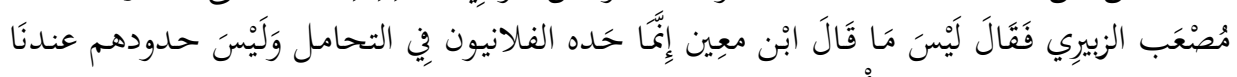

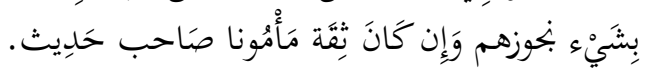

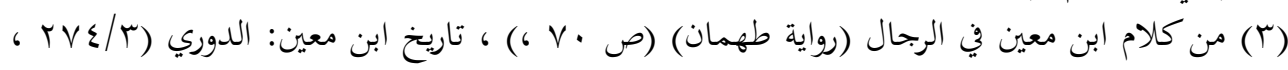

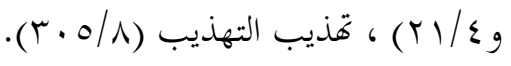

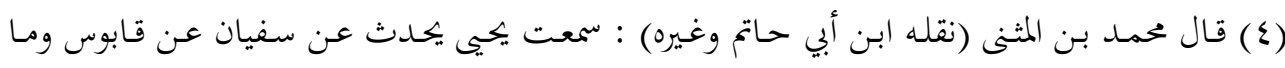

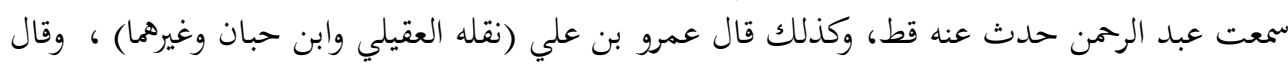

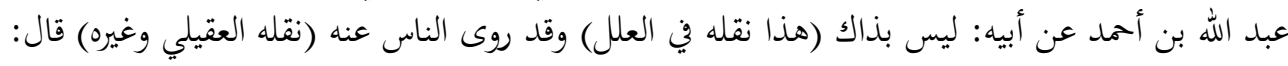

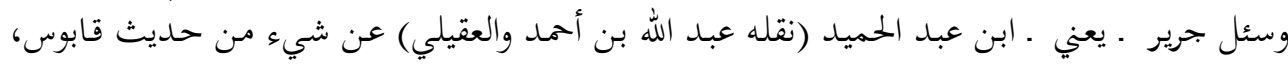

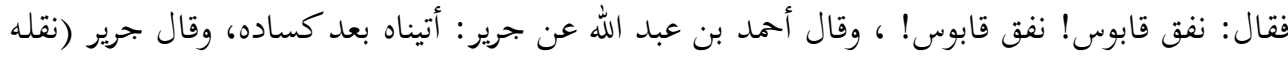

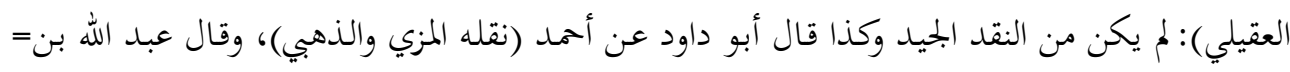




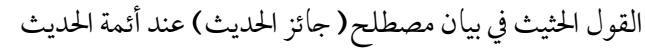

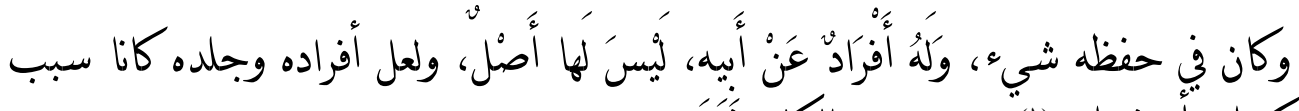

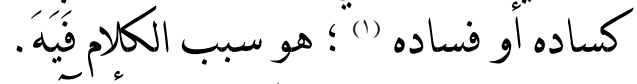

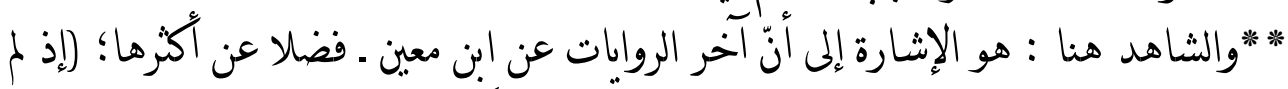

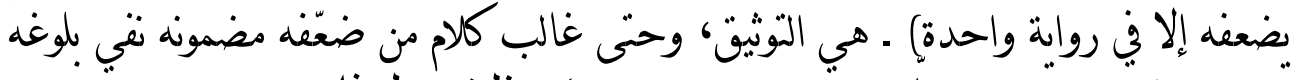

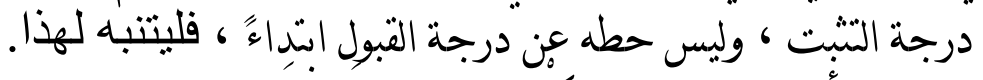

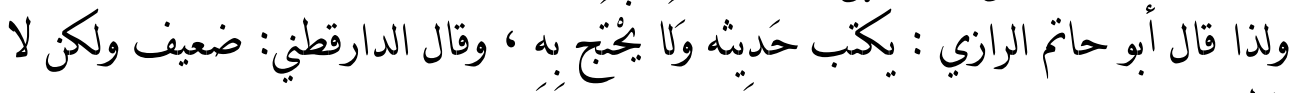

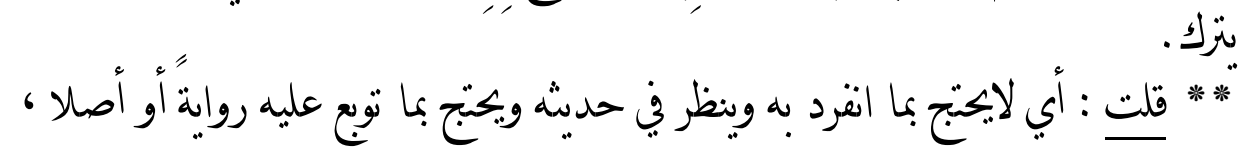

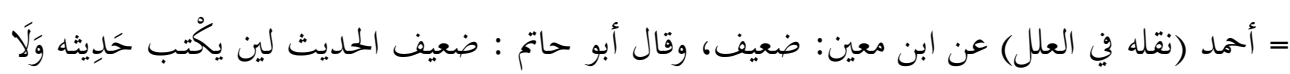

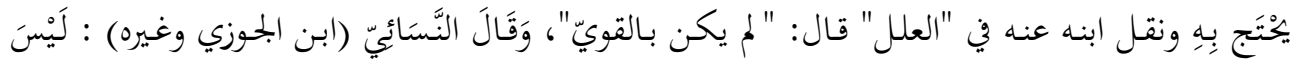

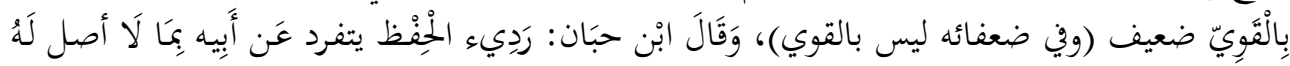

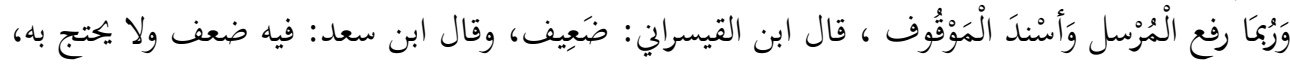

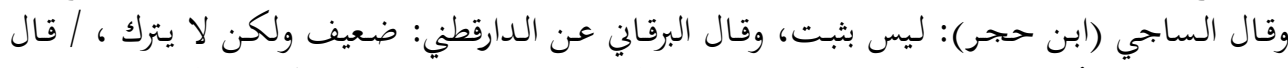

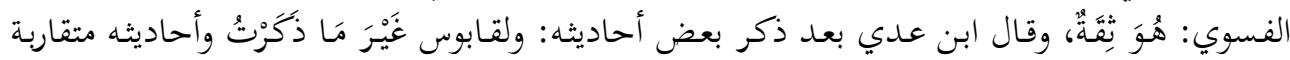

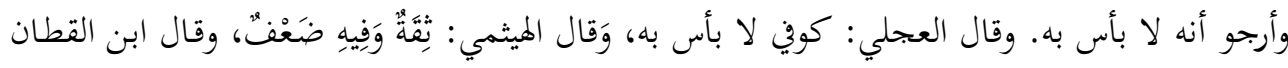

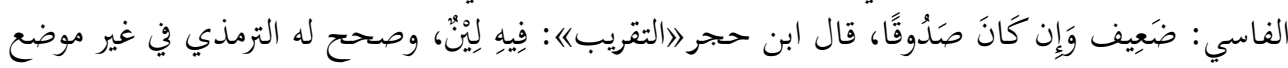

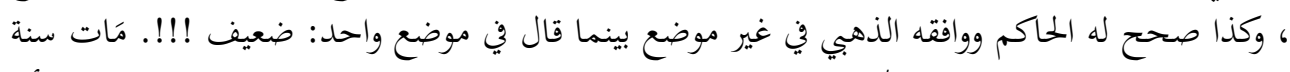

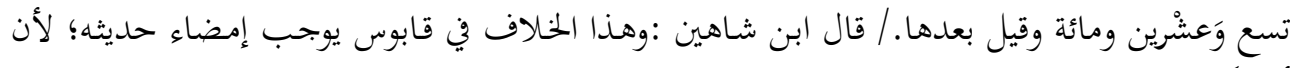

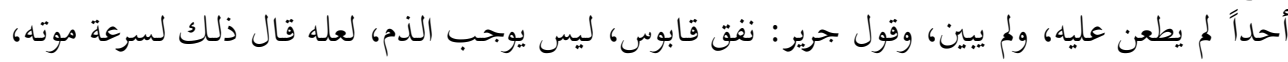

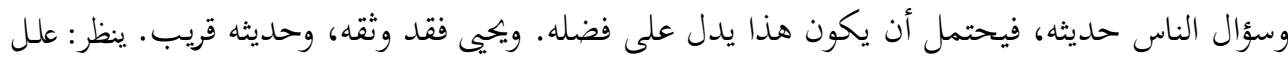

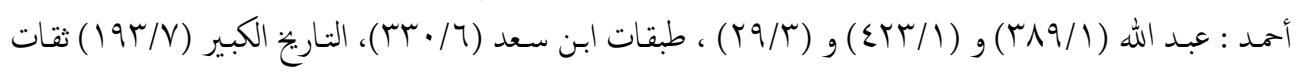

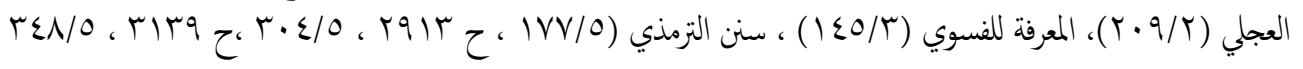
، ح

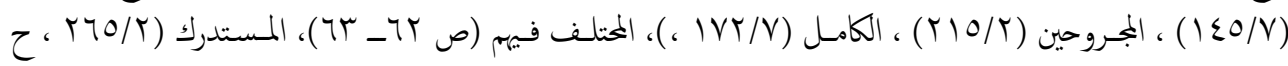
ذهرة

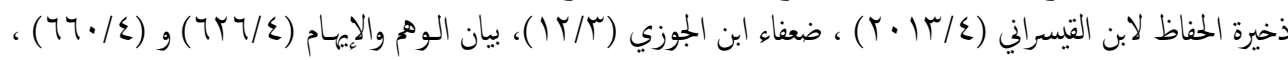

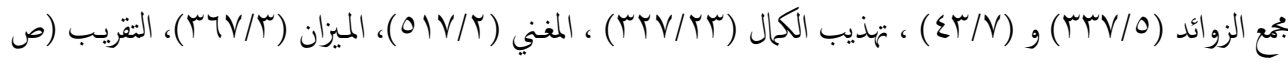

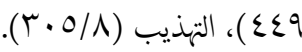

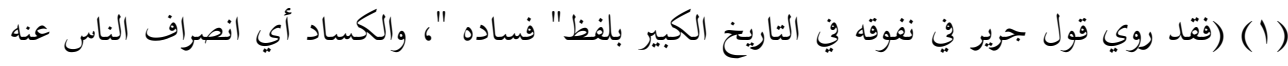
والفساد يطلق على من جُلِلد أيضا). 


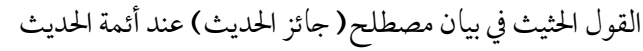

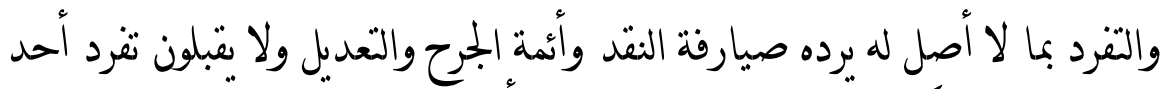

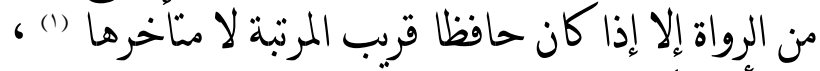

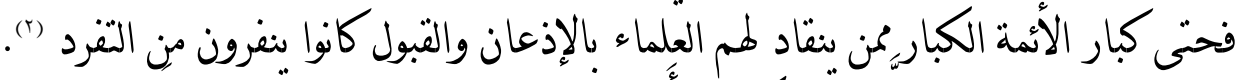

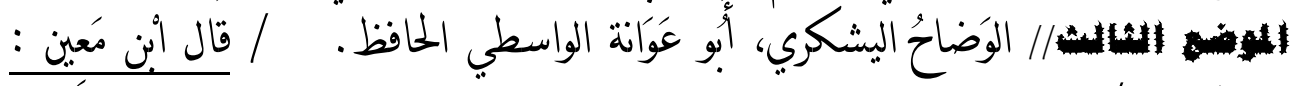

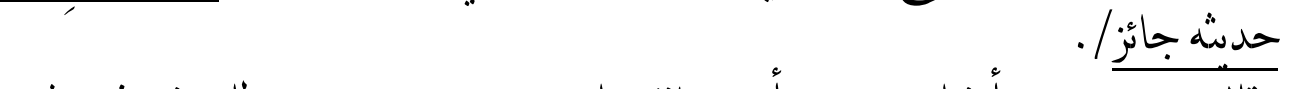

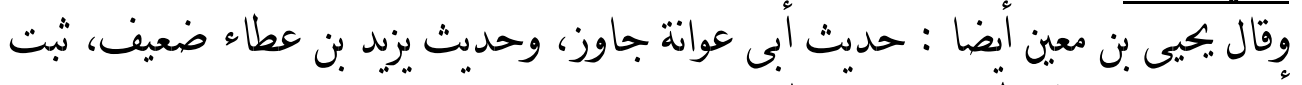

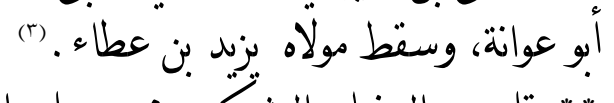

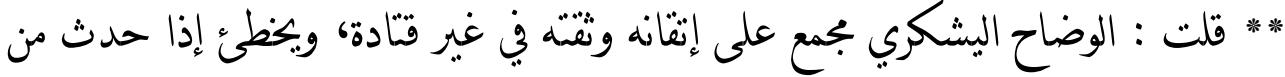
حفظه. (2)

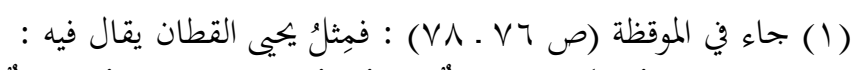

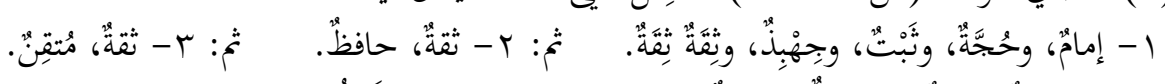

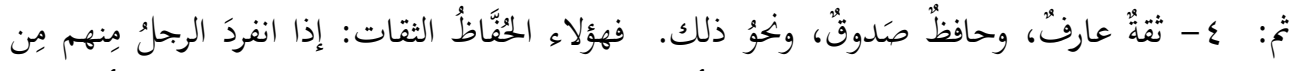

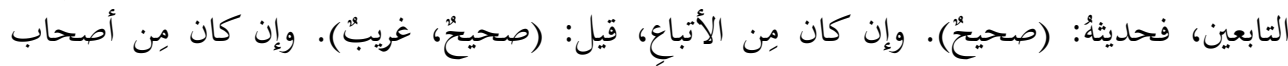

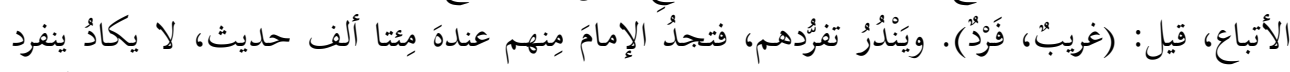

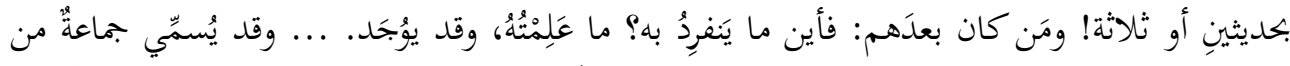

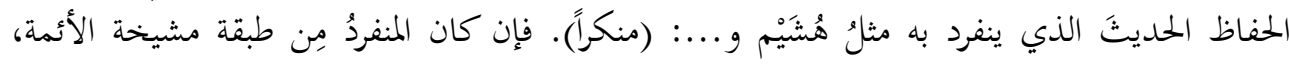

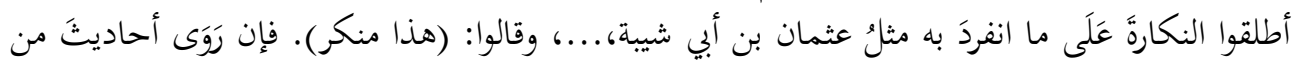

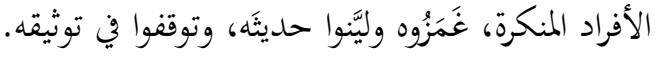

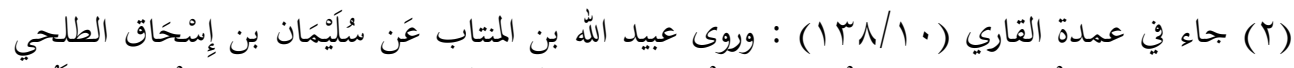

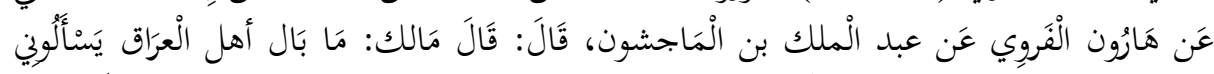

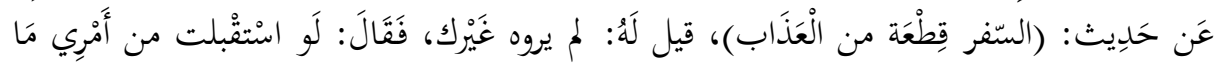

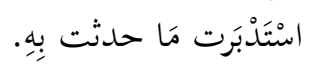

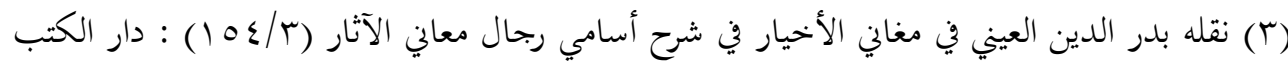
العلمية.

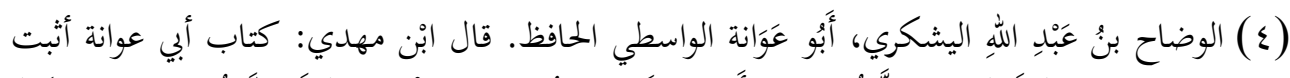

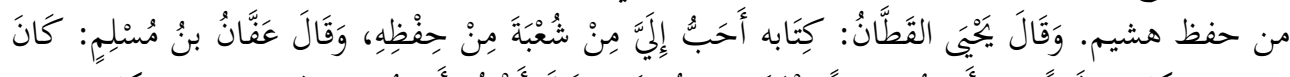

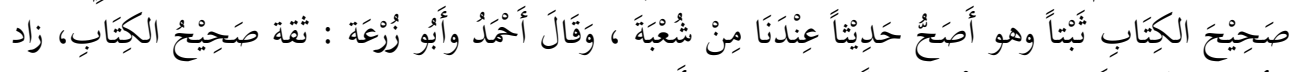

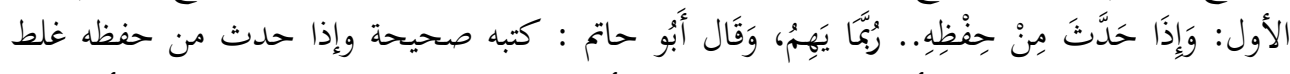

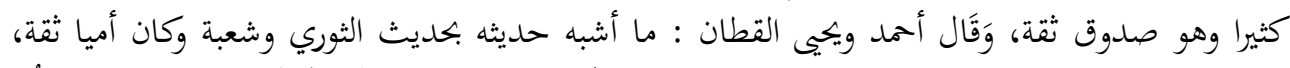

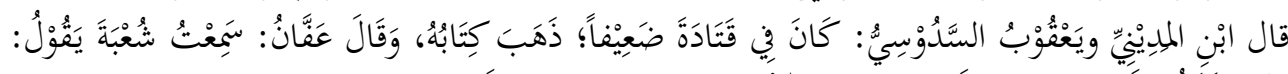

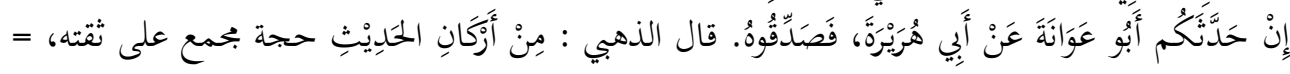



القول الحثيث في بيان مصطلح ( جائز الحديث) عند أئمة الحديث

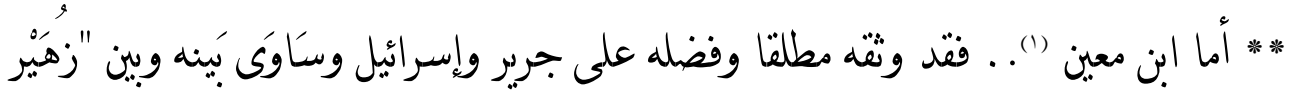

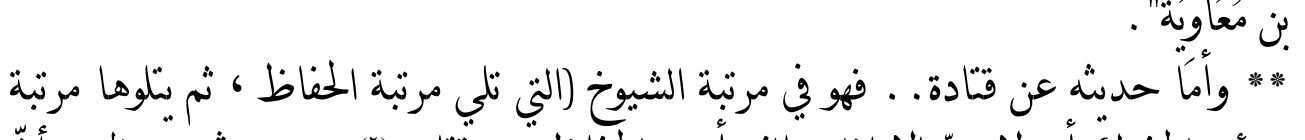

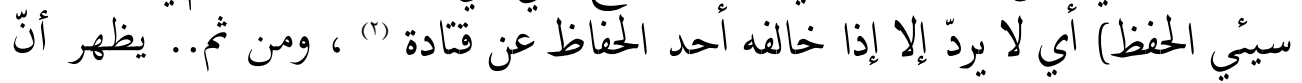
هذا نقاج خاص وليس جرحا مطلقا.

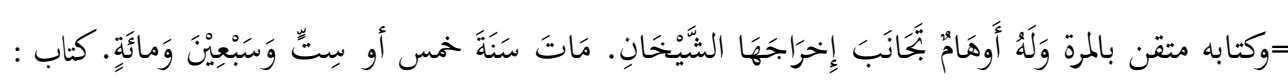

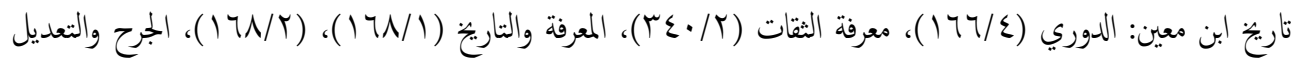
( ) (

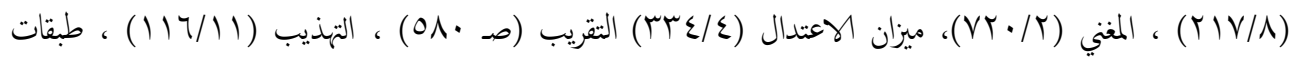
الحفاظ (صـ 7.1).

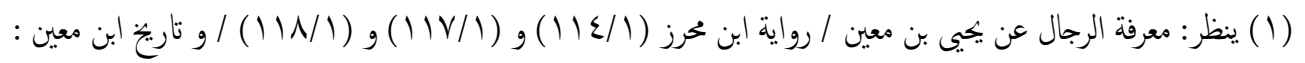

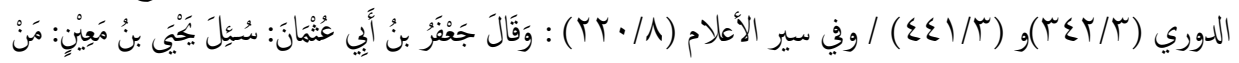

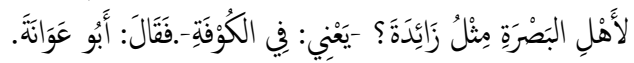

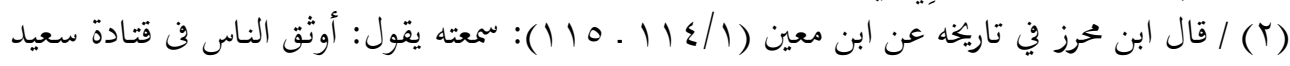

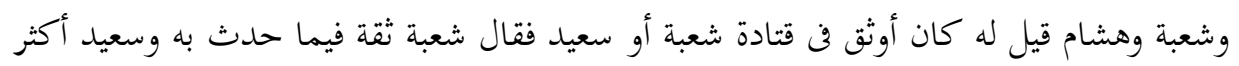

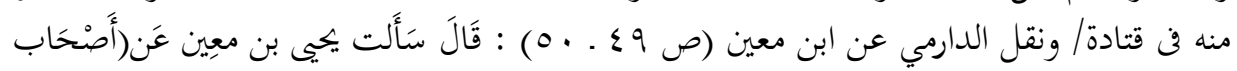

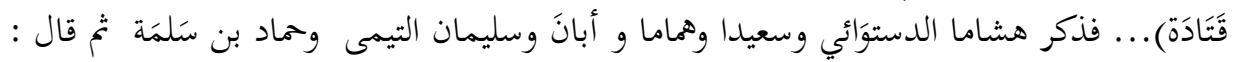

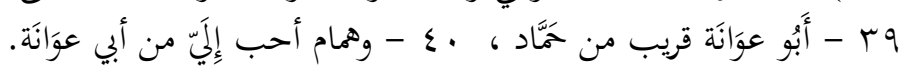

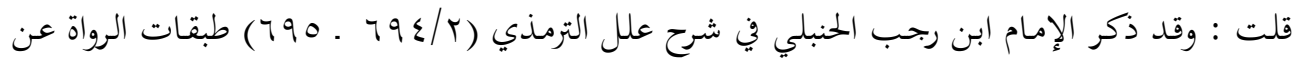

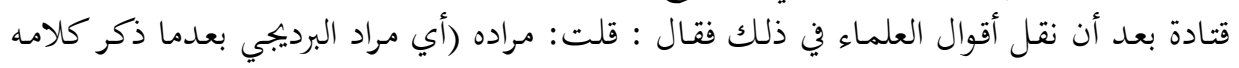

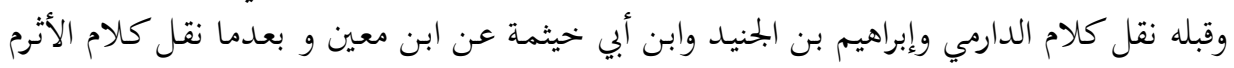

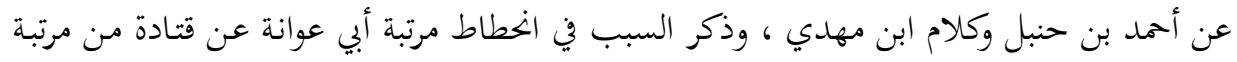

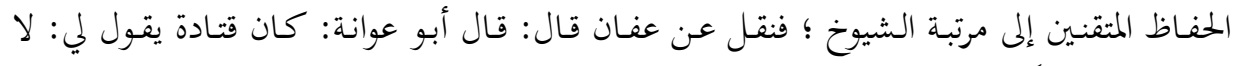

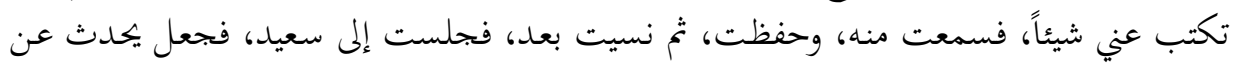

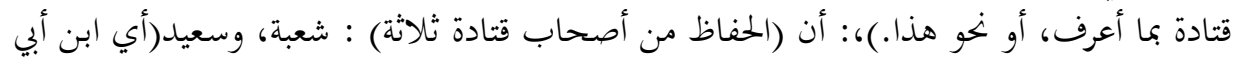

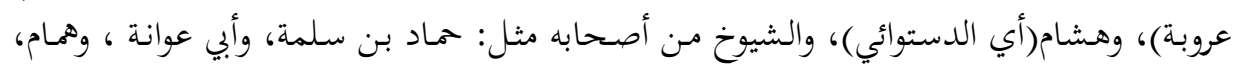
وأبان، ونوهم.

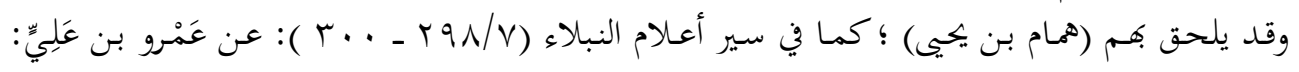
وعَلِيّ بن الممدِينِيِّ.

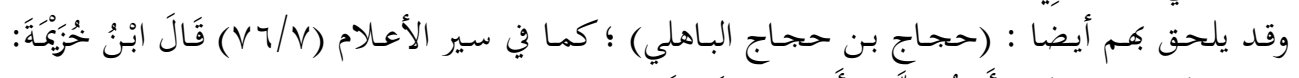

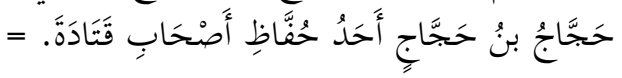



القول الحثيث في بيان مصطلح ( جائز الحديث) عند أئمة الحديث

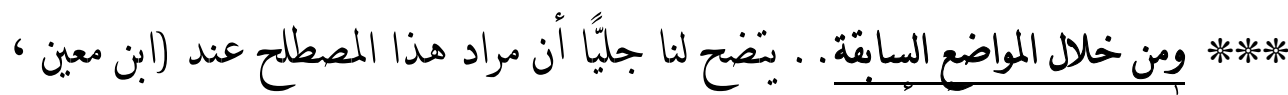

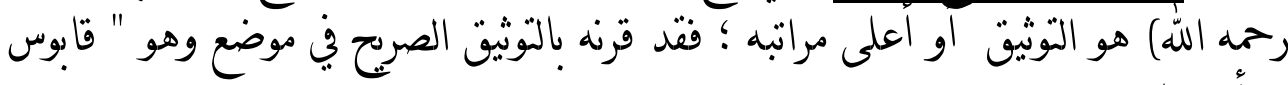
و أما الموضعان الأخيران.. فنتاء عطر وتفخيم لشأنهما ؛ فيكفي النظر

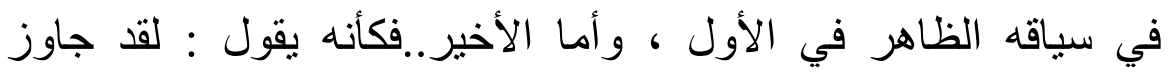

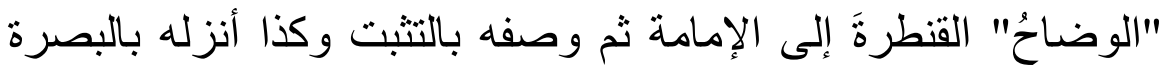
بمنزلة "زائدة" في إمامته للكوفة، فليتنبه لهذا ، و الله أعلم. 橉粮

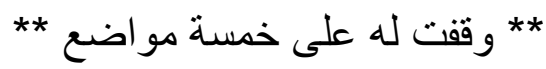

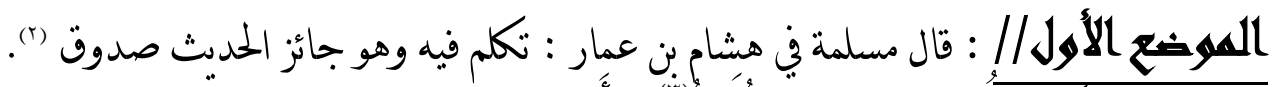

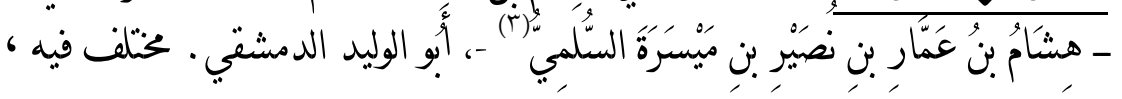

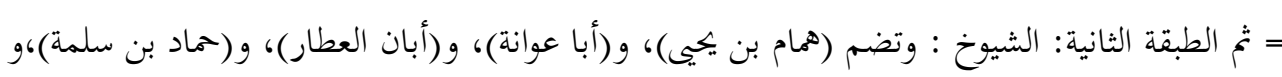

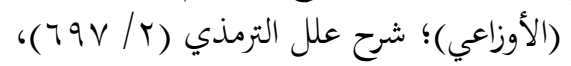

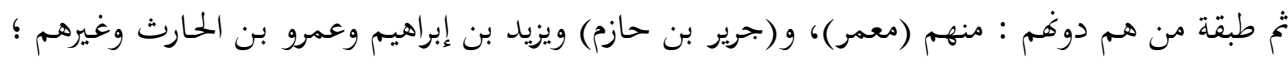

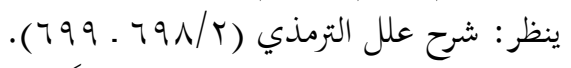

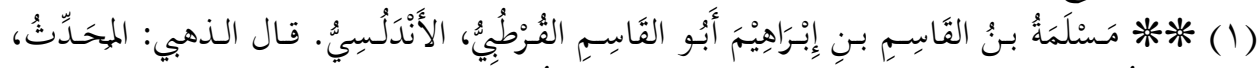

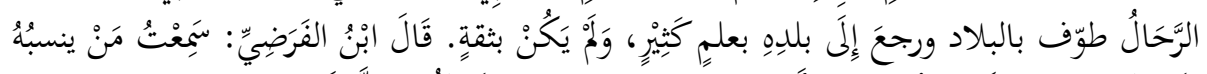

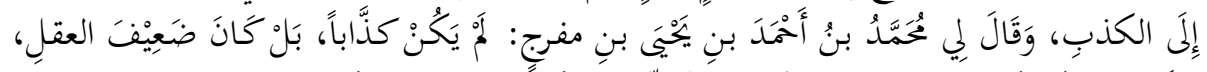

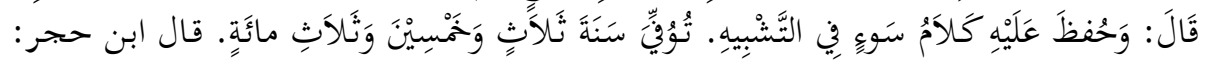

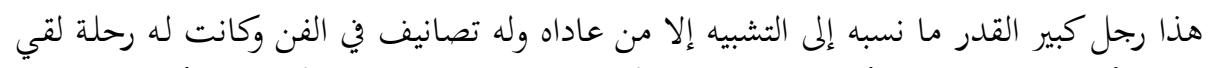

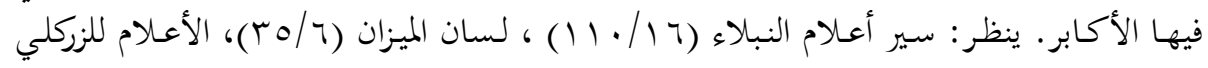

$$
\text { . (Y T } \leqslant / V)
$$

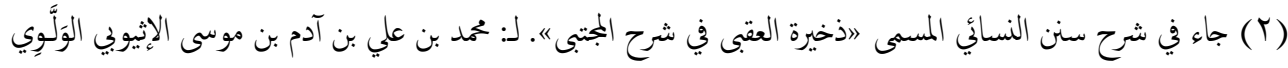

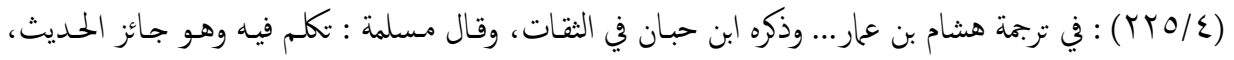

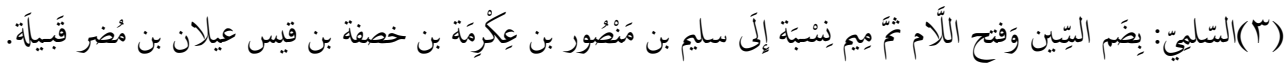

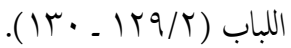




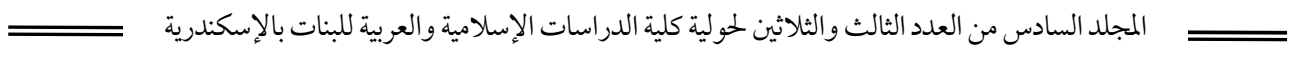

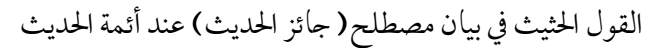 \\ وَقال أحمد : طياش خفيف) (1).}

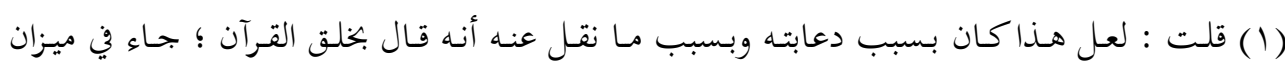

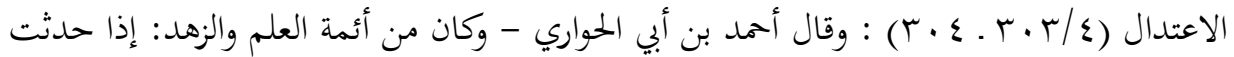

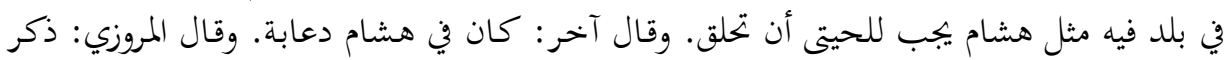

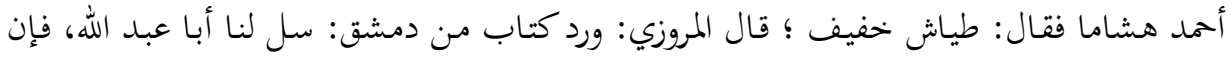

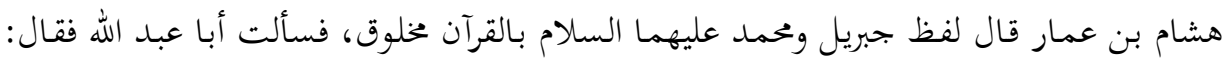

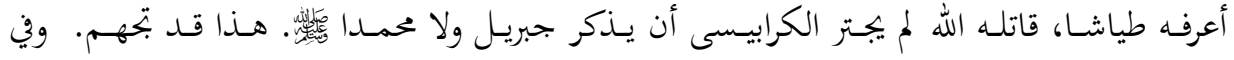

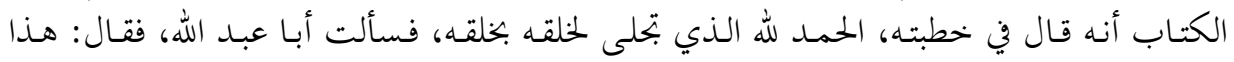

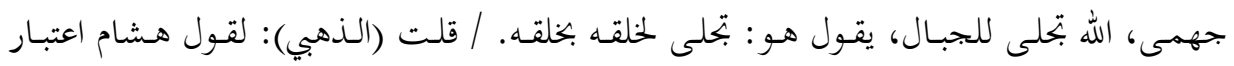

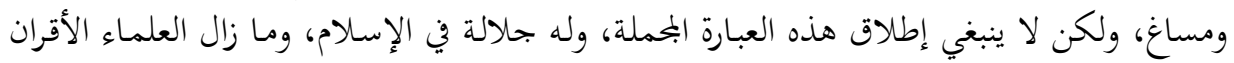

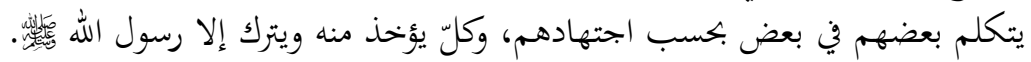

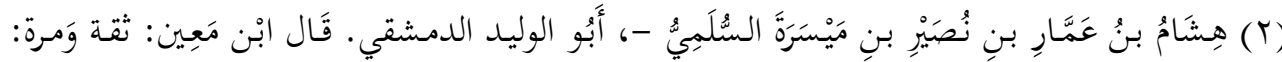

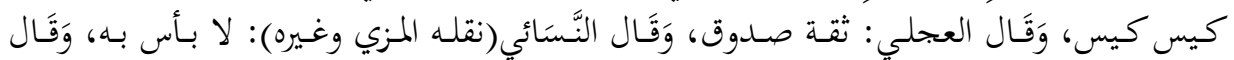

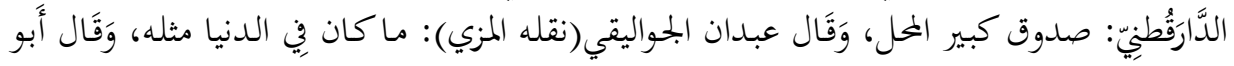

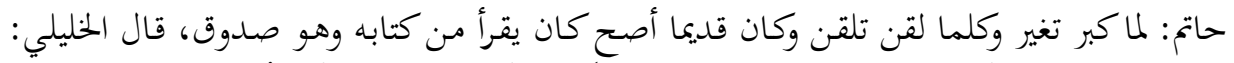

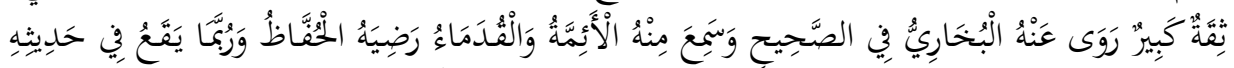

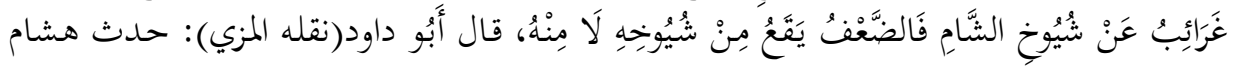

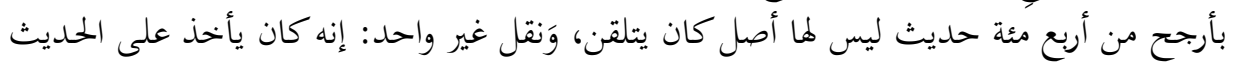

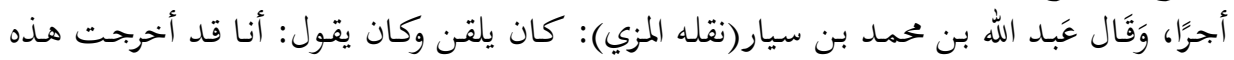

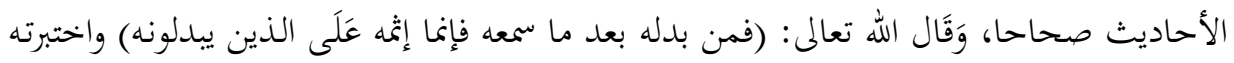

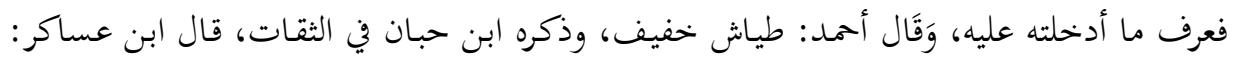

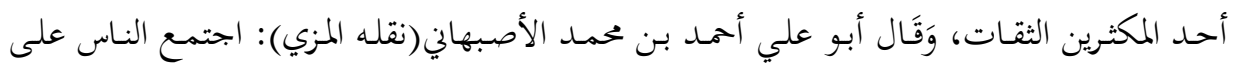

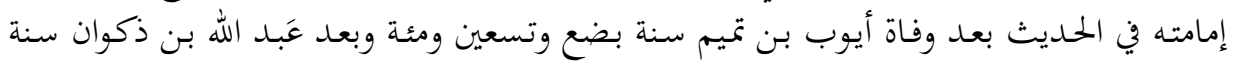

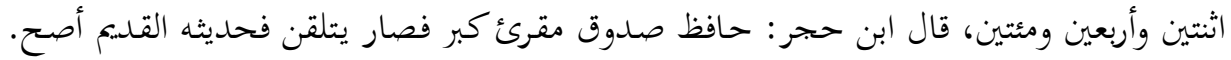

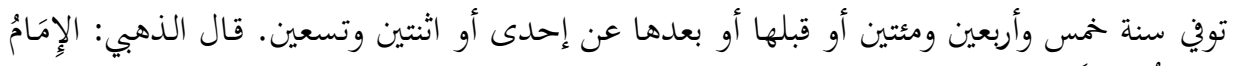

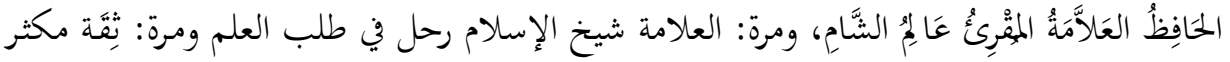

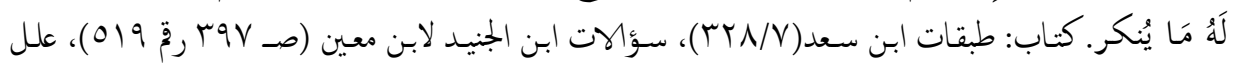

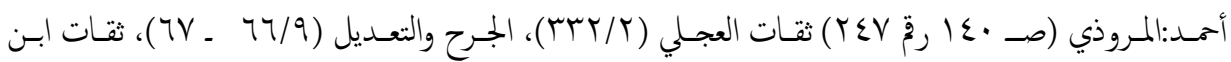

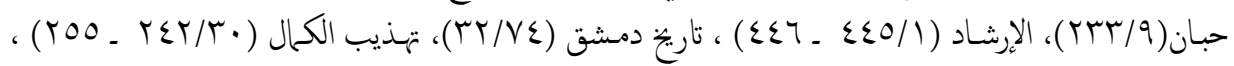

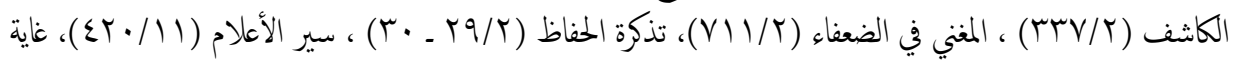

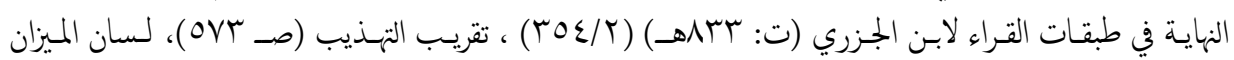

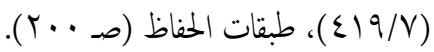




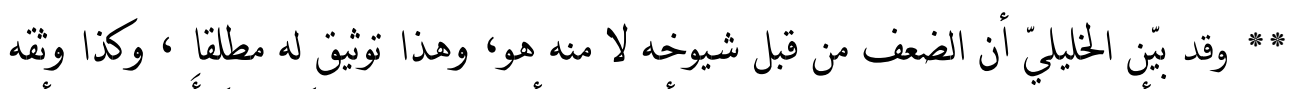

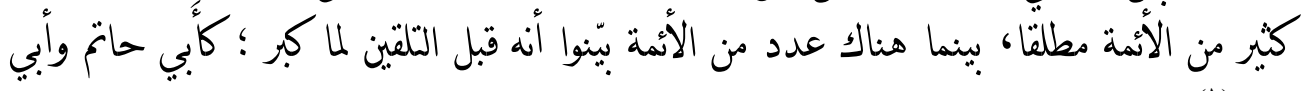

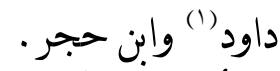

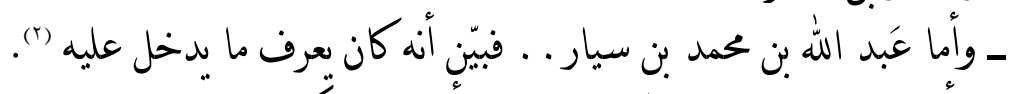

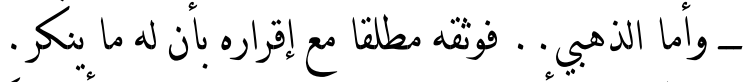

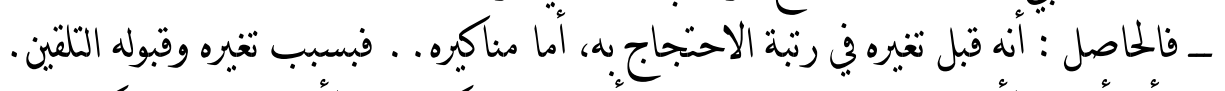

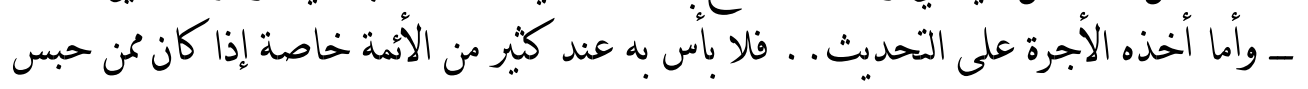
قنسه على الطلب والرحلة ووقته لطلاب العلم.

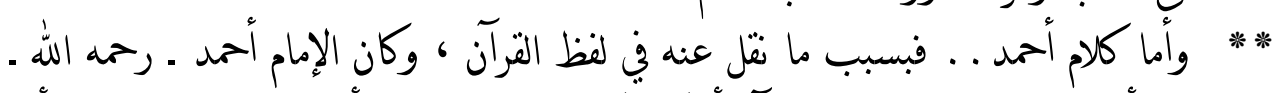

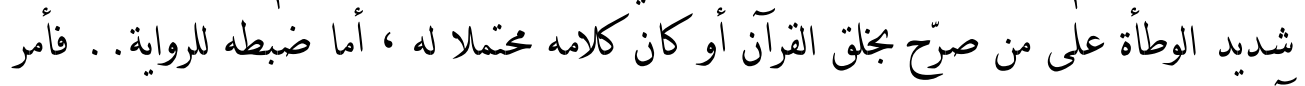

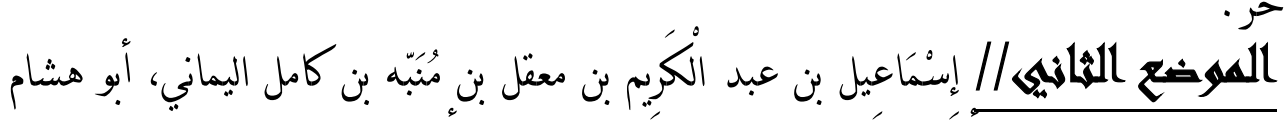

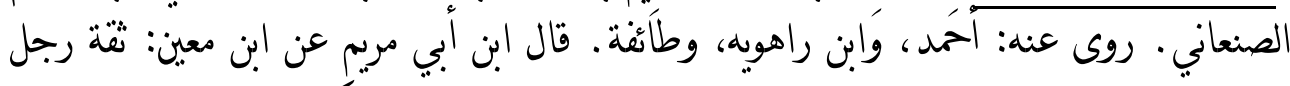

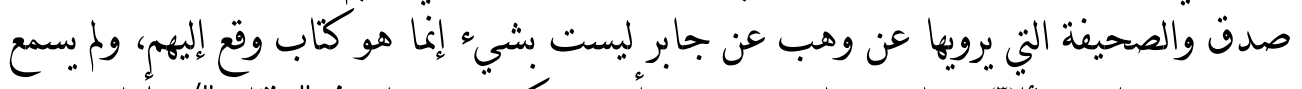

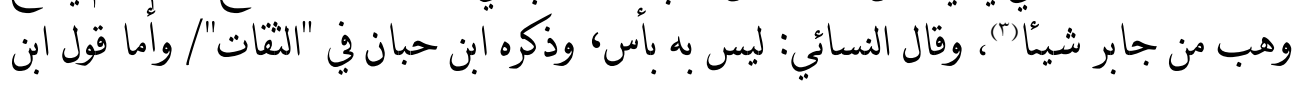

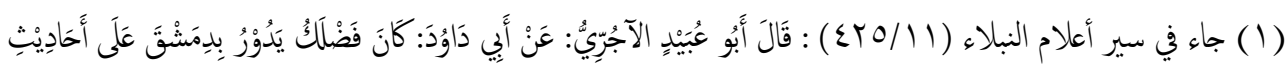

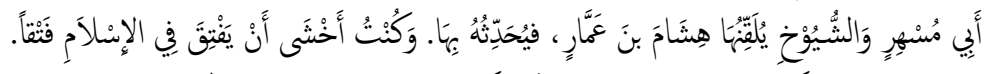

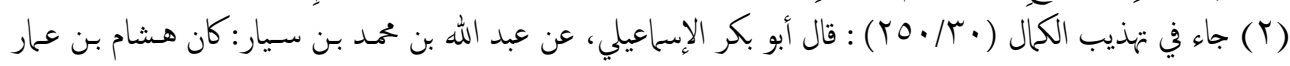

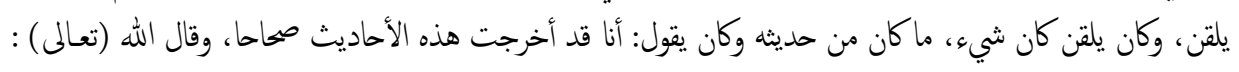

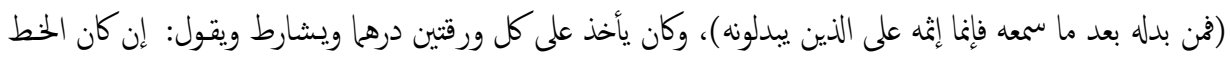

$$
\text { دقيقا فليس بيني وبين الدقيق عمل. }
$$

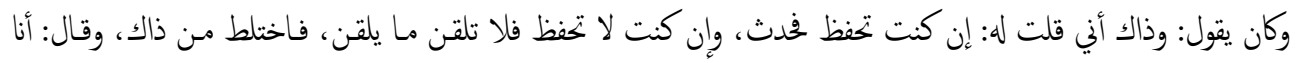
أعرف هذه الأحاديث. ثم قال لي بعد ساعة: إن كنت تشتهي أن تعلم فأدخل إسنادا في شيء، فتنقدت الأسانيد التي فيها قليل اضطراب، فجعلت أسأله عنها فكلان يمر فيها يعرفها.

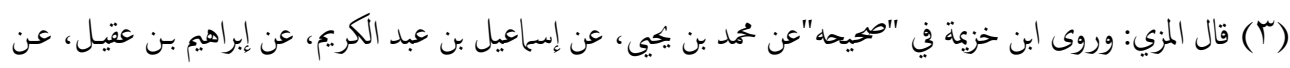

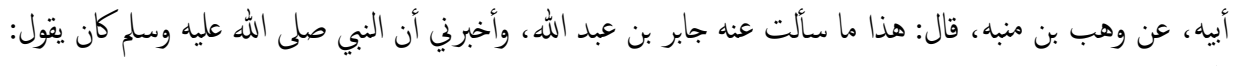

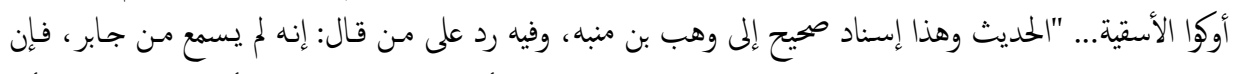

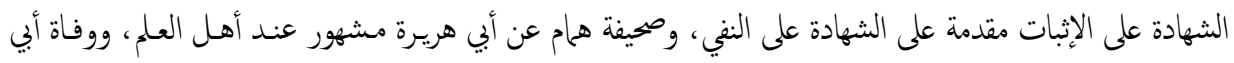

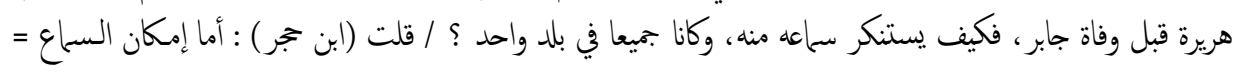




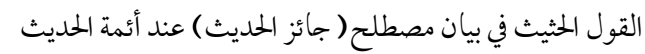

القطان الفاسي : لا بعرف فمردود عليه"،//وقال مسلمة بن قاسم(قُله ابن حجر): "جائز

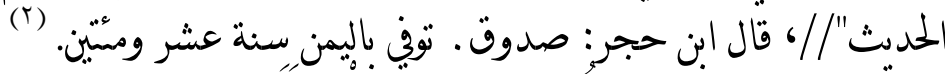

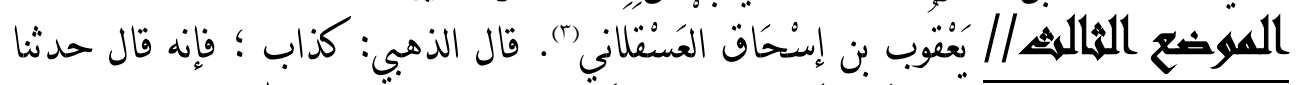

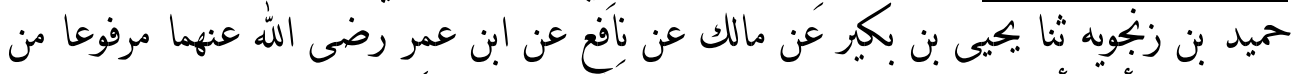

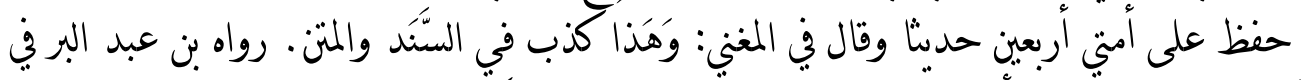

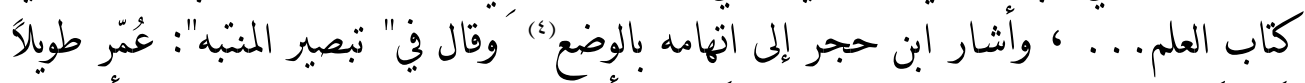

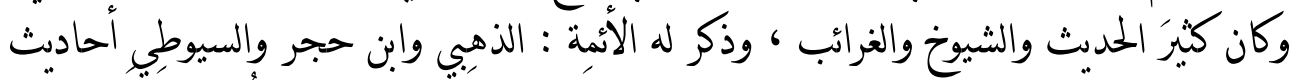

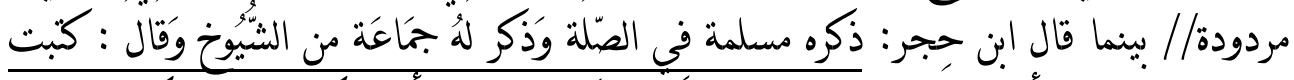

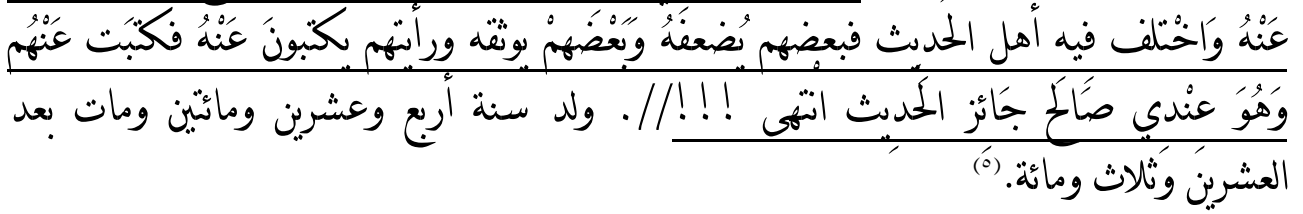

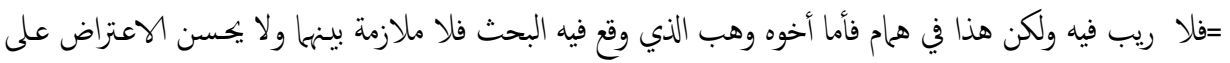

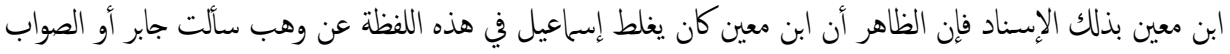
عنده عن جابر - والله أعلم-.

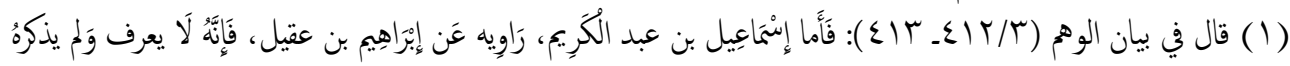

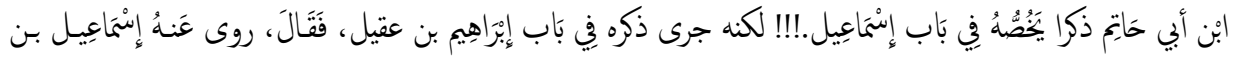

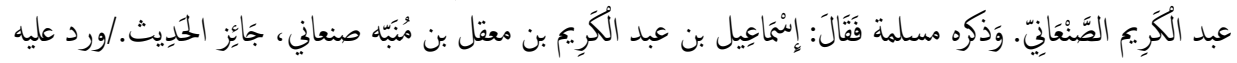

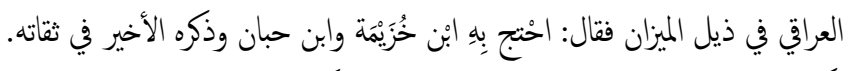

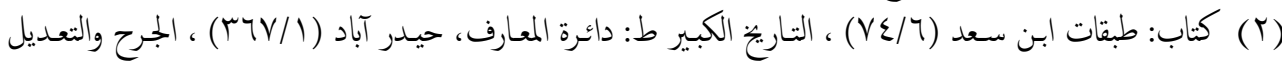

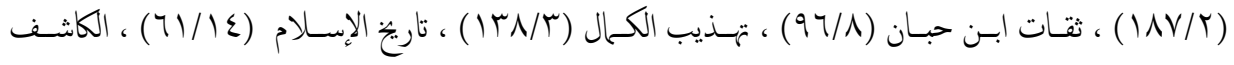

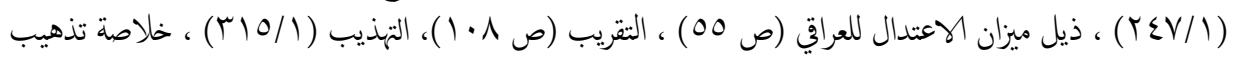

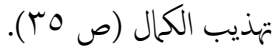
(T) قال ابن ججر في اللسان: يعقوب بن إسحاق بن إبراهيم بن يزيد بن حجر "ابن حجر" بفتح الحاء والجيم كذا في نسخة من كتاب العلم لابن عمر النمري.

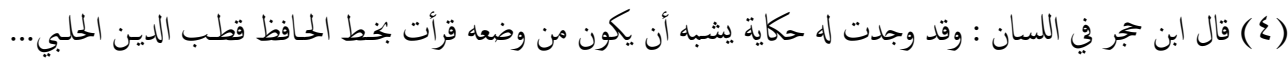

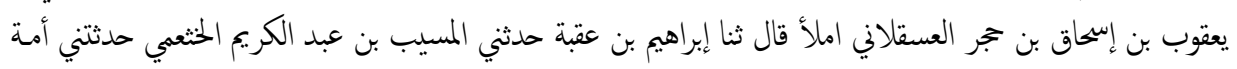

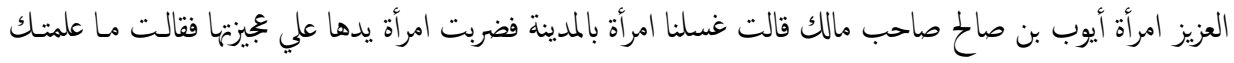

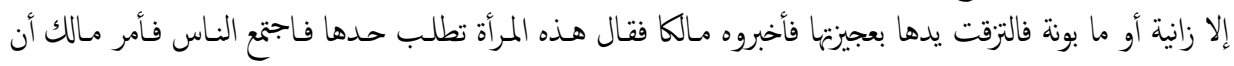

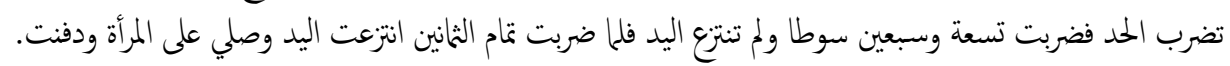

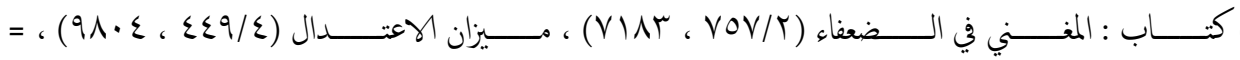




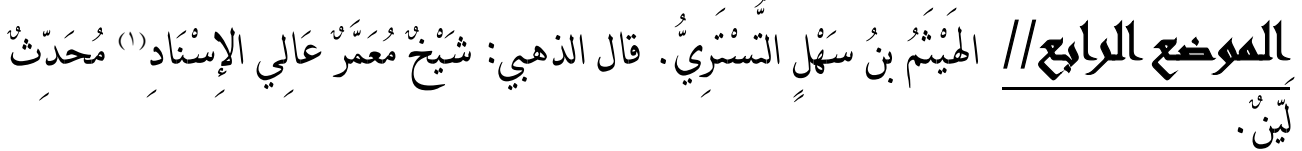

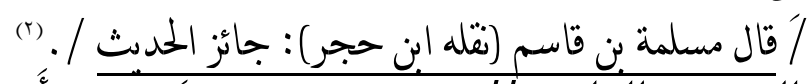

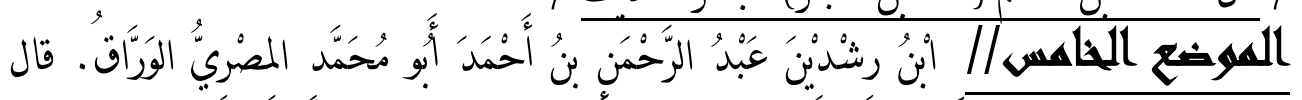

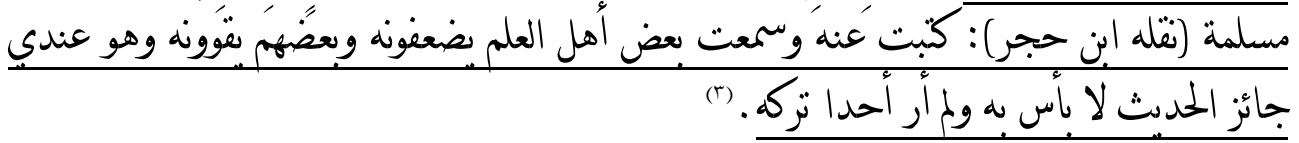

\section{:}

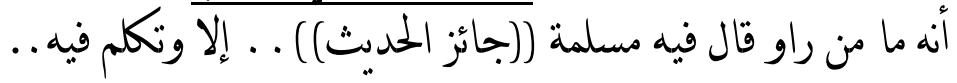

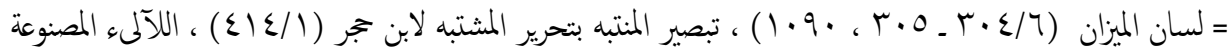

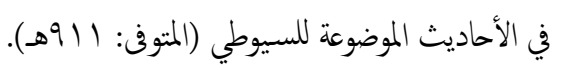

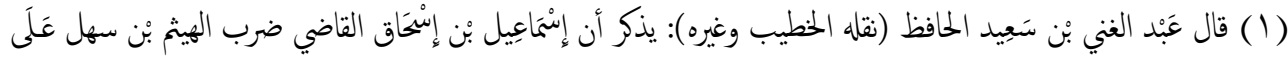

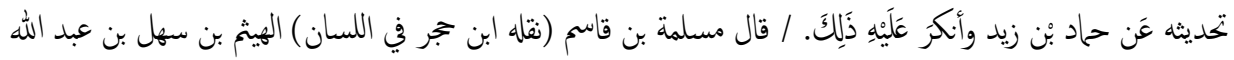

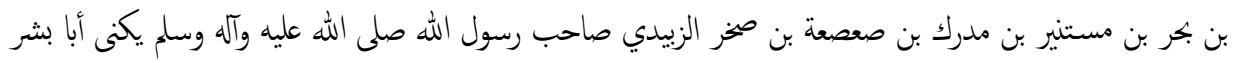

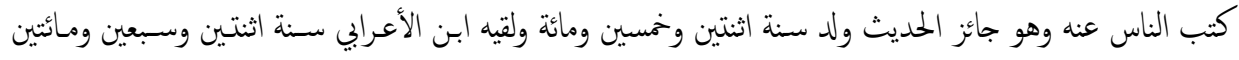

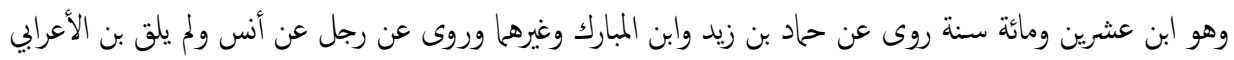

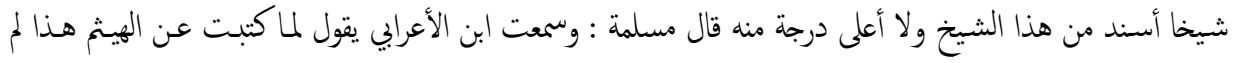

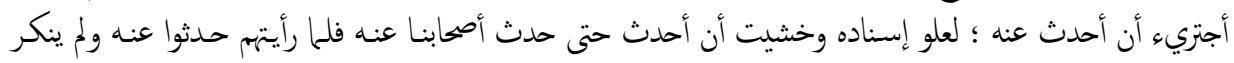

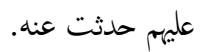

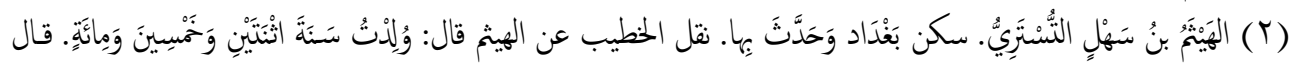

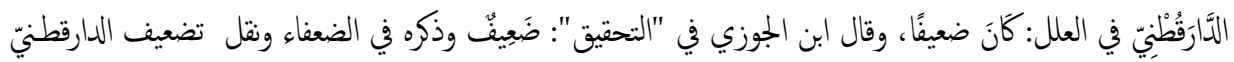

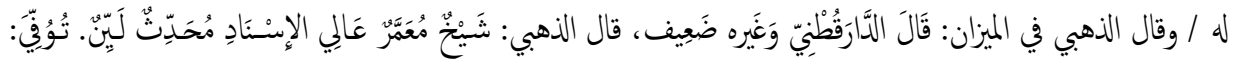

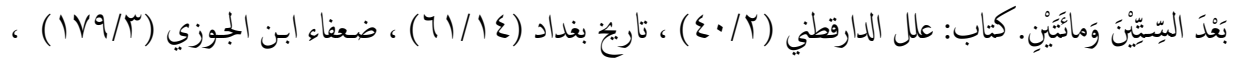

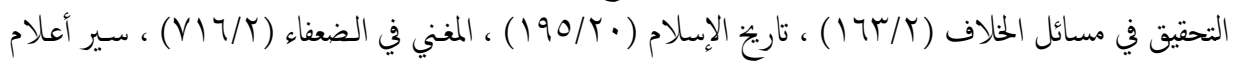

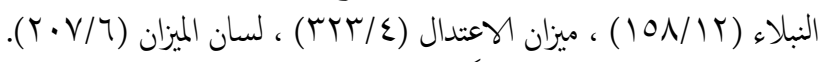

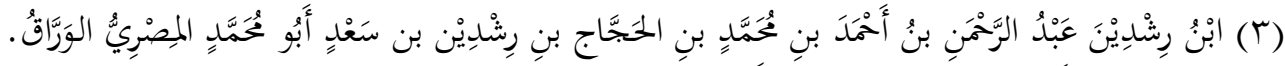

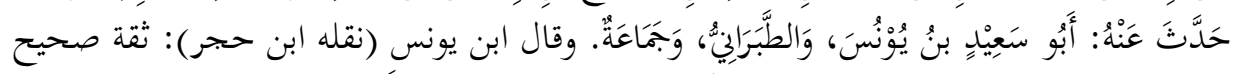

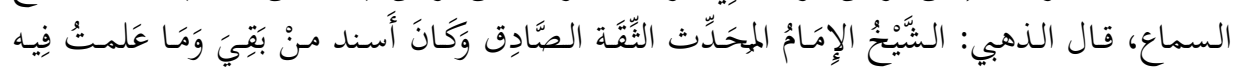

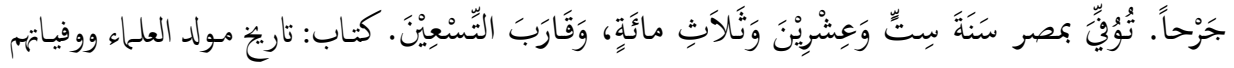

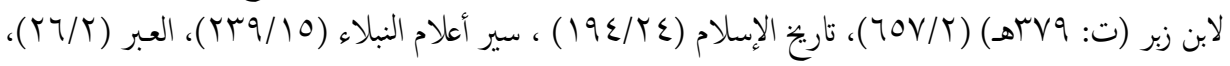

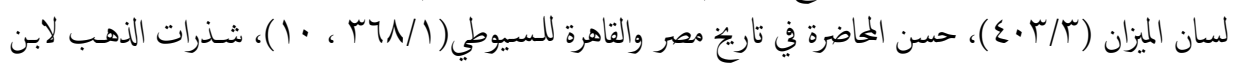




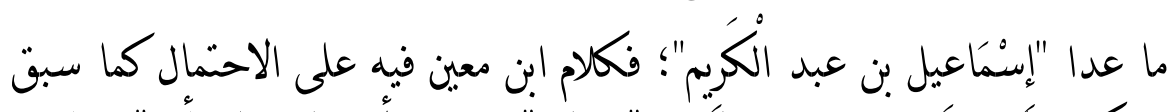

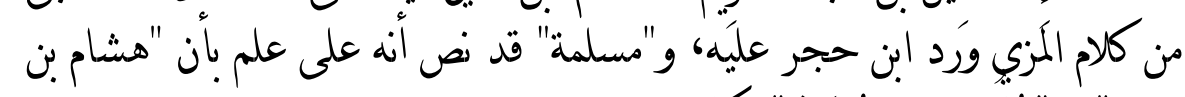

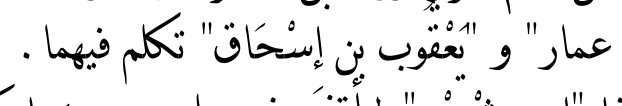

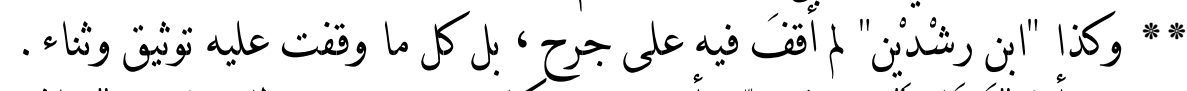

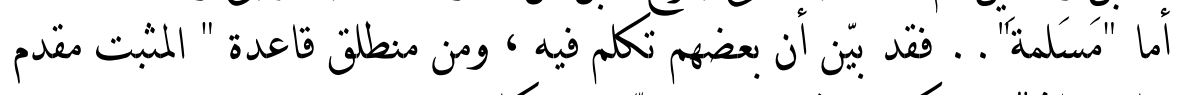

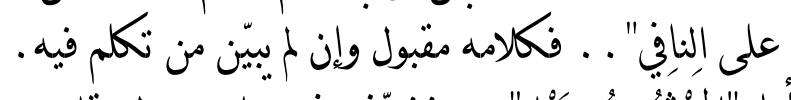

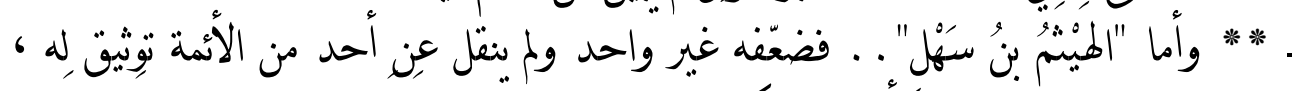

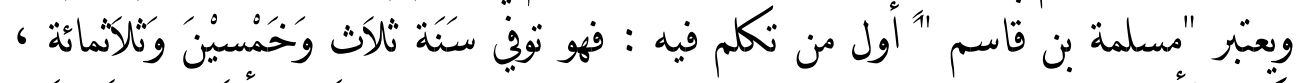

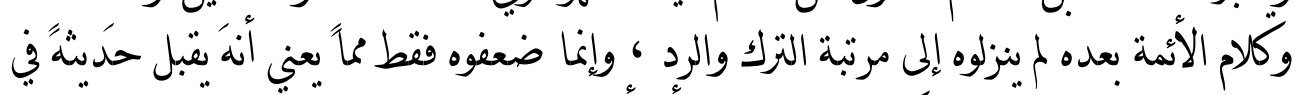

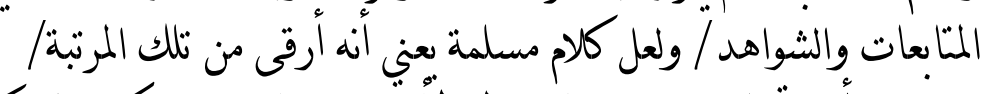

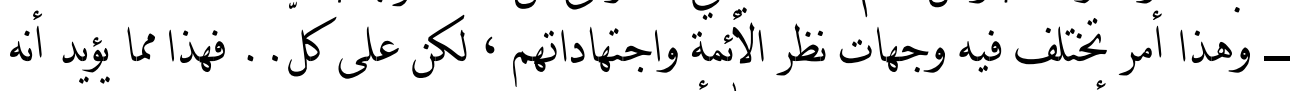

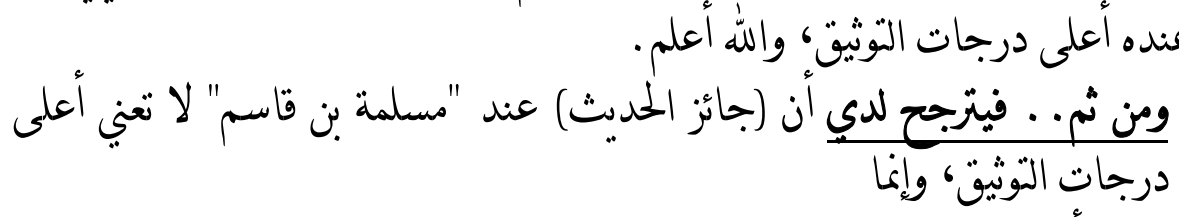

$$
\text { (أ) التوسط في أمر الراوي. }
$$

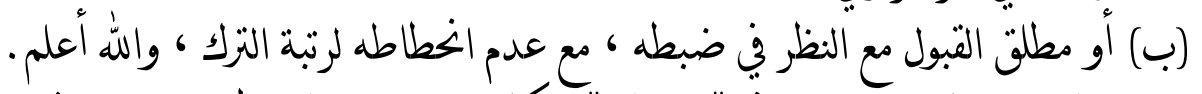

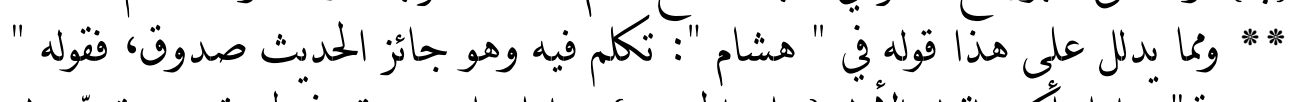

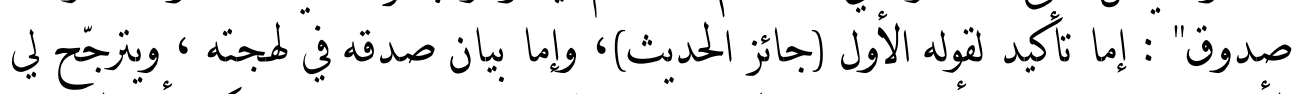

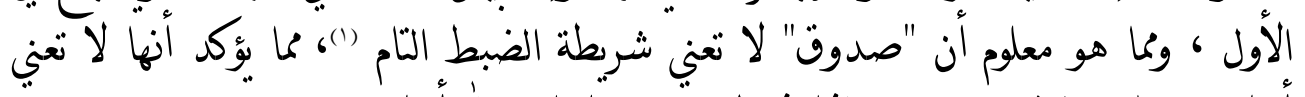

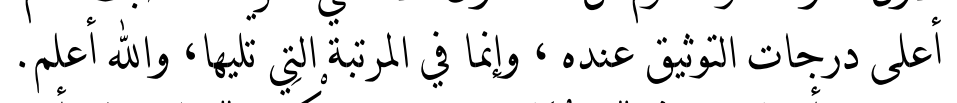

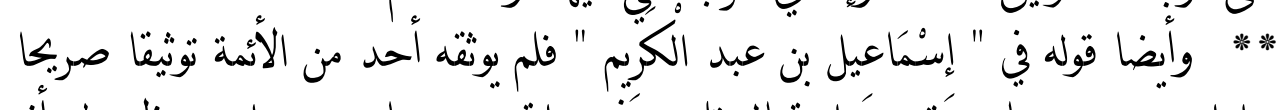

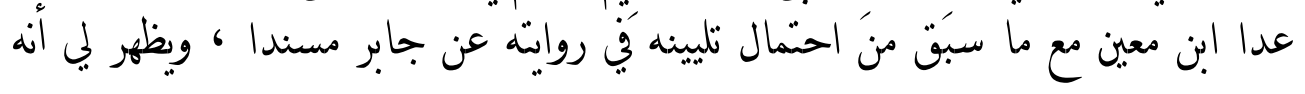

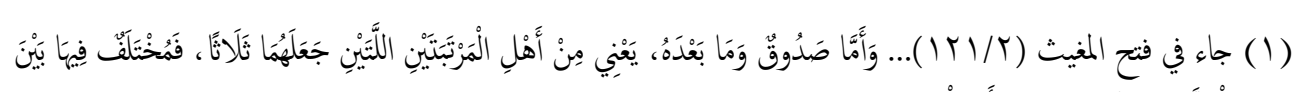

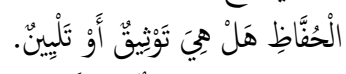

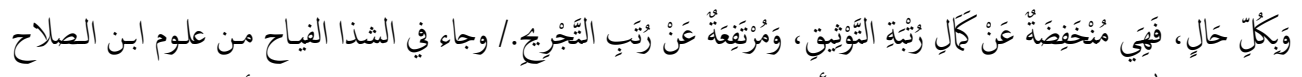

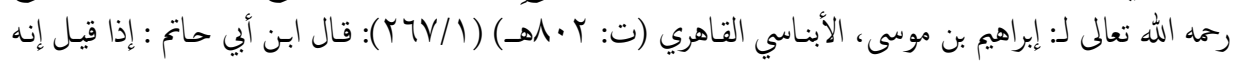

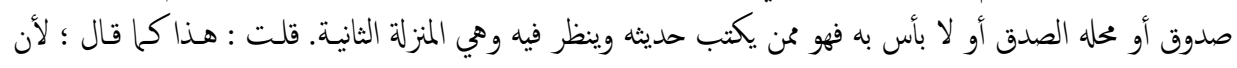

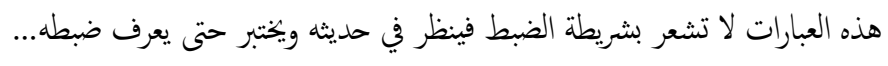




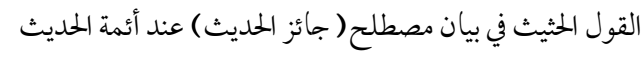

توسط في توثيقه ؛ فقد توسط فيه النسائي وذكره ان حبان في "الثقات" ، وككا نقل الذهبي

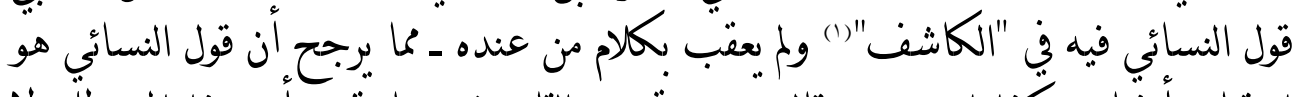

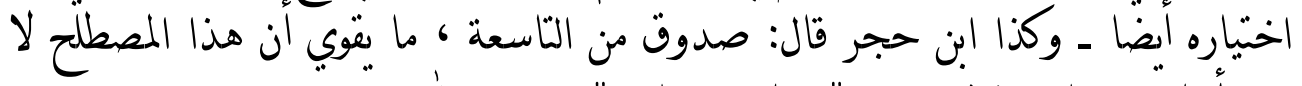

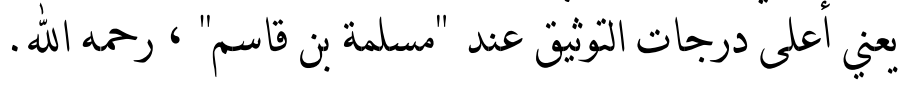

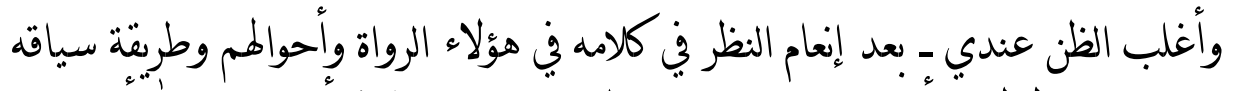

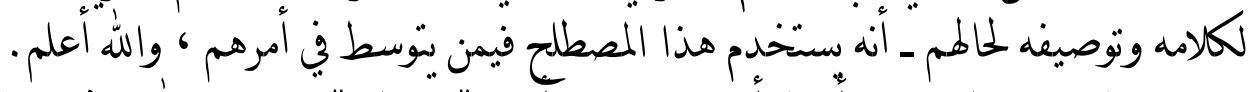

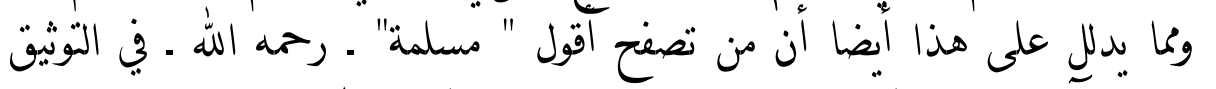

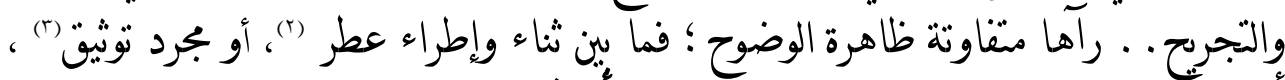

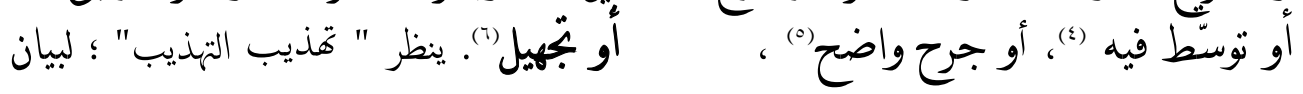

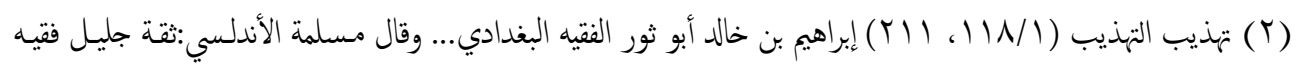

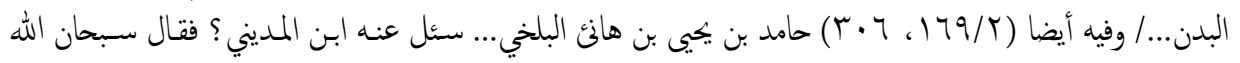

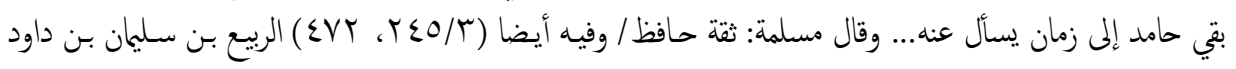

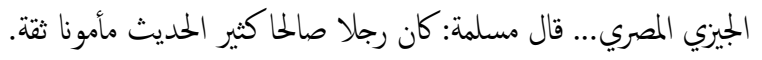

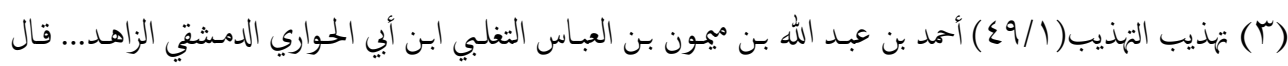

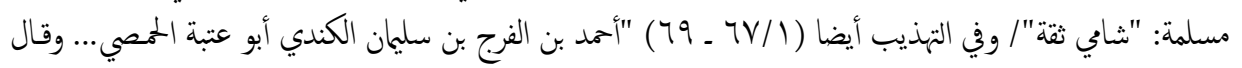

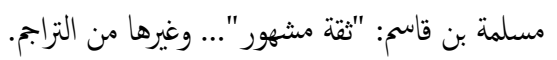

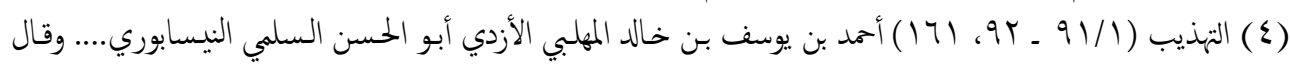

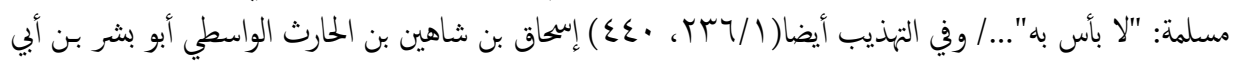

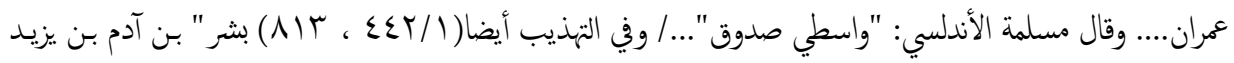

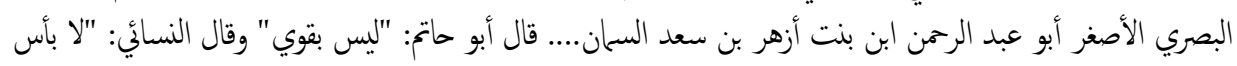

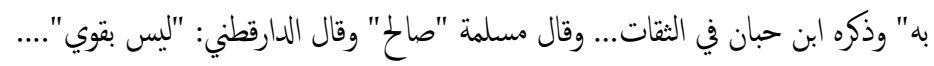

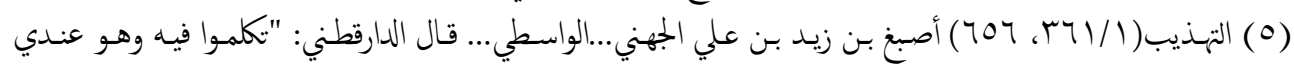

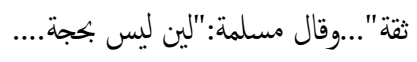

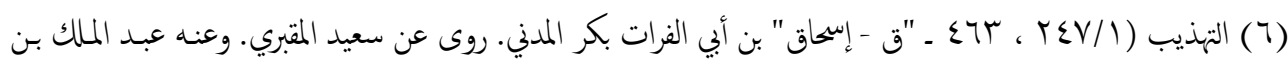

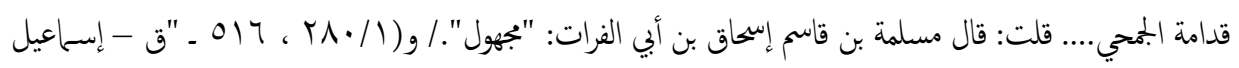
بن إبراهيم البالسي... "قال مسلمة في الصلة بهول". 
=

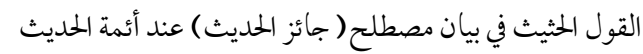

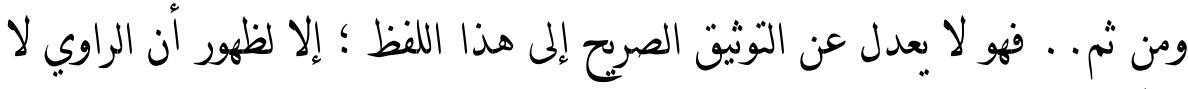

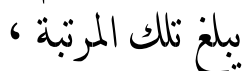

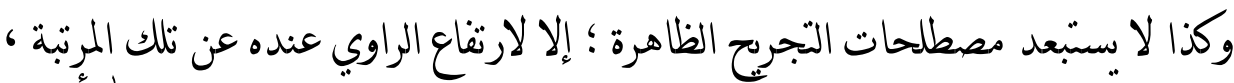

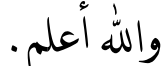




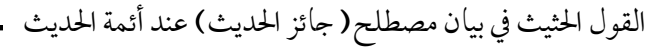

洸橉 (1) ثالثا : الإمام أبو داود السجستان:

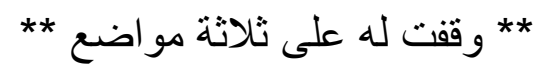

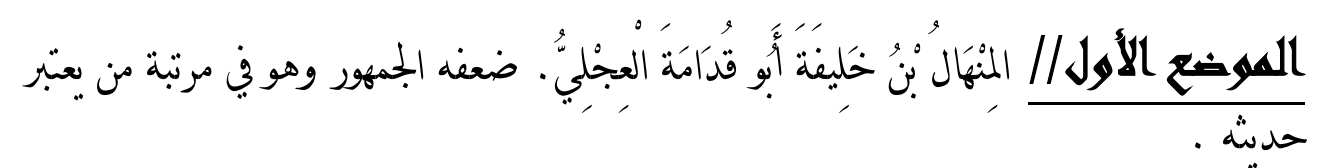

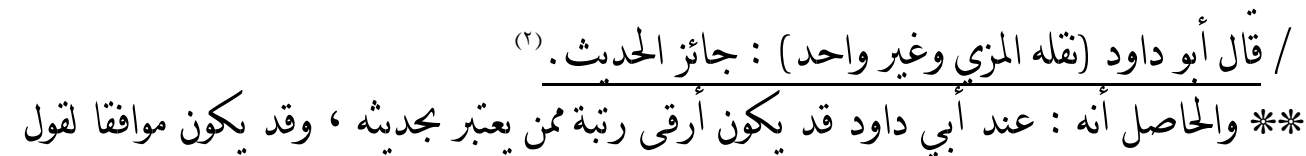

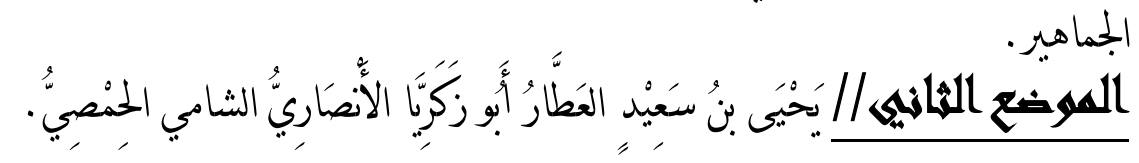

(1)

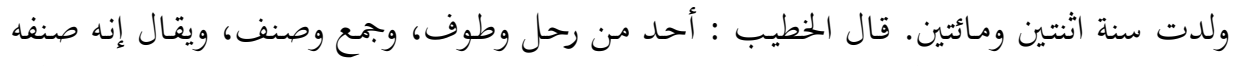

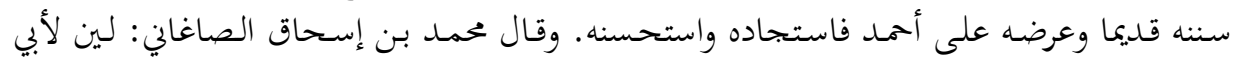

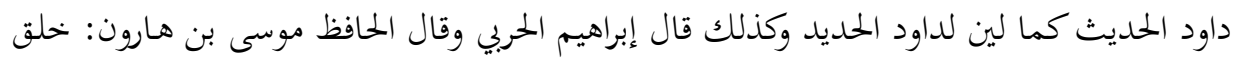

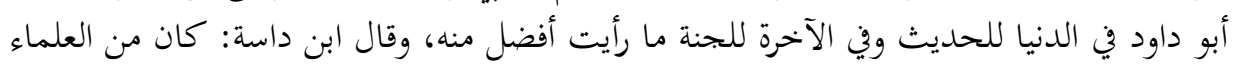

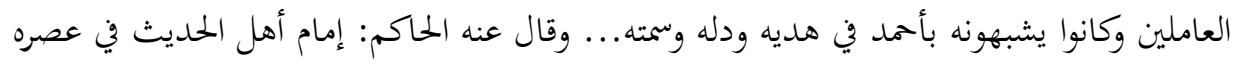

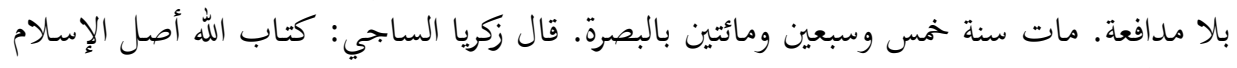

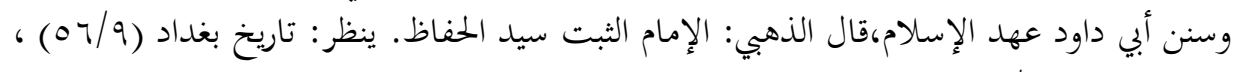

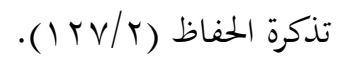

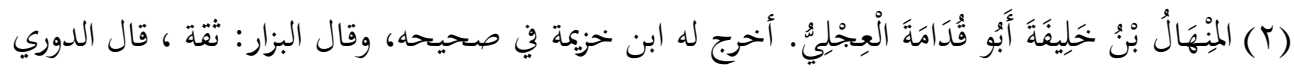

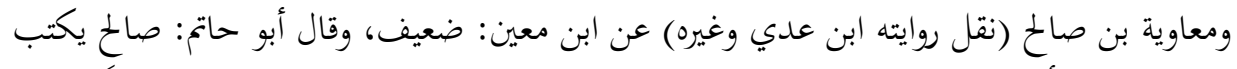

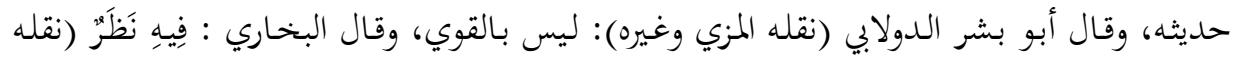

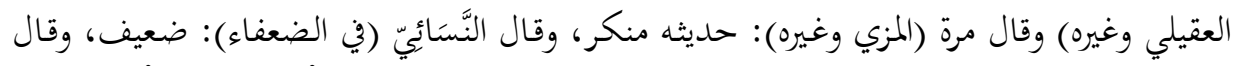

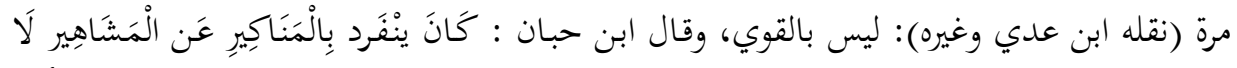

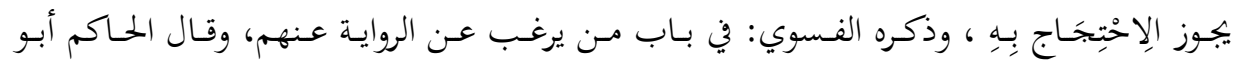

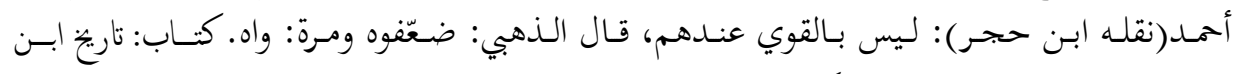

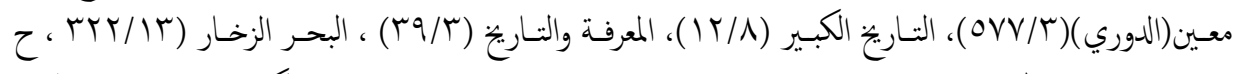

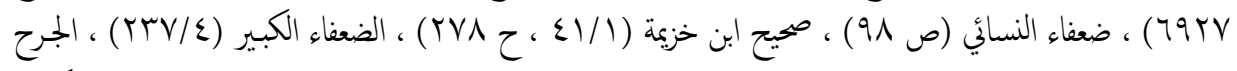

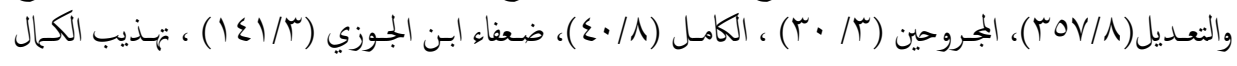

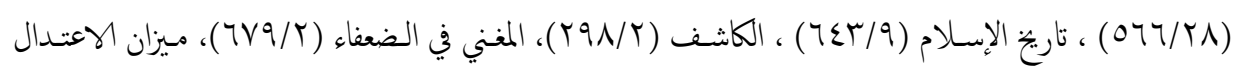

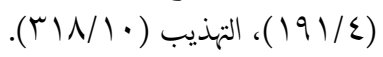




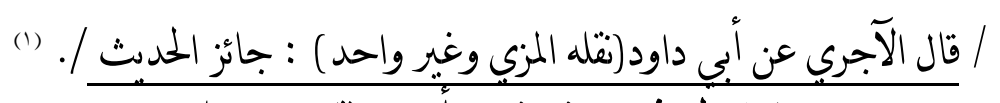
.

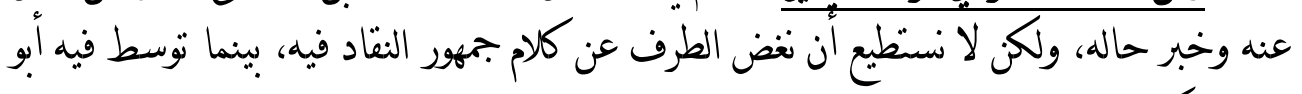

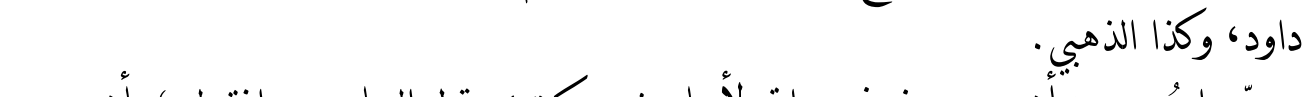

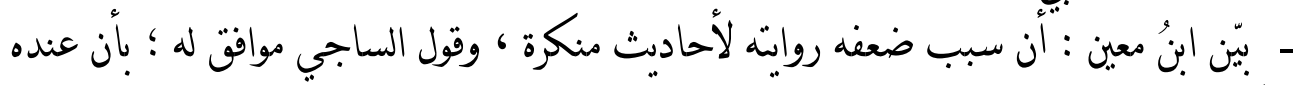
مناكير.

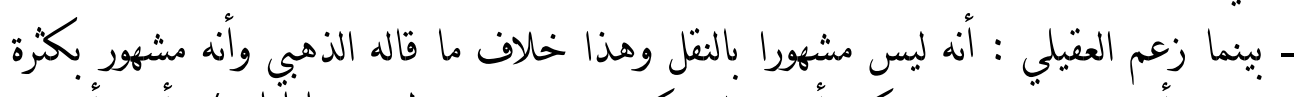

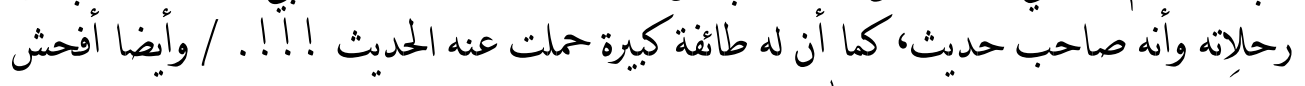

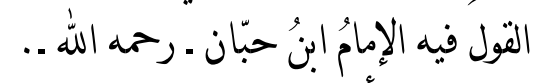

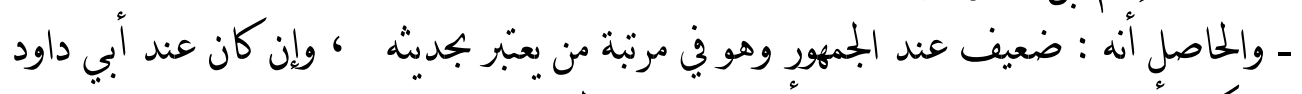

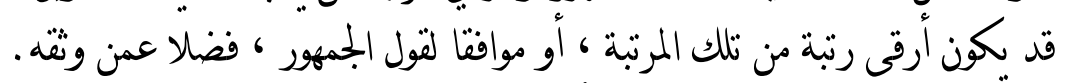

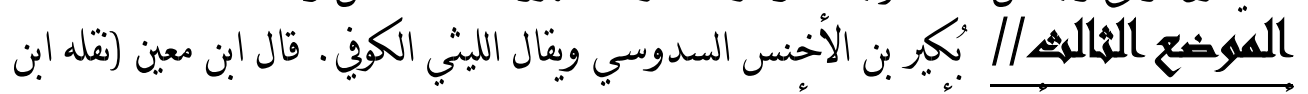

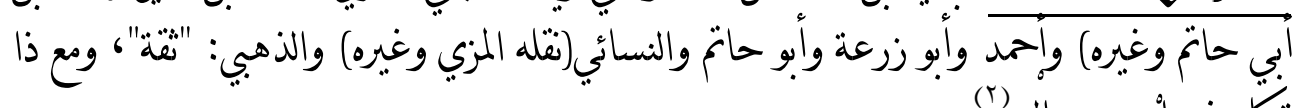

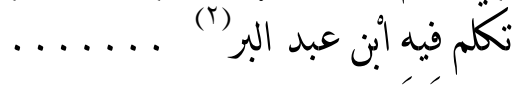

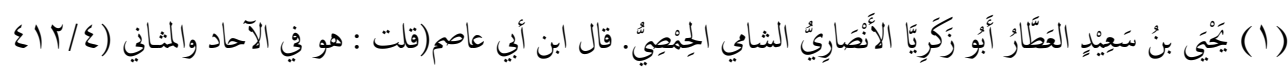

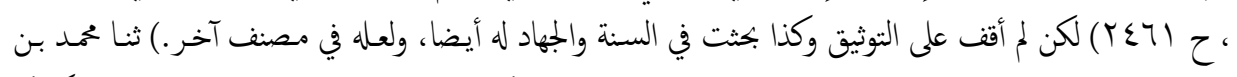

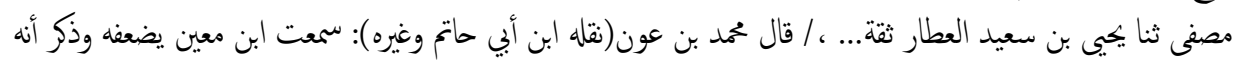

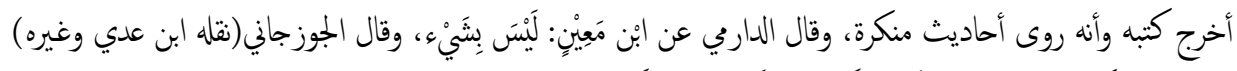

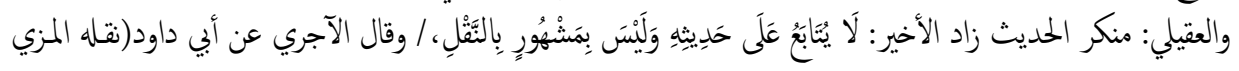

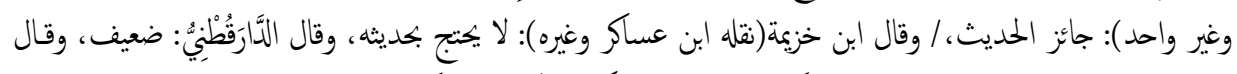

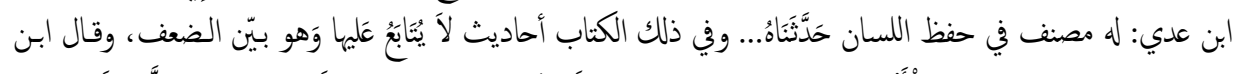

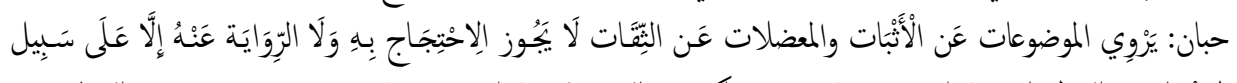

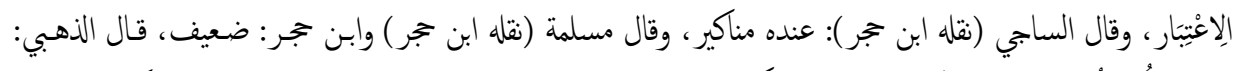

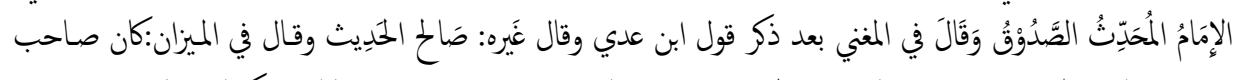

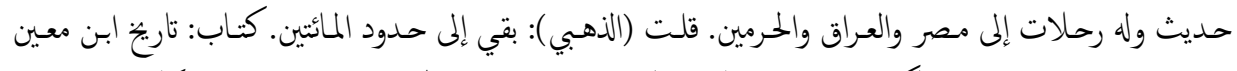

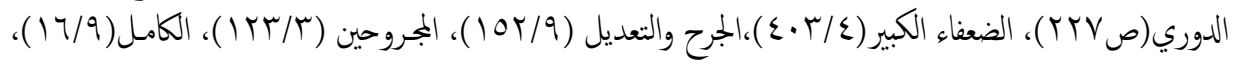

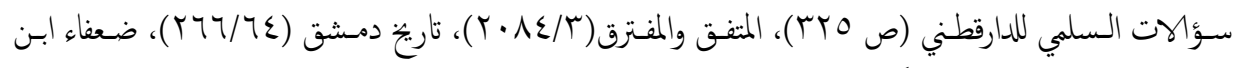

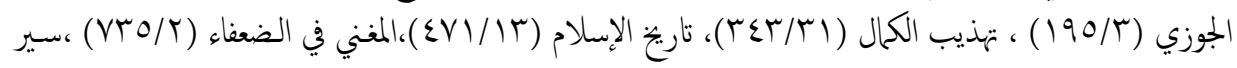

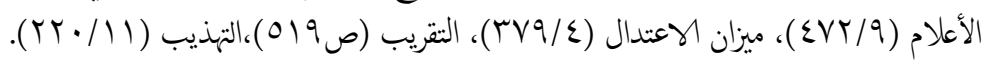

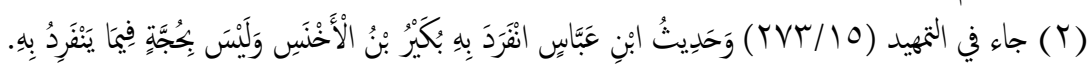



القول الحثيث في بيان مصطلح ( جائز الحديث) عند أئمة الحديث

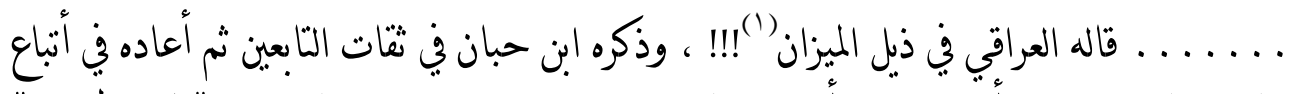

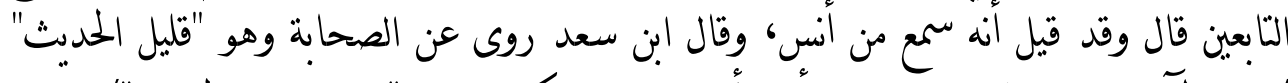

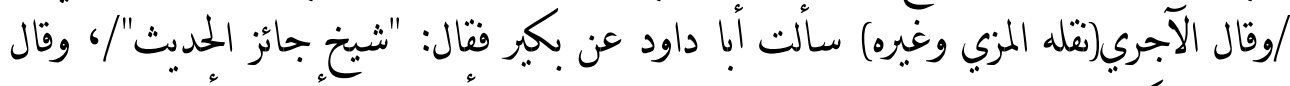

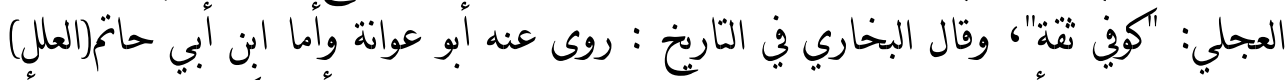

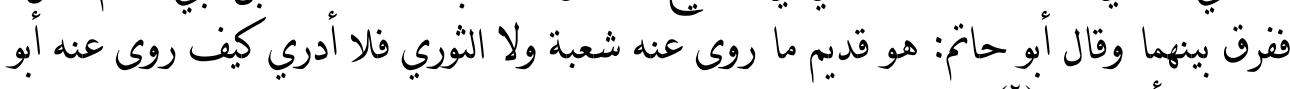
عوانة ولا أن لقيه.

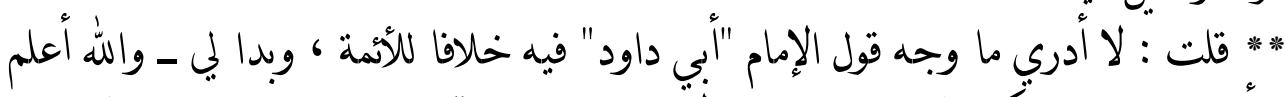

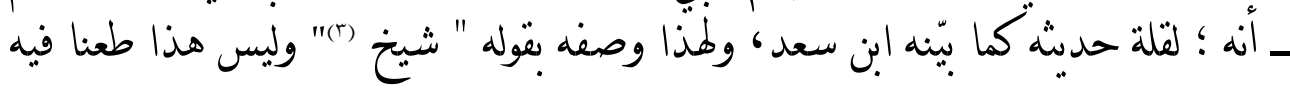

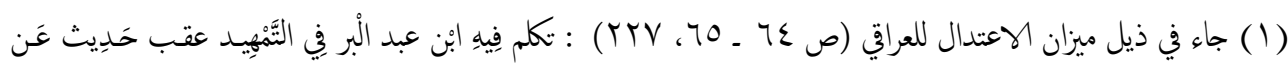

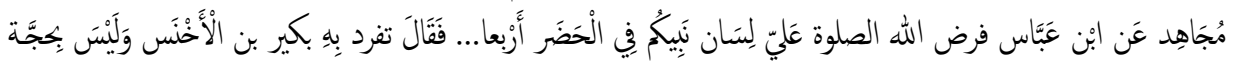

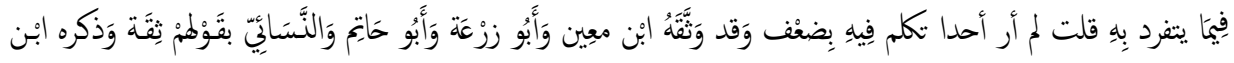
حبَان في الثِّقَّات.

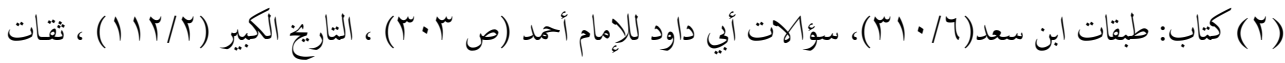

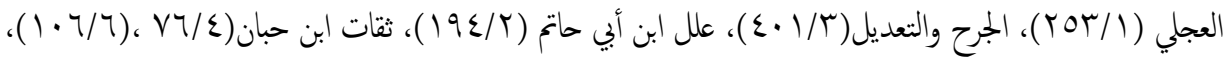

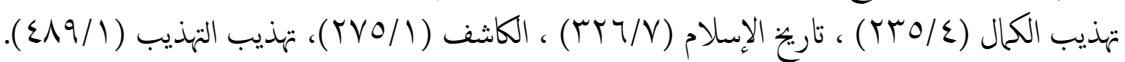

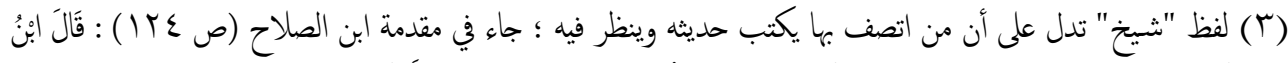

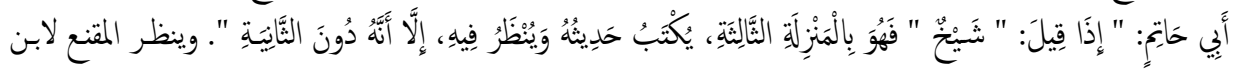

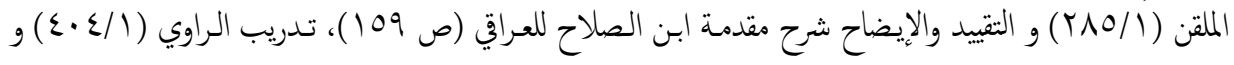

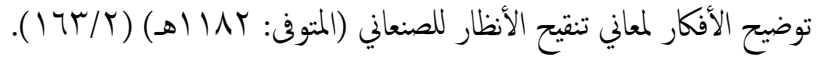

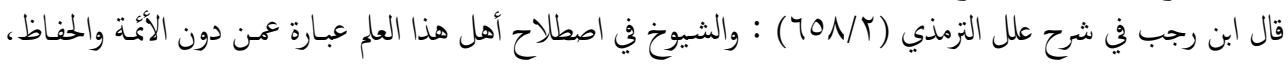
وقد يكون فيهم الثقة وغيره.

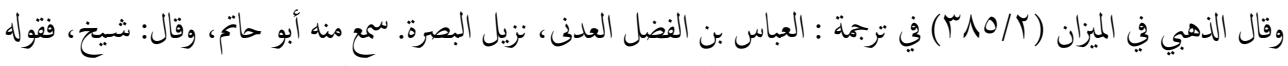

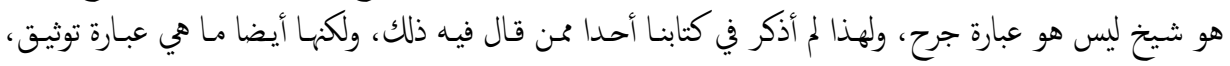
وبالاستقراء يلوح لك لك إنه ليس بحجة.

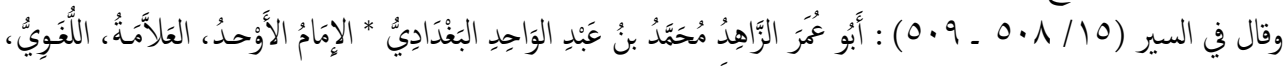

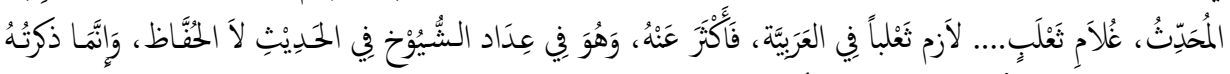

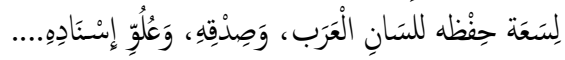

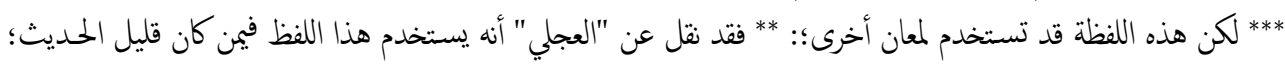

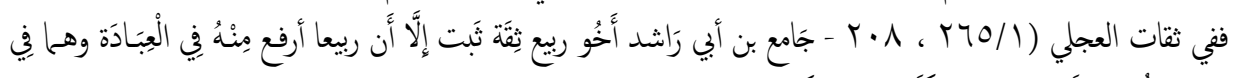

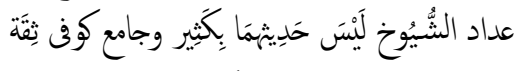

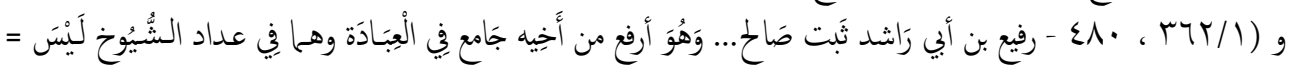




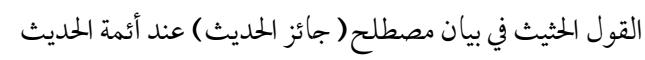

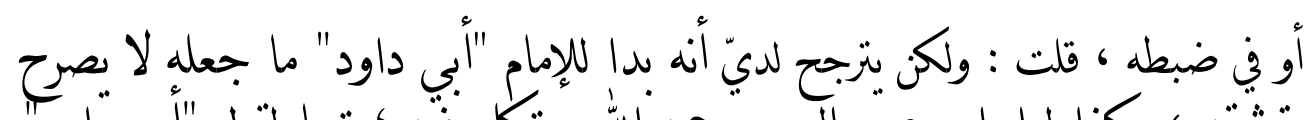

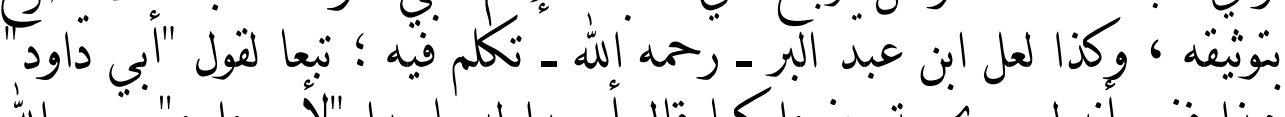

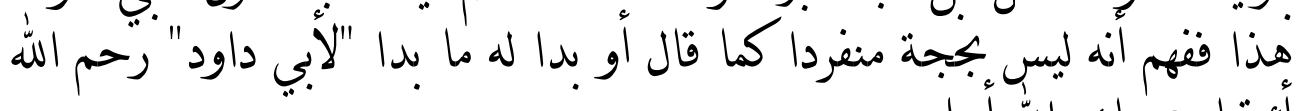

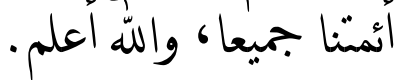

$=$

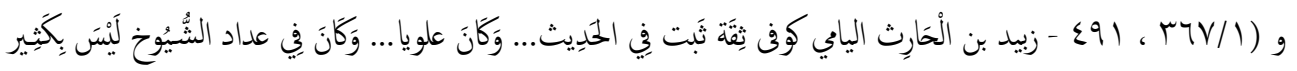
الحَدِيث

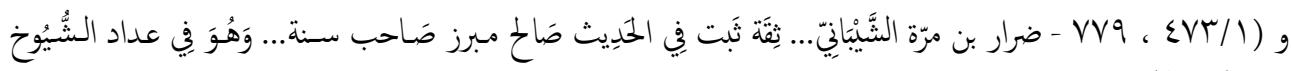

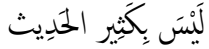

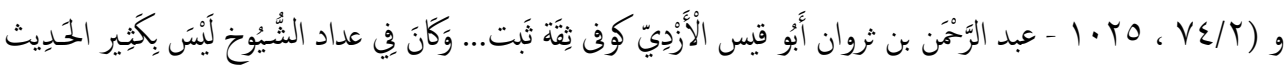

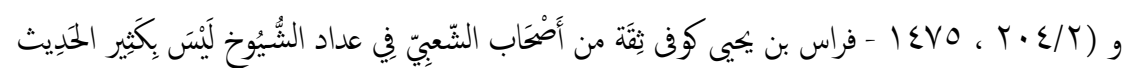

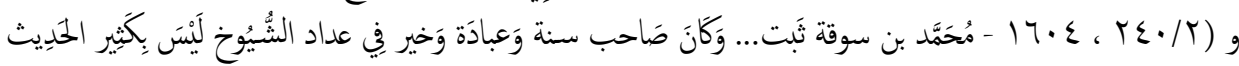

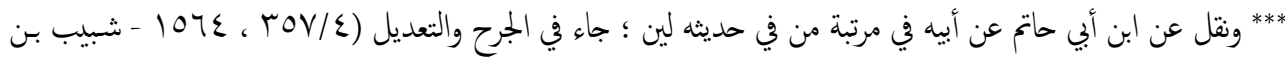

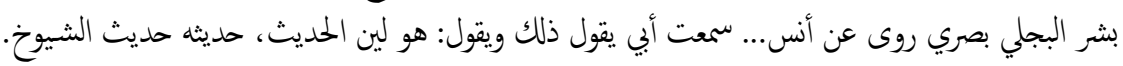

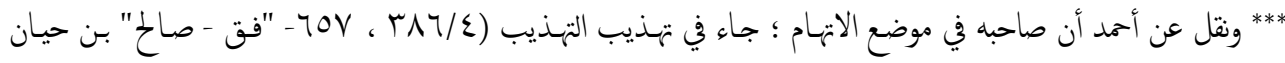

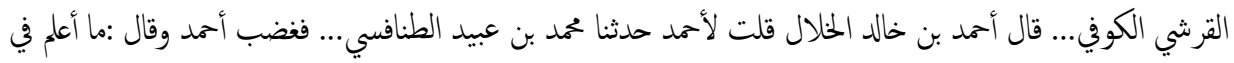

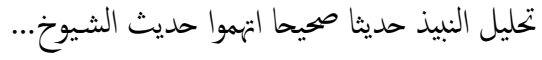

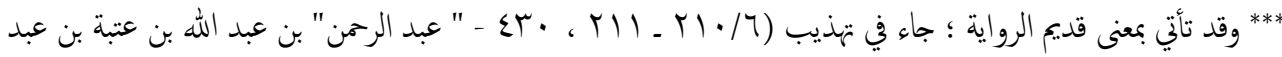

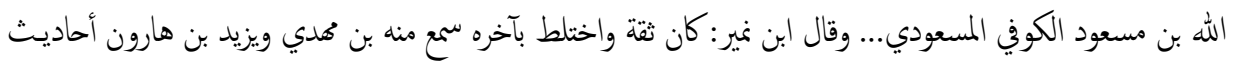
مختلطة ومما روى عنه الشيوخ فهو مستقيم...

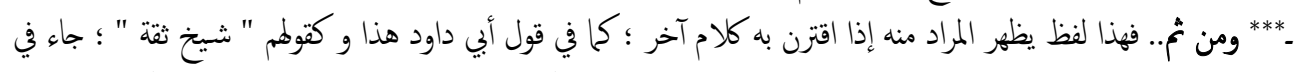

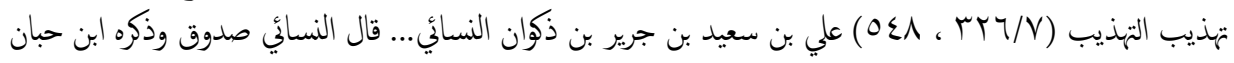

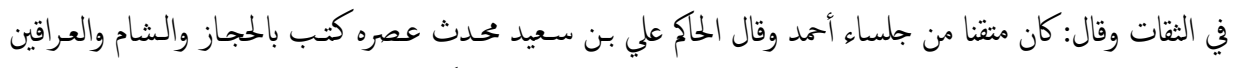

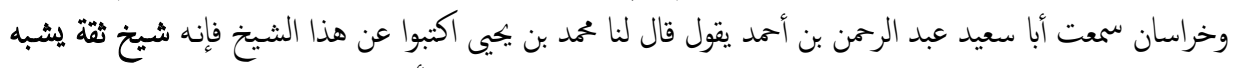

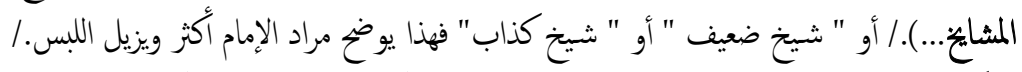

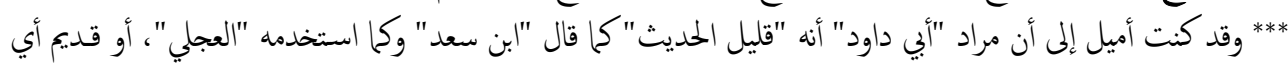

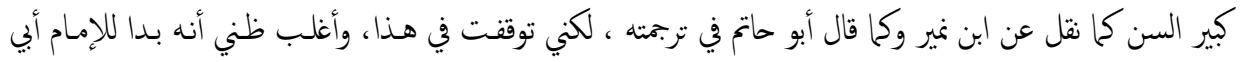

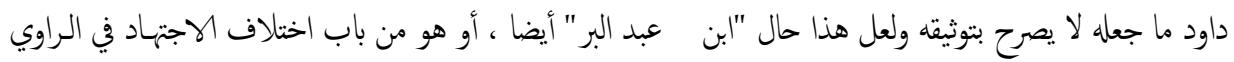

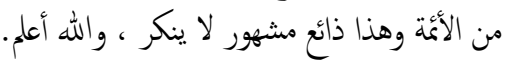
وما جعلني أتوقف قول أبي داود في الترجمين التي سبق الإنشارة إليها : فهو من أقوى الدلائل على أنه ليس توثيقا . 
=

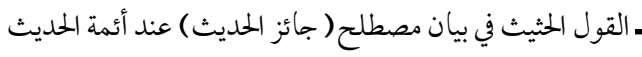

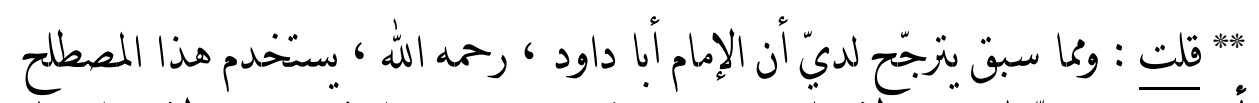

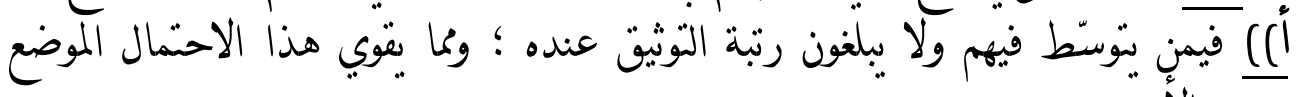
الأخير

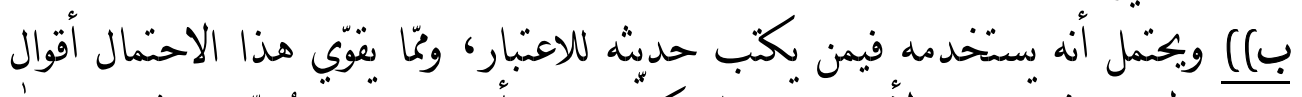

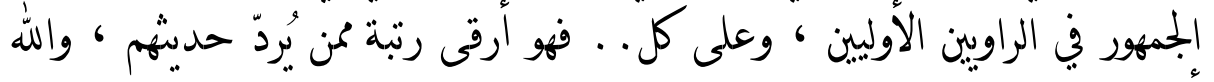
أعلم. 


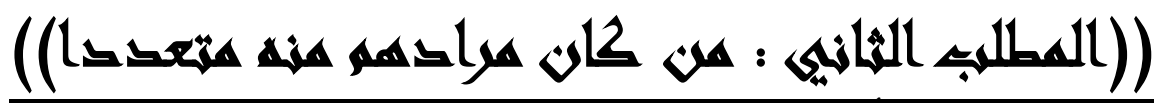

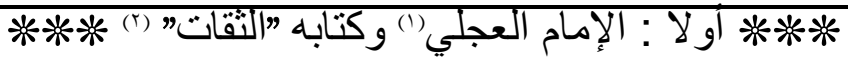

(1)

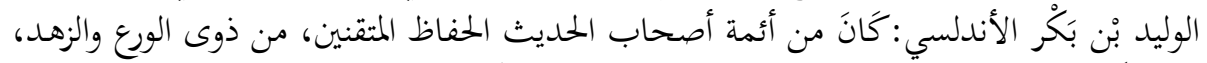

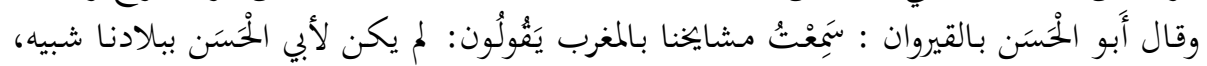

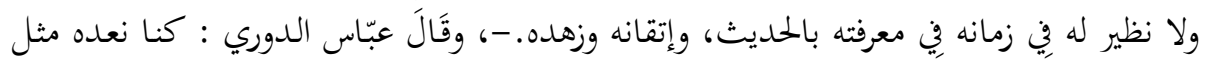

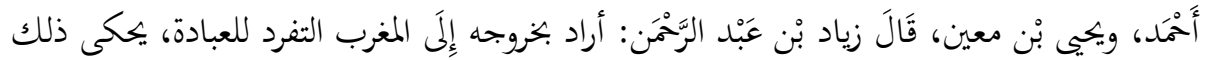

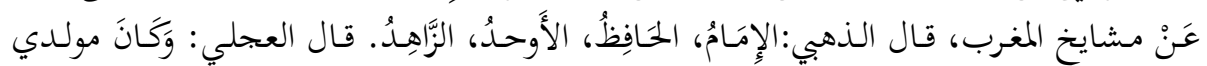

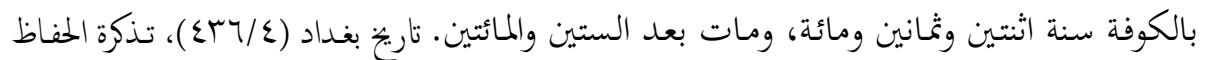

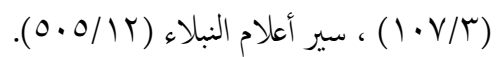

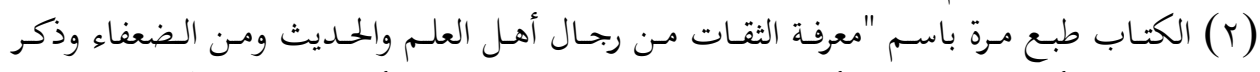

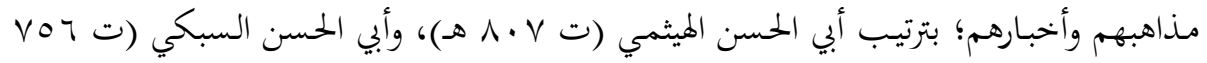

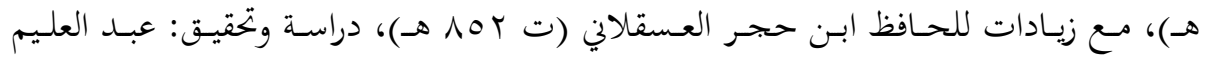

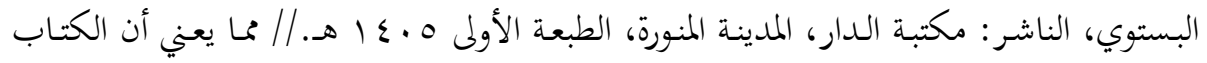

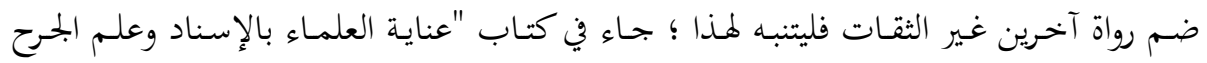

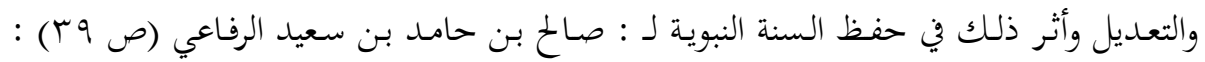

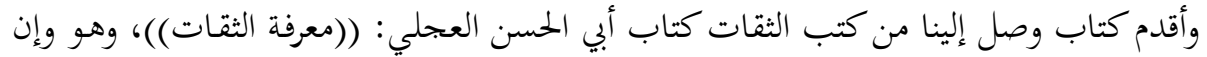

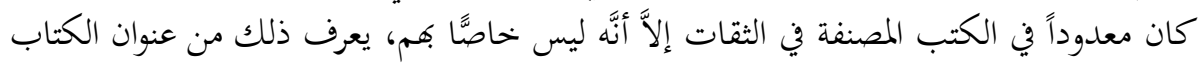

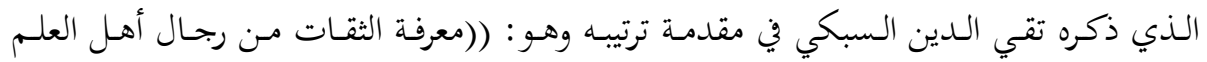

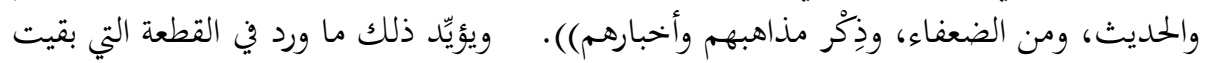

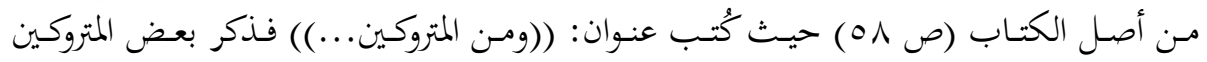
وبعض الضعفاء.

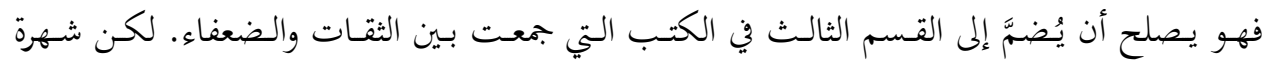

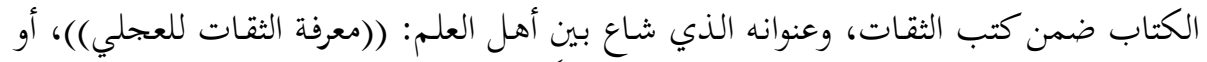

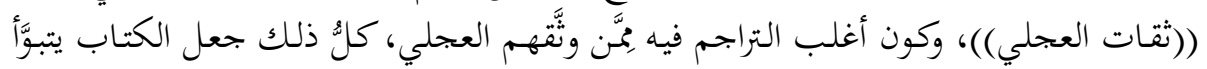
مكان الصدارة بين كتب الثقات الثنات الثبات

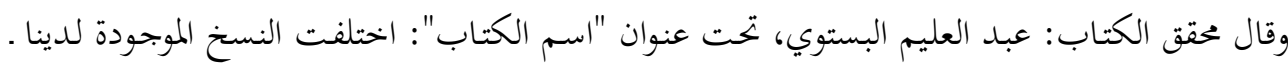

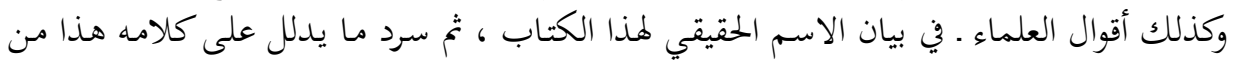

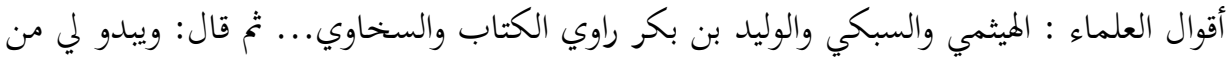

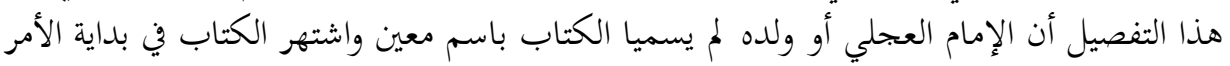

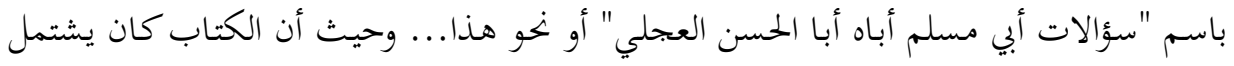

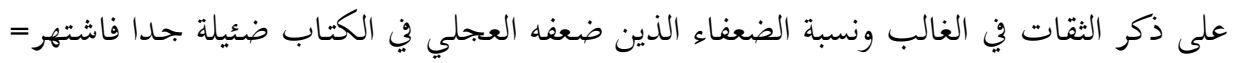


الناظر في منهج الإمام العجلي في استخدام هذا المصطلح يجد له طرقا مختلفة في مراده منه ، وهاك بياها:

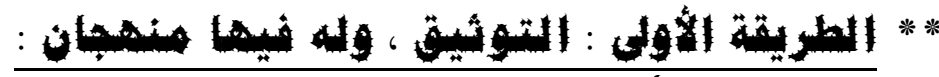

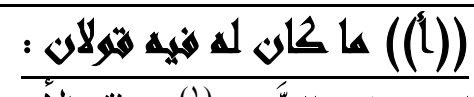

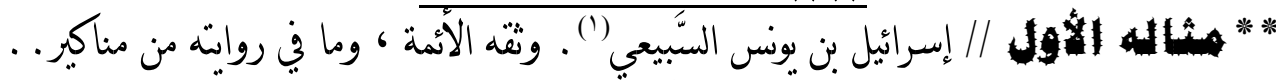

فمن غيره (")

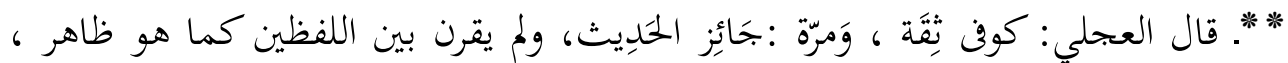

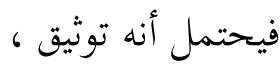

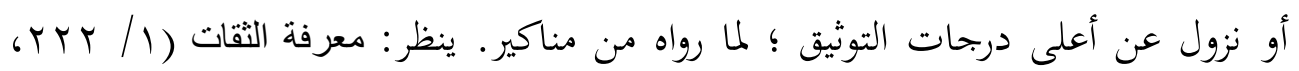

= الكتاب في العصور التالية باسم "الثقات" أو "معرفة الثقات" ولعل أنسب اسم هو مـا جاء في ترتيب السبكي ثم ذكر العنوان المذكور في بداية الفقرة.

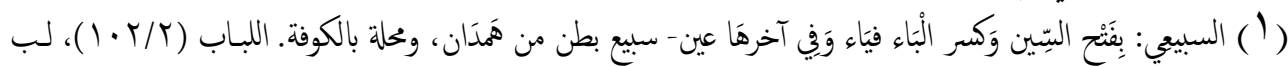

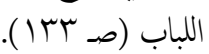

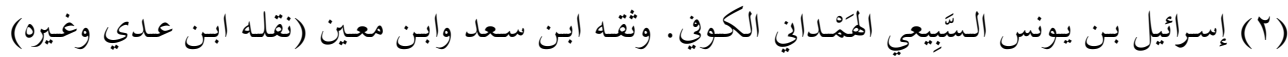

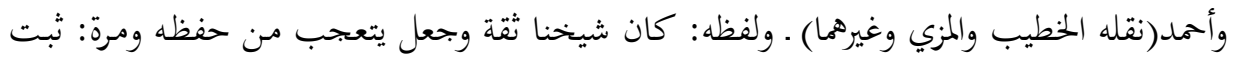

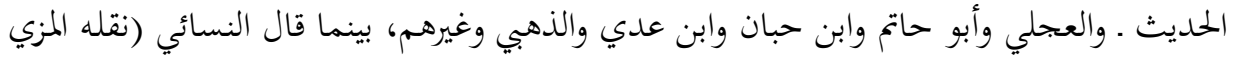

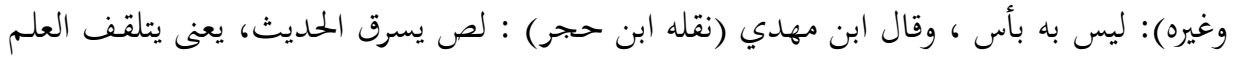

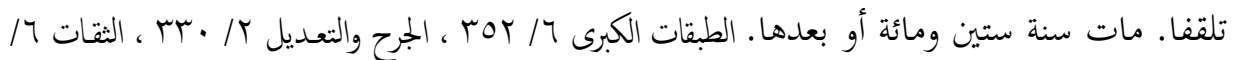

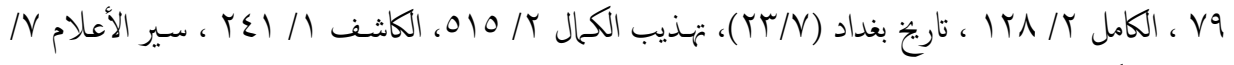

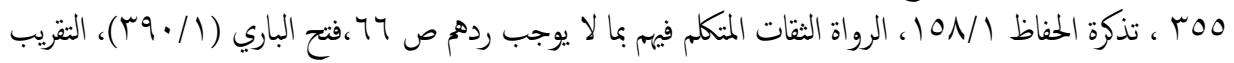

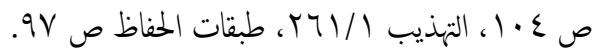

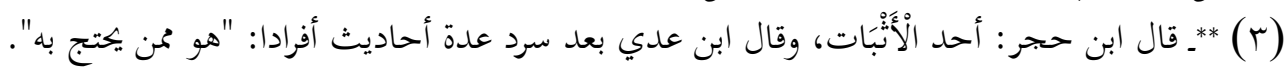

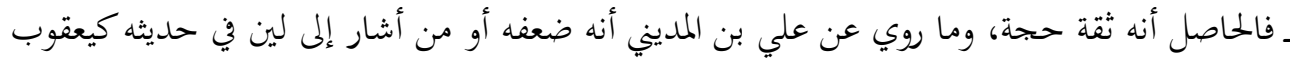

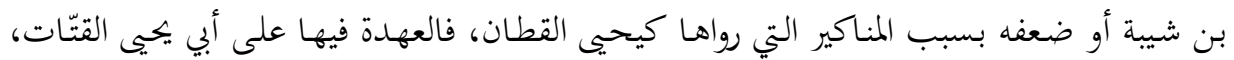

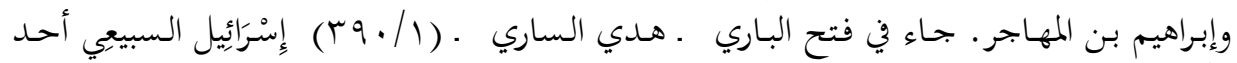

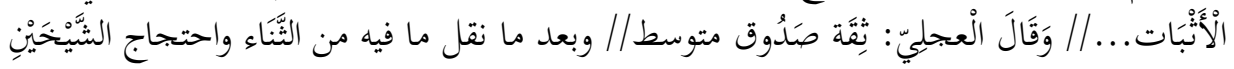

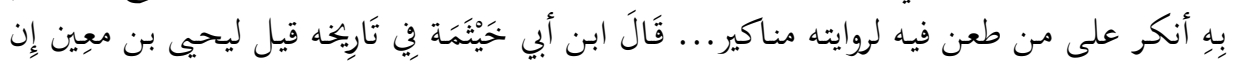

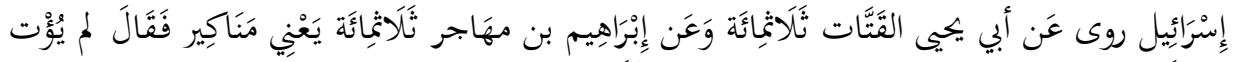

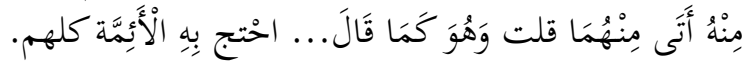

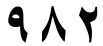




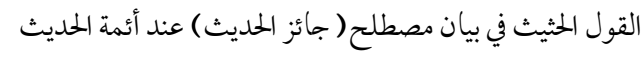

ويؤيد الاحتمال الأخير ما نقله ابن حجر عنه قال: ثِقَّة صَدُوق متوسط ـ ـ هدي الساري ـ

$(r q \cdot / 1)$

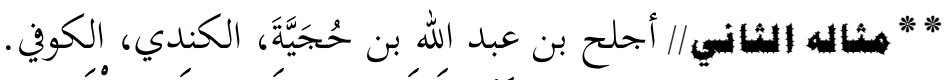

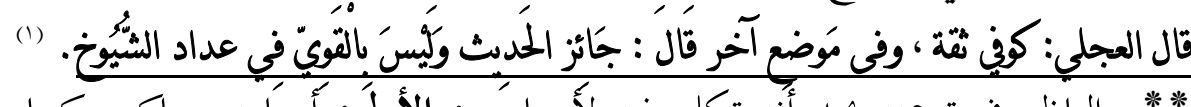

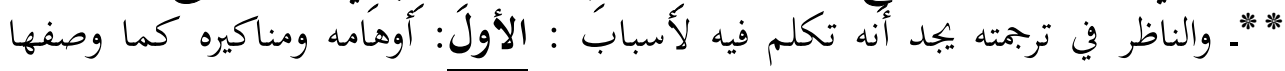

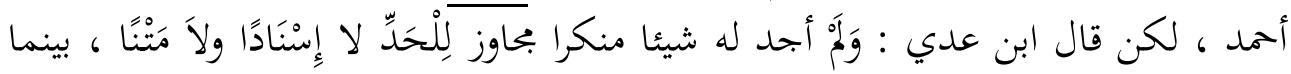
خصّ العقيلي أوهامه بروايته عن الشعبي.

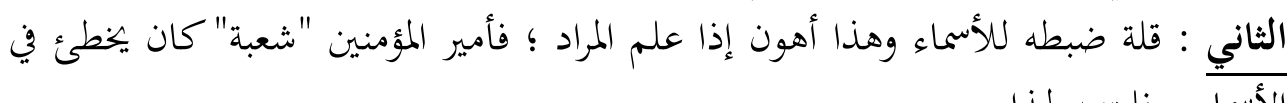
الأسماء ، فليتنبه لهذا. الثالث: اتم بالتشيع اهمه السعدي والنسائي وغيرها، ولعل تشيعه من التشيع الخفيف (r) ؛

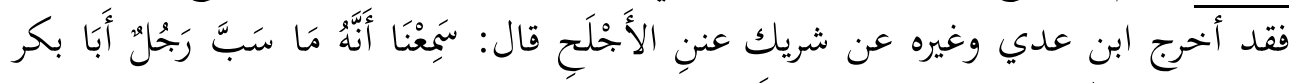

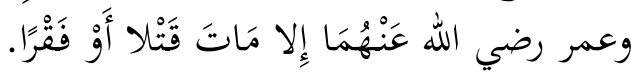

(1) أجلح بن عبد الله بن حُجَيَّة، الكندي الكوفي. قال عباس الدوري والدارمي عن ابن معين: ثقة. ومرة:

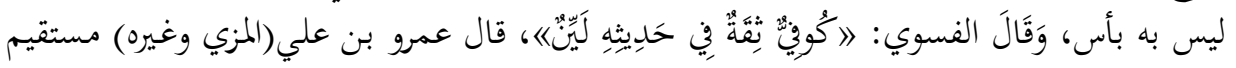

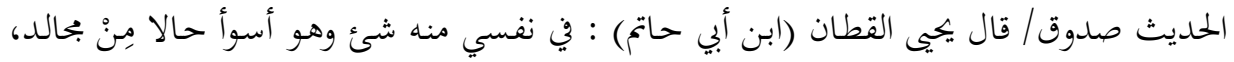

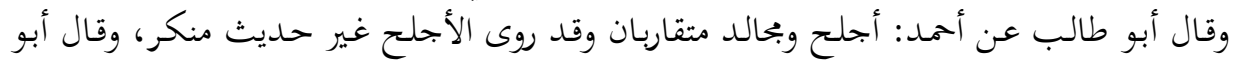

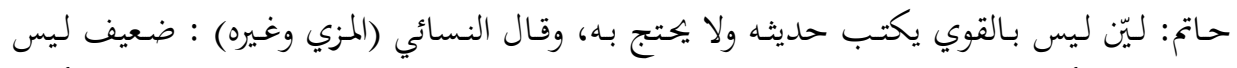

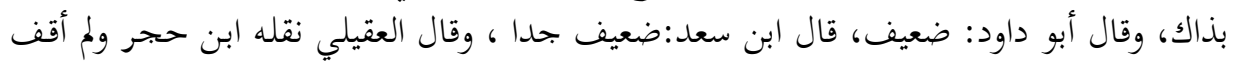

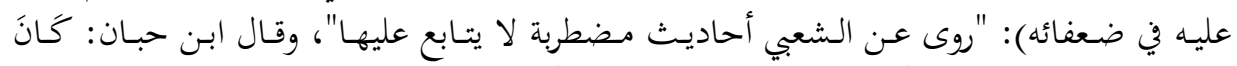

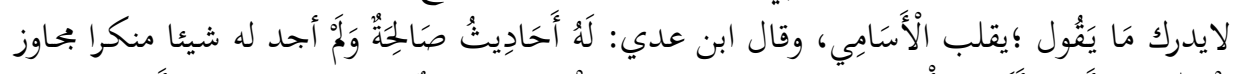

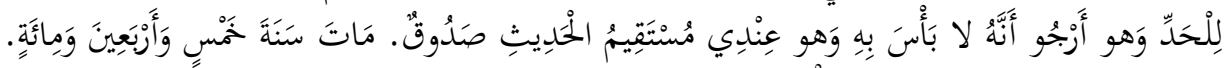

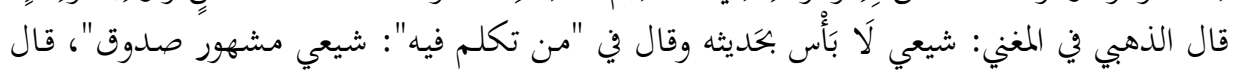

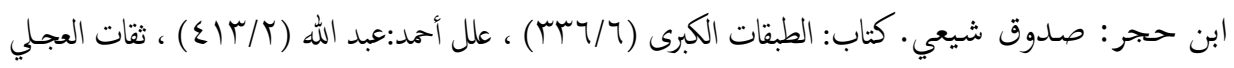

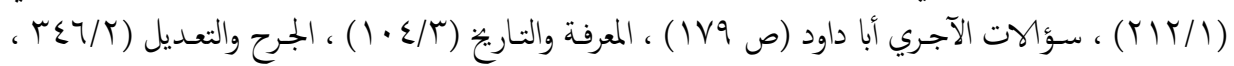

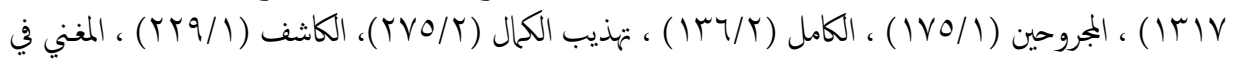

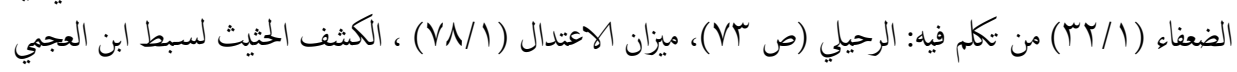
(ص اع) ، التقريب (ص (97)، التهذيب (1) (1) (1).

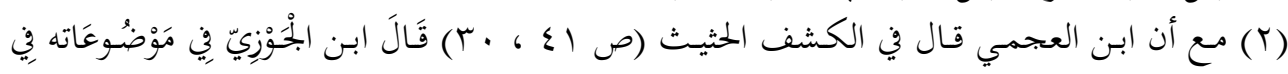

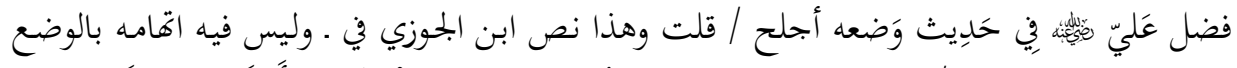

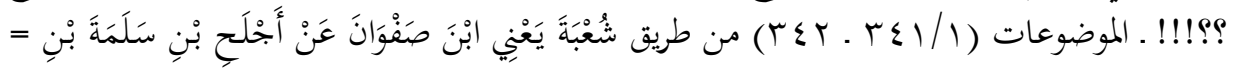




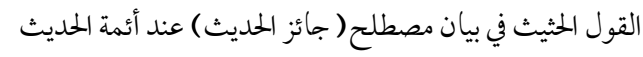

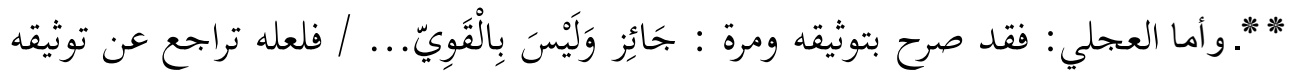

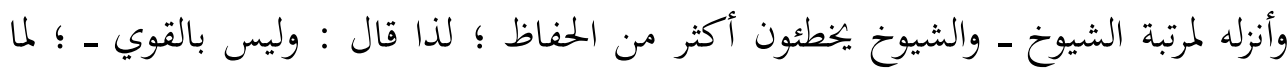
ذكر فيه من أخطاء وتشيُّع ، والله أعلم.

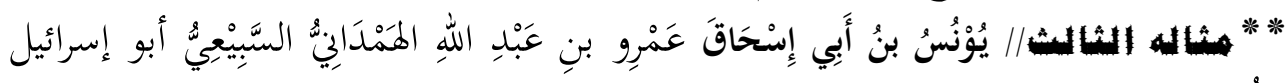
الكُكوفْيُ..

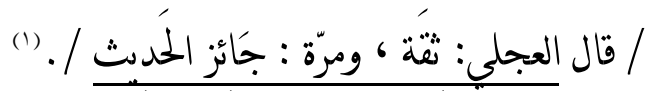

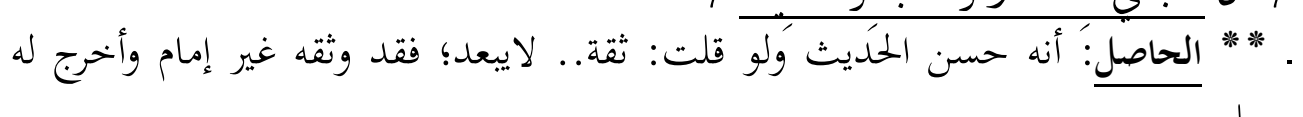
• مسلم

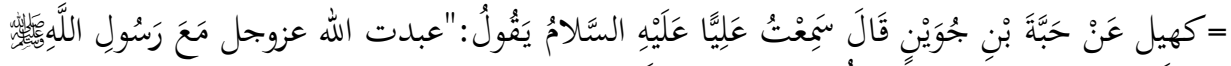

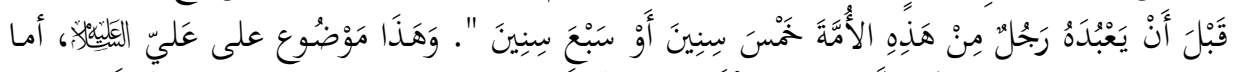

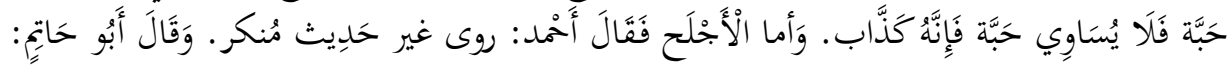

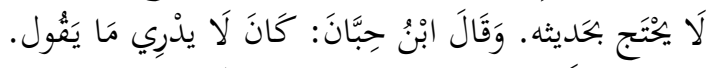

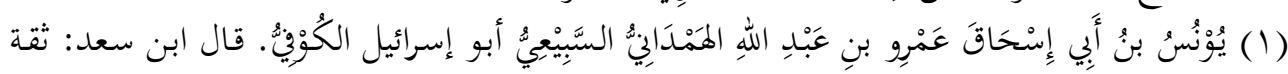

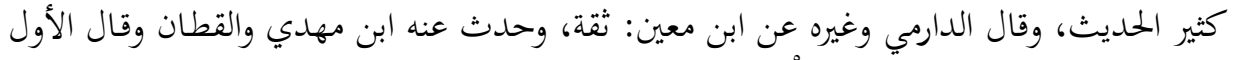

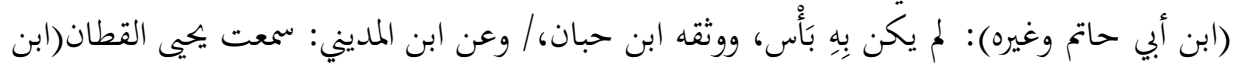

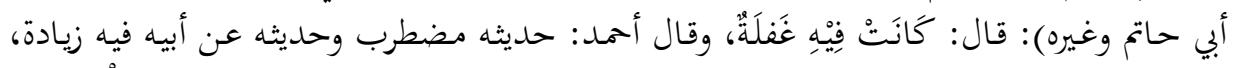

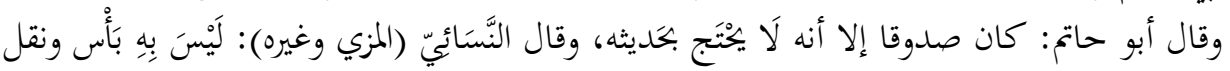

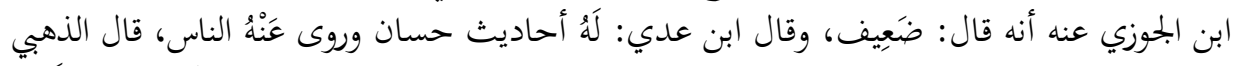

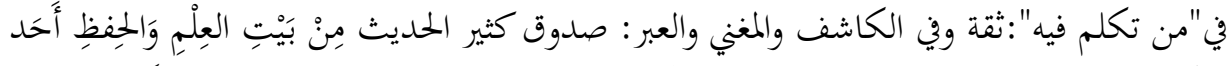

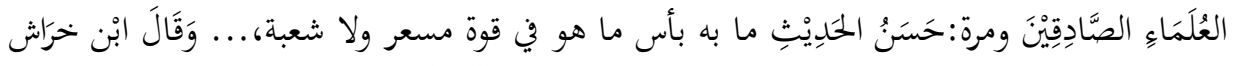

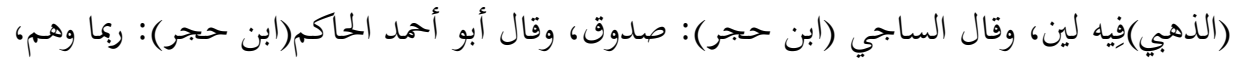

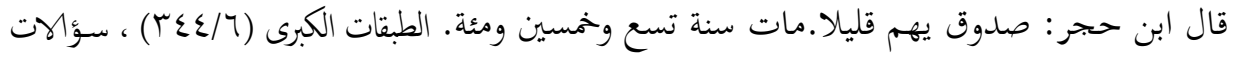

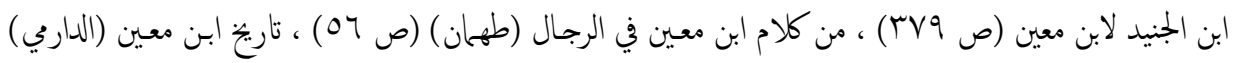

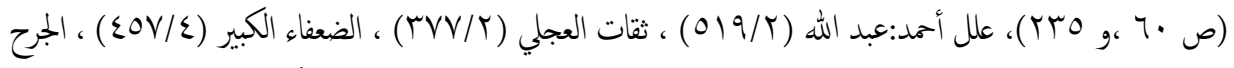

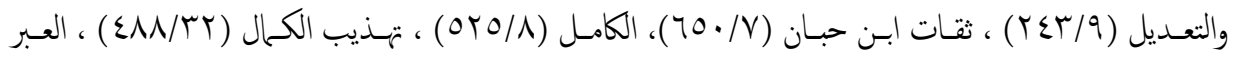

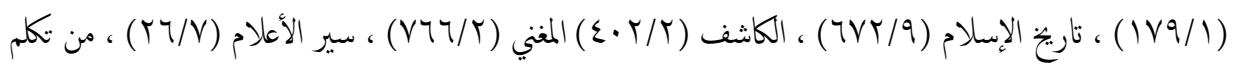

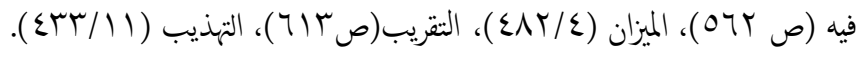


وتكلم في حديثه عن أبيه ؛ لزيادته فيه كما بيّن أحمد ، وهو كثير الحديث كما أشار ابن أنداء

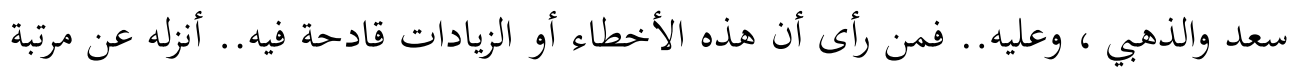

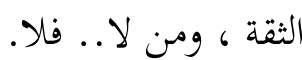

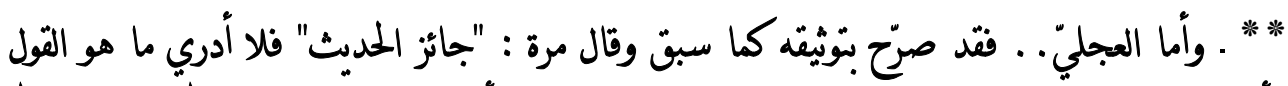

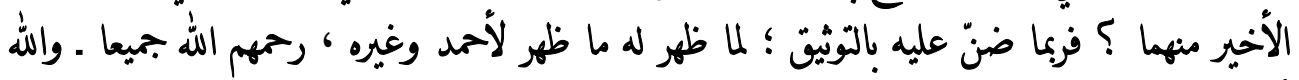
يُوسُف بن يُونُس بن أبي إِسْحَاق : كوفن تِقَّة، وَقَالَ مرّة : جَائز

||

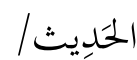

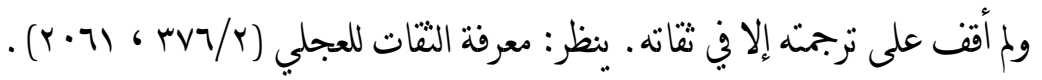
楼楼楼米

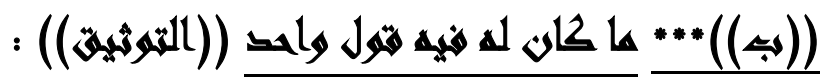

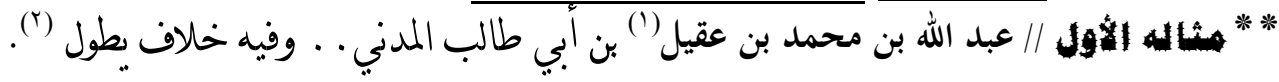

(') بفتح العـين المهملة وكسر القـاف وسـكون اليـاء المنقوطة بـاثنتين مـن تحتها. الأنساب للسمعاني . (rr $(r / q)$

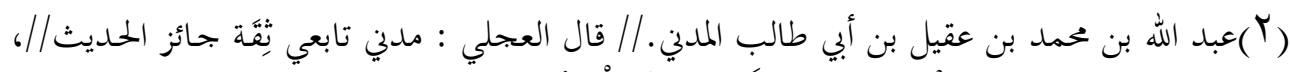

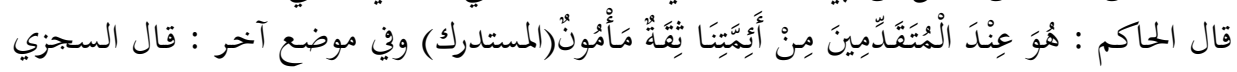

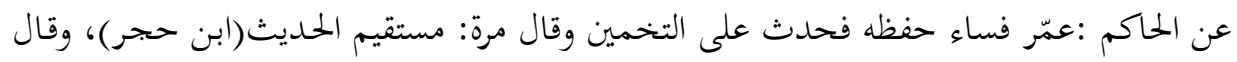

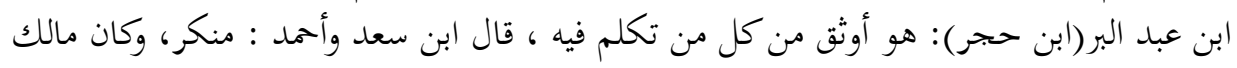

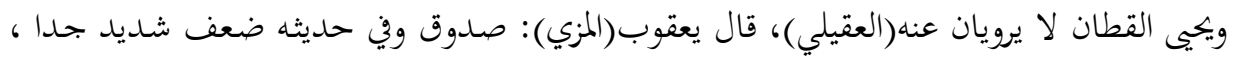

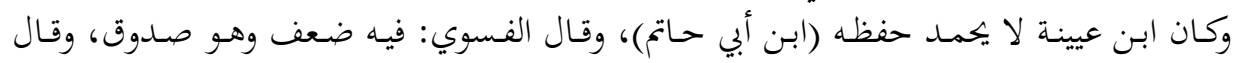

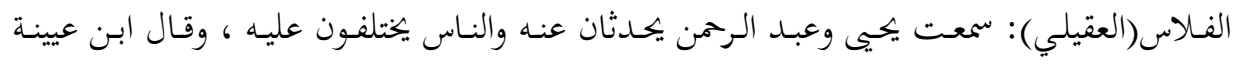

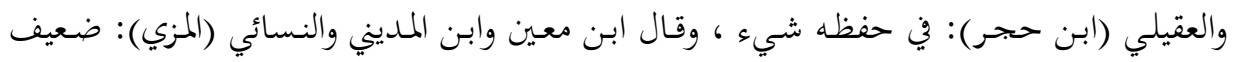

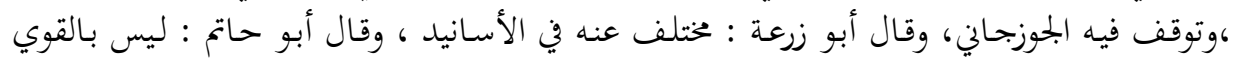

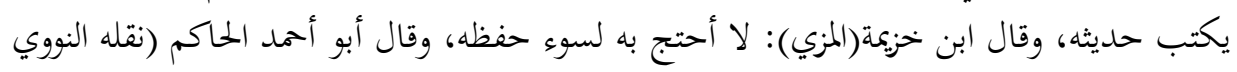

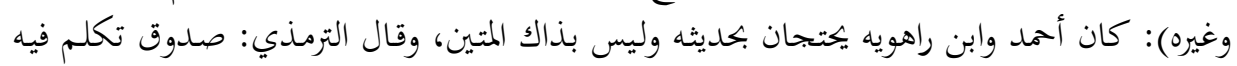

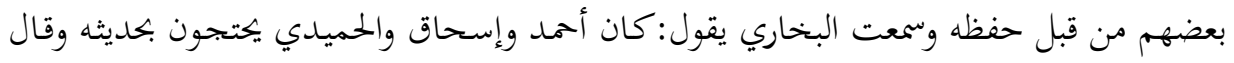

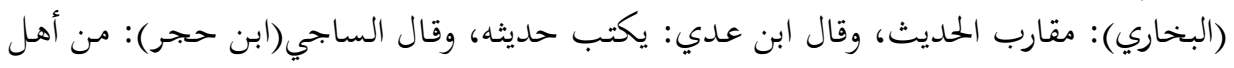

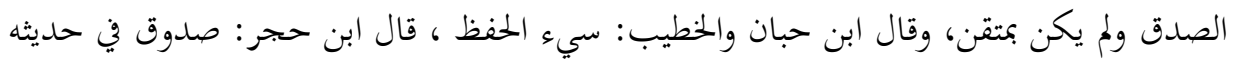

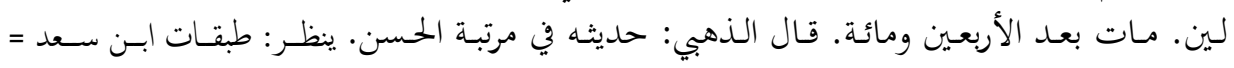




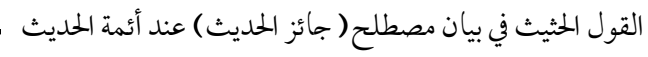

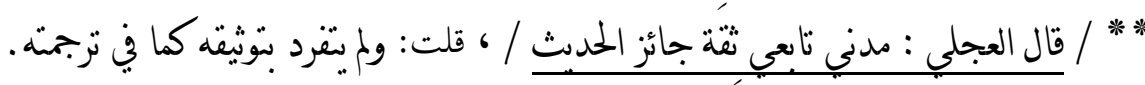
|/ عطاء بَّ السائب بن مالك الثقفي الكوفي. حكموا بتوثيقه وصلاحه

وباختلاطه بآخره (')

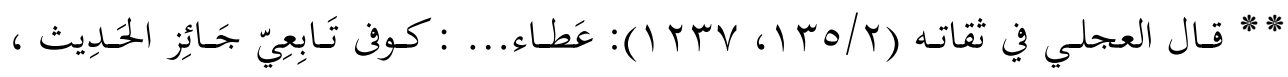

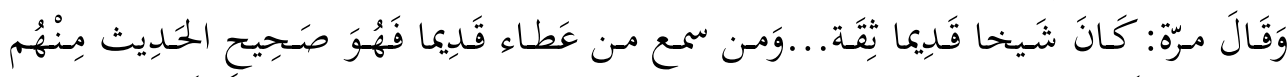

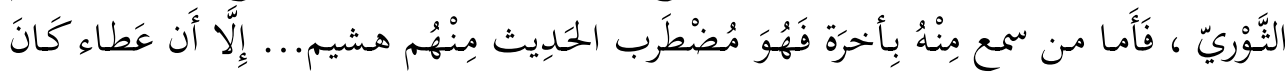

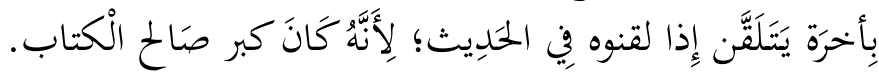

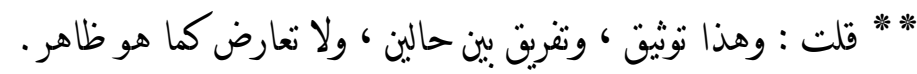

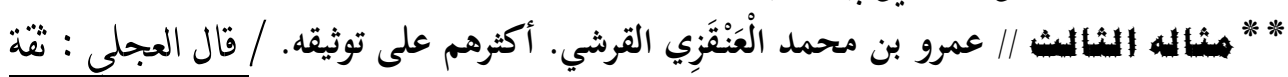

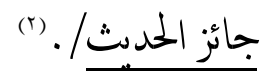

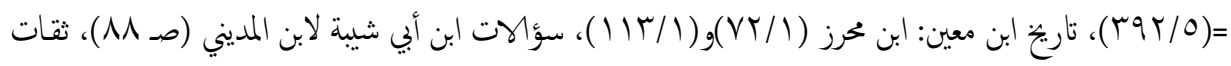

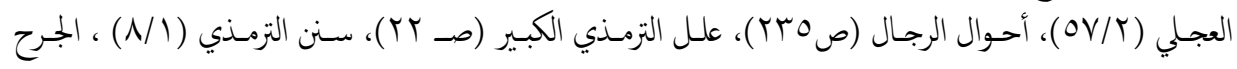

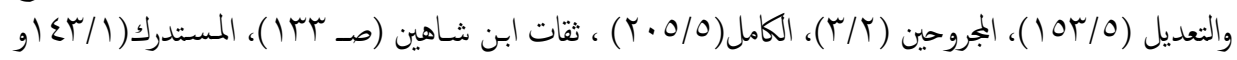

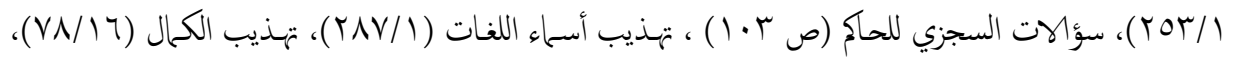

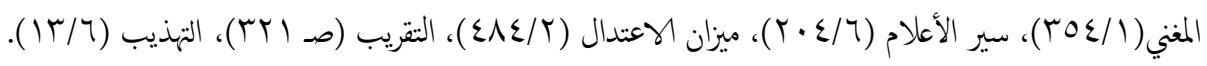

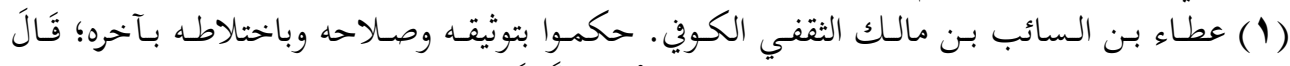

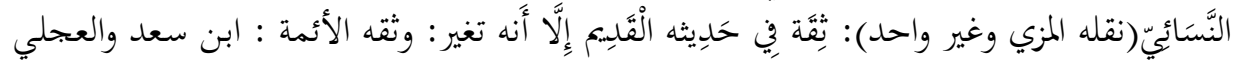

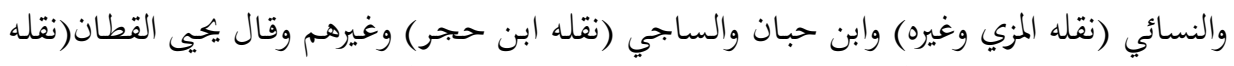

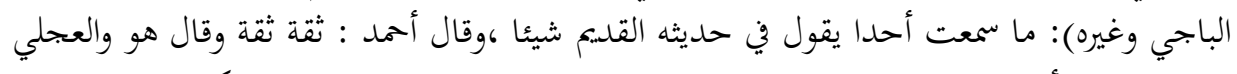

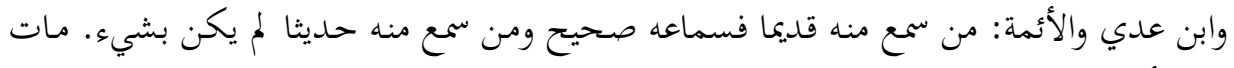

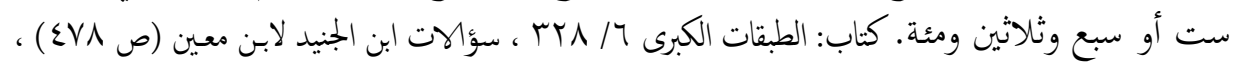

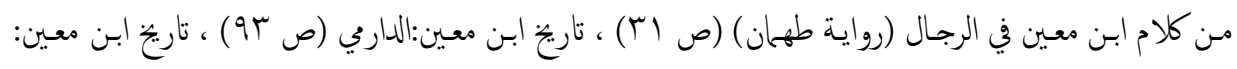

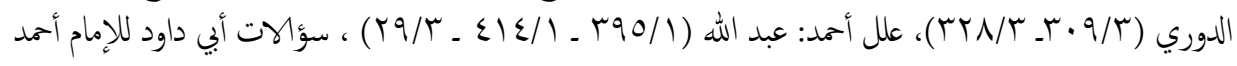

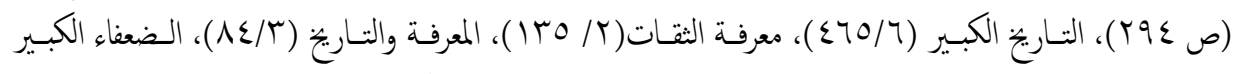

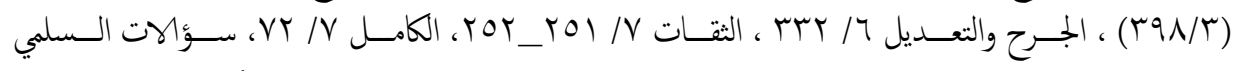

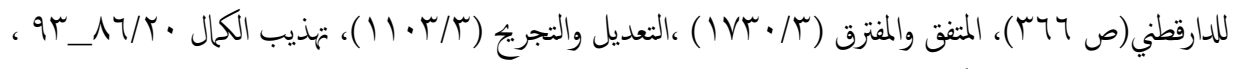

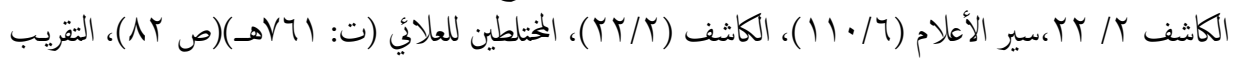

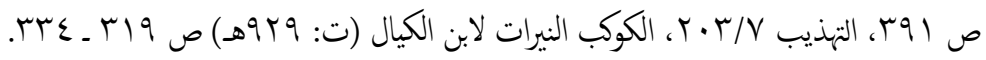

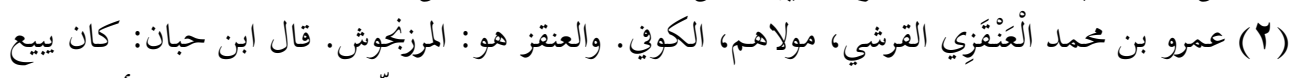

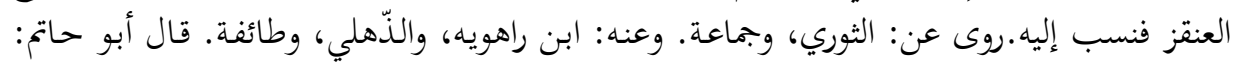

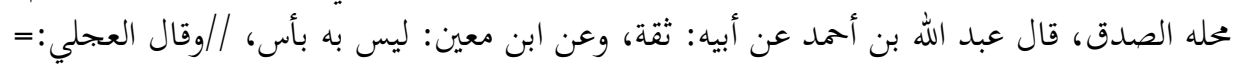




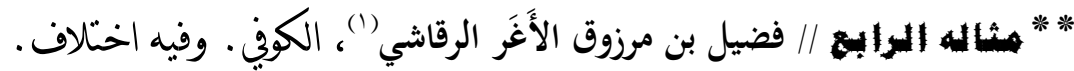

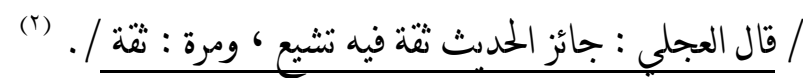

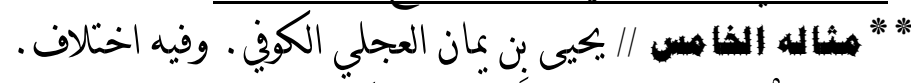

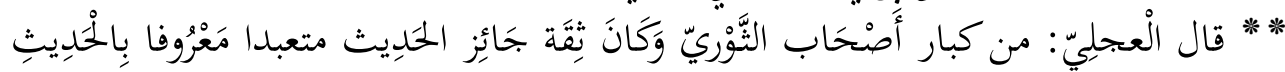

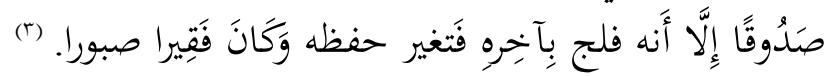

= ثقدة جائز الحديث//، وقال النسائي(المزي وغيره) وابن حجر والذهبي: ثقـة وقال الأخير مـرة:

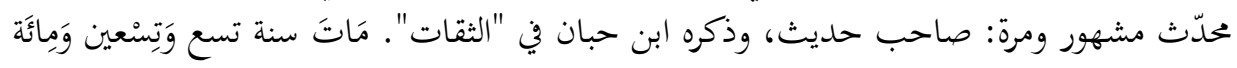

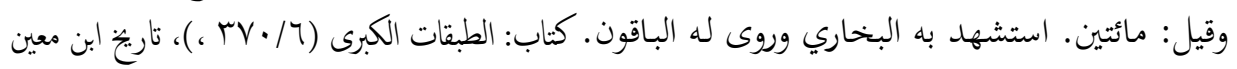

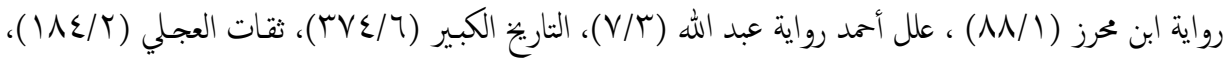

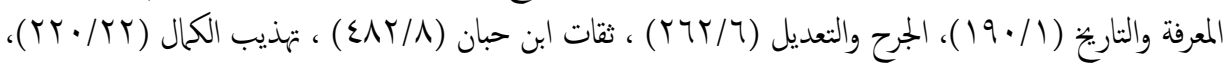

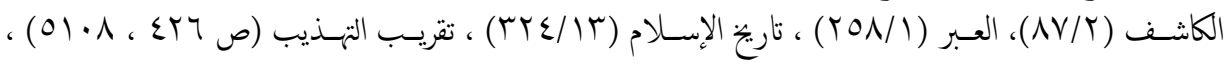

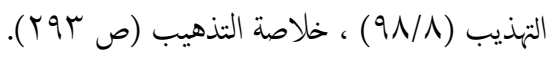

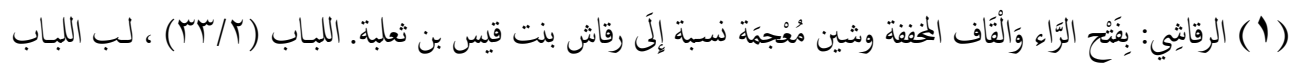
(1) (1IV (1).

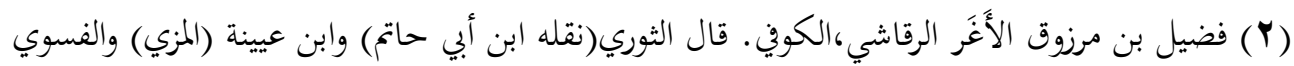

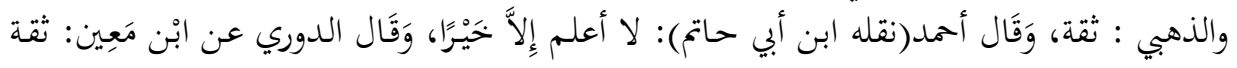

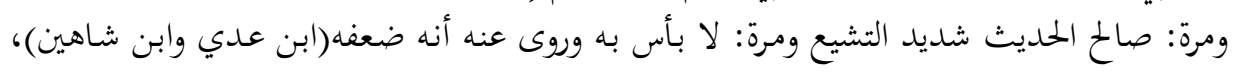

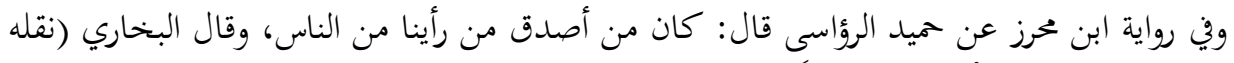

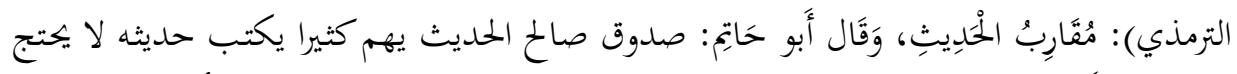

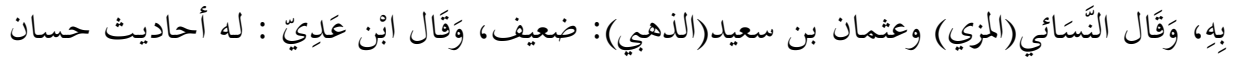

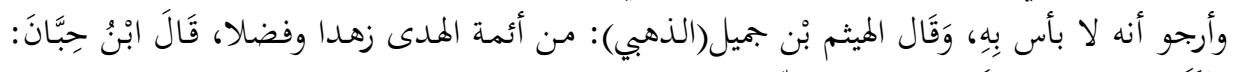

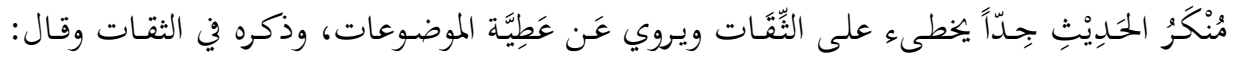

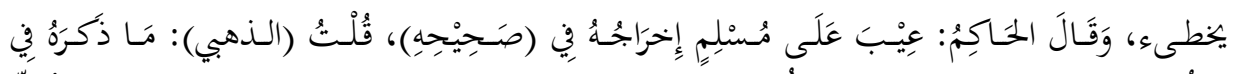

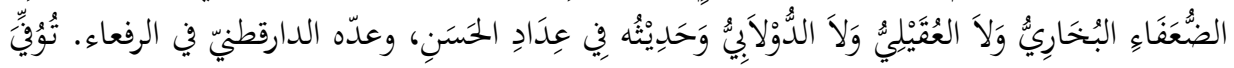

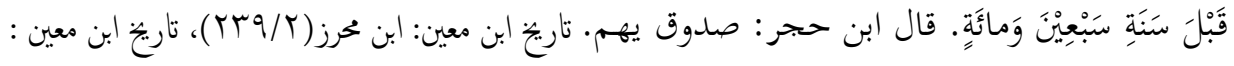

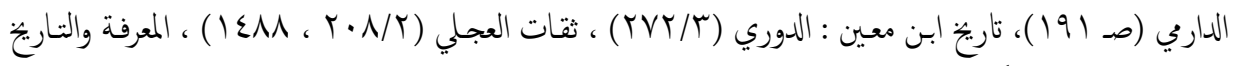

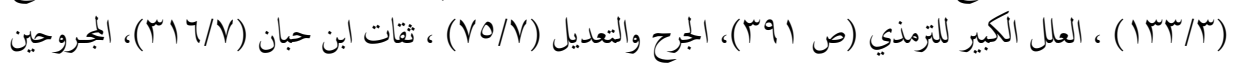

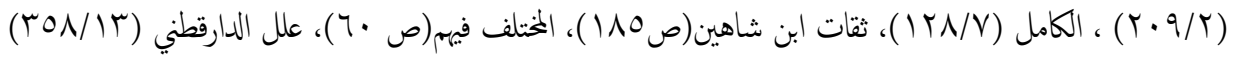

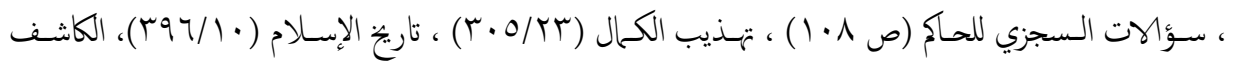

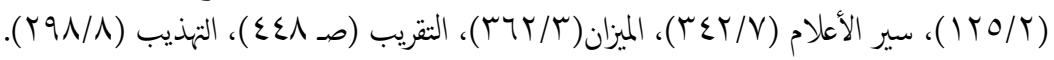

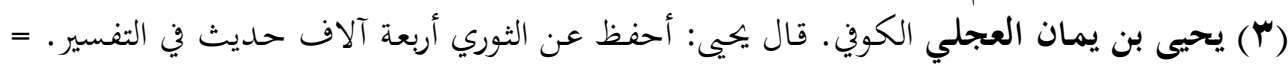




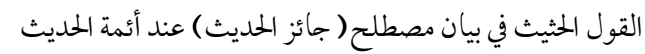

ـ الحاصل: أنّ عددا من الأئمة وتّقّه وحتى من لم يوثنقه أقرّ بسعة حفظه ـ لكنه كثير النسيان

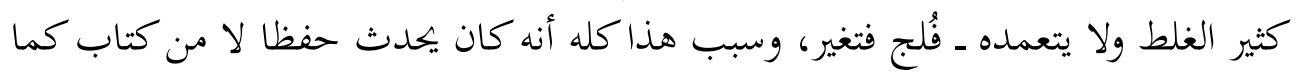
بيّن ابن عمّار .

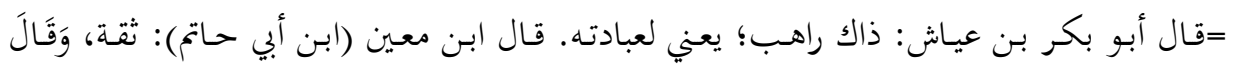

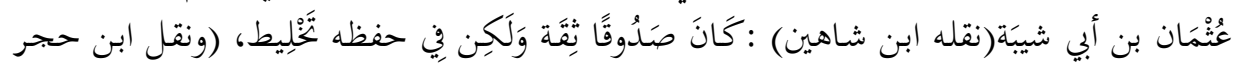

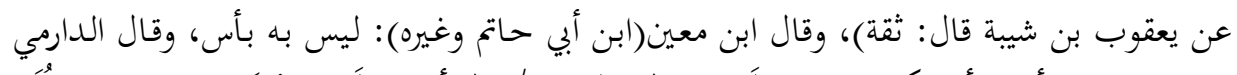

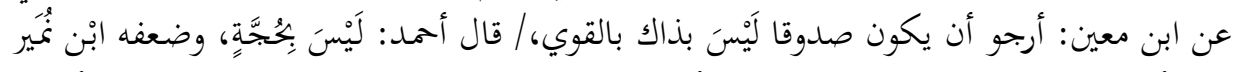

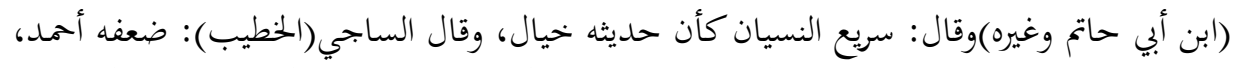

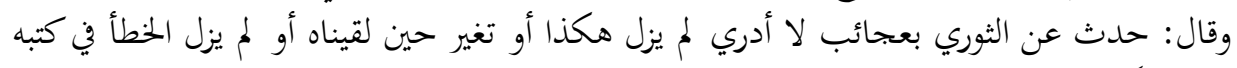

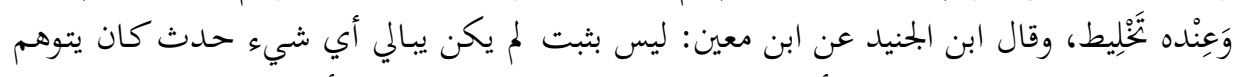

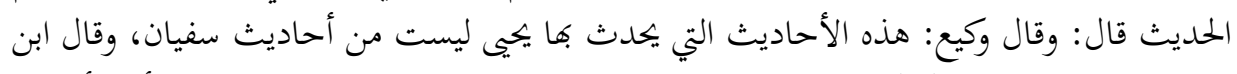

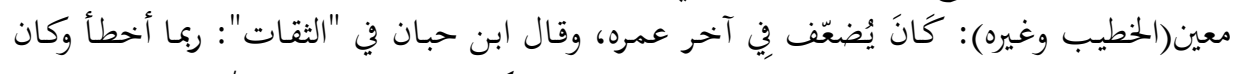

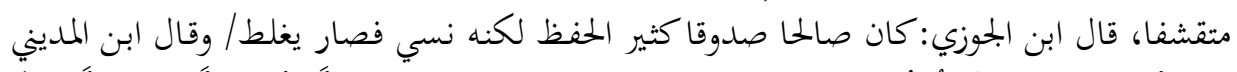

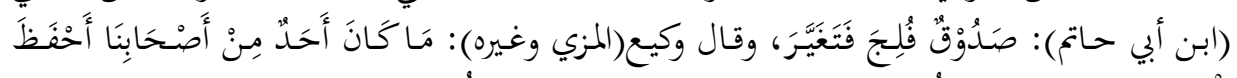

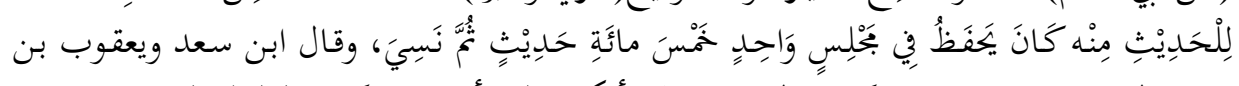

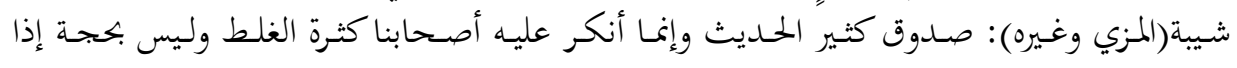

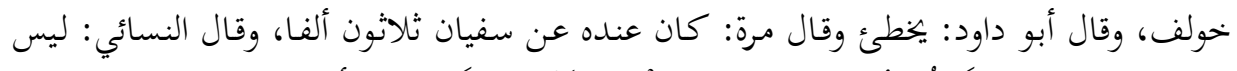

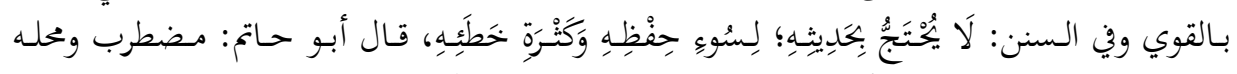

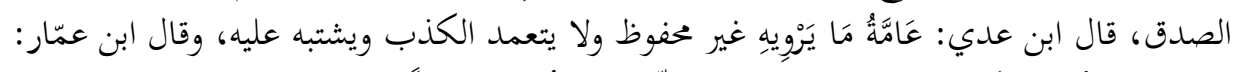

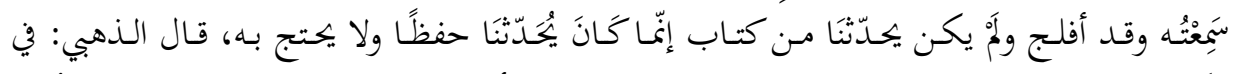

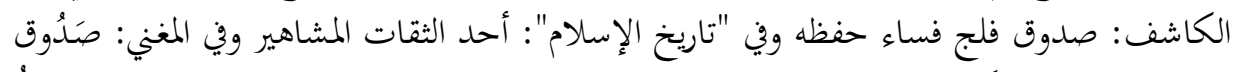

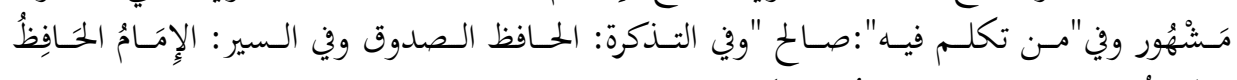

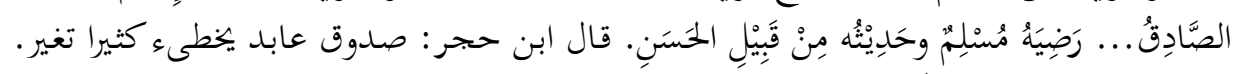

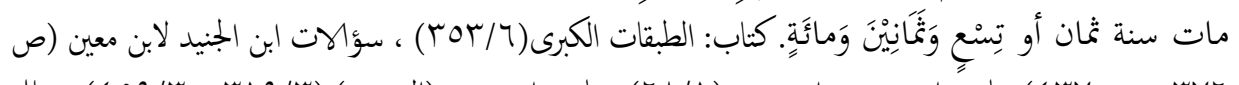

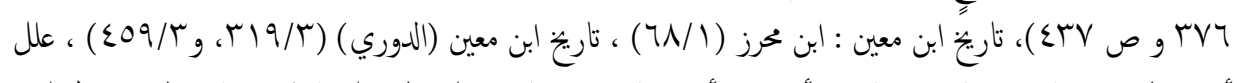

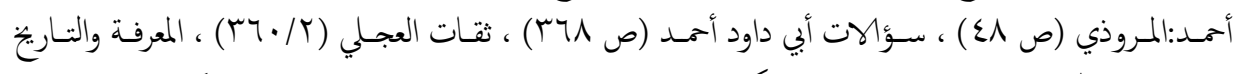

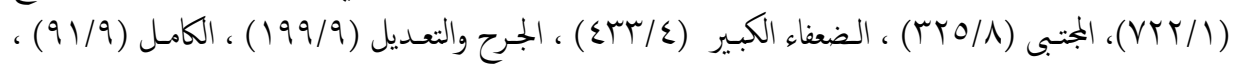

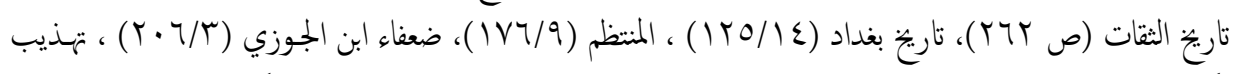

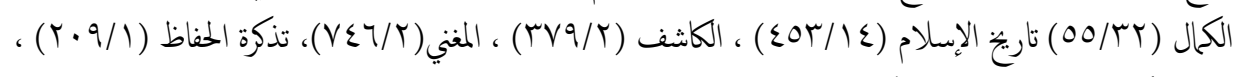

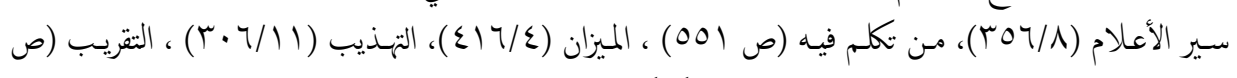

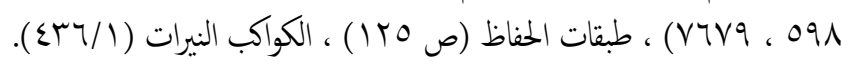




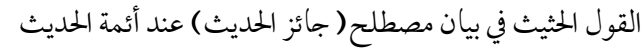

- وأما من رضيه.. كمسلم كما أشار الذهبي.. فطريقة صاحبي الصحيح مشهورة بتجنب أوهام الراوي. ـ وأما الاحتجاج بها.. فلا ؛ خاصة بعدما فُلج، والعجلي قرن التوثيق بجواز حديثه ثم بيّن تغيره فيما بعد.

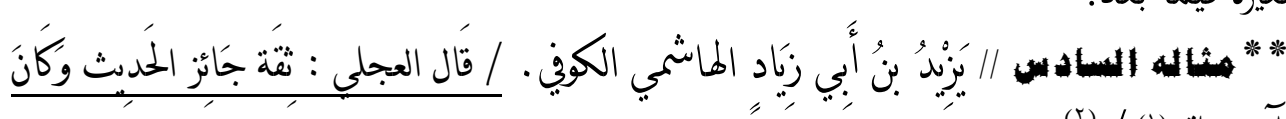
(1) آخره بلقن (1) "قُ قَلت : هو إلى الضعف ما هو؛ بسبب اختلاطه وإتيانه بالمناكير بعد ـ وإن كان في بداية

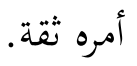

(1) جاء في البناية شرح الهداية لـ: بدر الدين العينى (المتوفى: 100/هـ) ، الناشر: دار الكتب العلمية - بيروت، لبنـان

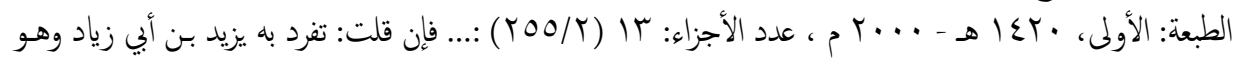

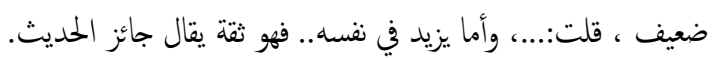

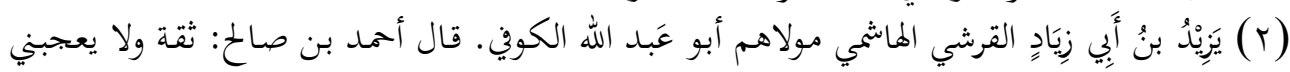

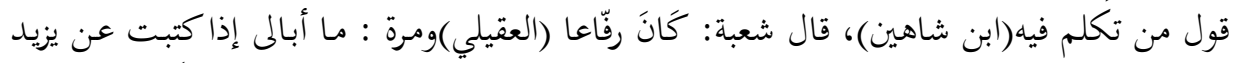

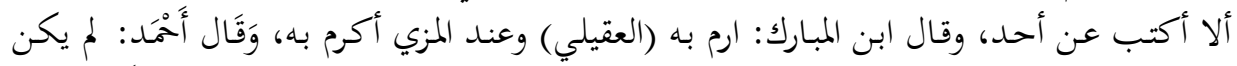

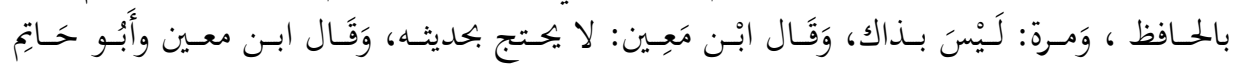

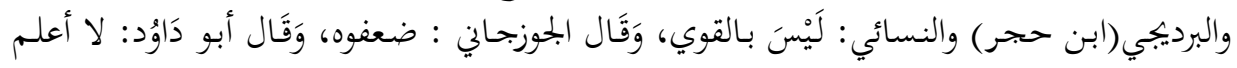

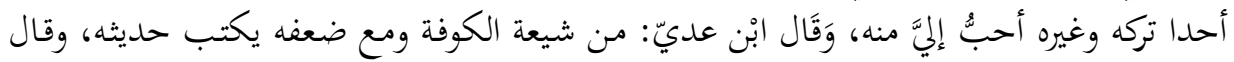

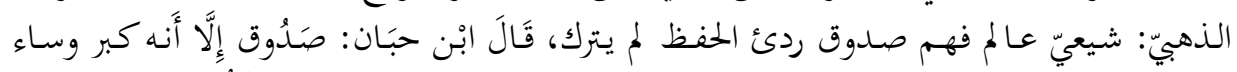

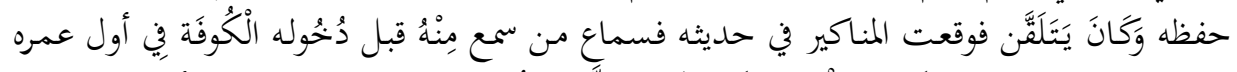

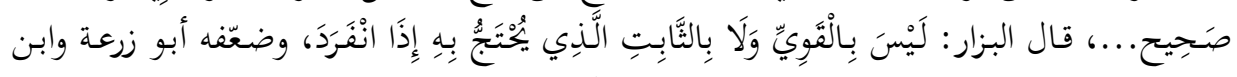

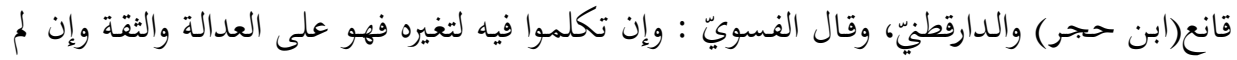

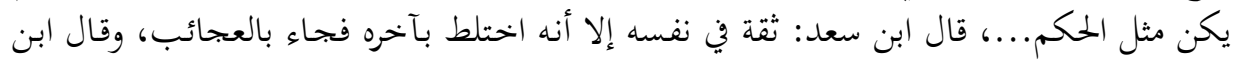

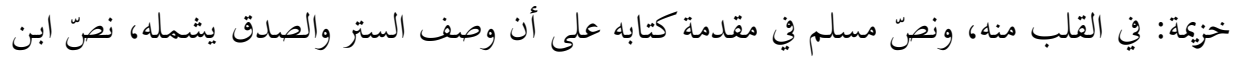

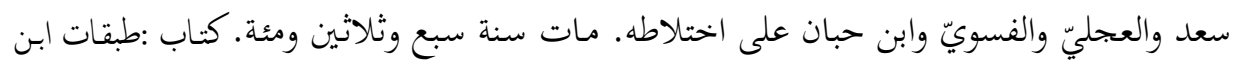

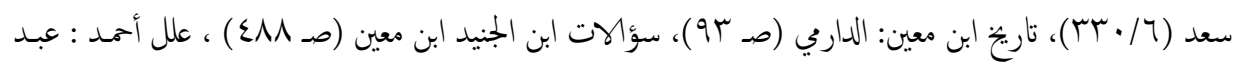

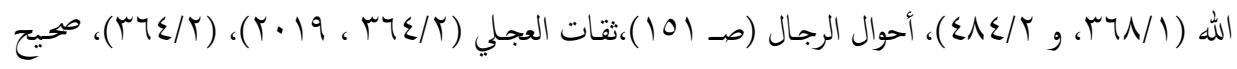

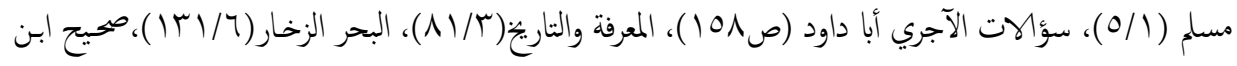

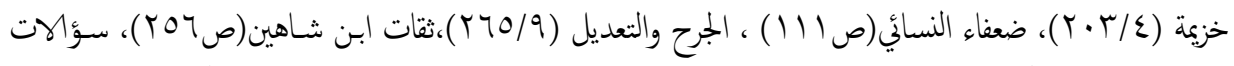

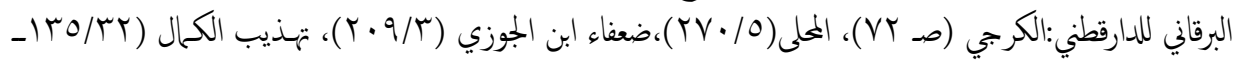

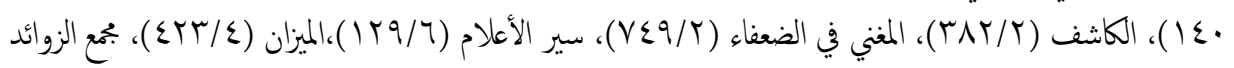

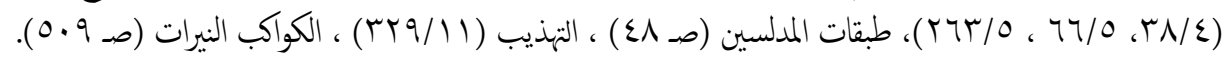




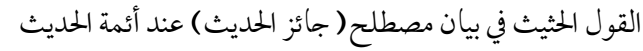

ـ ومن ثتم.. فكالام العجليّ، رحمه الله ، لا يتناقض مع كلام الأئمة ؛ فهو من وتّقهه قبل اختالاطه بآخره.

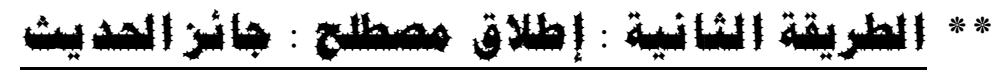

\section{وله فيها منهجان :

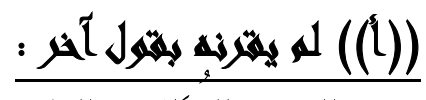

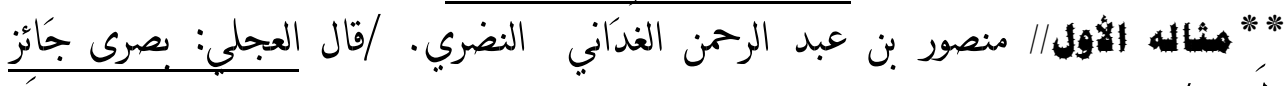
(1). الحدبث:

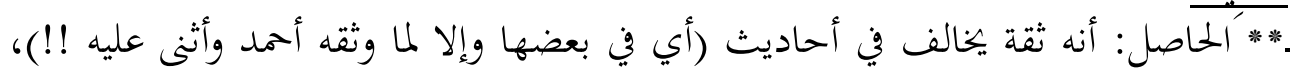

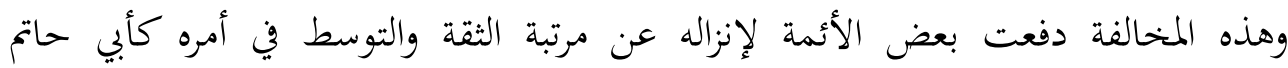

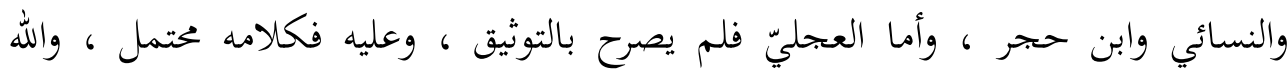

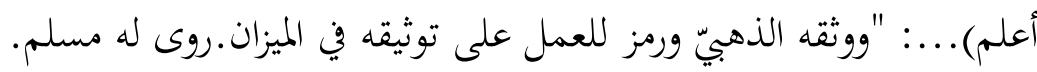

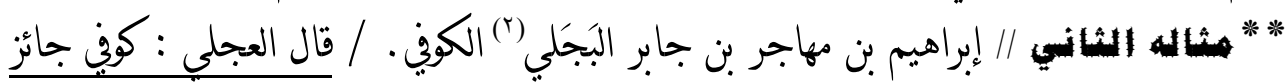
(5)/ الحدبث

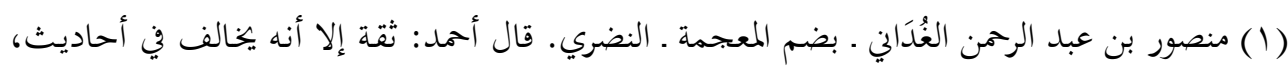

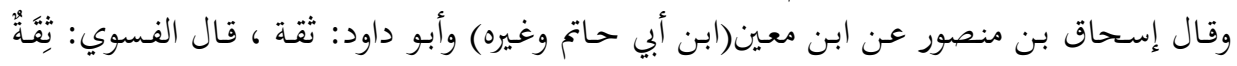

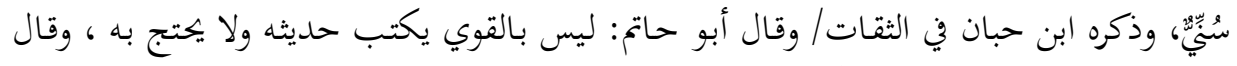

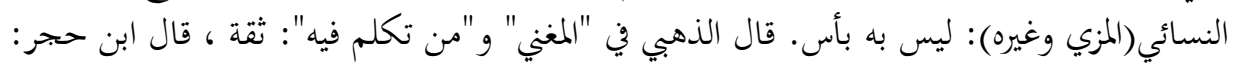

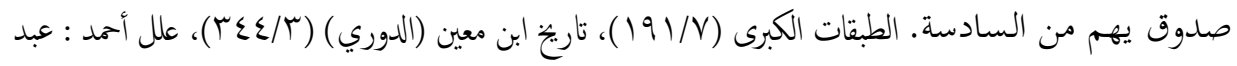

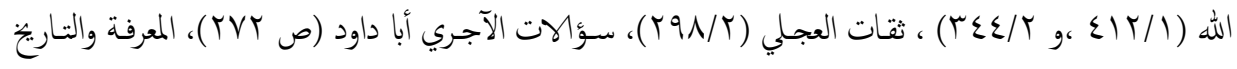

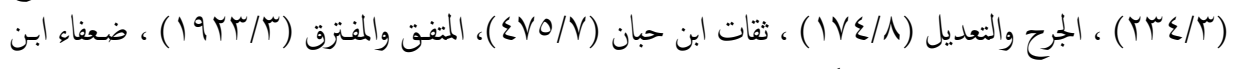

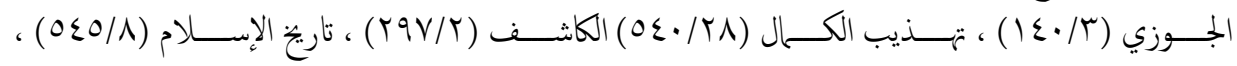

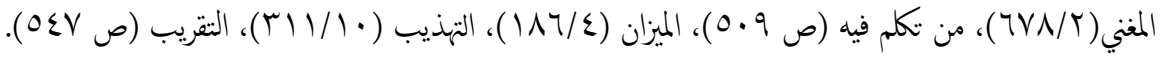

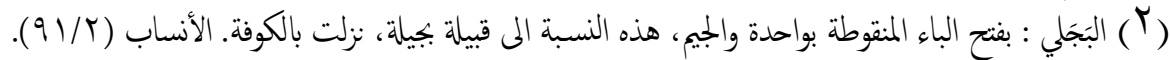

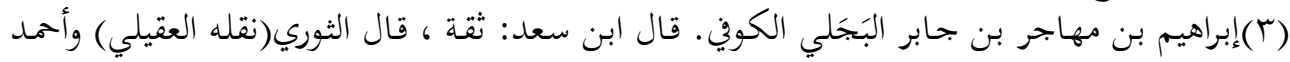

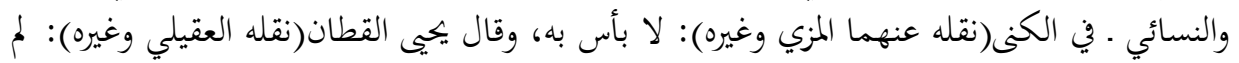

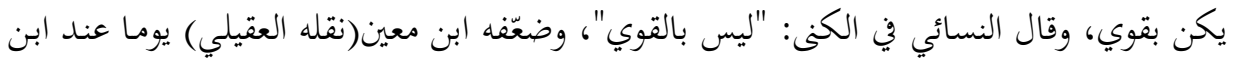

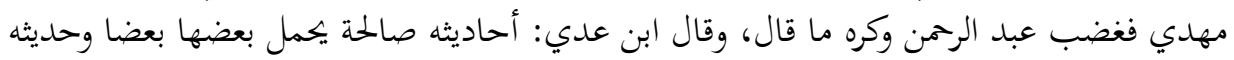

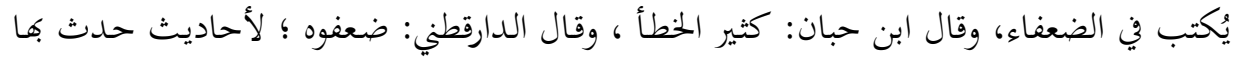

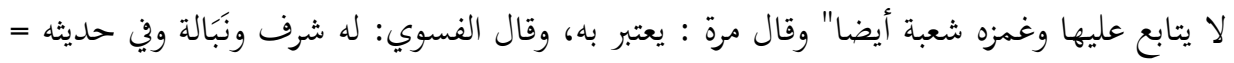


ـ قلت: ما صرّح أحد بتوثيقه إلا ابنُ سعد، وتوسّط فيه غير واحد كالثوري وأحمد والنسائي

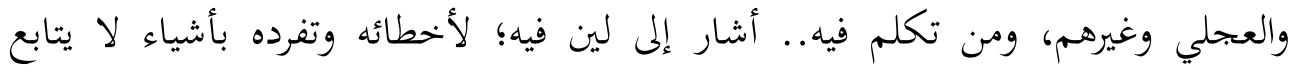

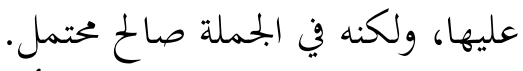

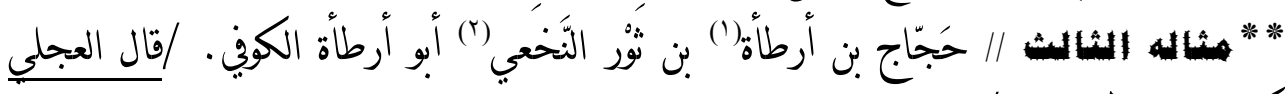

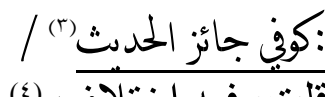

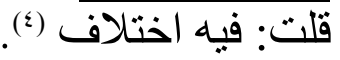

=لين، وقال الساجي: صدوق اختلفوا فيه، وقال أبو داود: صالح الحديث (نقل قولي الساجي وأبي

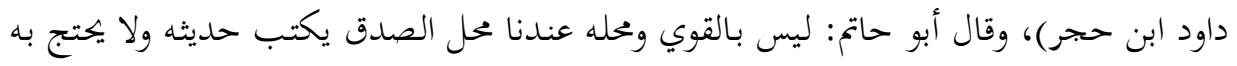

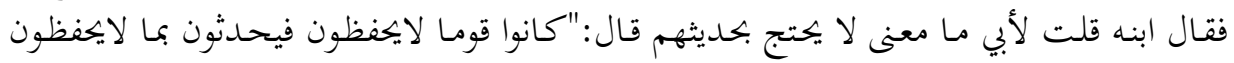

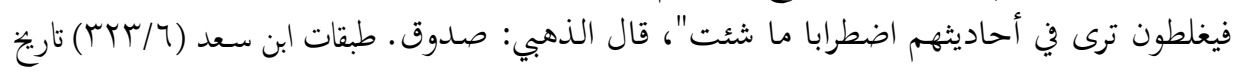

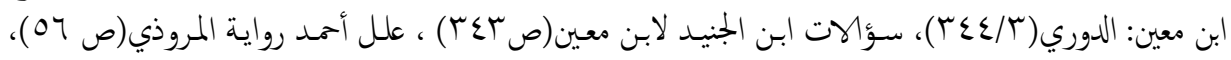

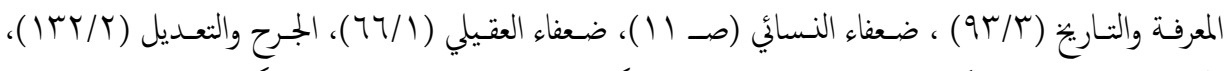

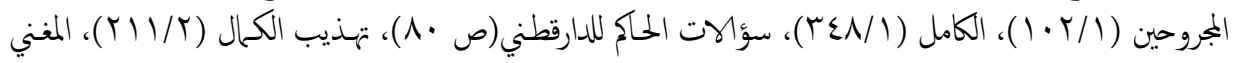

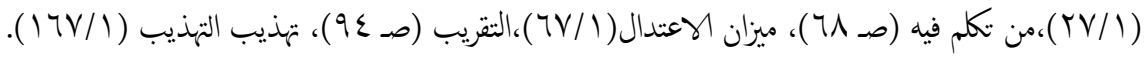

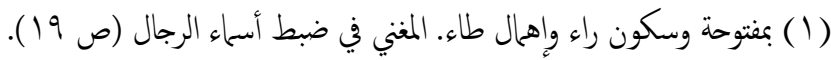

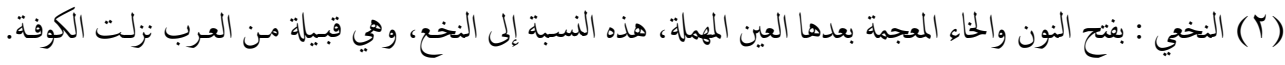

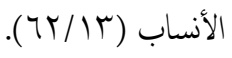

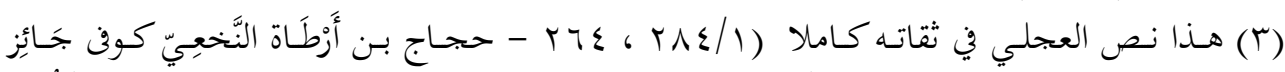

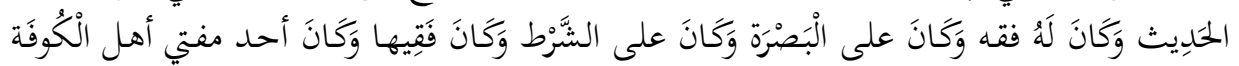

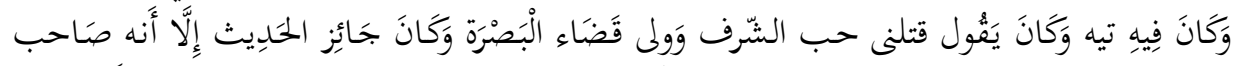

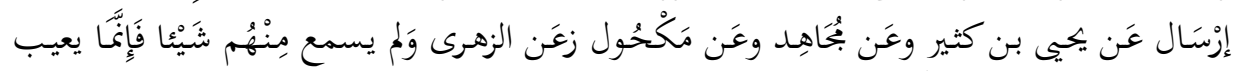

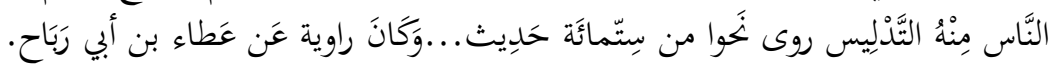

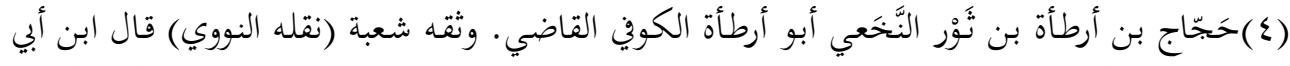

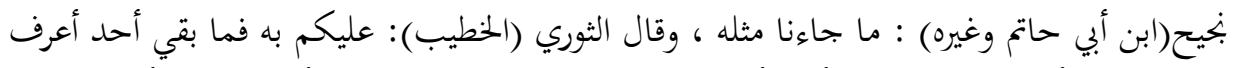

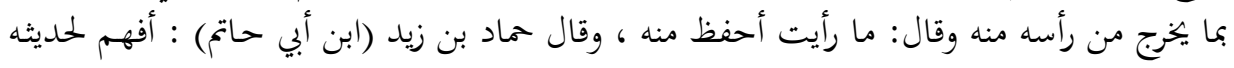

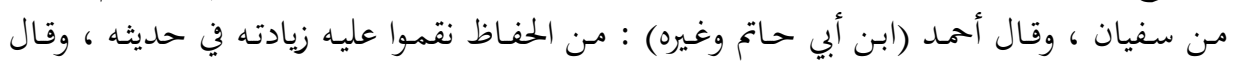

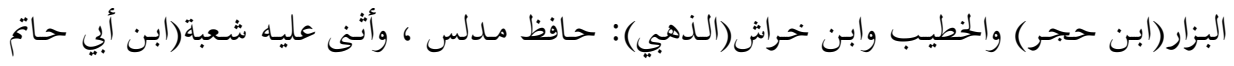

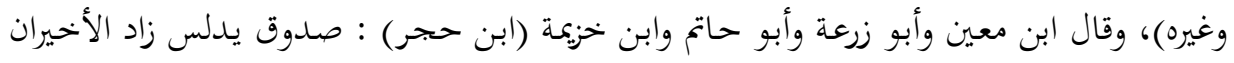

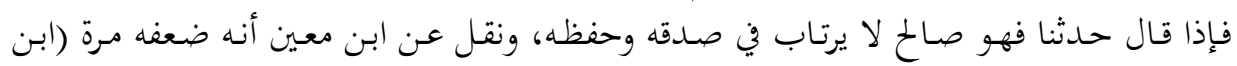

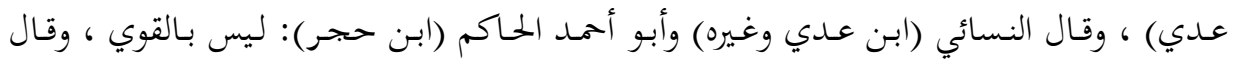

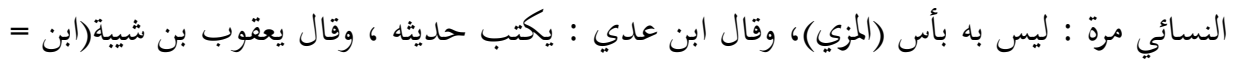




\section{وأنكروا عليه تدليسه وقيل هو في المرتبة الرابعة (').}

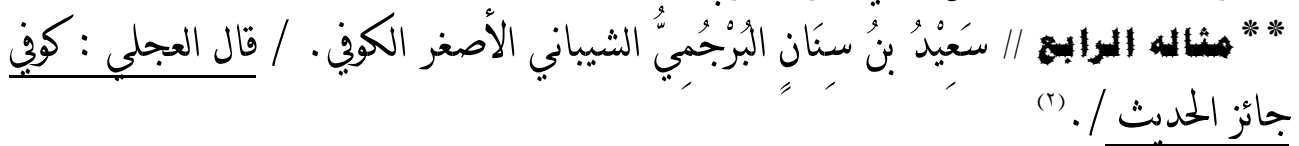

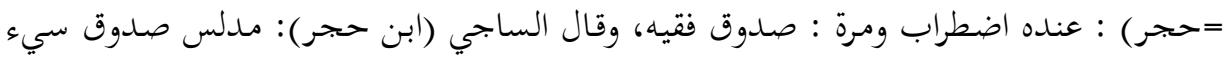

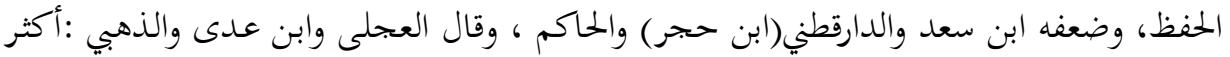

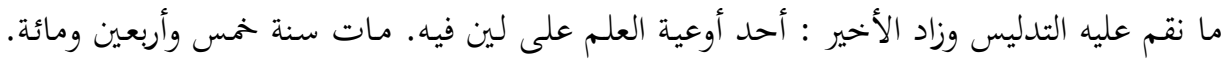

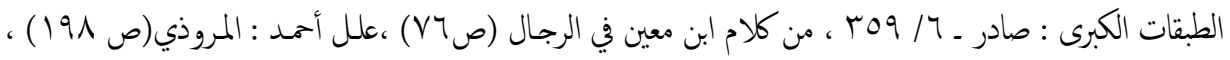

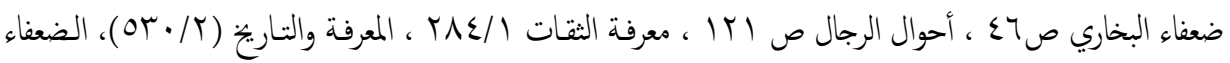

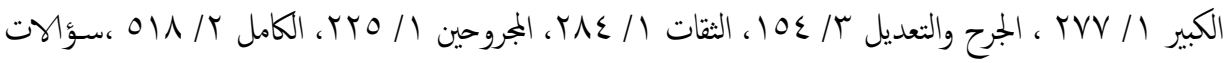

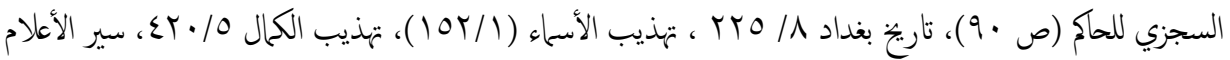

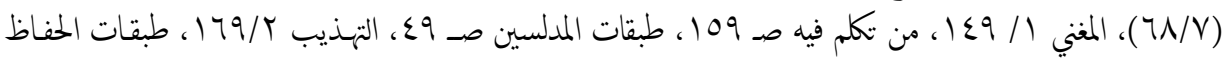
ص AV (1) الرابعة من المدلسين : من اتفق على أنه لا يحتج بشيء من حديثهم إلا بما صرحوا فيه بالسماع لكثرة تدليسهم على الضعفاء

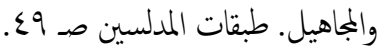

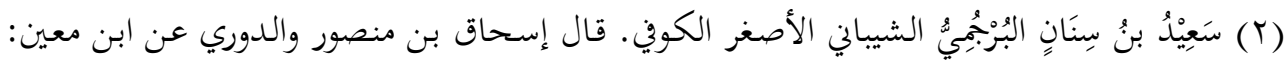

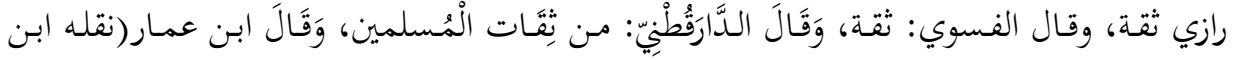

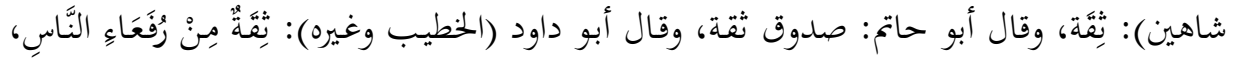

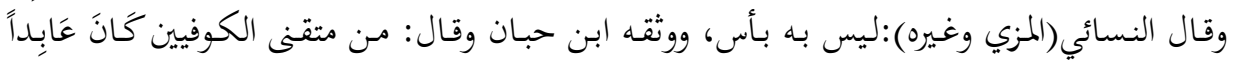

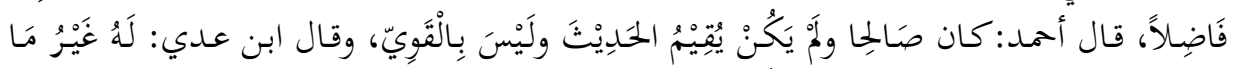

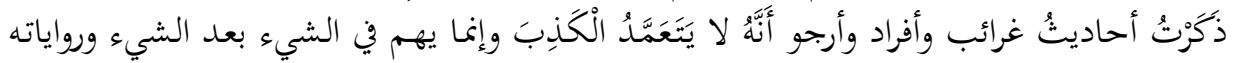

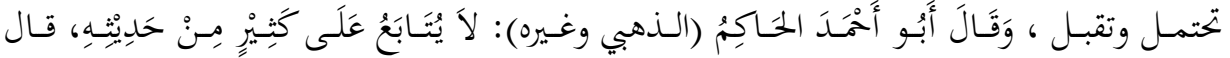

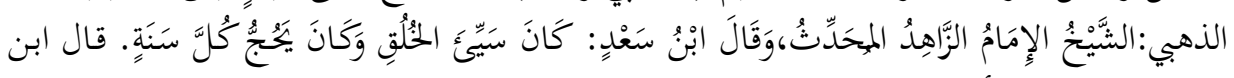

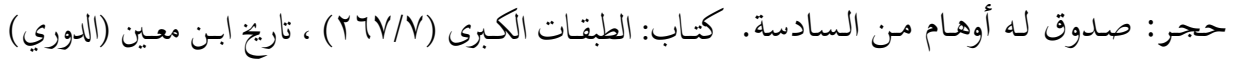

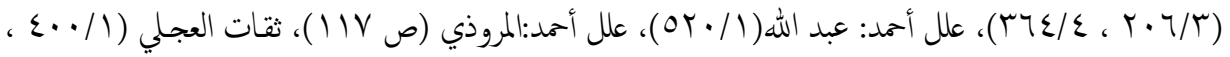

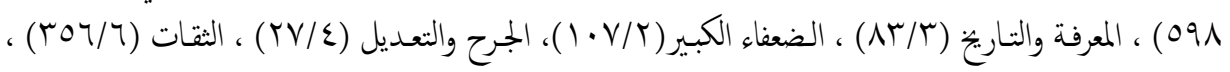

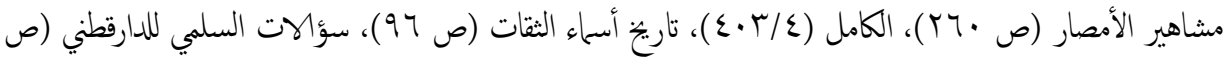

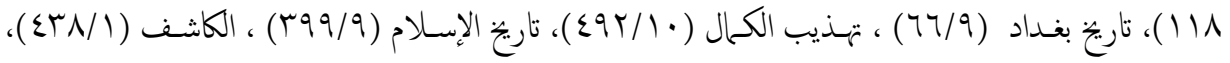

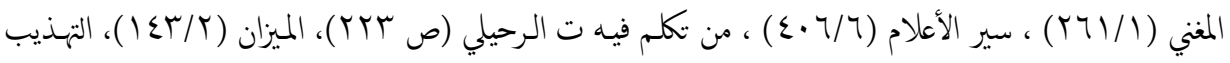

( ) ( ) )، التقريب(ص (YTV). 

القول الحثيث في بيان مصطلح ( جائز الحديث) عند أئمة الحديث

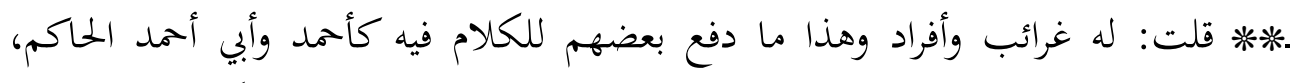

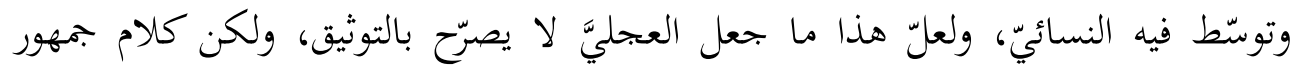

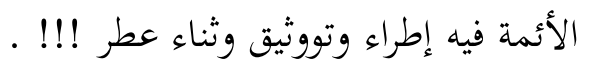

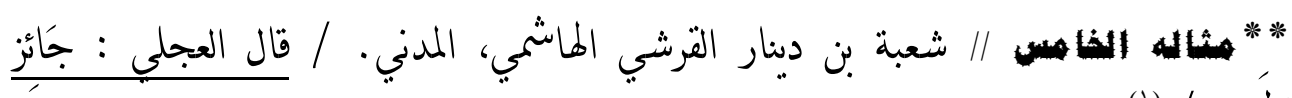

(1) الحمدثبث

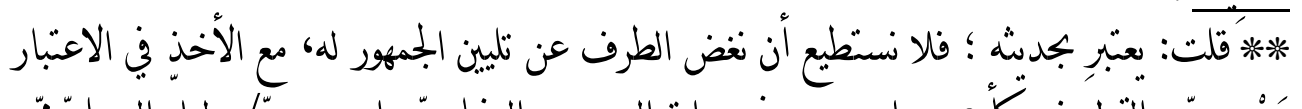

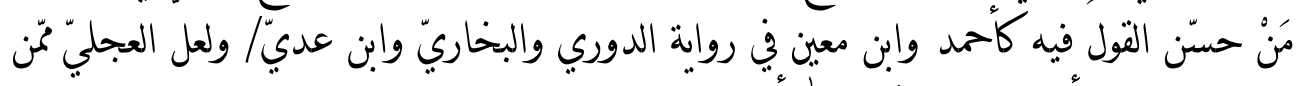

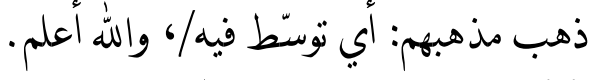

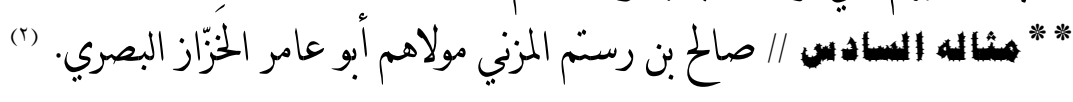

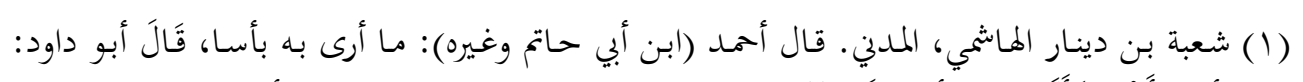

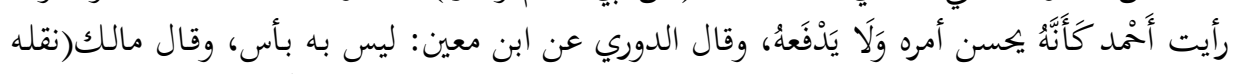

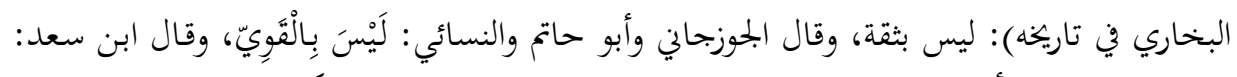

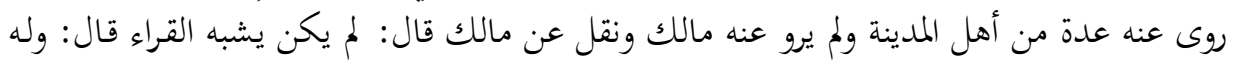

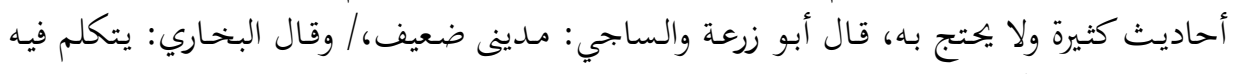

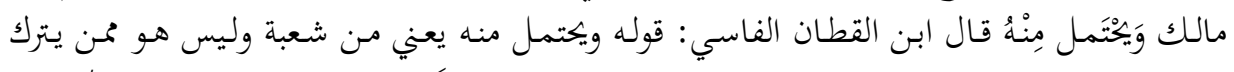

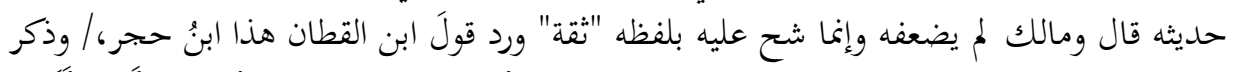

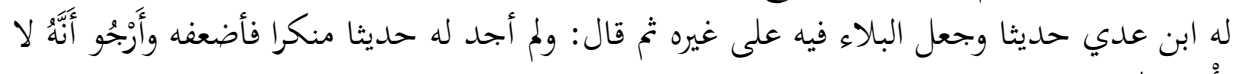

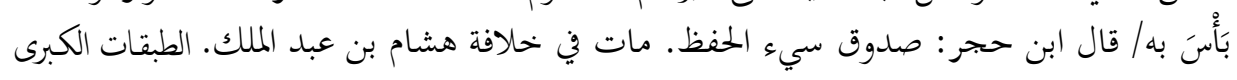

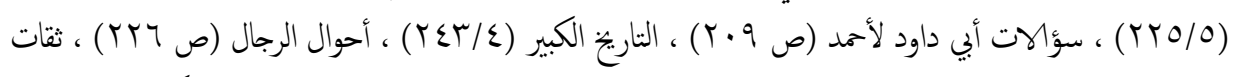

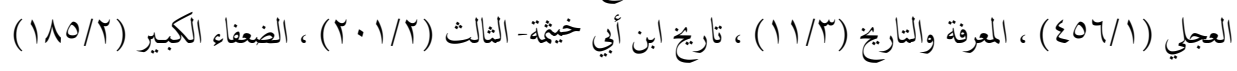

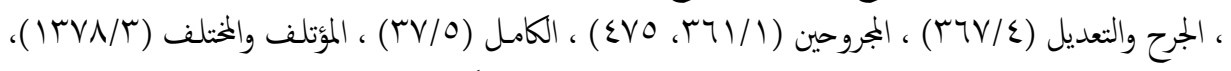

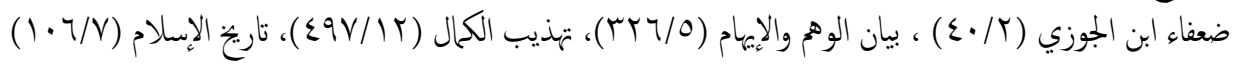

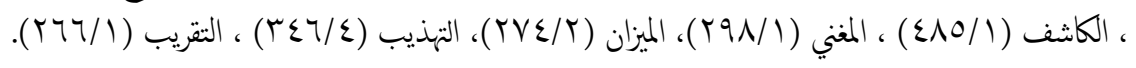

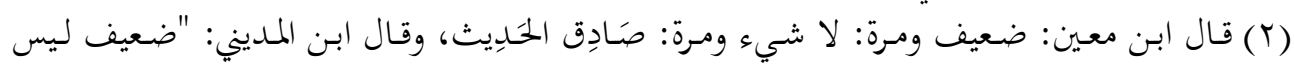

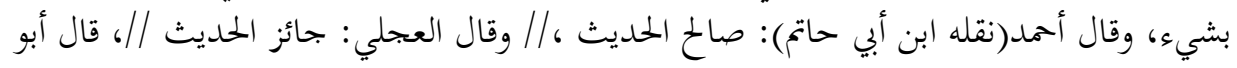

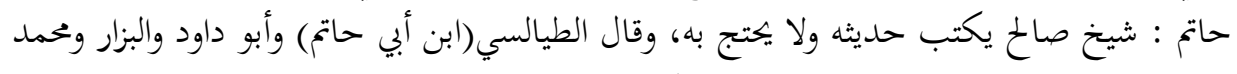

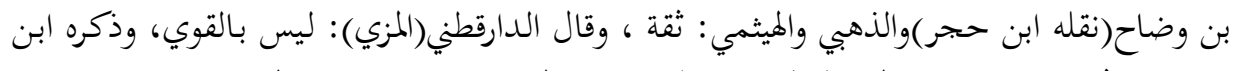

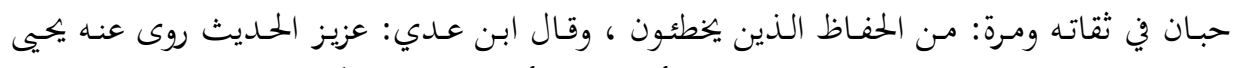

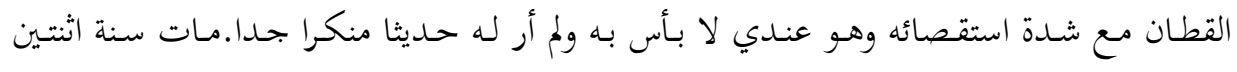

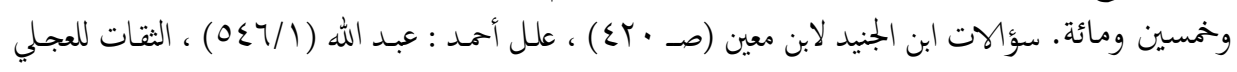

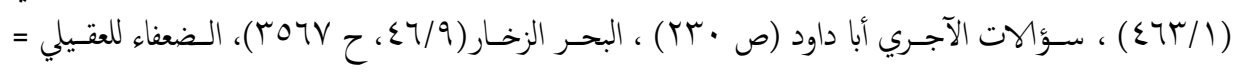


ثقاث: قلت: له أخطاء كما بيّن ابنُ حبان مع وصفه بالحفظ، وعبّر ابنُ عدي بأنه ليس له ما

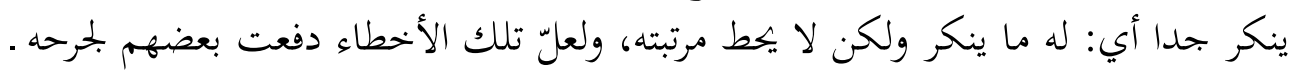

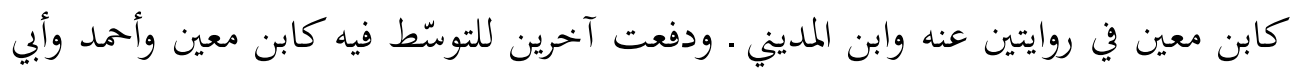

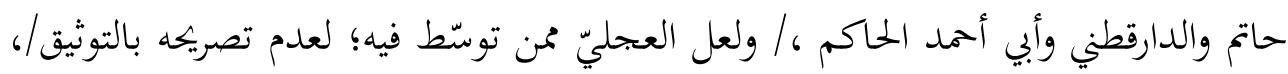
وهذا لخّصه الذهبي بقوله: حديثه لعله يبلغ خمسين حديثاً وهو كما قال أحمد.

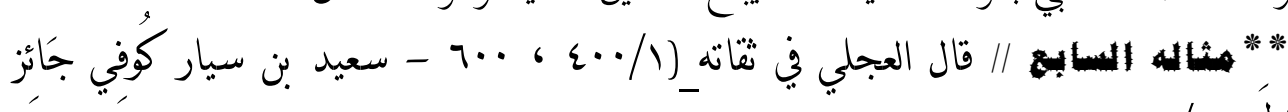
الحدبث/ قلت": لم أقف له على ترجمة ، ولعله هو "سعيد بن سنان" ؛ لتطابق قول العجلي فيه ، (1).

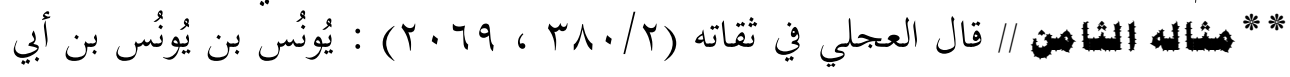

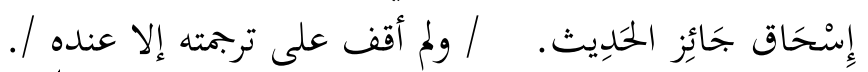

\section{:}

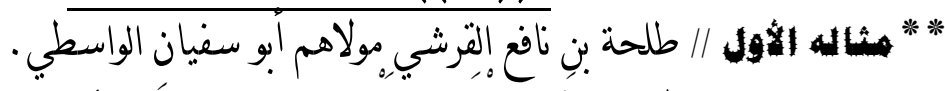

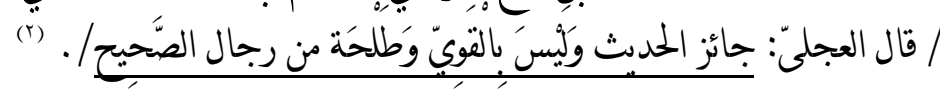

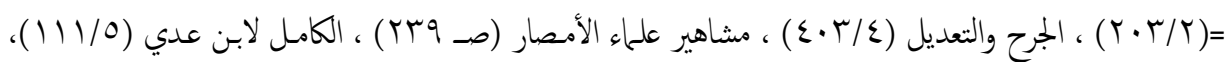

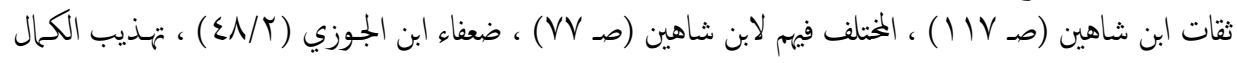

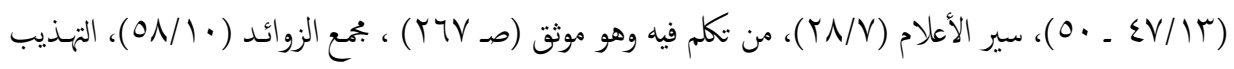

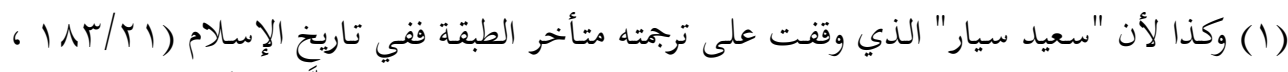

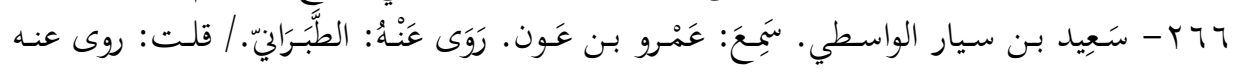

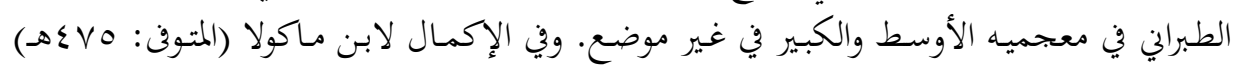

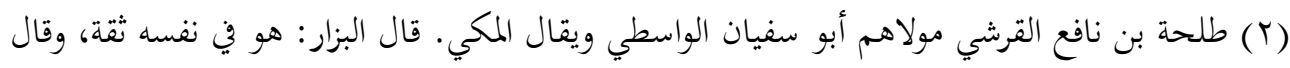

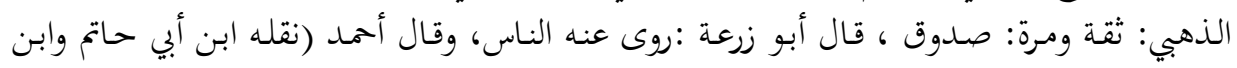

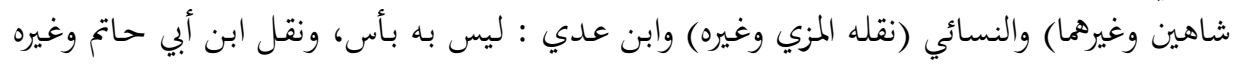

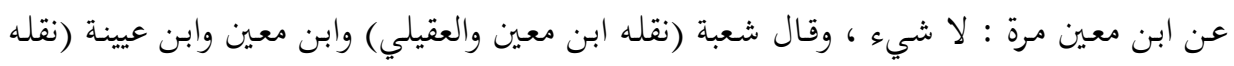

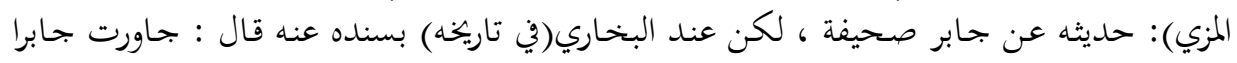

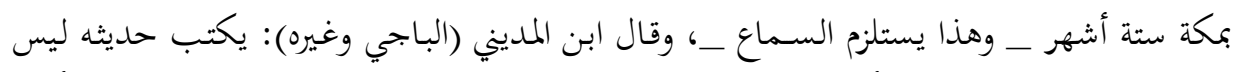

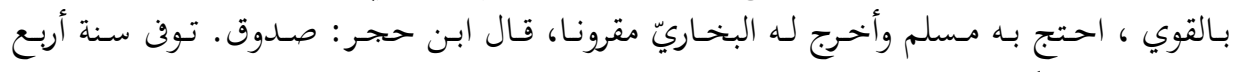

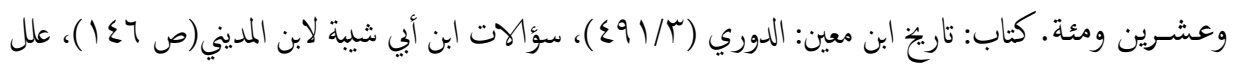

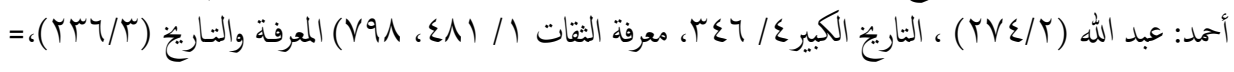




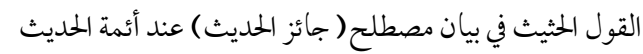

*ق* قلت: صدوق ـ إن لم يكن ثقة ـ مدلس من الثالثة، تُكلّم في روايته عن جابر والأرجح

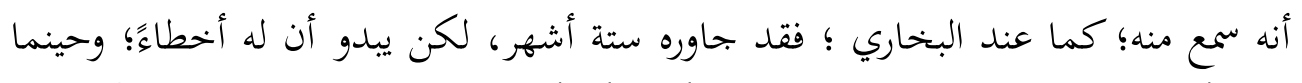

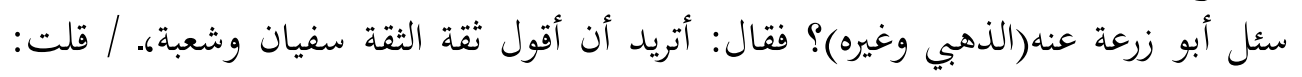

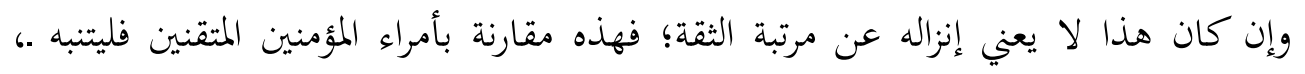

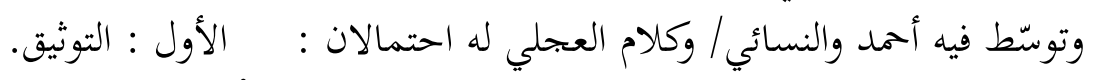

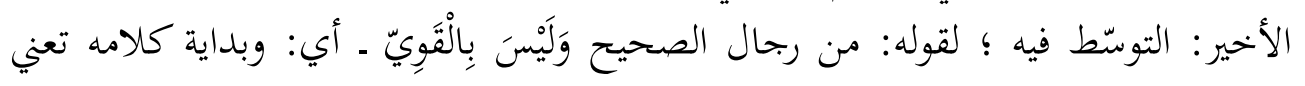

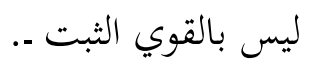

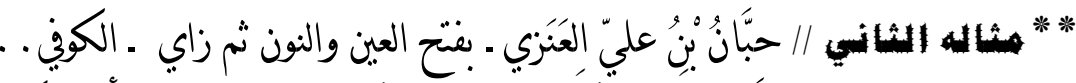

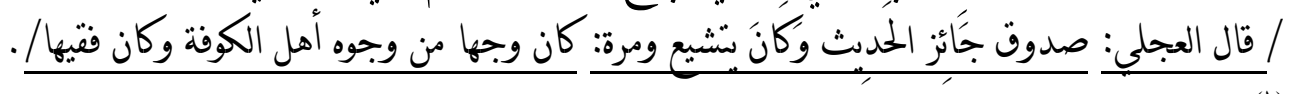

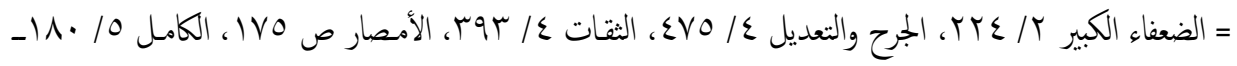

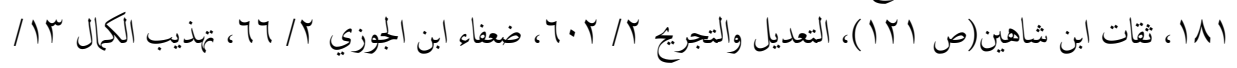

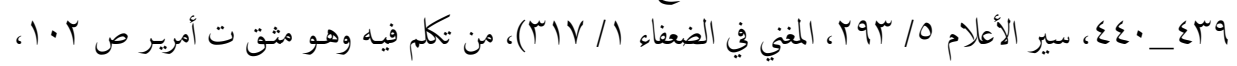

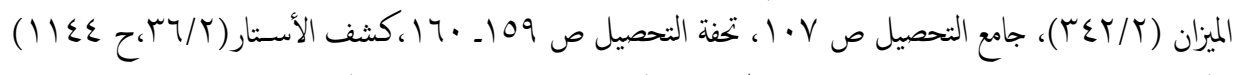

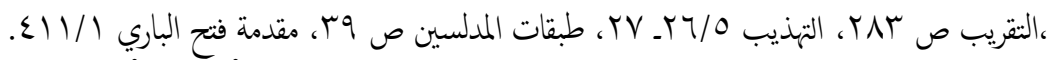

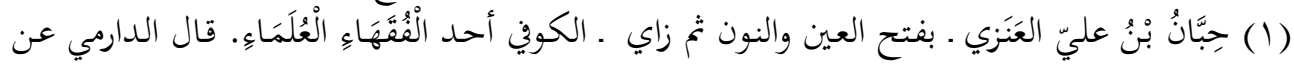

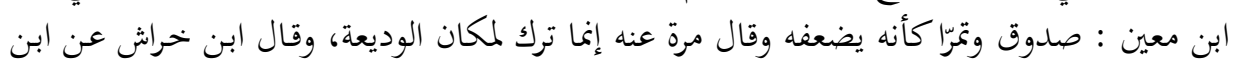

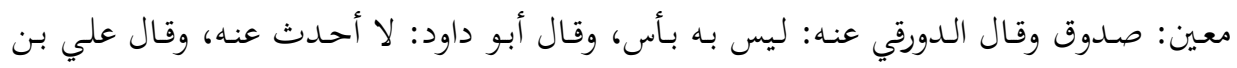

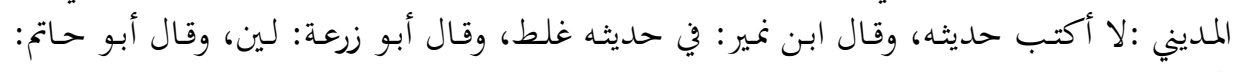

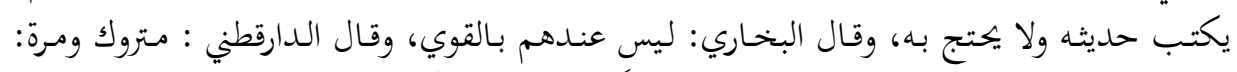

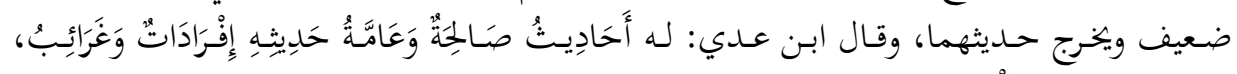

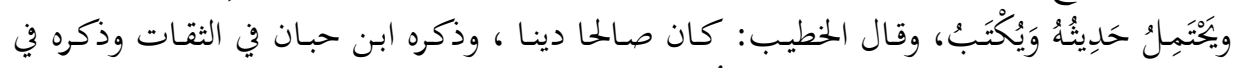

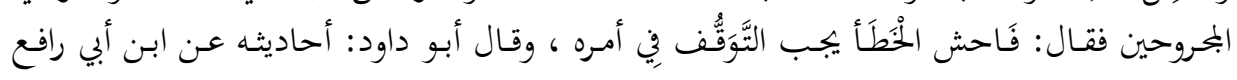

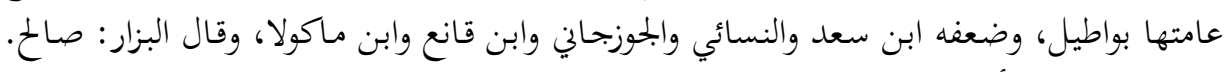

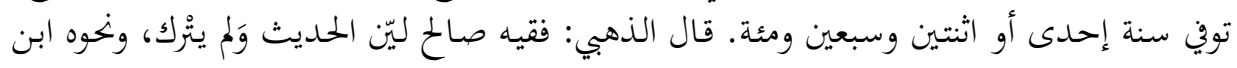

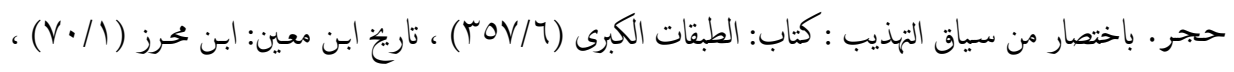

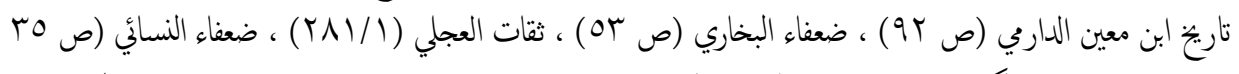

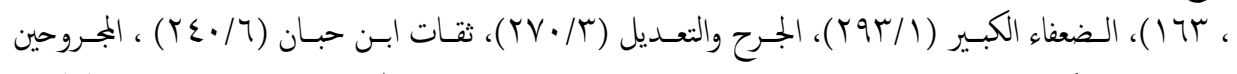

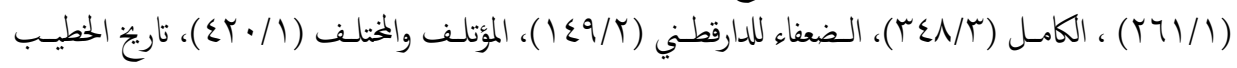

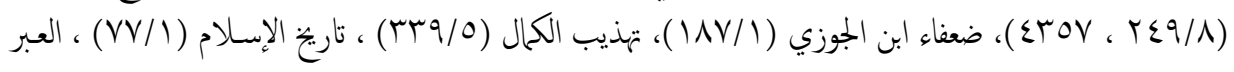

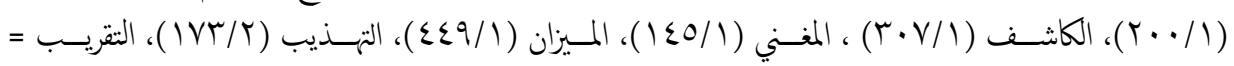




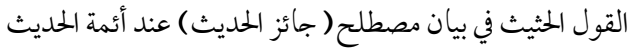

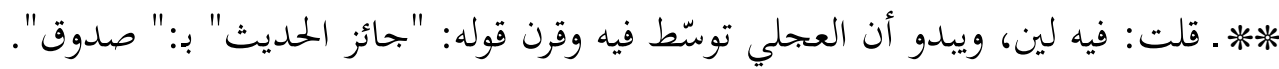

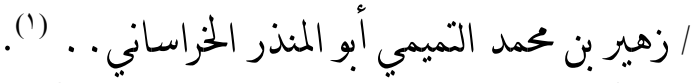

قال العجلي في ثقاته ( بأس به كما سبق.

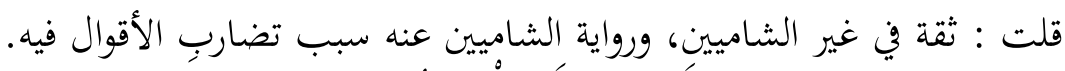

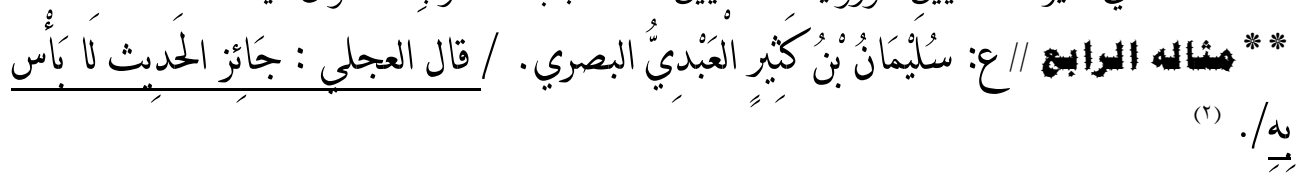

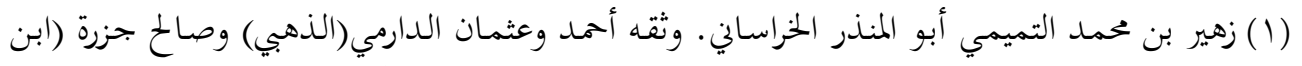

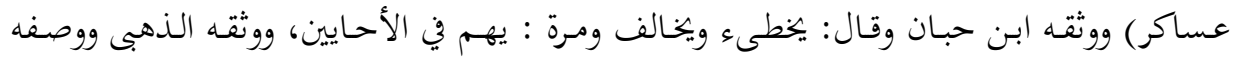

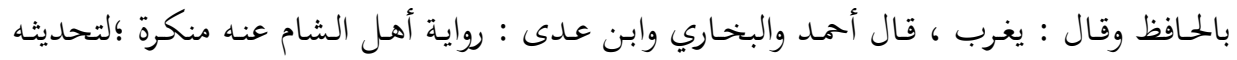

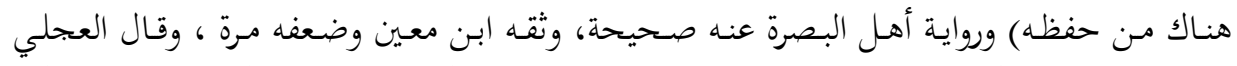

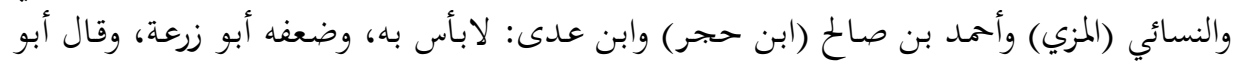

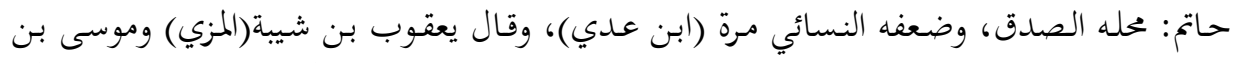

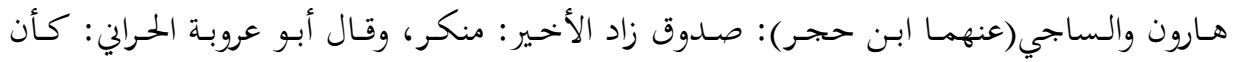

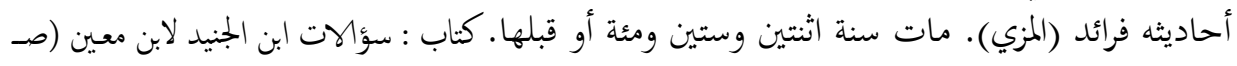

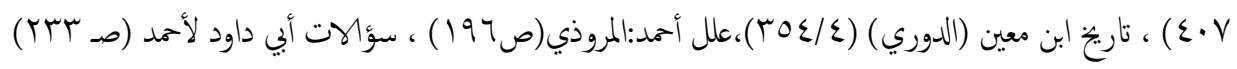

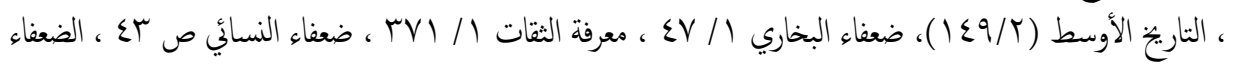

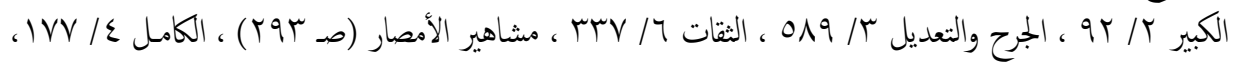

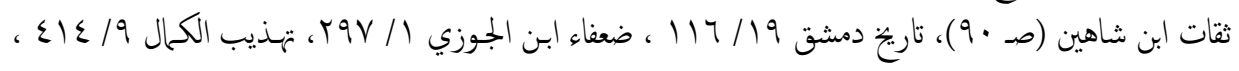

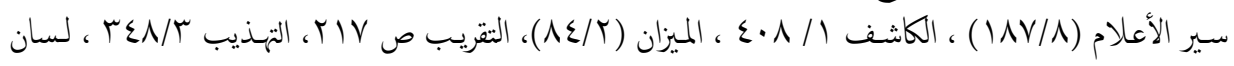

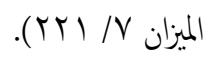

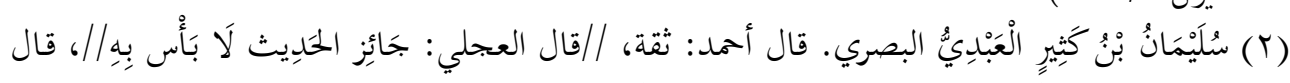

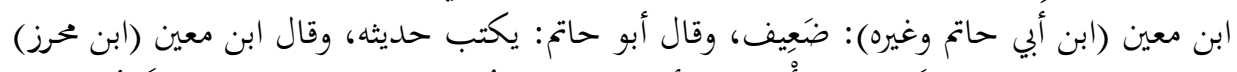

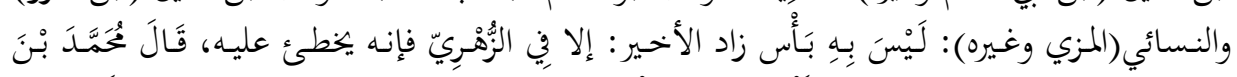

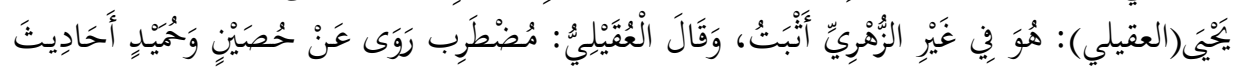

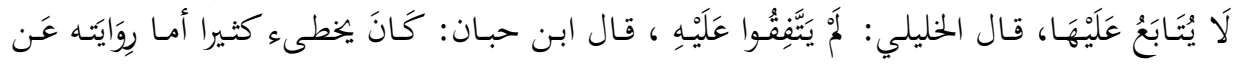

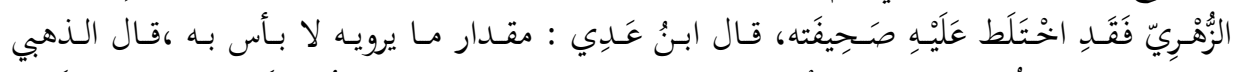

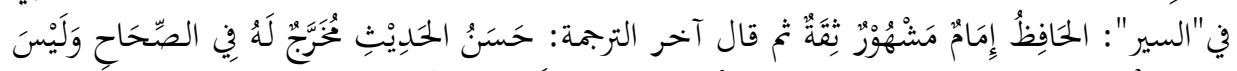

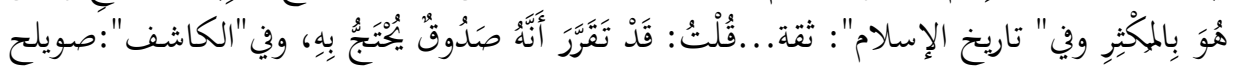

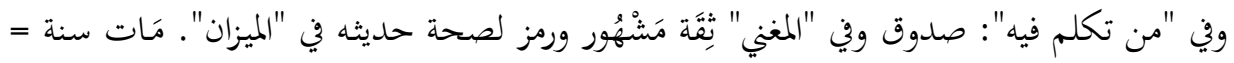




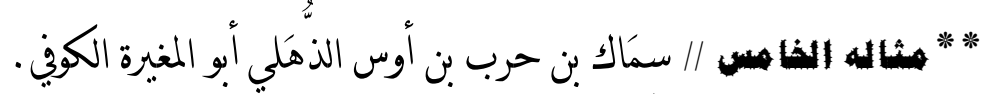

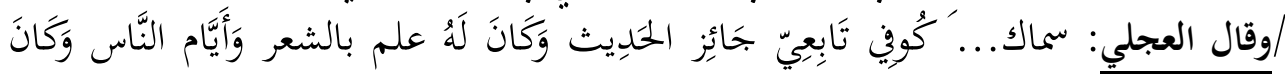

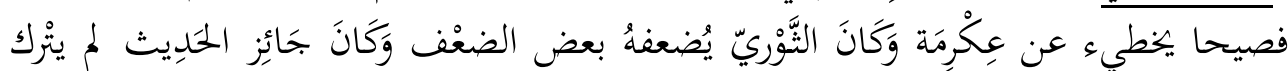

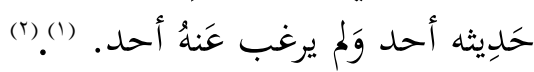

=

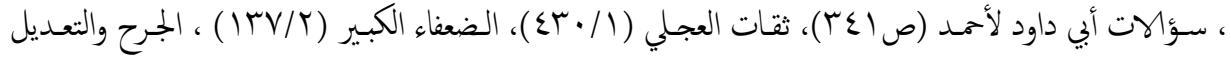

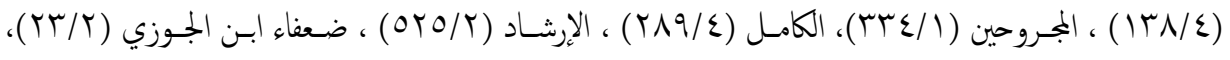

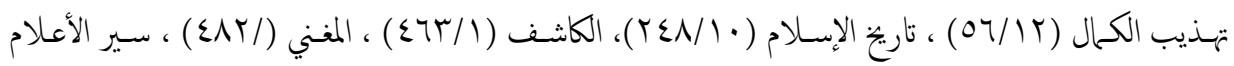
(Y)

** قلت: الناظر في ترجمته يتبين أن حديثه عن الزهريّ منه ما هو صالح ومنه ما أخطأ فيه وبقية حديثه لا

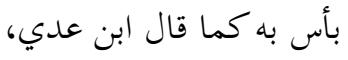

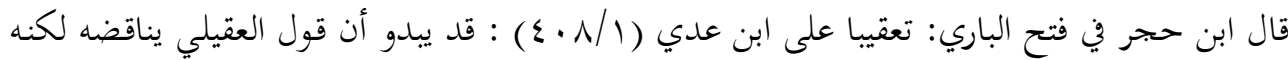

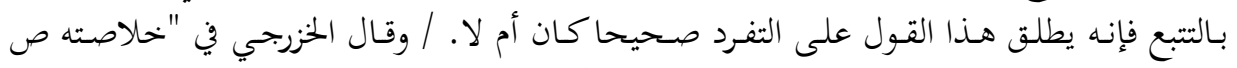

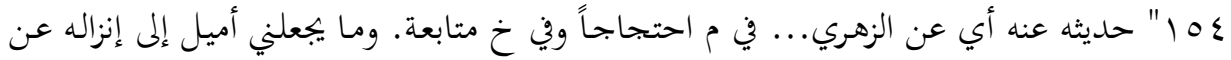

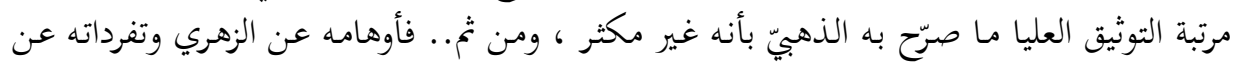

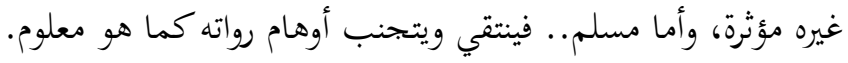

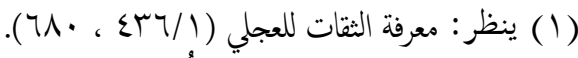

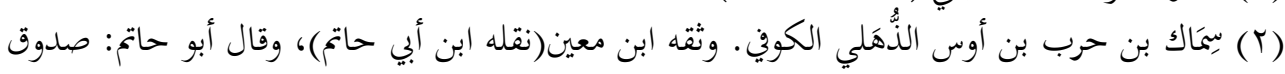

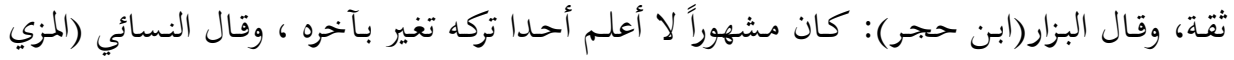

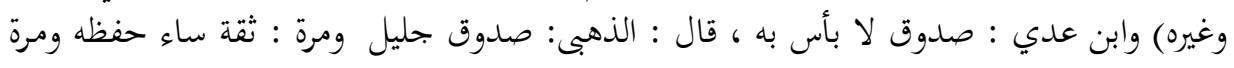

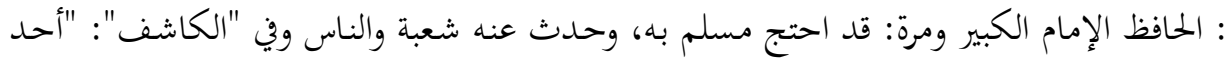

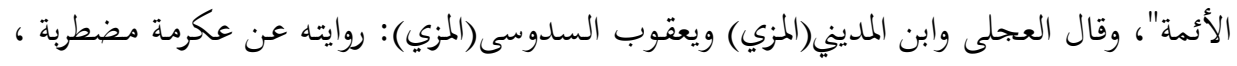

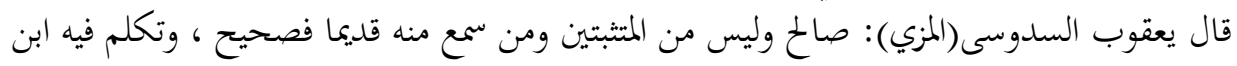

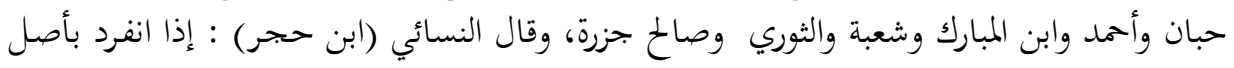

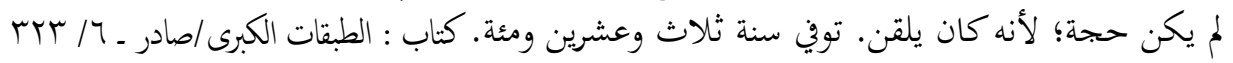

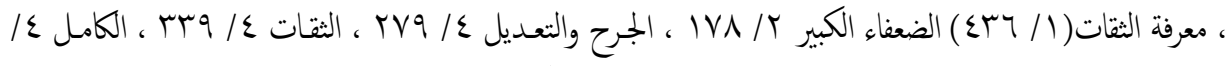

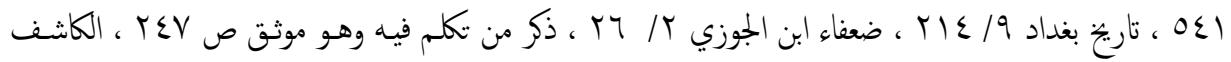

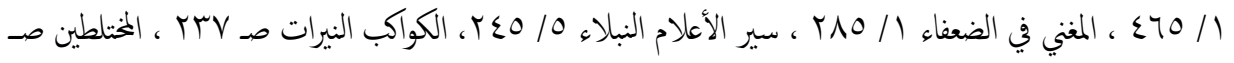

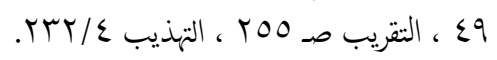




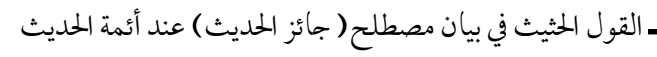

*ق*ق قلت: له أخطاء؛ لاضطرابه وسوء حفظه، وتغيّره بآخره وقبوله التلقين كما بيّن النسائي، وقد بيّن العجلي أنه جائز الحديث يكتب لاضط حديثه فيبدو أنه توسّط فيه كغيره من الأئمة.

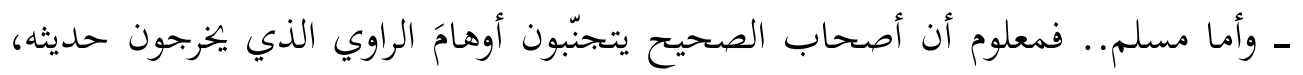
والله أعلم.

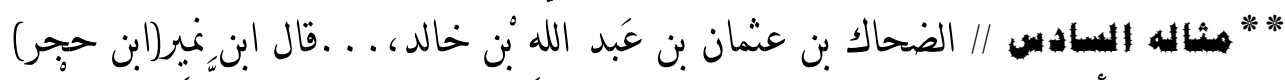

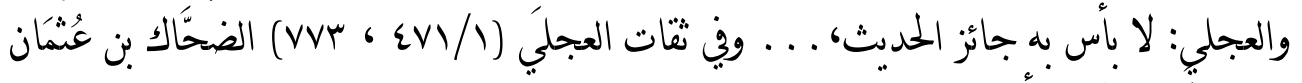

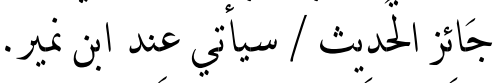

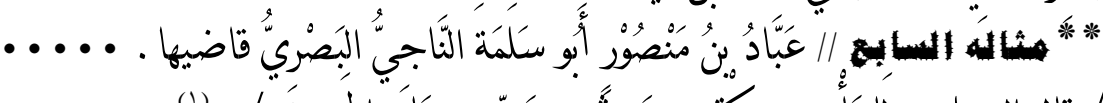

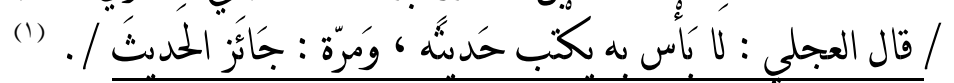

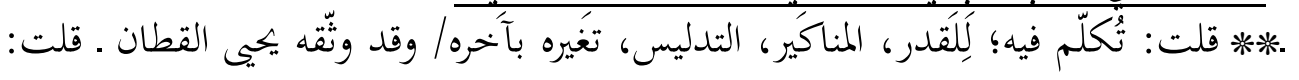

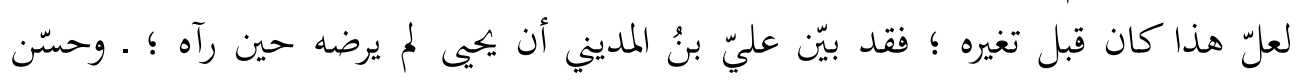

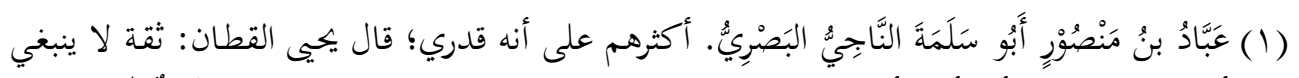

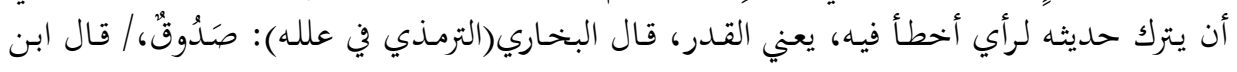

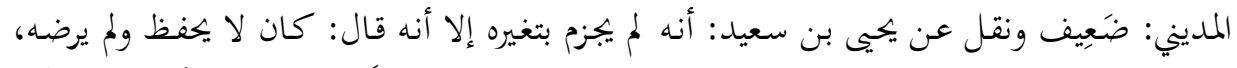

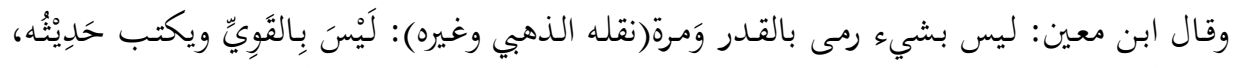

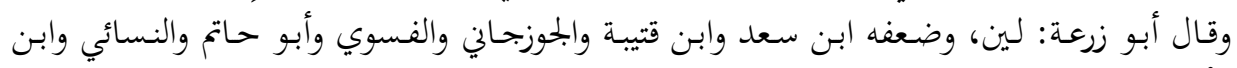

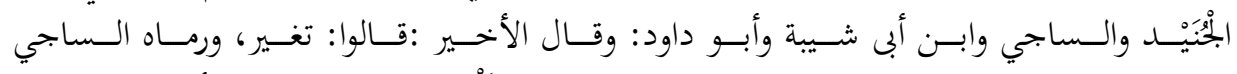

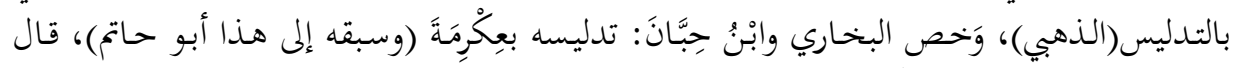

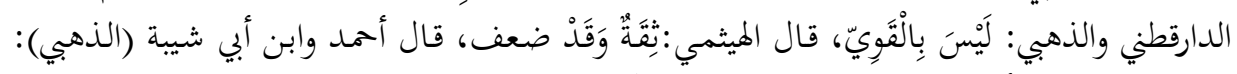

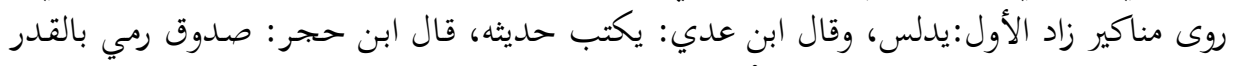

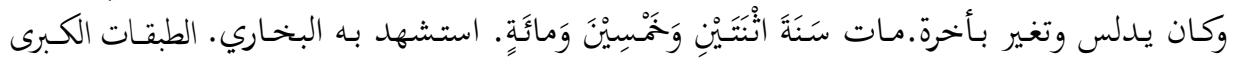

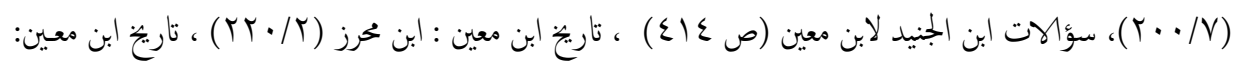

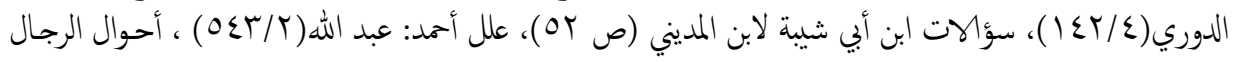

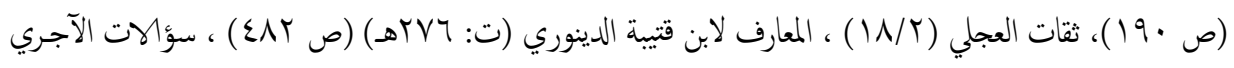

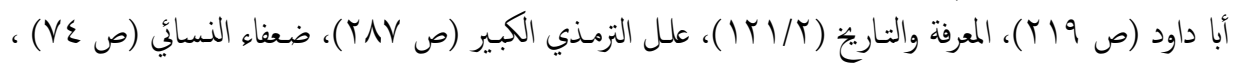

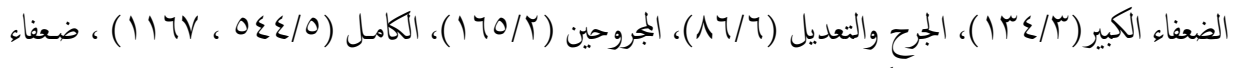

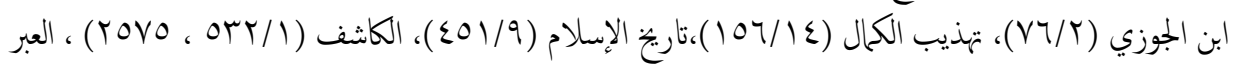

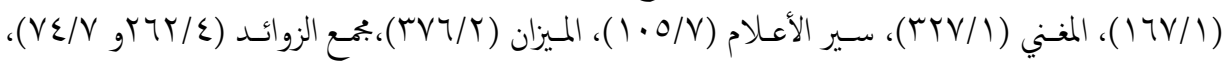

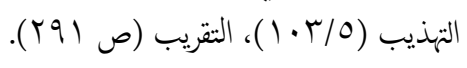




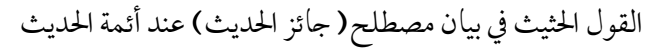

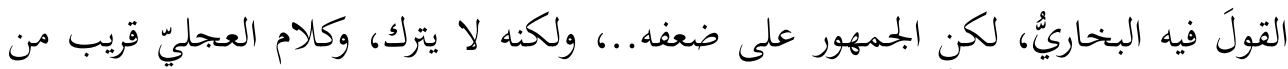

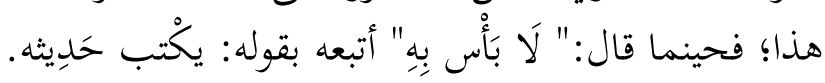

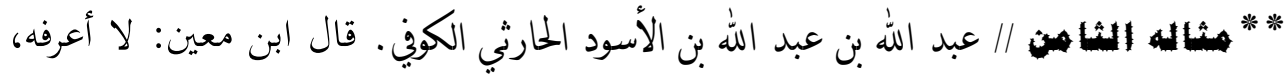

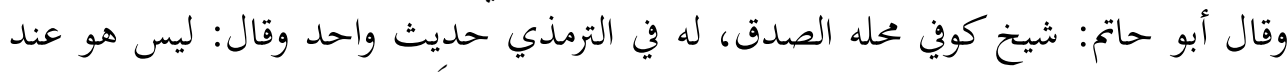

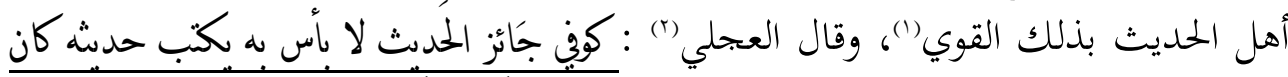
بلي السلطان.

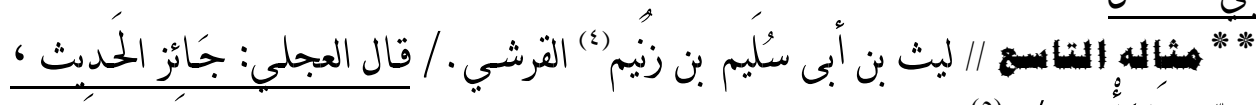

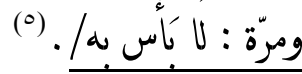

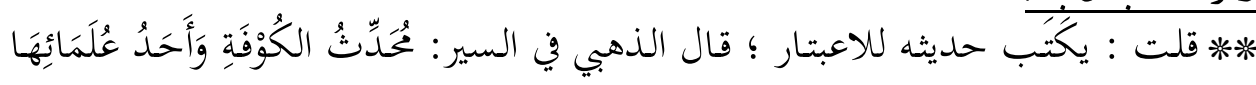

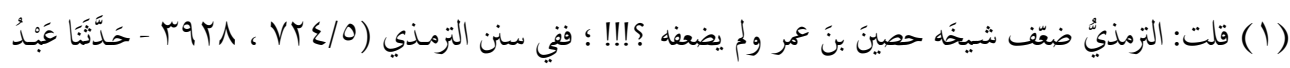

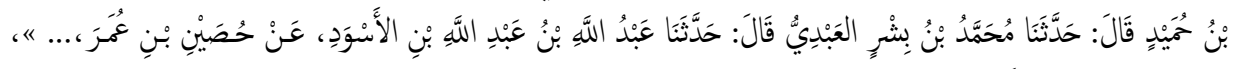

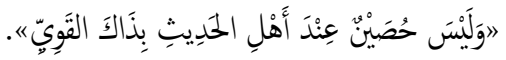

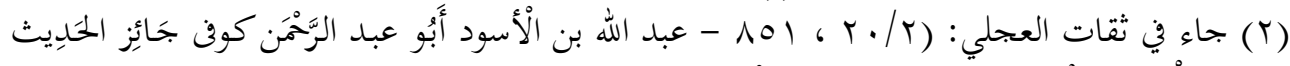

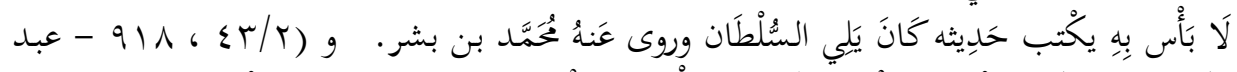

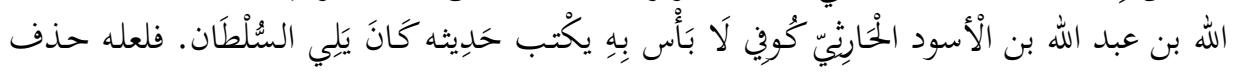
اسم أبيه مرة.

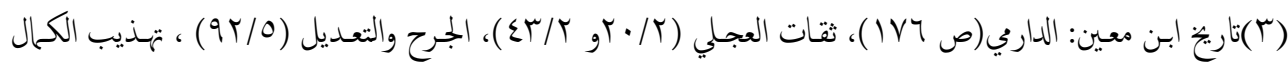

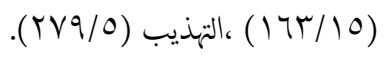

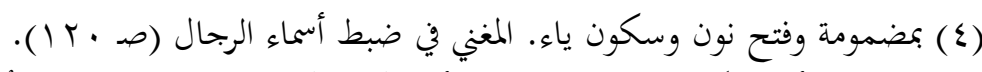

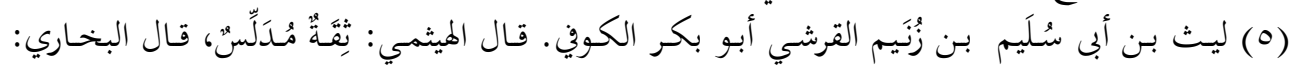

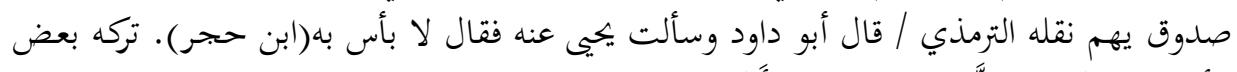

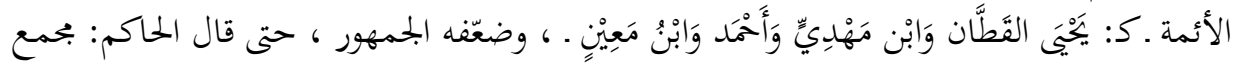

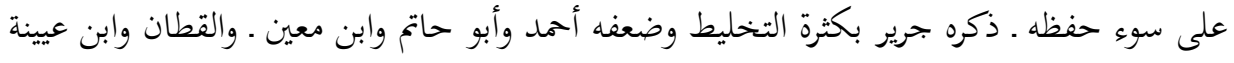

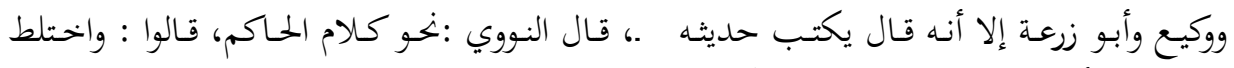

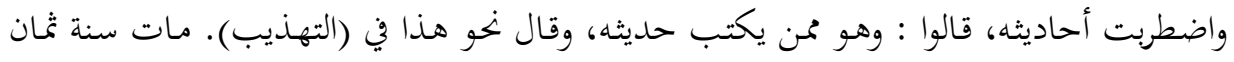

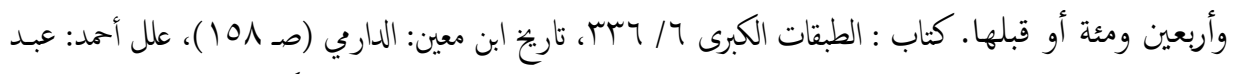

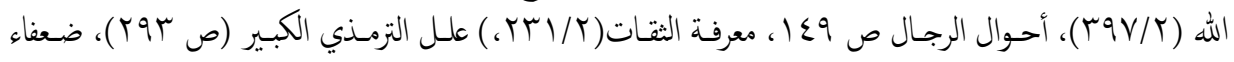

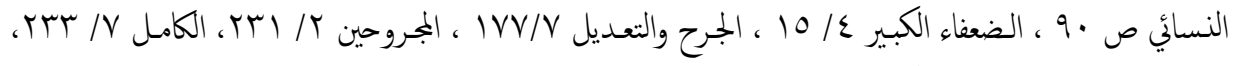

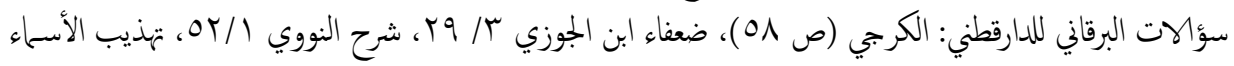

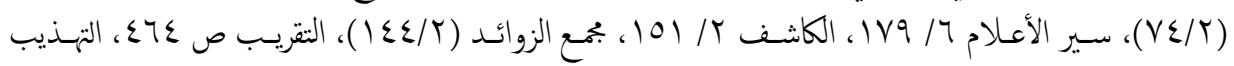
1 

القول الحثيث في بيان مصطلح ( جائز الحديث) عند أئمة الحديث

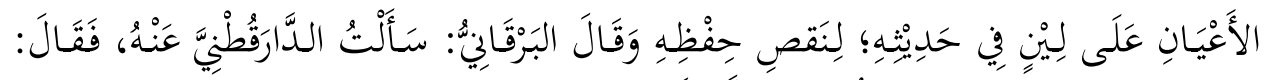

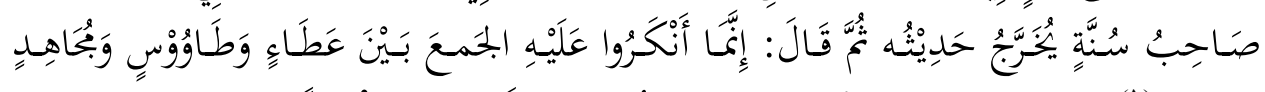

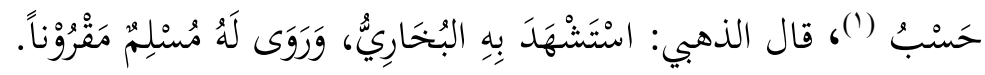

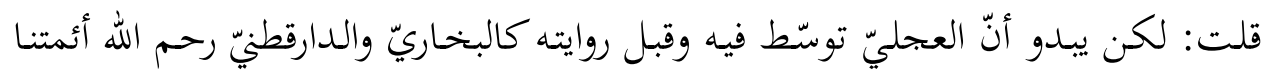
جمبعا.

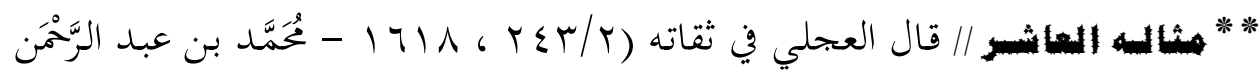

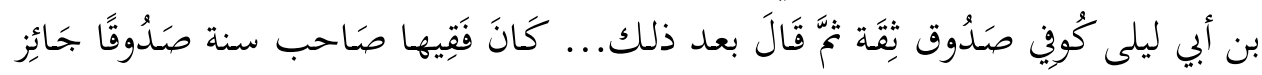

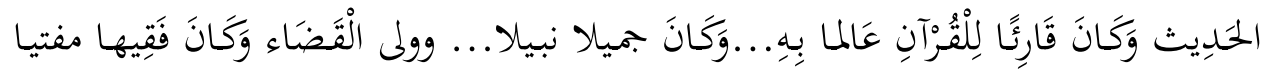

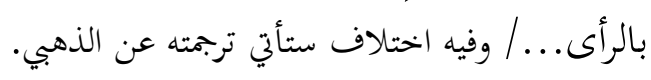

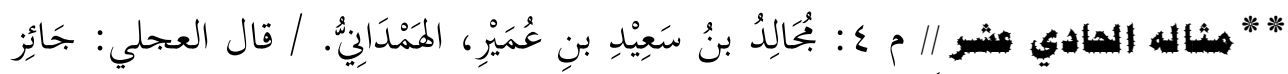

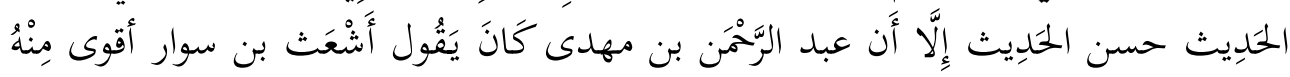

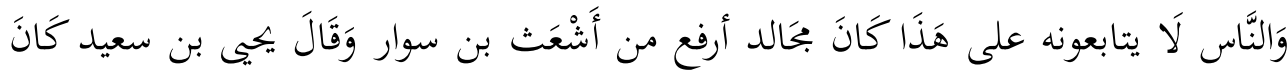

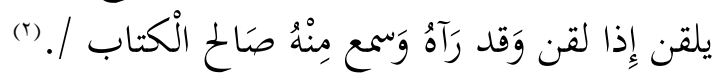

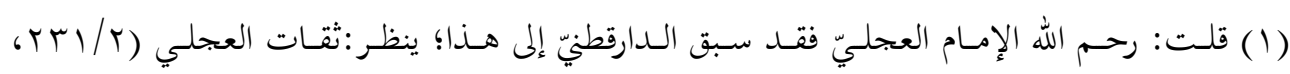

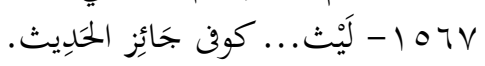

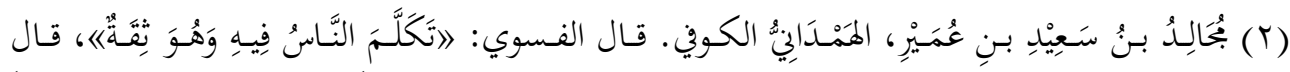

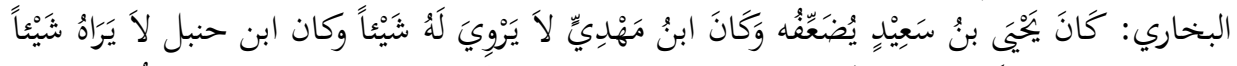

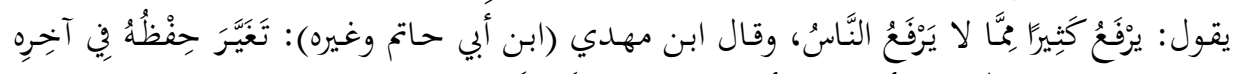

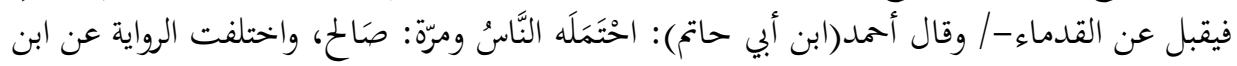

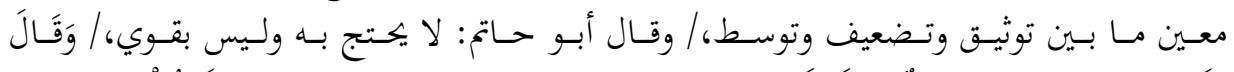

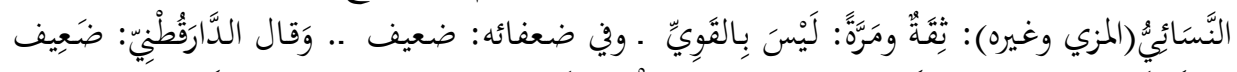

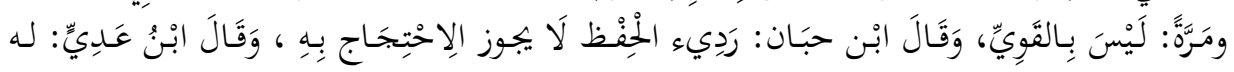

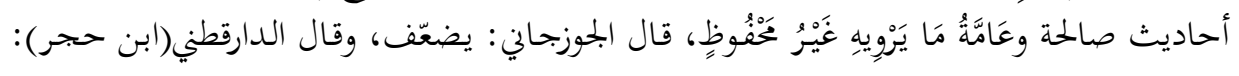

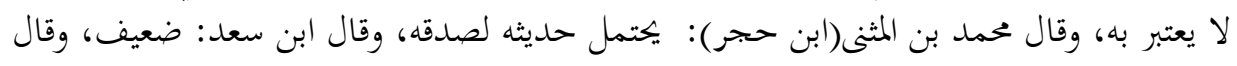

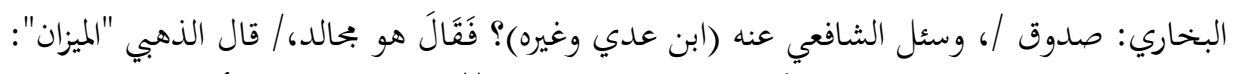

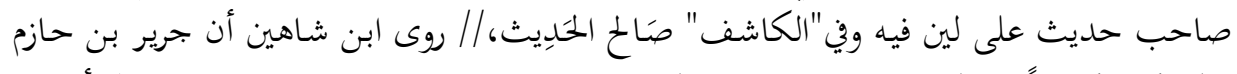

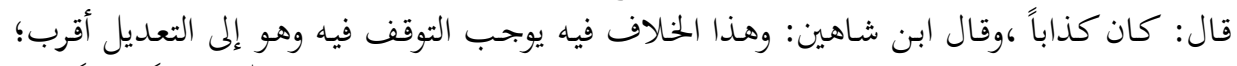

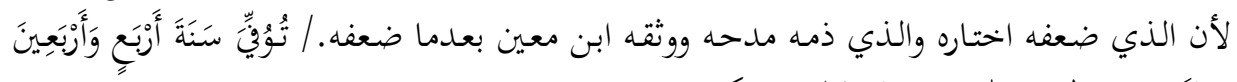

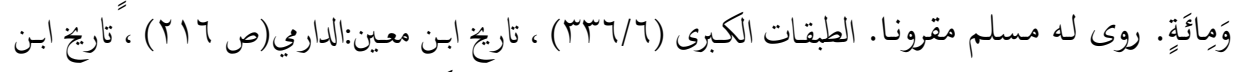

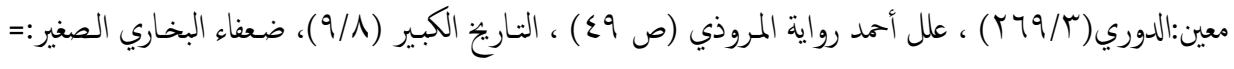




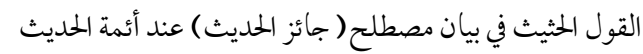

. قلت: يكتب حديثه للاعتبار، لكن يبدو أن مرتبه عند العجلي أرقى من هذا ؛ فهو

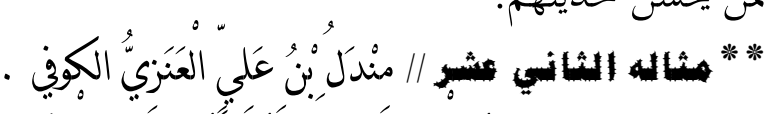

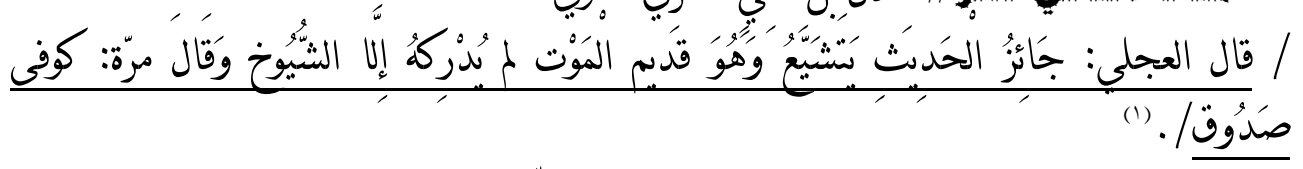

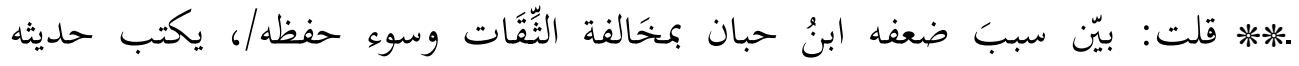

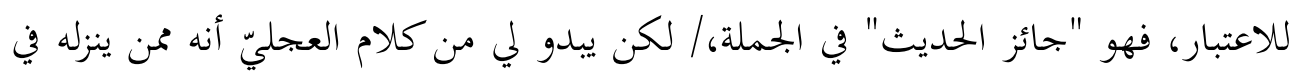
درجة من حديثُه حسن/ والله أعلم.

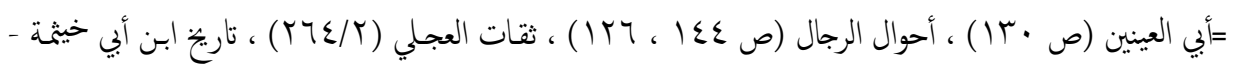

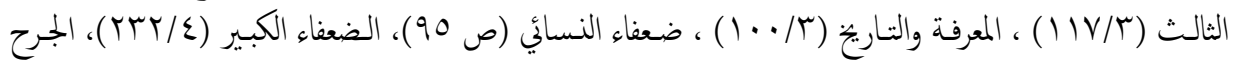

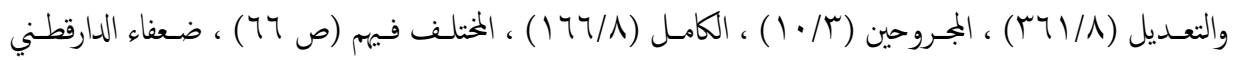

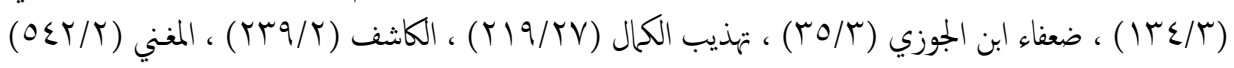

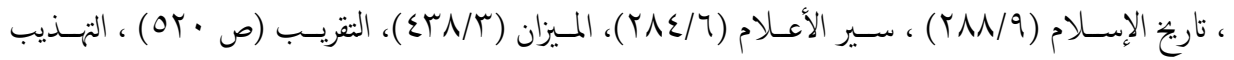

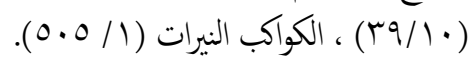

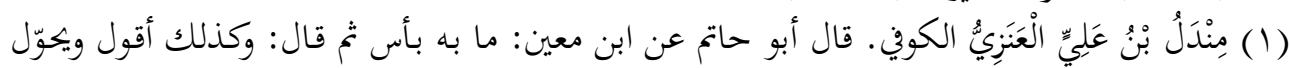

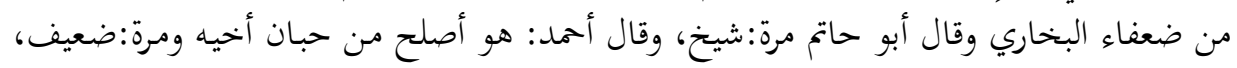

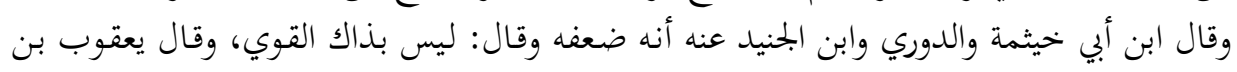

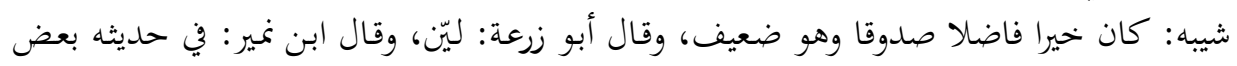

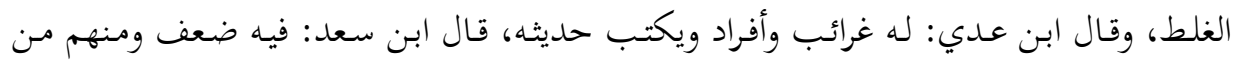

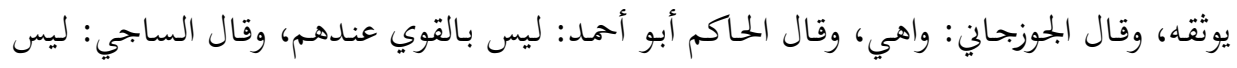

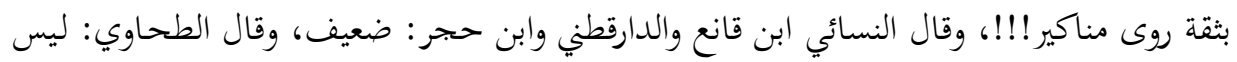

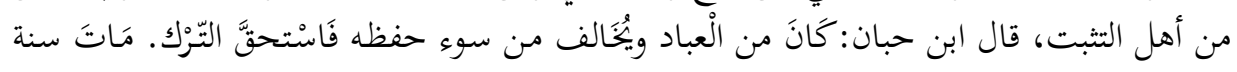

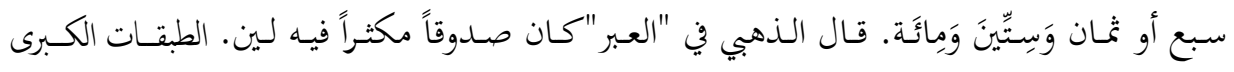

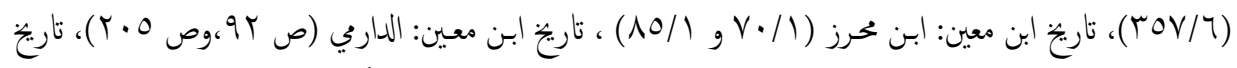

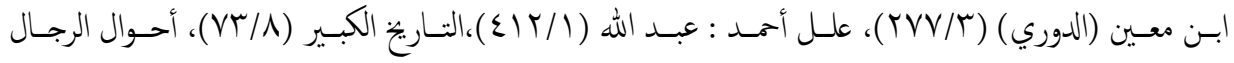

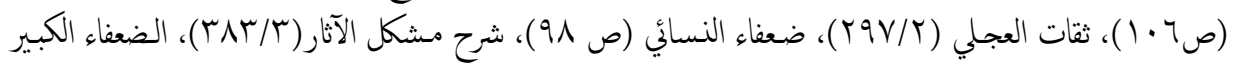

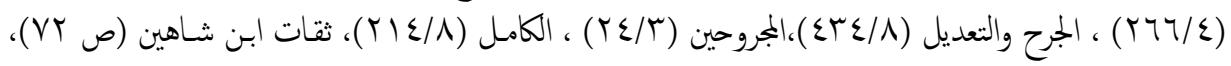

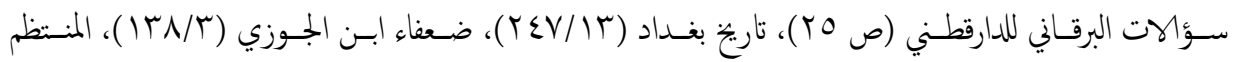

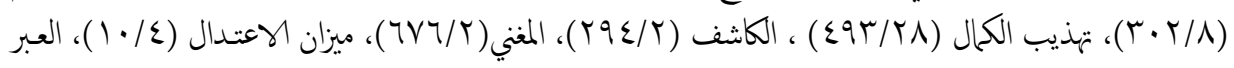

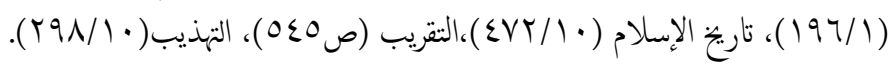




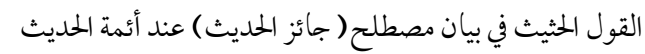

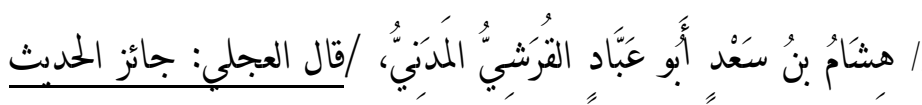

• قلت: في حفظه شيء، وهو دائر بين من حديثه في مرتبة الحسن أو من يخرج حديثه

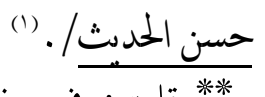

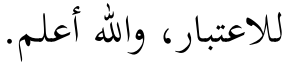

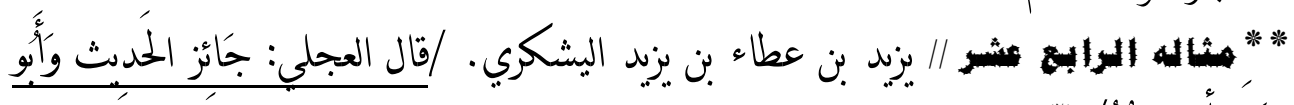

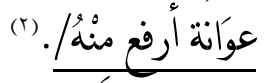

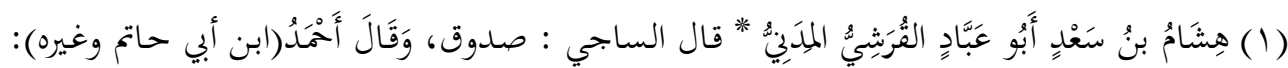

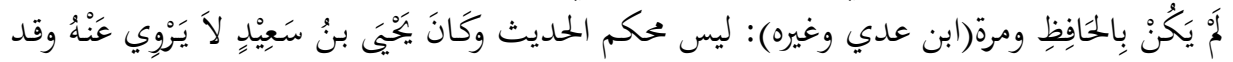

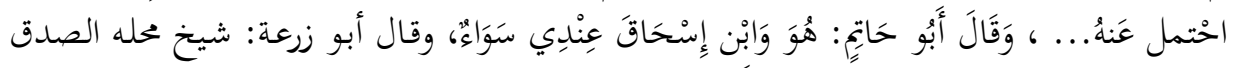

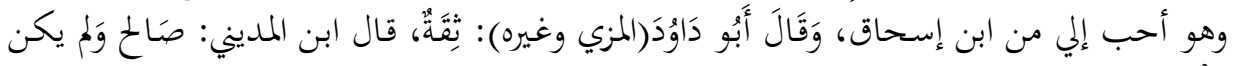

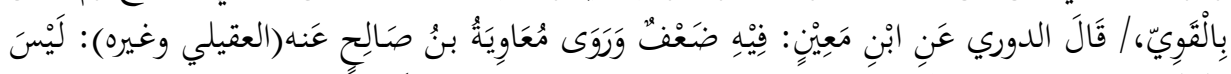

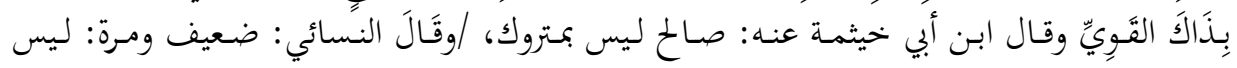

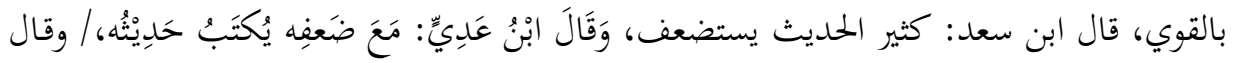

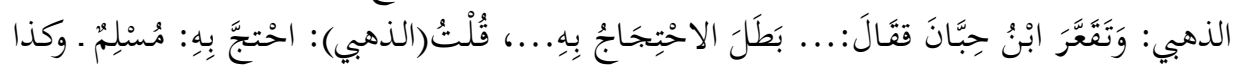

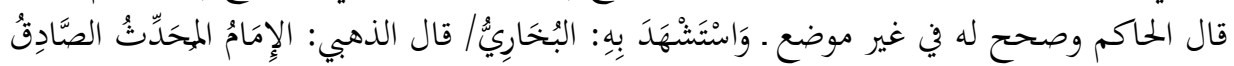

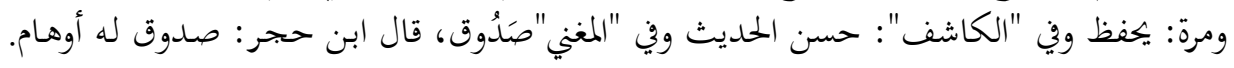

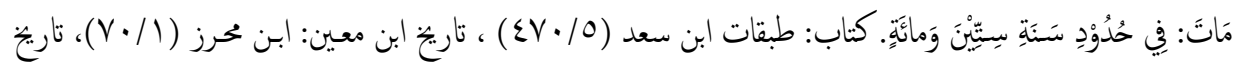

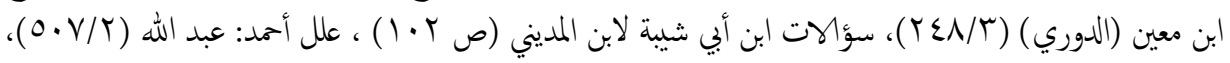

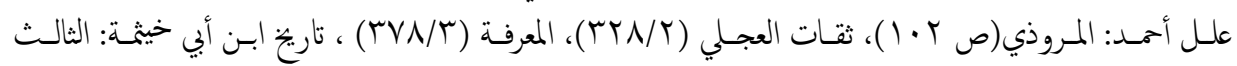

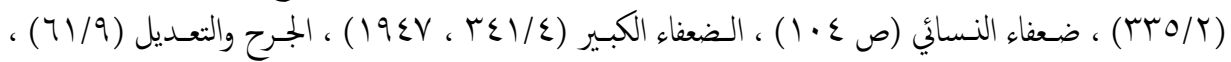

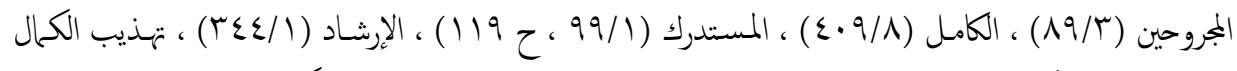

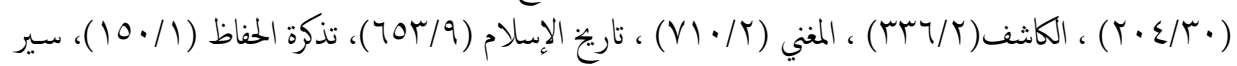

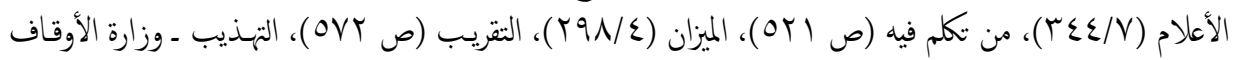

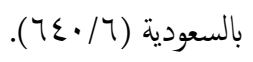

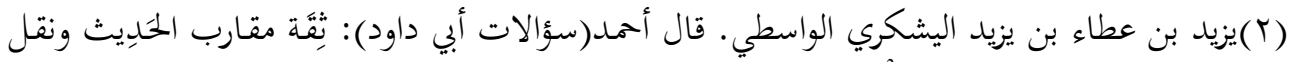

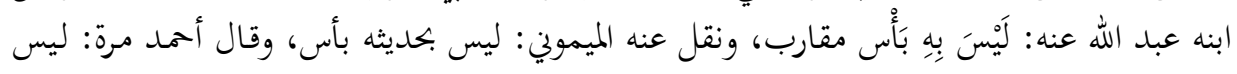

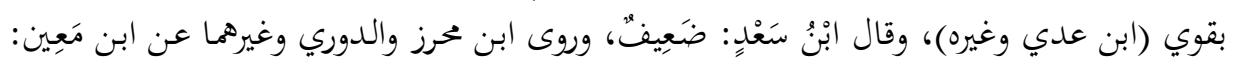

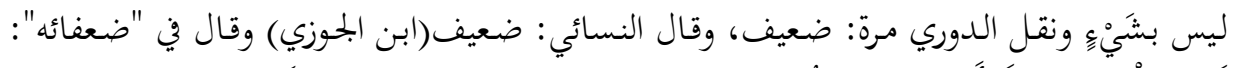

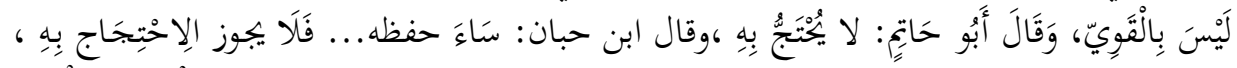

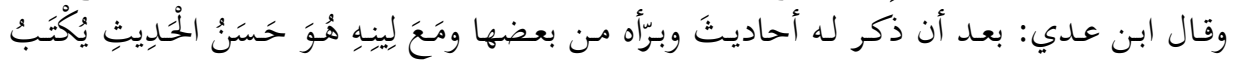

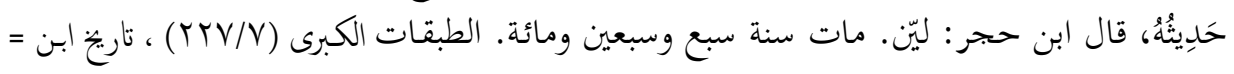



القول الحثيث في بيان مصطلح ( جائز الحديث) عند أئمة الحديث

** * قلت : خلاصة قول الأئمة "فيه لين؛ لغرائبه وأوهامه في الأسانيد ، لا يحتج به إذا انفرد، والله أعلم.

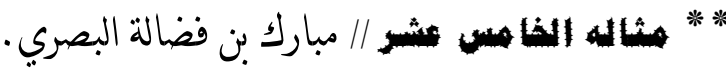

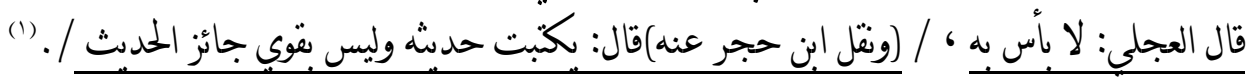

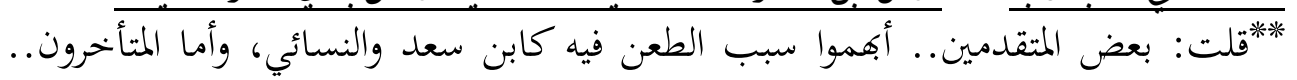

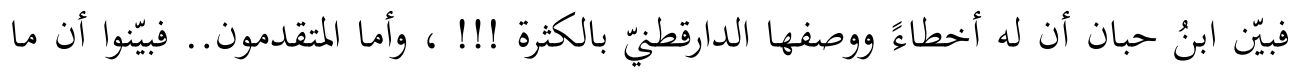

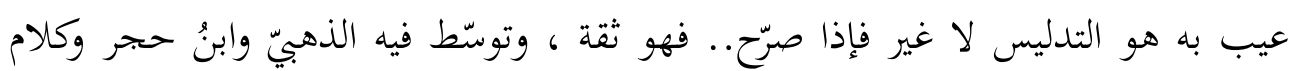
العجلي قريب منهما وسط، كما قال ابن المديني.

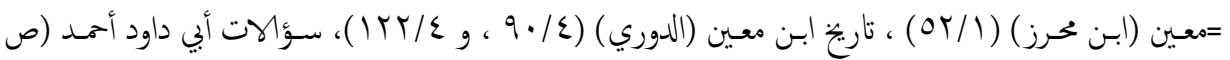

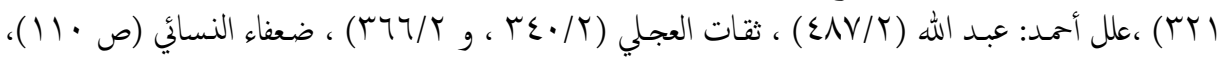

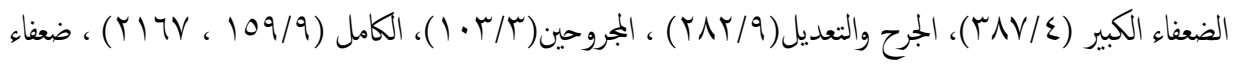

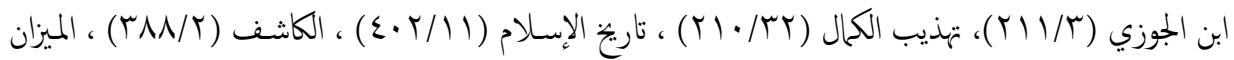

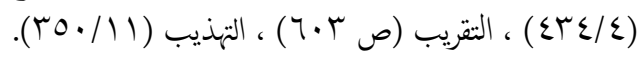

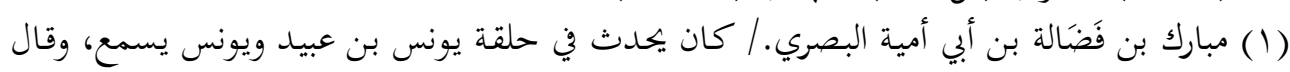

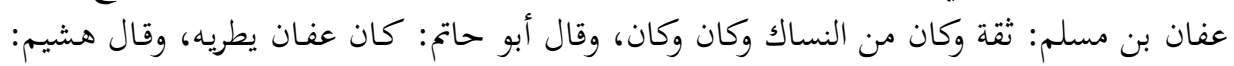

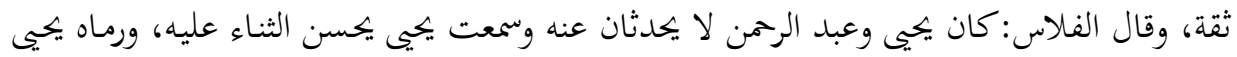

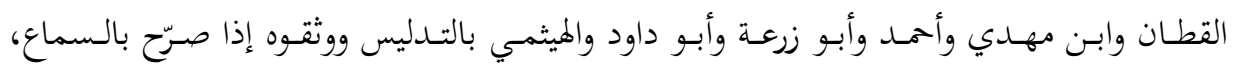

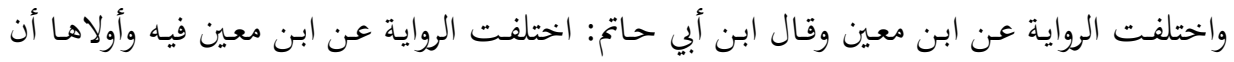

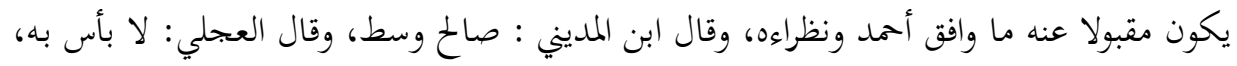

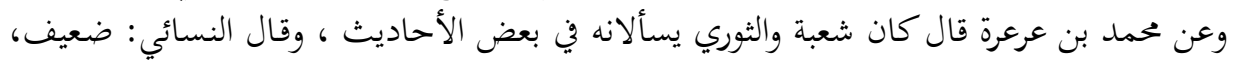

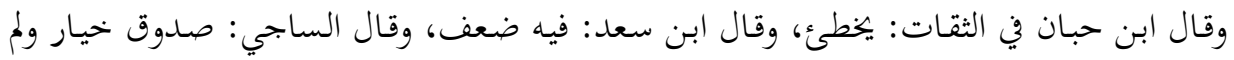

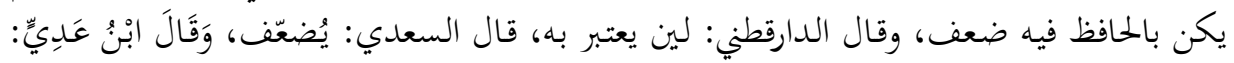

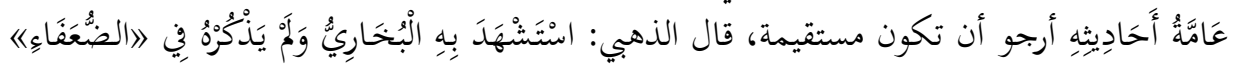

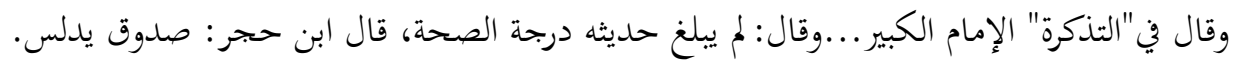

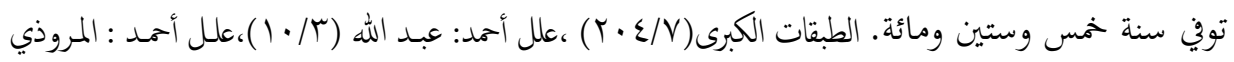

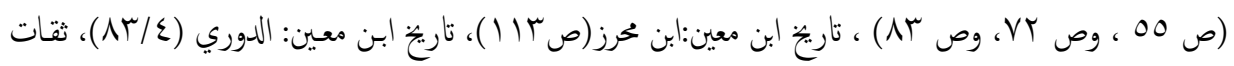

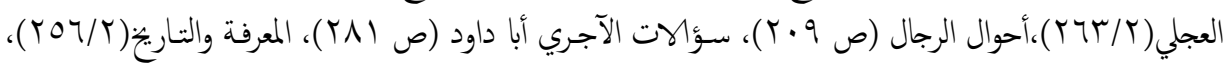

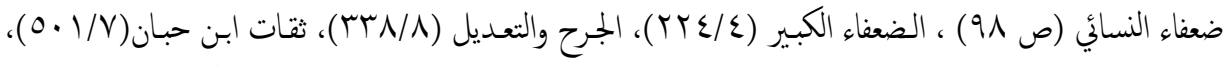

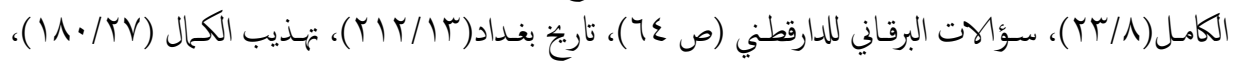

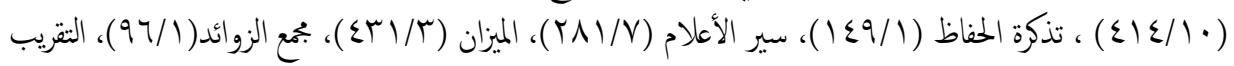

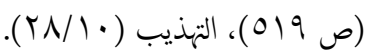




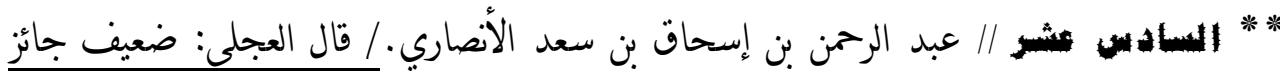

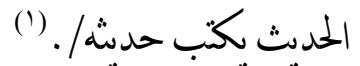

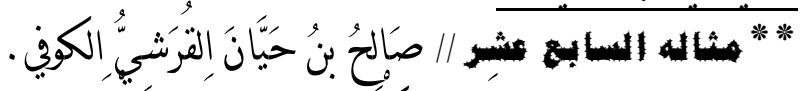

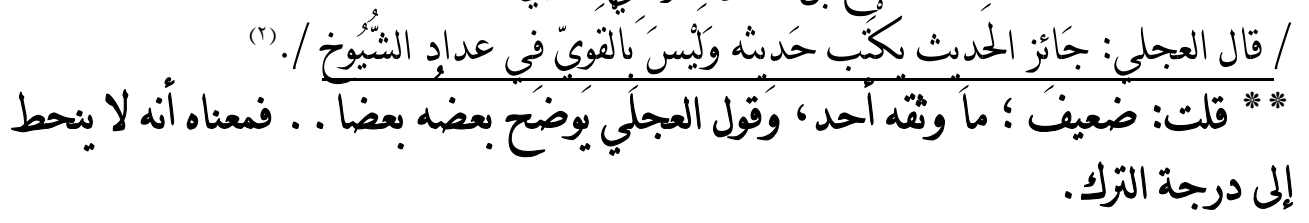

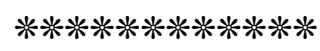

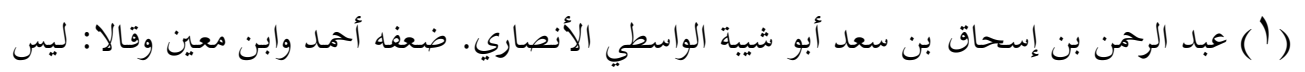

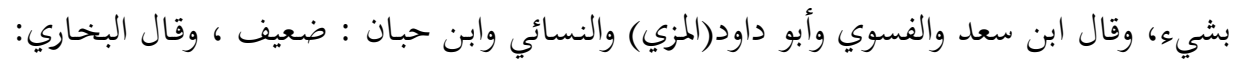

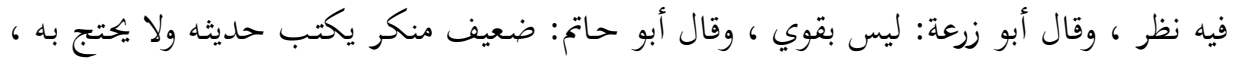

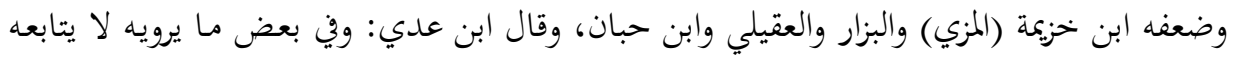

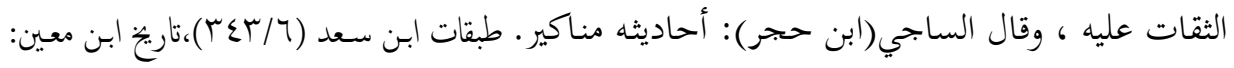

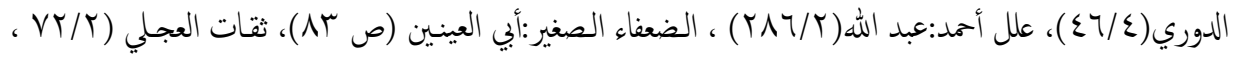

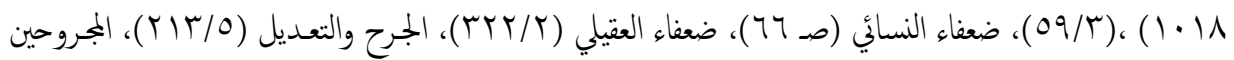

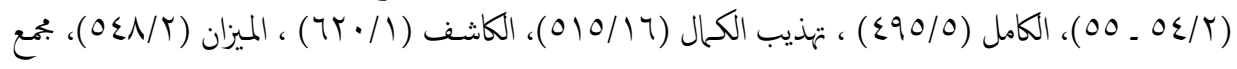

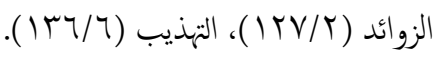

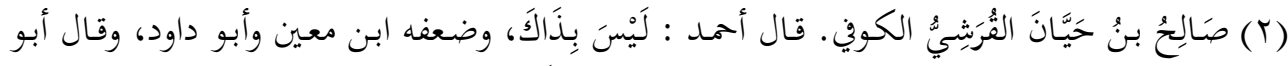

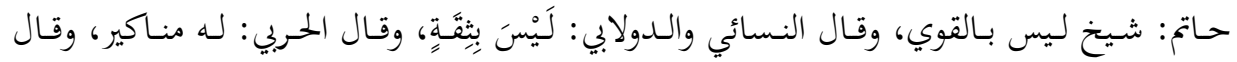

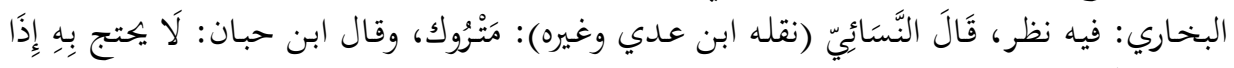

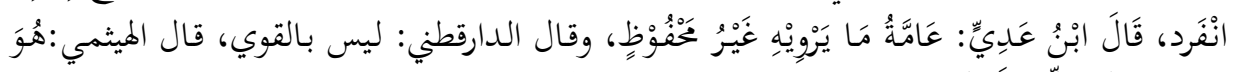

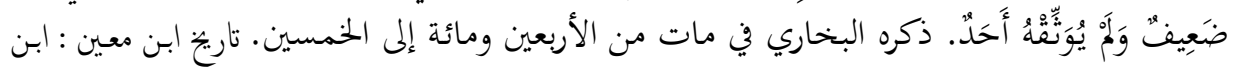

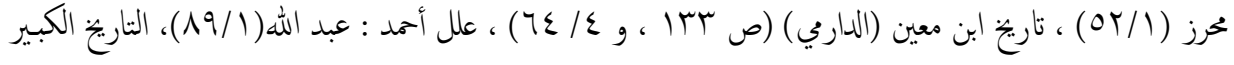

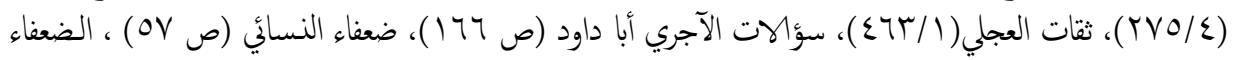

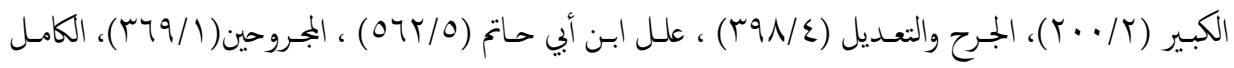

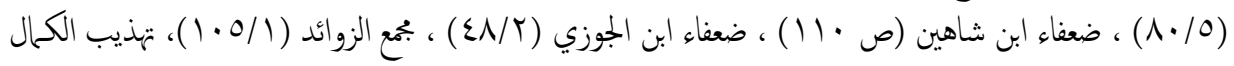

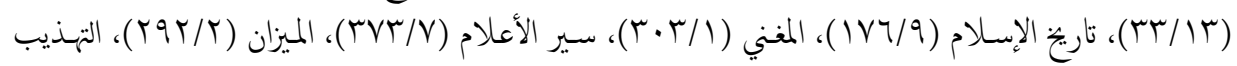

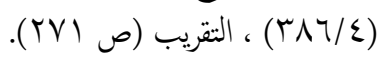


=

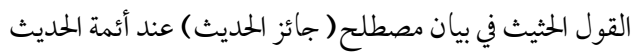

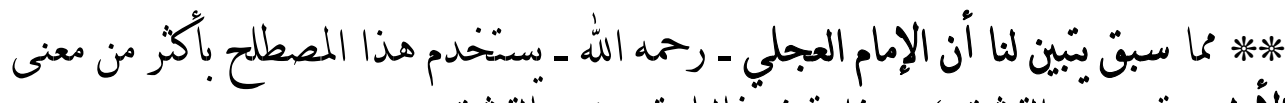

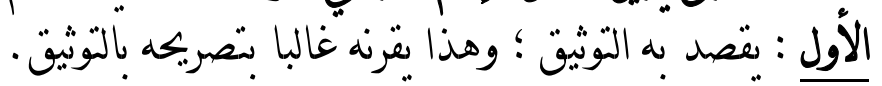

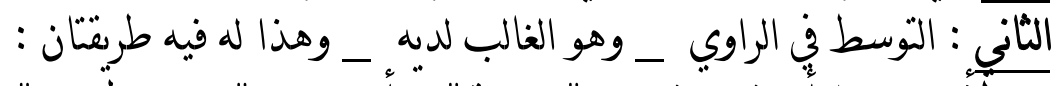

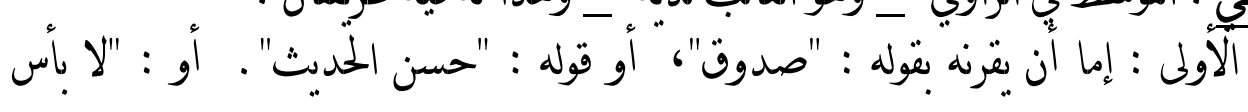

الثانية : وإما أن يطلق فيه مصطلح " جائز الحديث " دون أن بتبعه بكلام آخر.

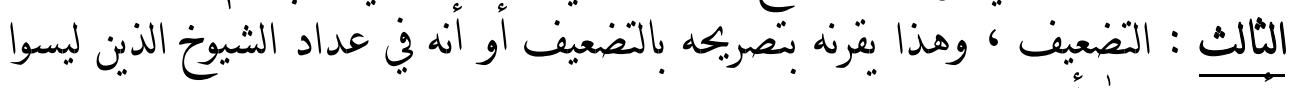
بأقوياء ، والله أعلم. 


\section{الناظر في منهج الإمام الذهبي ، رحمه الله ، في استخدام هذا المصطلح يجد له طرقا مختلفة في

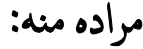

\section{Sg|l|l| \\ A}

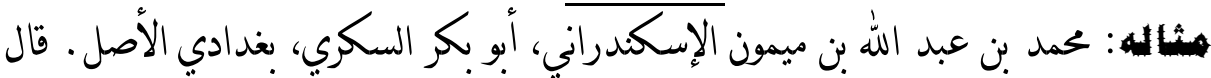

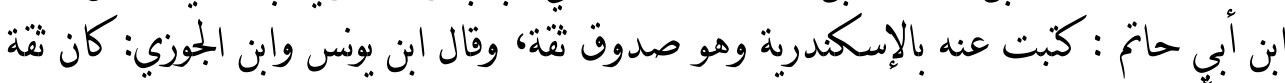

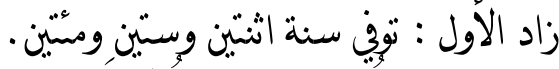

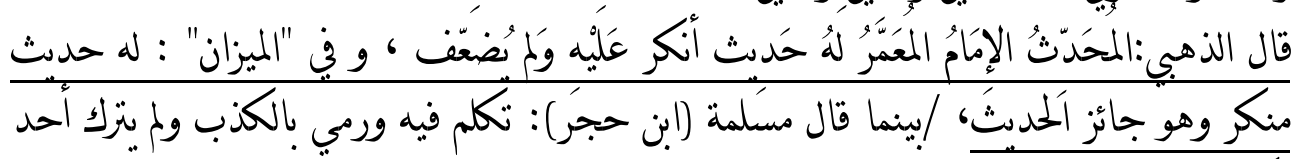

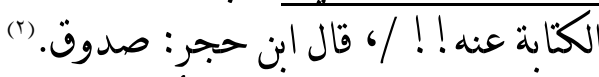

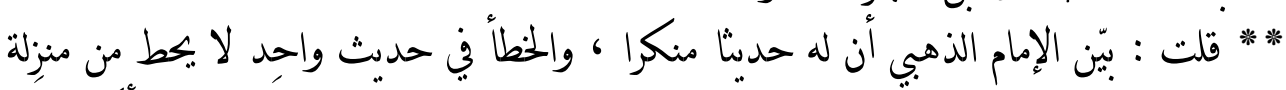

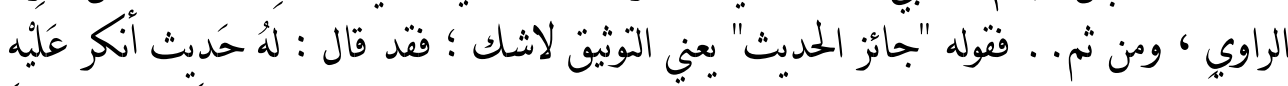

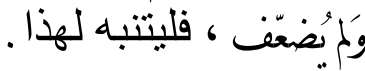

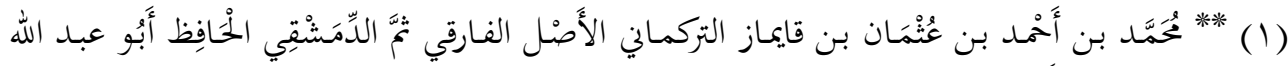

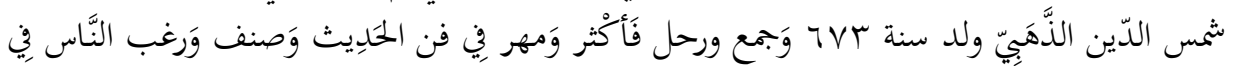

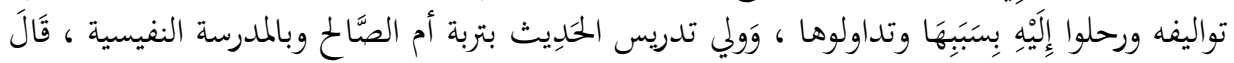

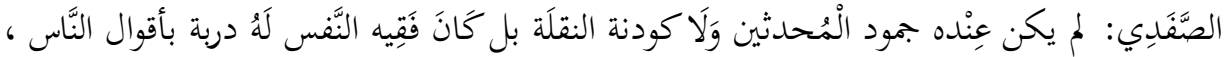

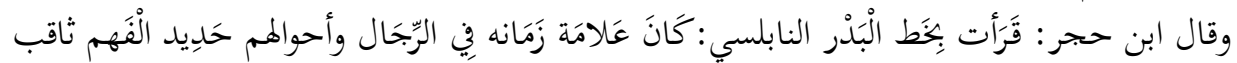

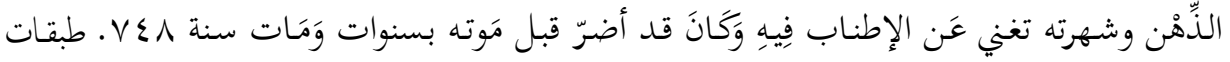

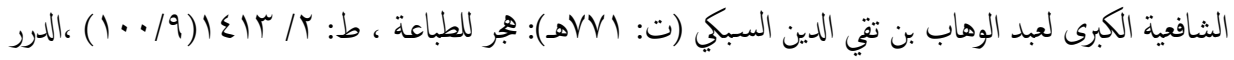

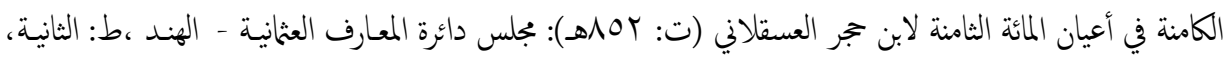
. (7T/0) 19VT/1\%9r

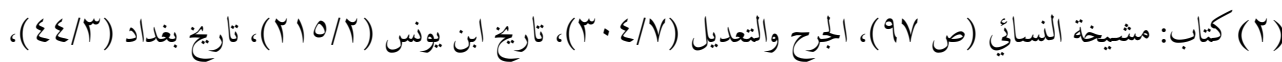

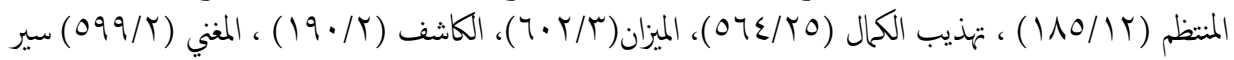

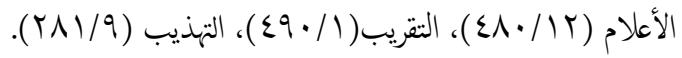




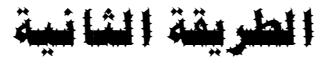

إطلاقه في المستورين الذين لم يجرحوا ، ومن روى عنه جماعة :

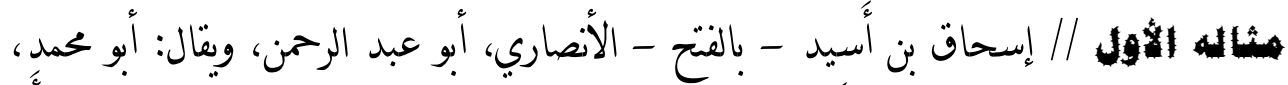

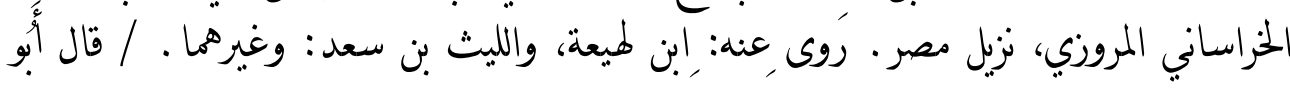

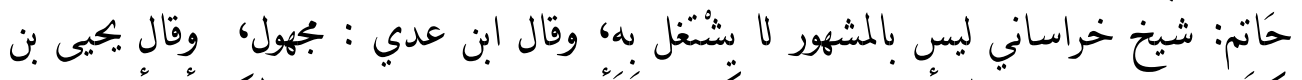

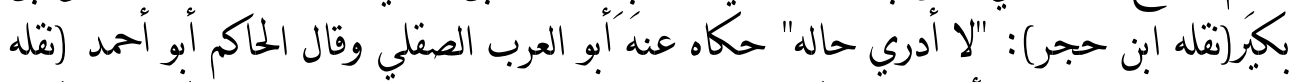

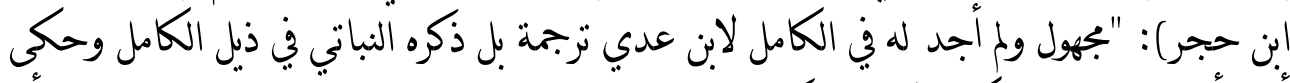

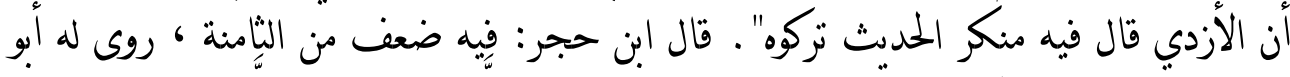

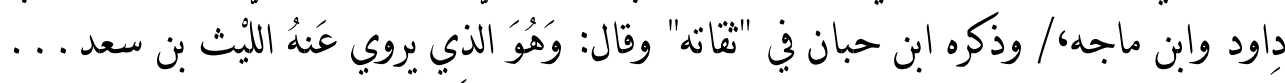

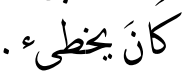

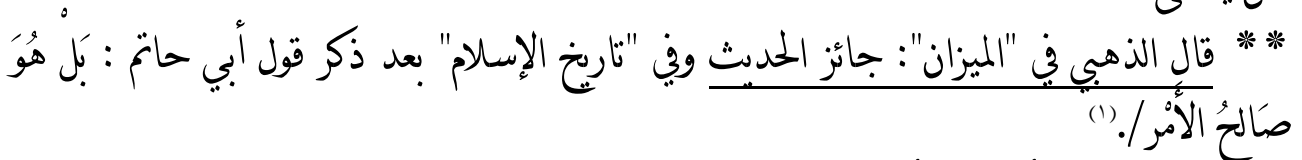

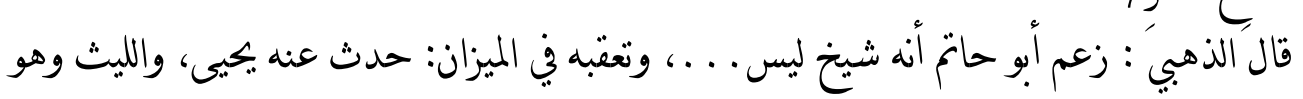

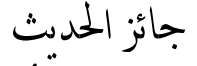

$$
\begin{aligned}
& \text { • قال "أبو حاتم: "شيخ ليس بالمشهور ولا شتغل به". }
\end{aligned}
$$

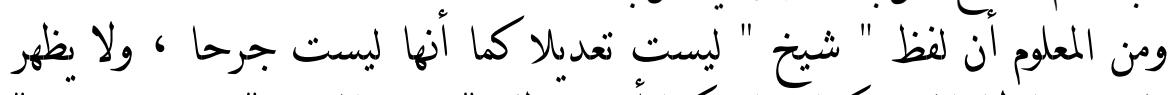

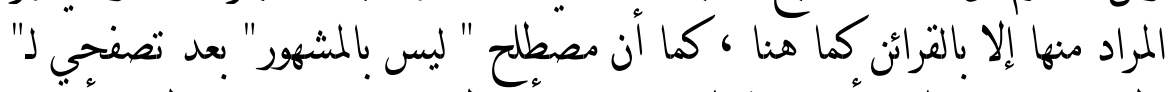

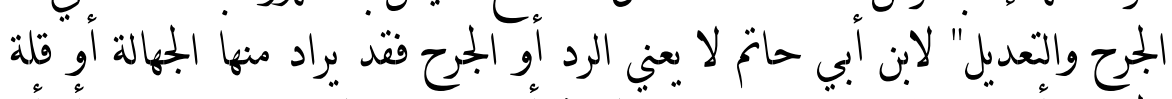

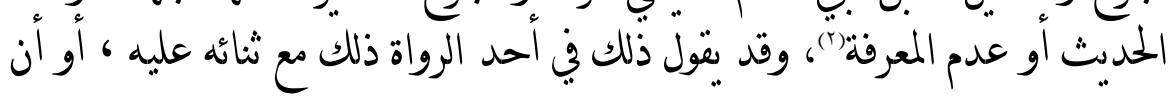

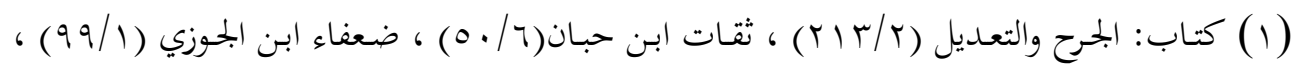

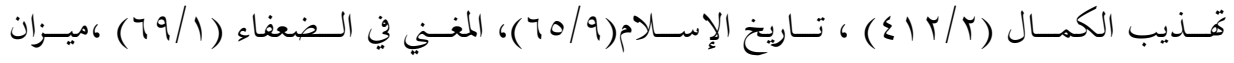

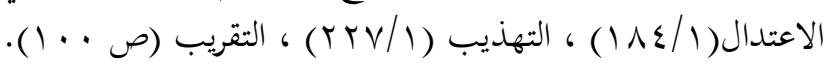

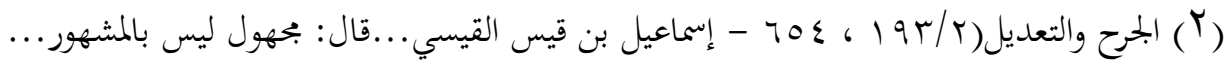

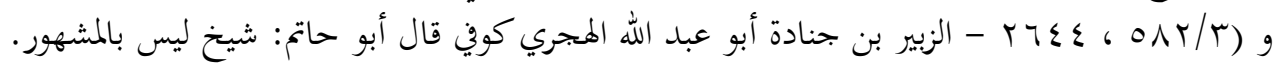

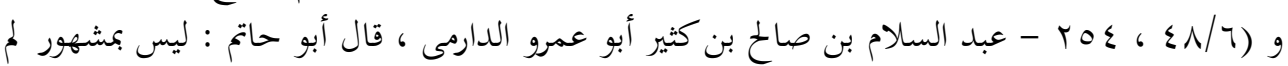

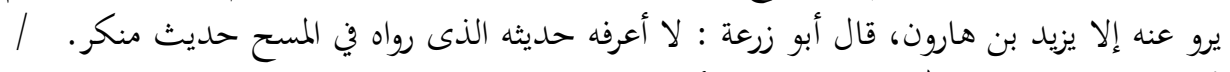

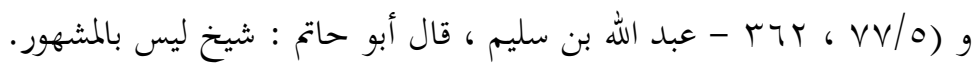

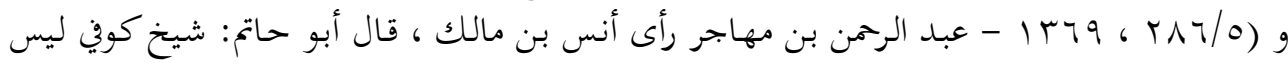




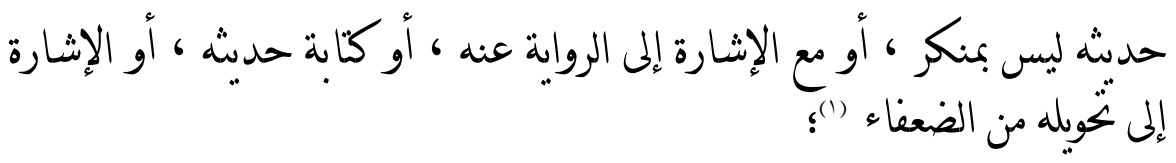

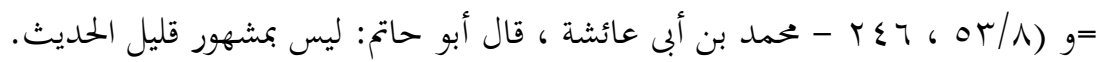

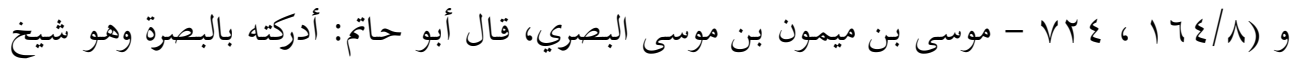

$$
\text { كبير ليس بالمشهور. }
$$

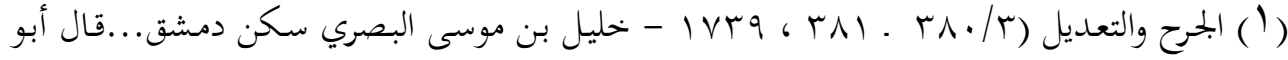

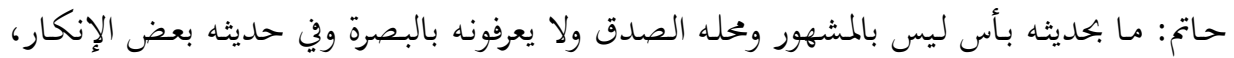

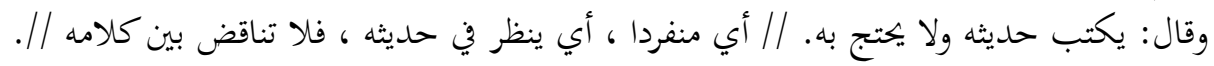

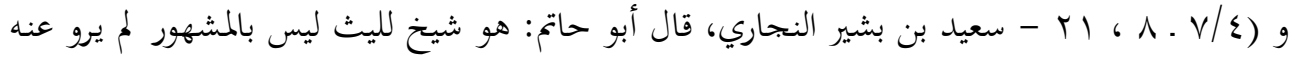

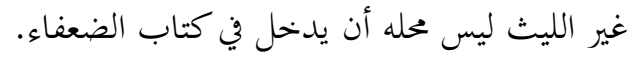

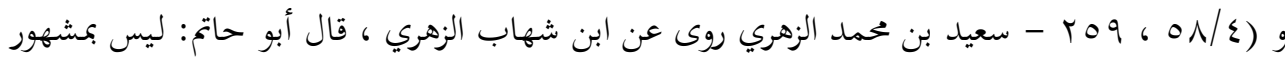
وحديثه مستقيم إنما روى حديثا واحدا.

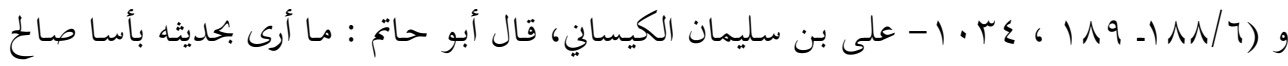
الحديث ليس بالمشهور.

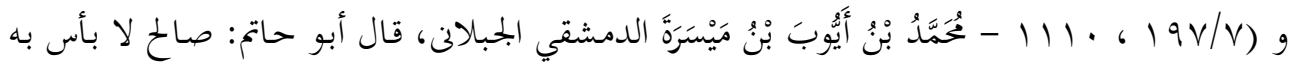
ليس بمشهور.

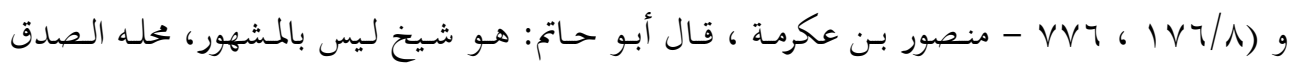
وأحاديثه مستقيمة.

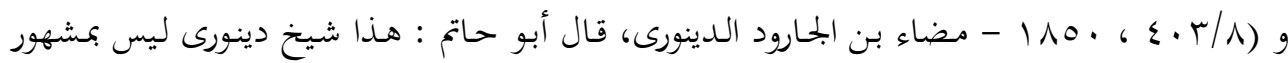
محله الصدق.

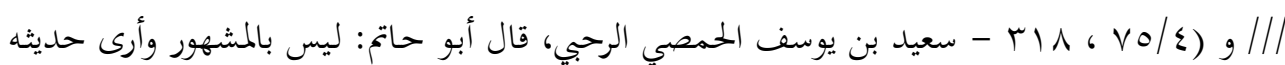
ليس بالمنكر.

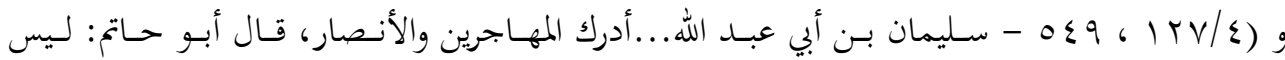
بالمشهور، فيعتبر بحديثه. و (1/ (11/ ، ع .0 - عبد الله بن عمر بن القاسم ، قال أبو حاتم: يُروى عنه ليس بالمشهور.

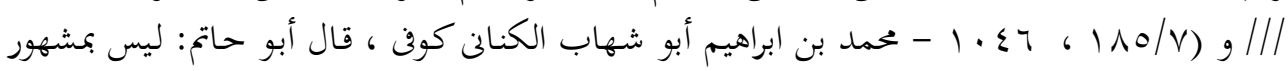
يكتب حديثه.

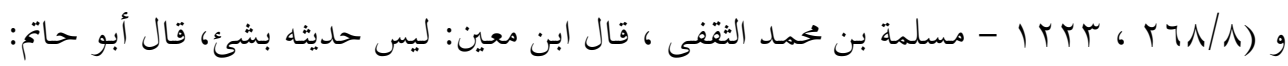

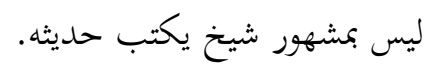

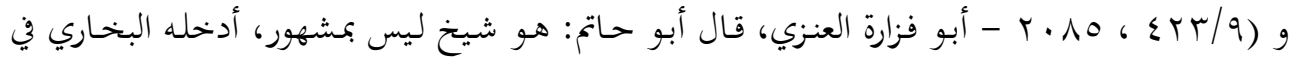
الضعفاء ويحول من هناك. 


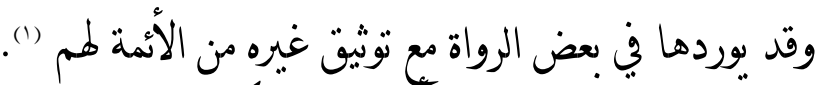

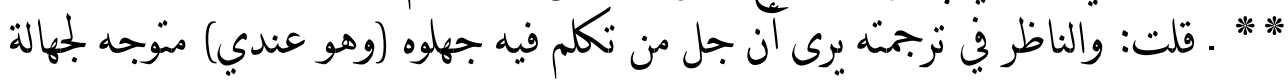

أما الضبط .. فلا شك أن أبا حاتم حاد النفس في الجرح ؛ فصدر كلامه متوجه الحال لا العبن. الح.

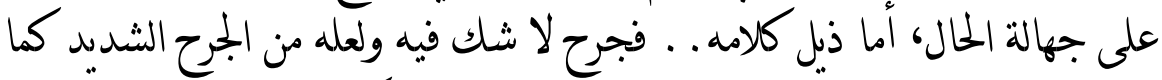

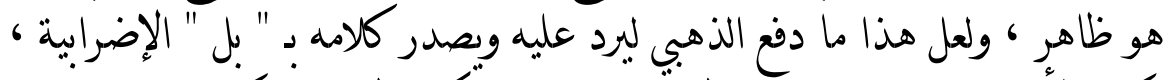

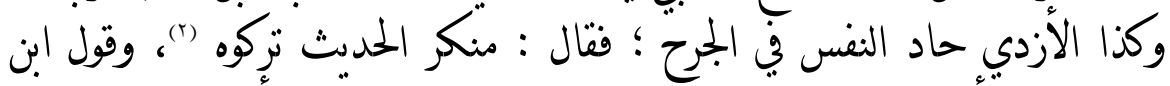

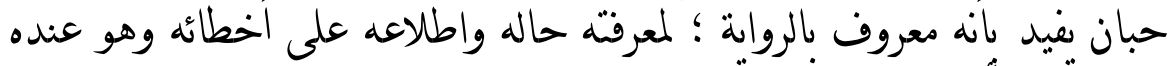

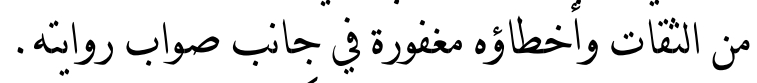

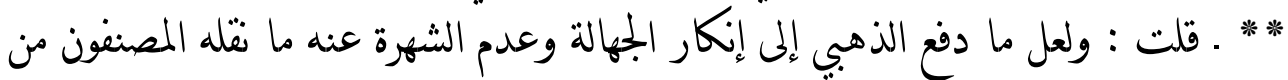

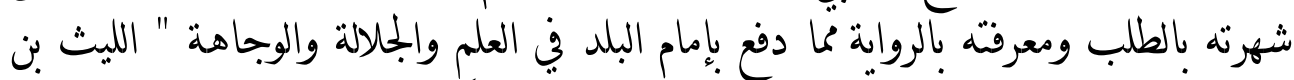

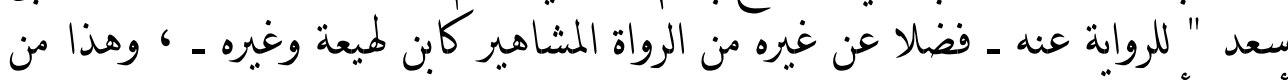

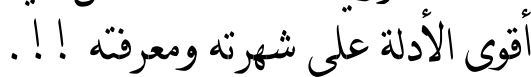

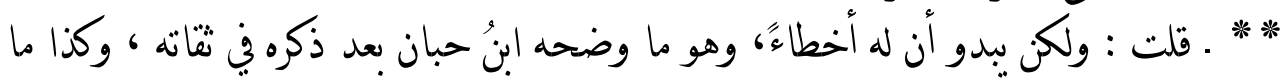

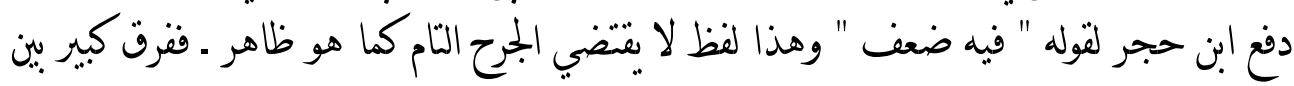

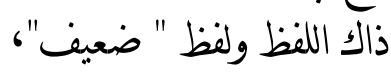

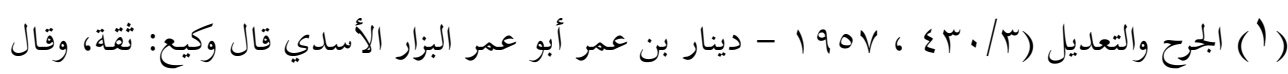
أبو حاتم: ليس بالمشهور.

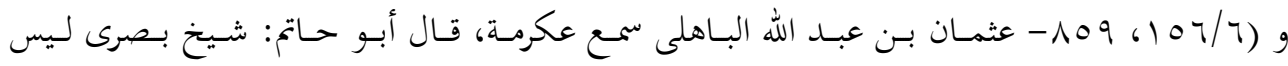
بالمشهور، وقال ابن معين: ثقة.

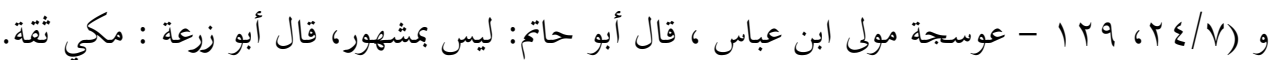

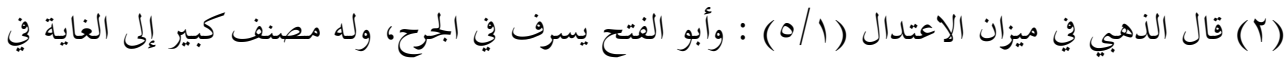

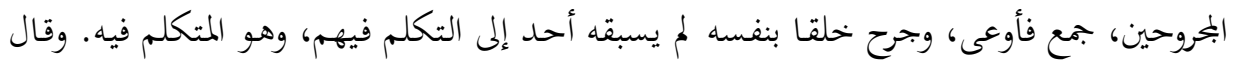

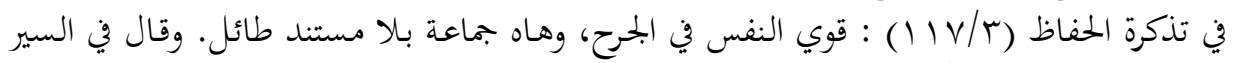

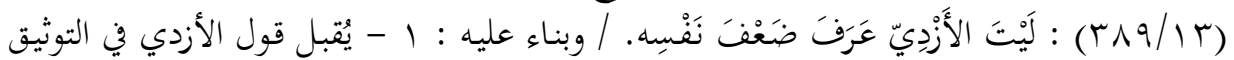

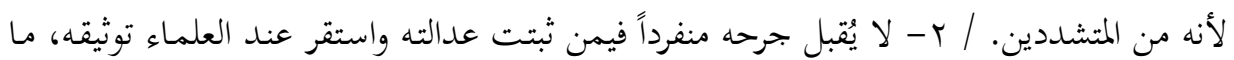

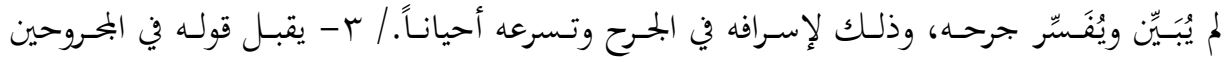

المشهورين بالضعف من غير بيان سبب. 

القول الحثيث في بيان مصطلح ( جائز الحديث) عند أئمة الحديث

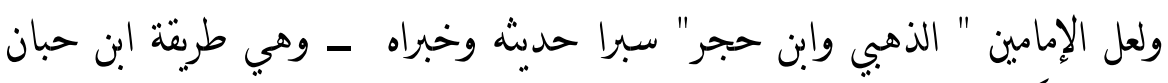

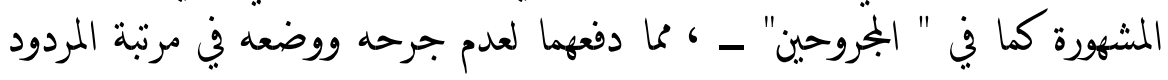

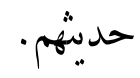

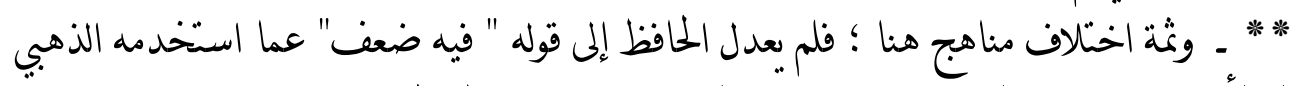

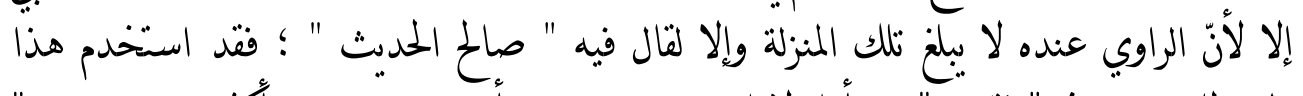

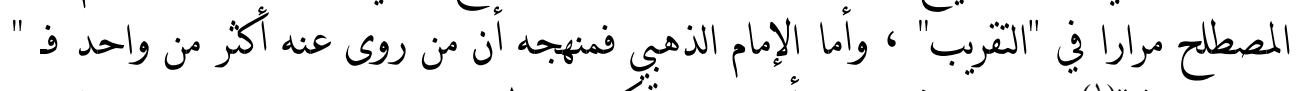

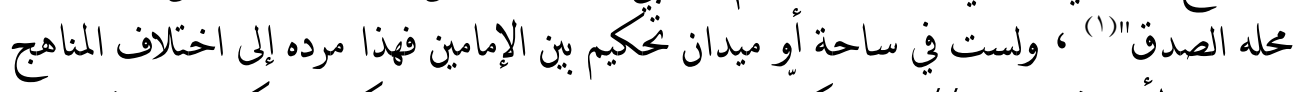

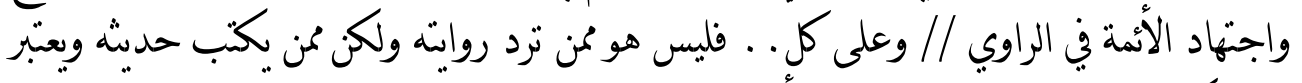

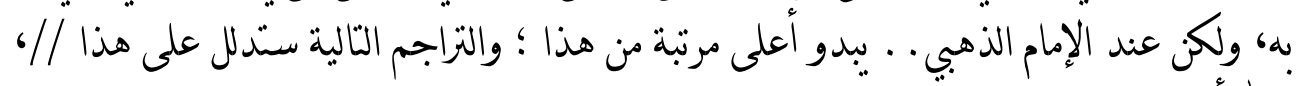

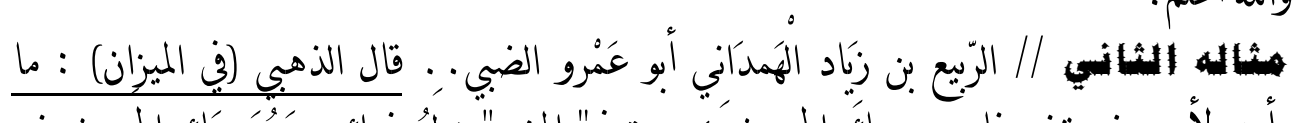

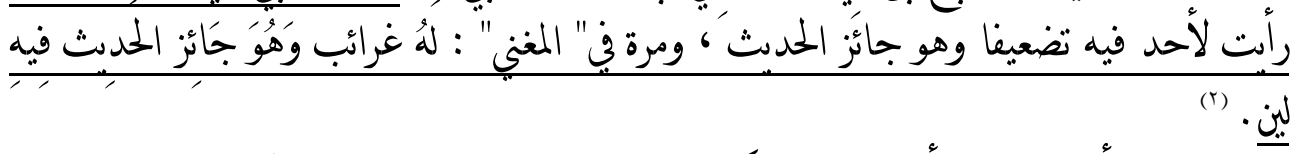

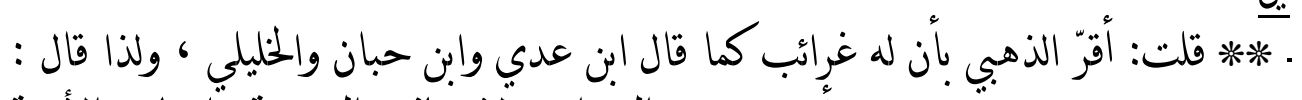

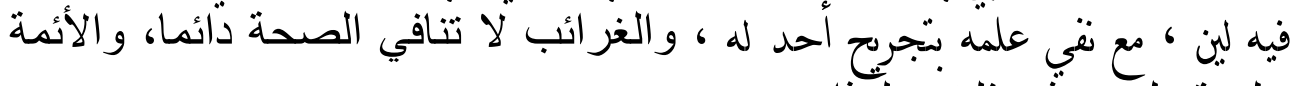
على قبول حديثّه، فليتنبه لهذّا.

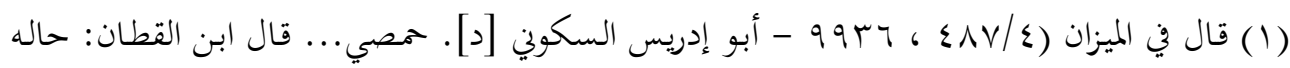

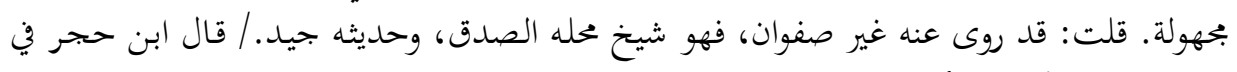

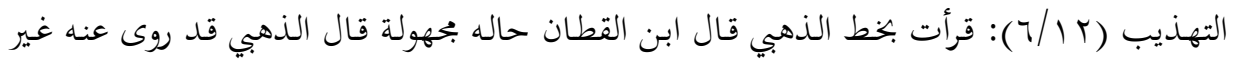

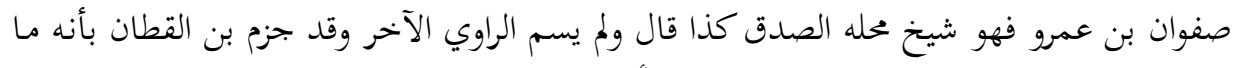

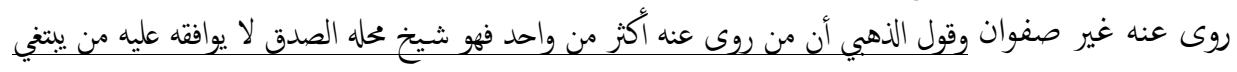

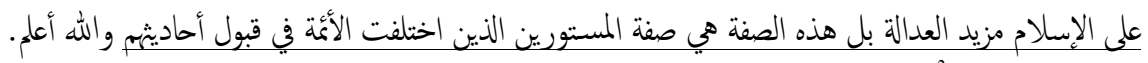

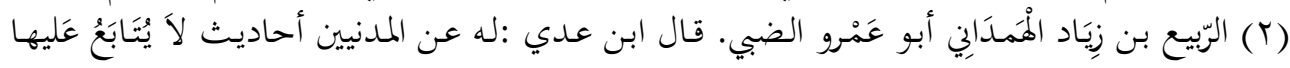

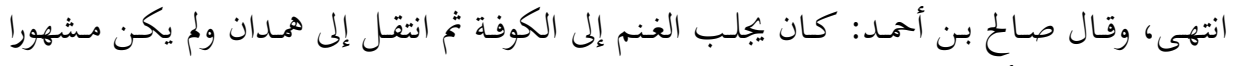

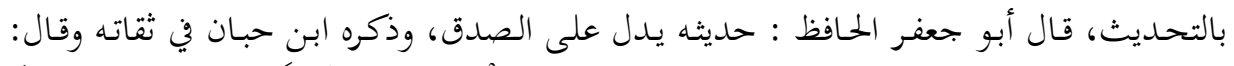

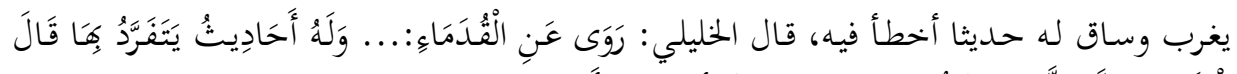

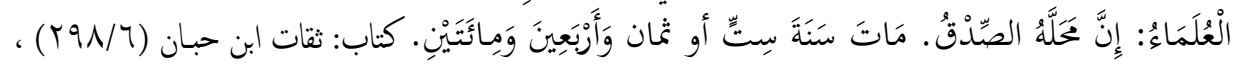

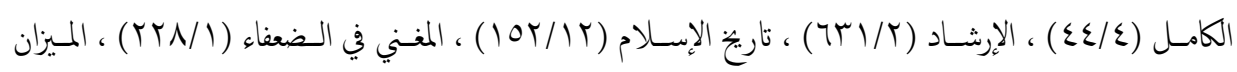

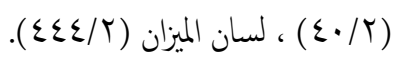



القول الحثيث في بيان مصطلح ( جائز الحديث) عند أئمة الحديث

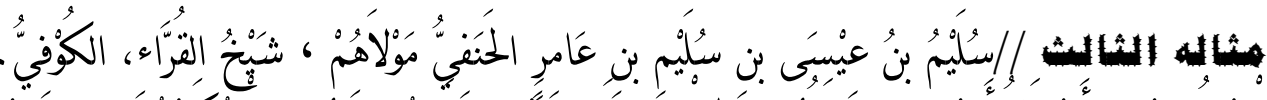

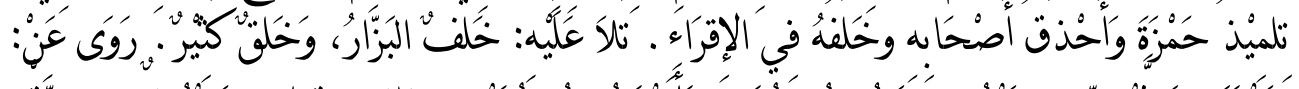

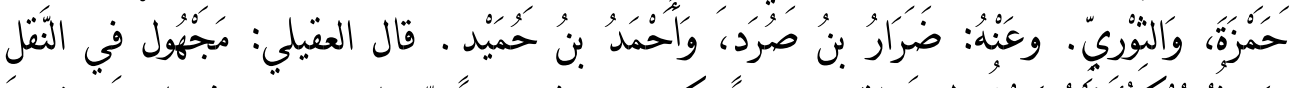

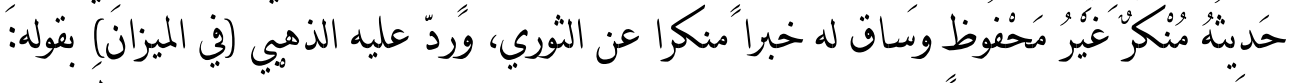

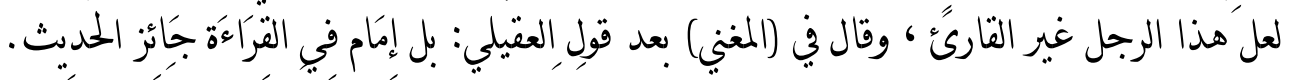

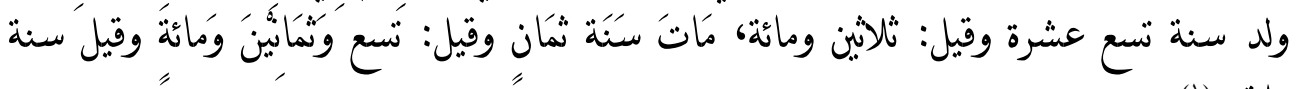
مائنبن. (1)

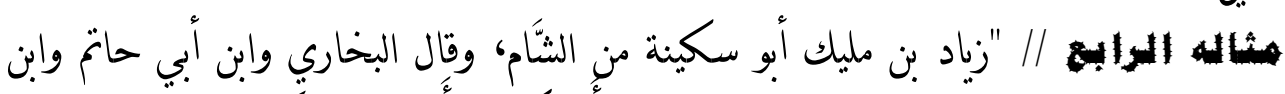

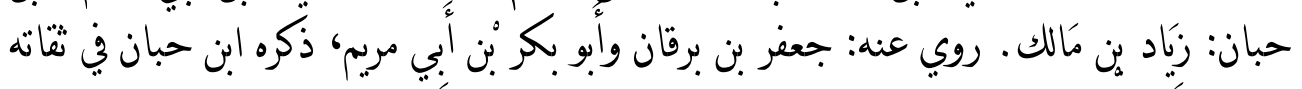

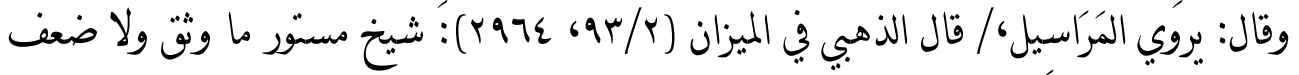

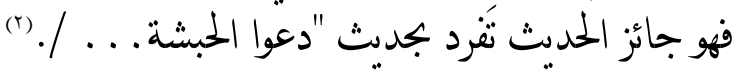

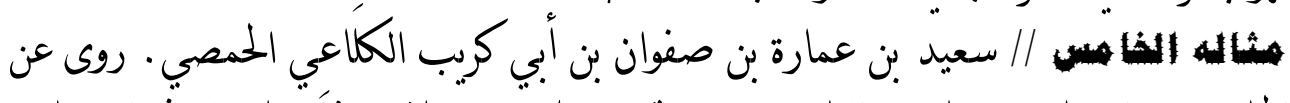

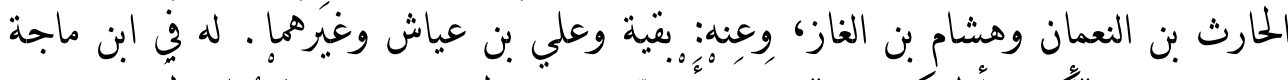

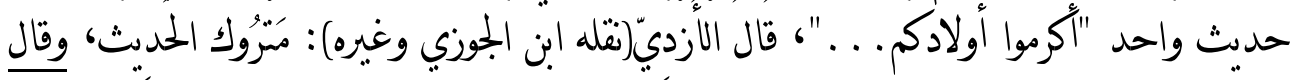

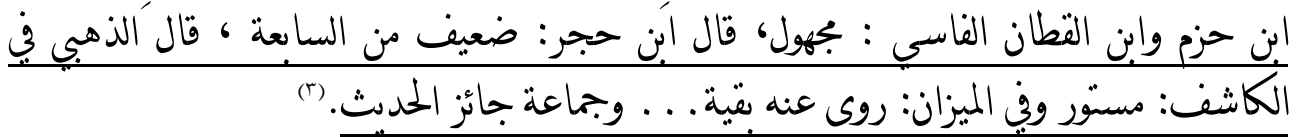

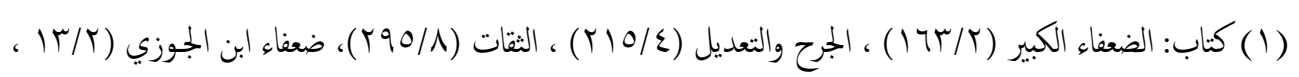

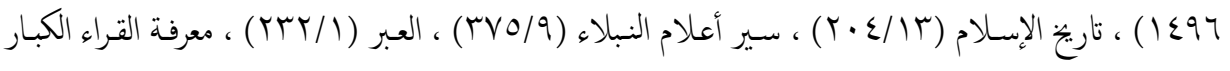

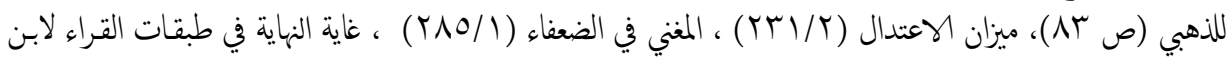

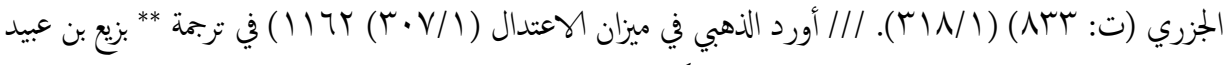

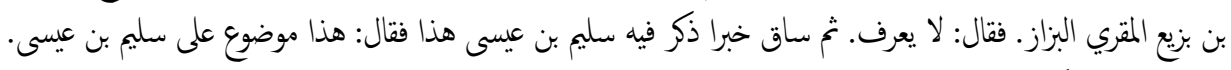

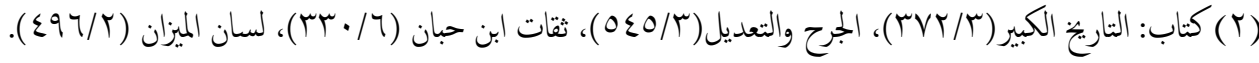

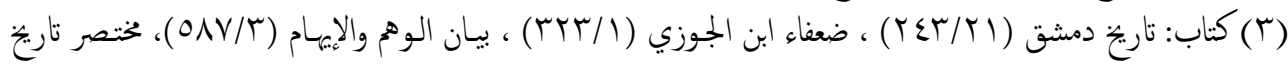

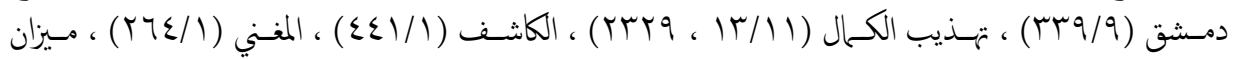

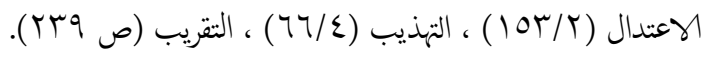




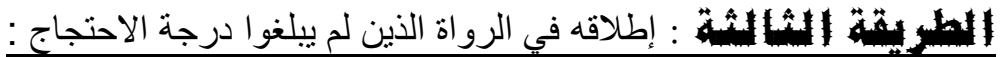

\author{
وله في تلك الطريقة منهجان :
}

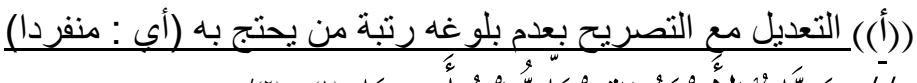

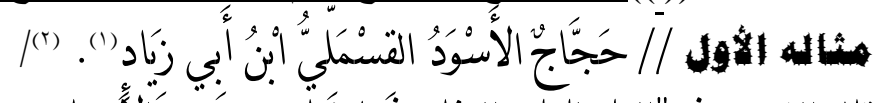

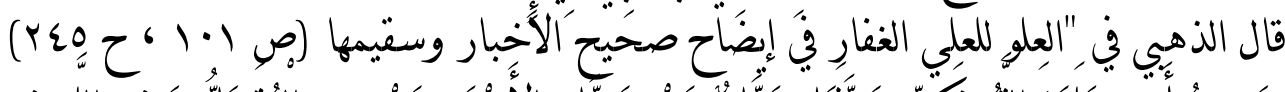

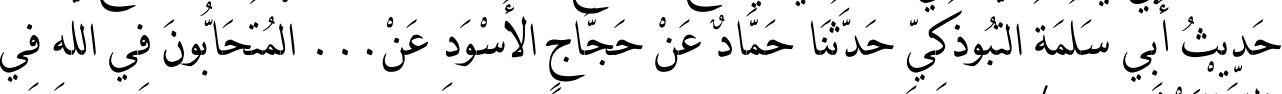

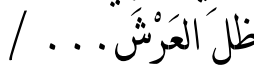

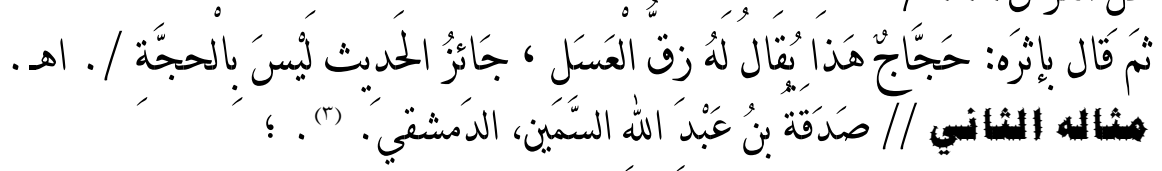

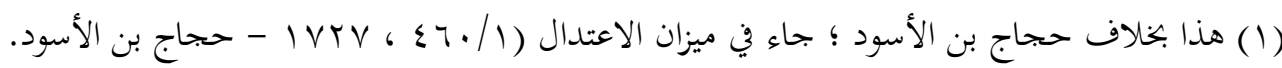

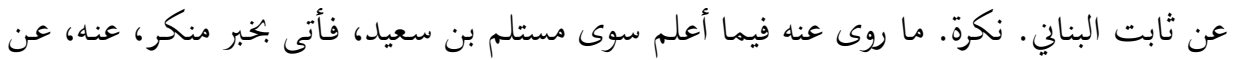

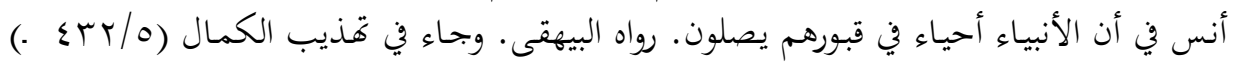

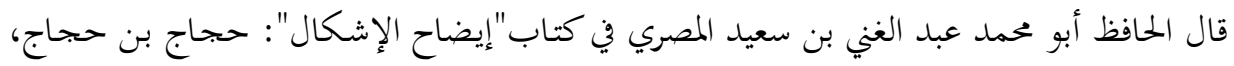

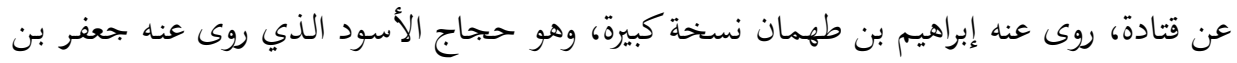

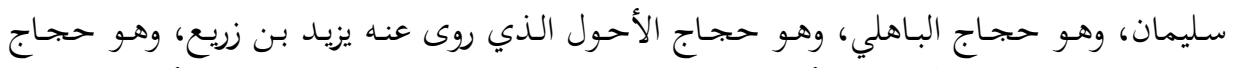

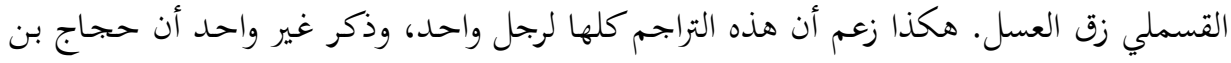

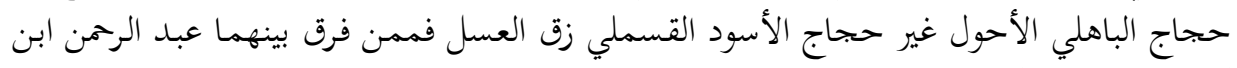

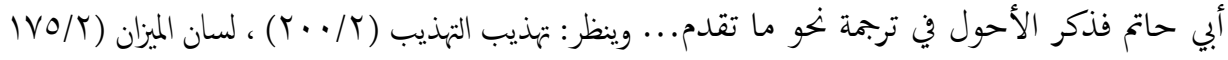

. (VAV ، IVT.

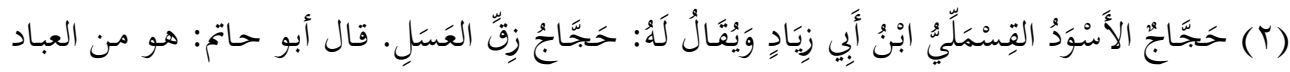

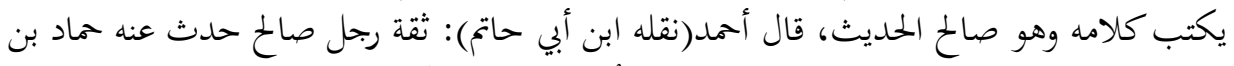

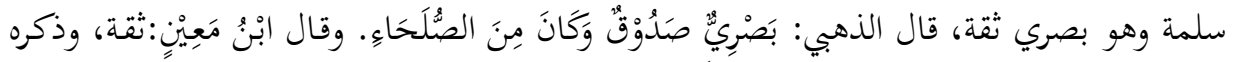

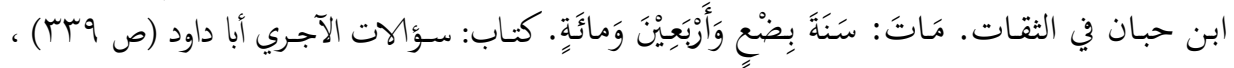

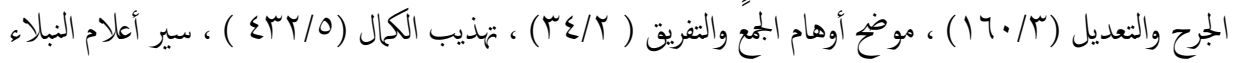

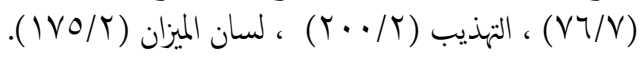

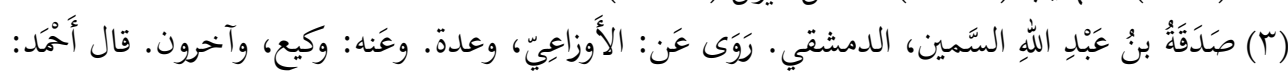

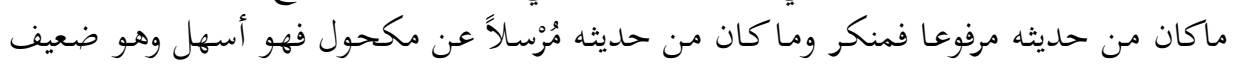

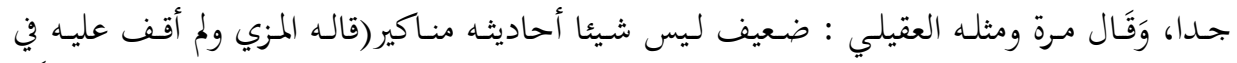

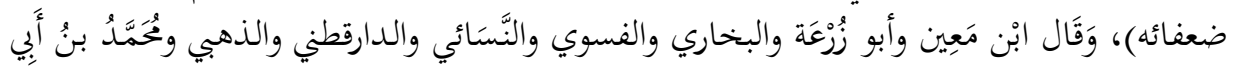

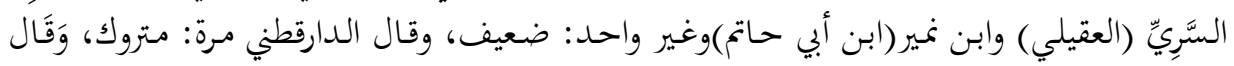

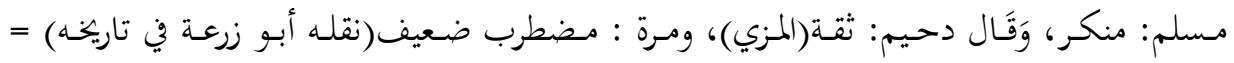




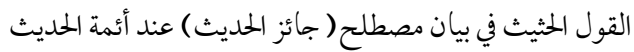

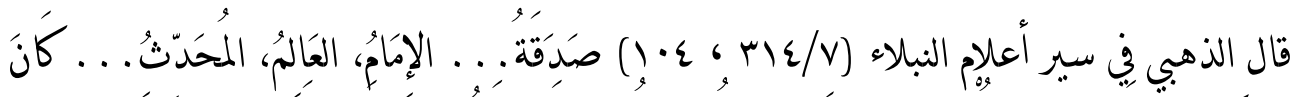

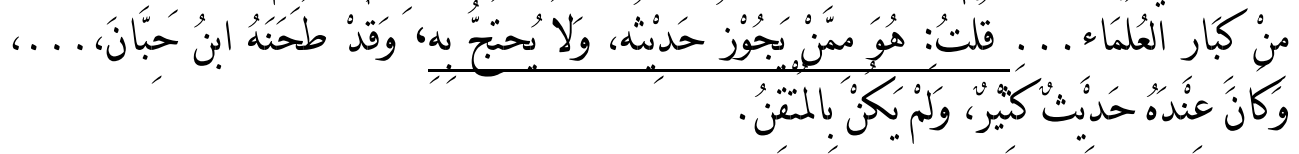

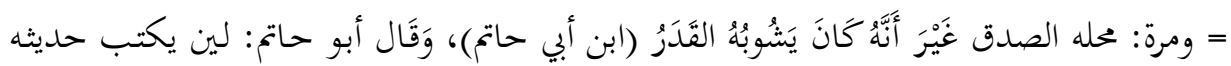

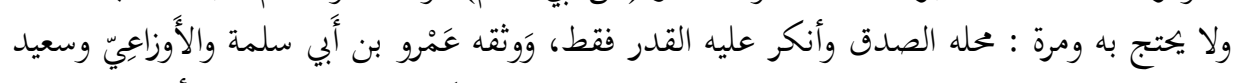

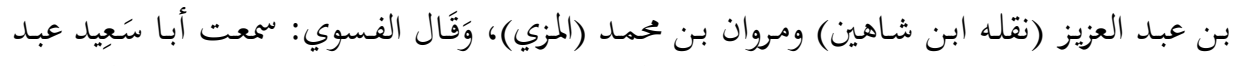

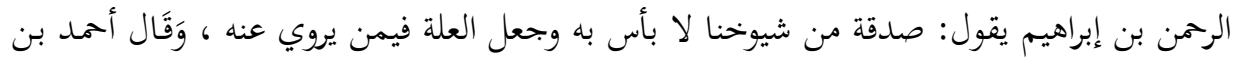

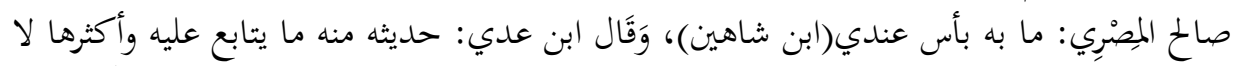

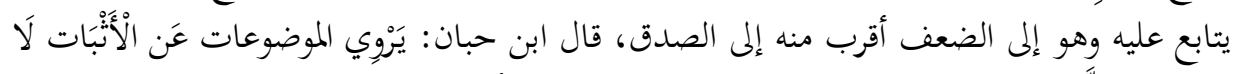

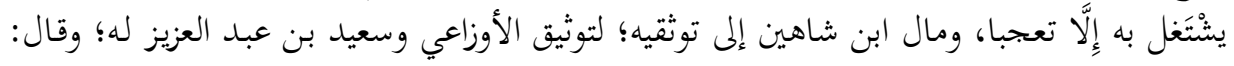

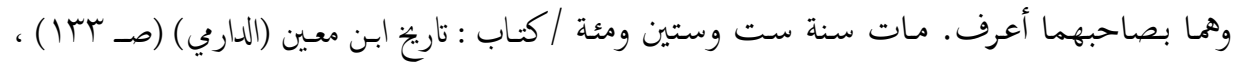

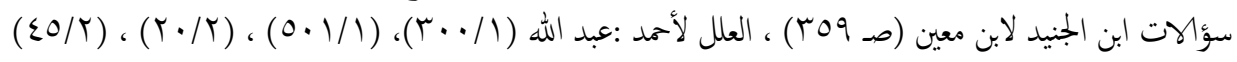

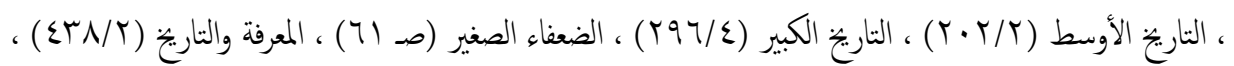

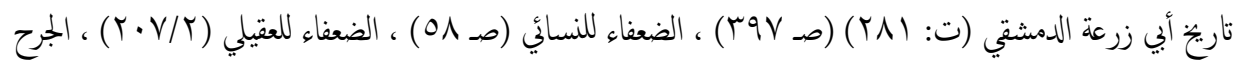

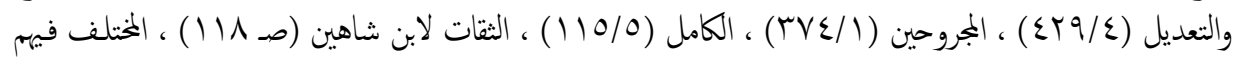

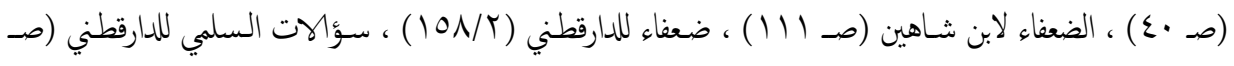

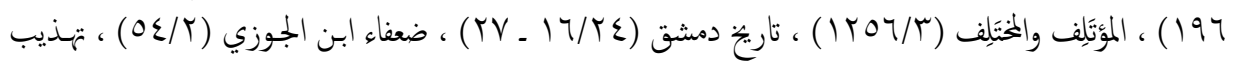

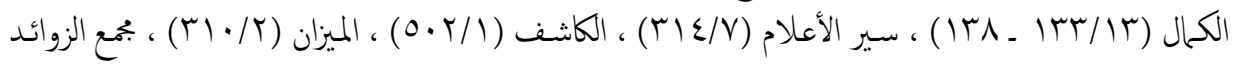

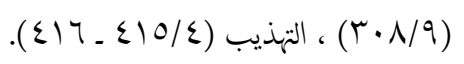




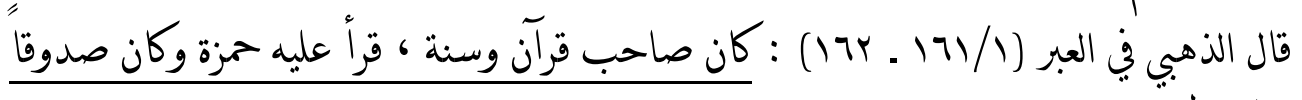
جائز الحدنث.

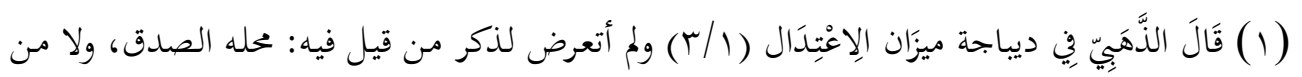

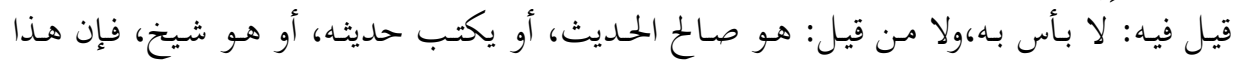

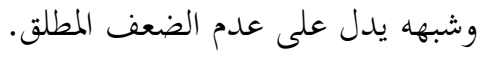

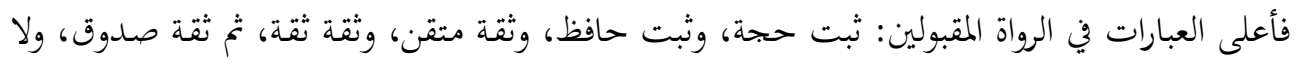

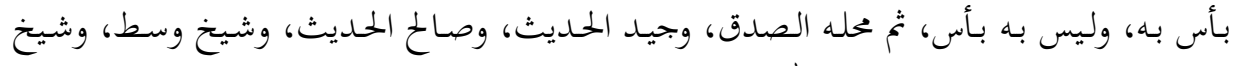

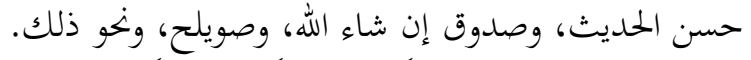

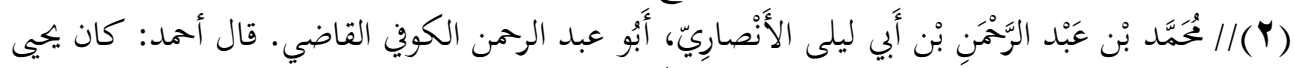

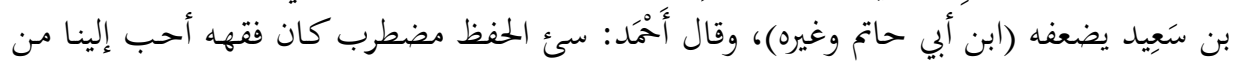

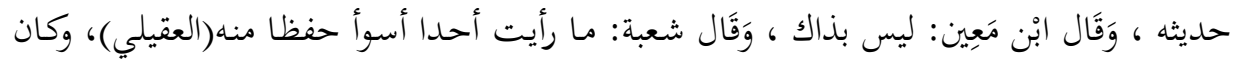

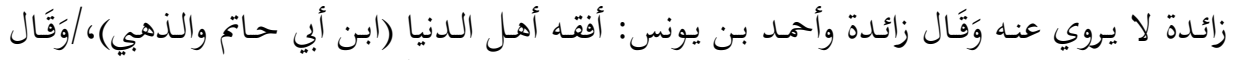

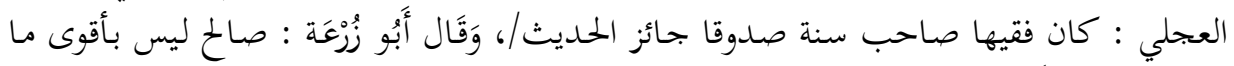

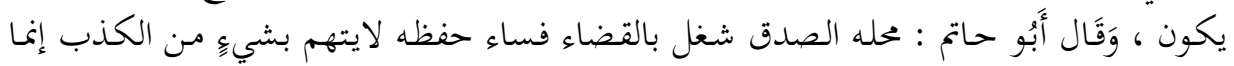

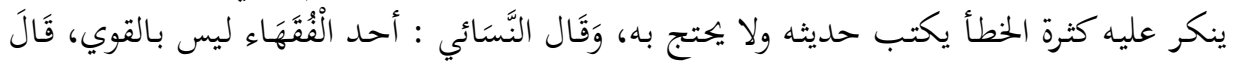

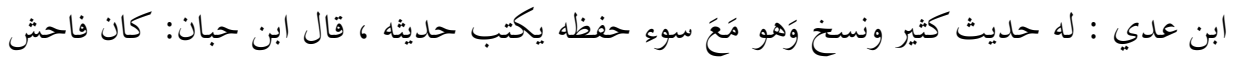

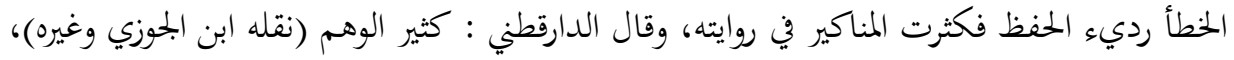

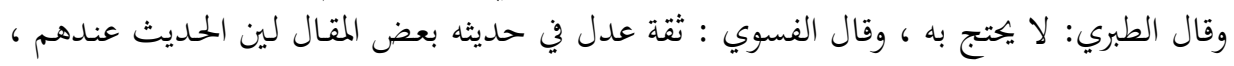

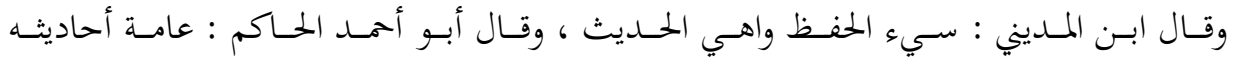

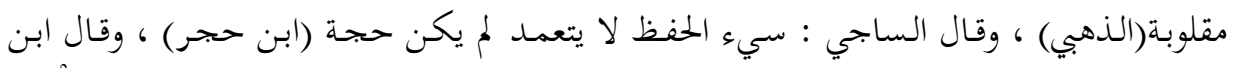

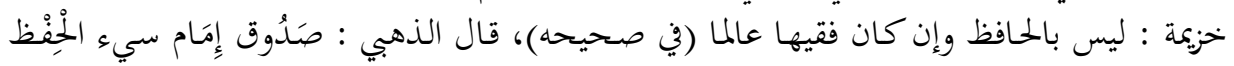

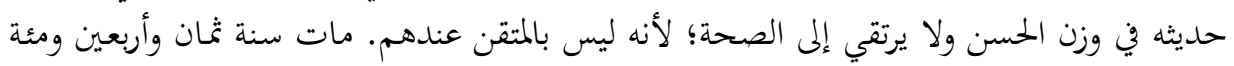

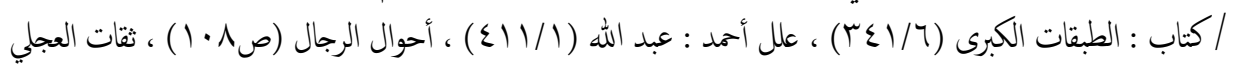

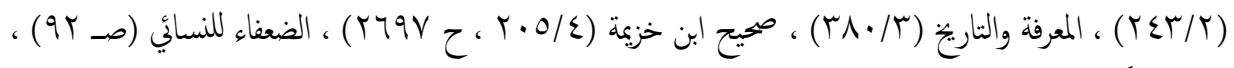

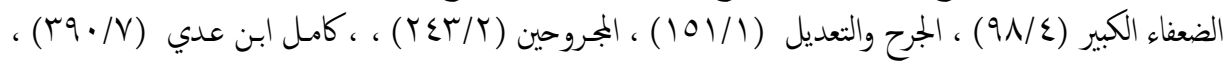

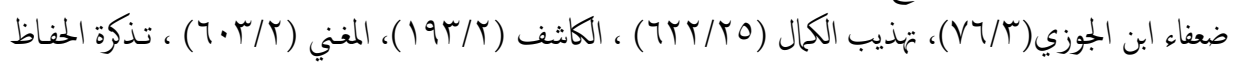

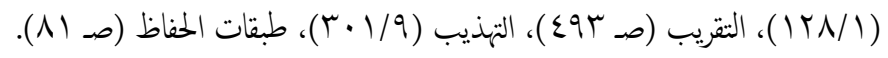




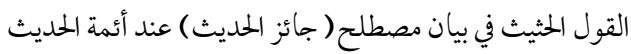

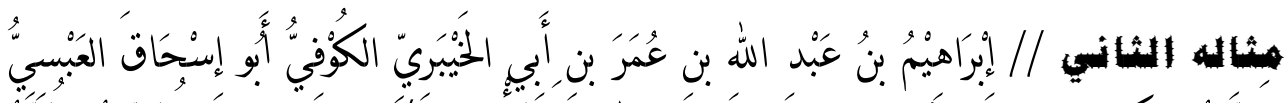

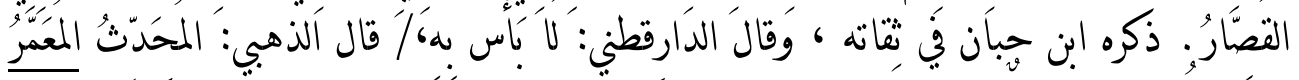

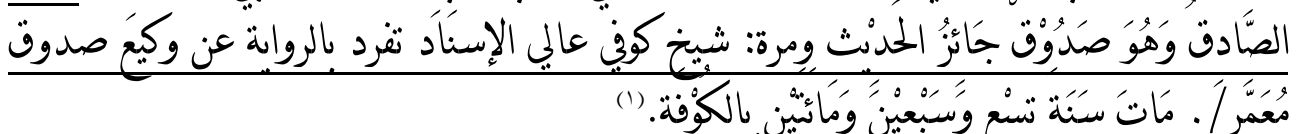

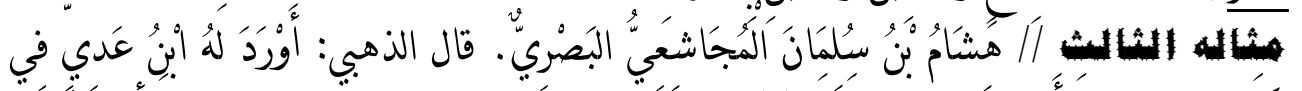

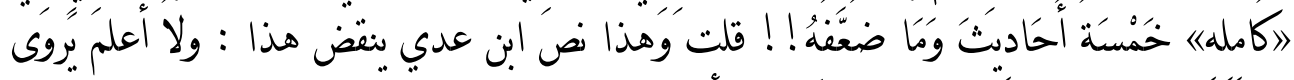

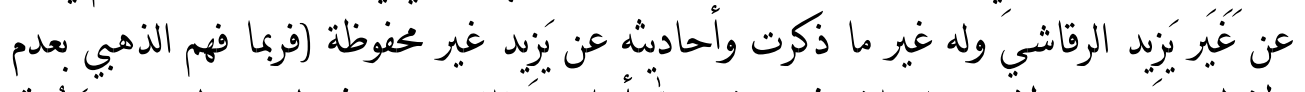

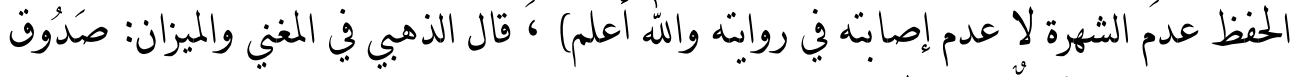

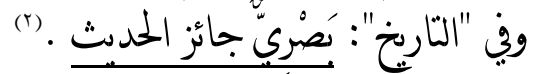

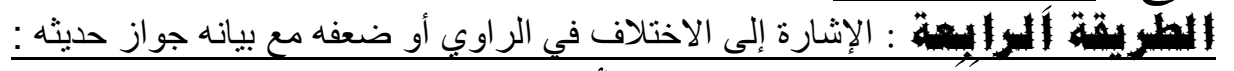

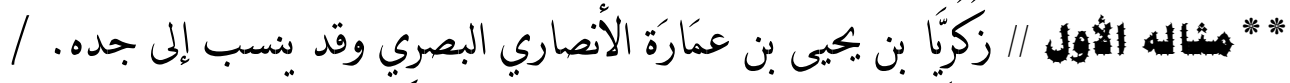

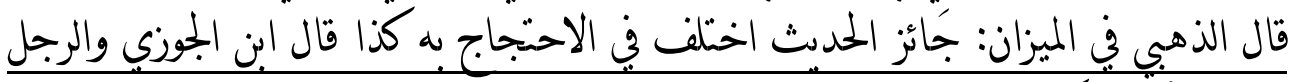

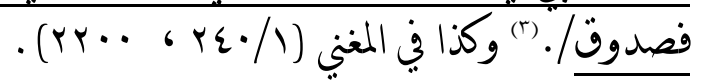

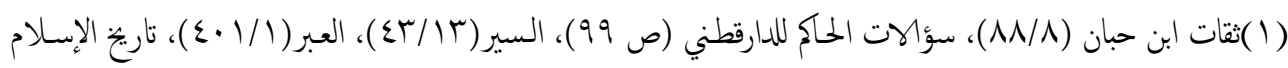

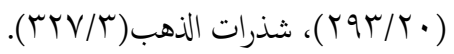

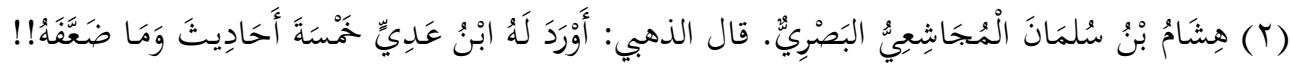

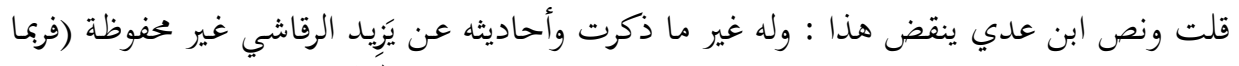

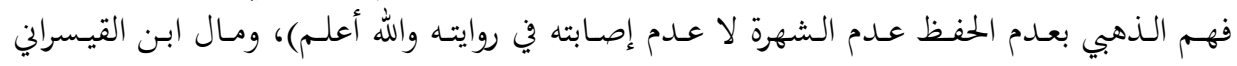

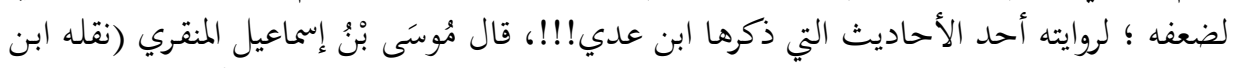

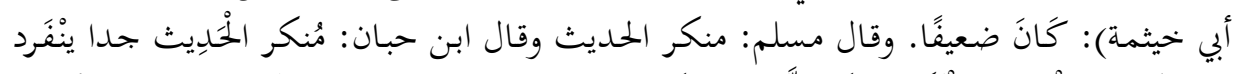

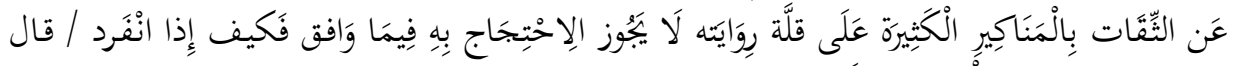

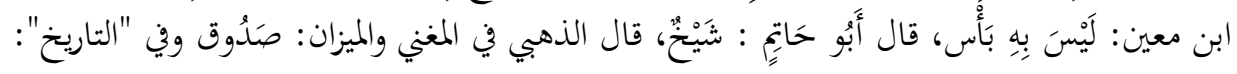

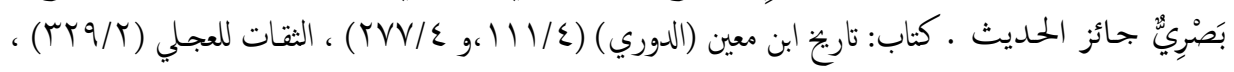

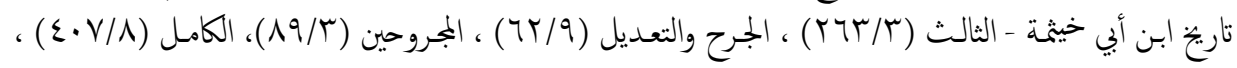

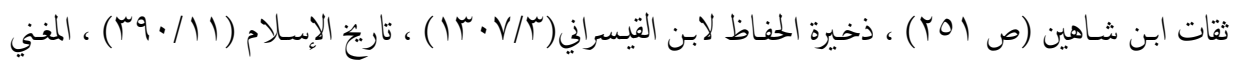

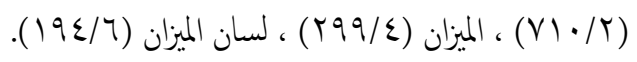

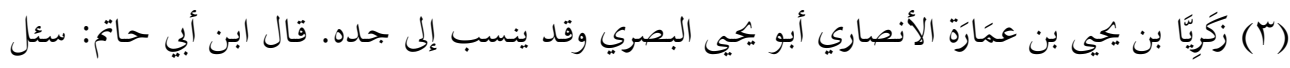

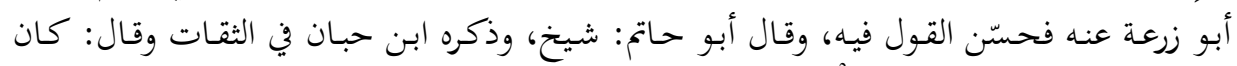

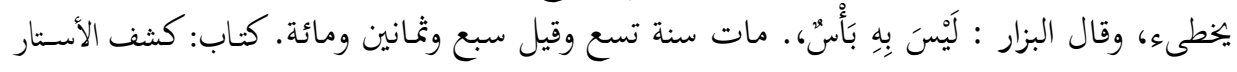

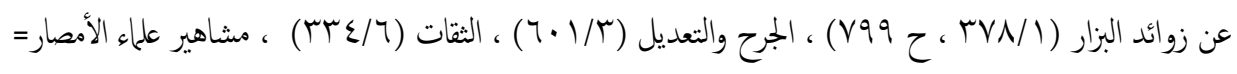




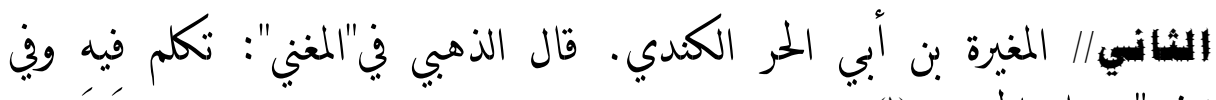

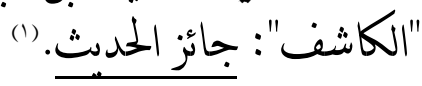

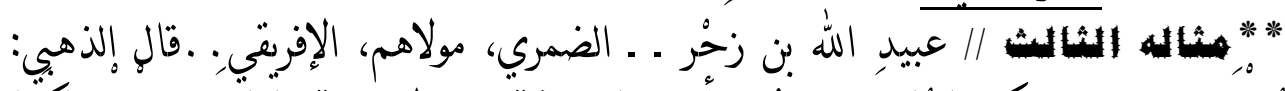

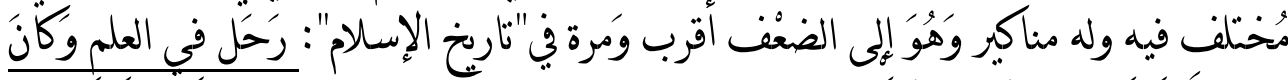

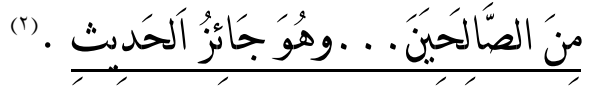

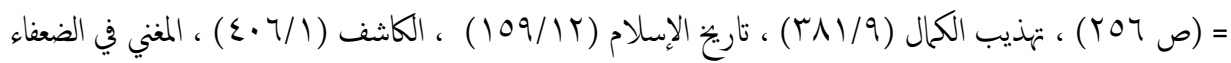

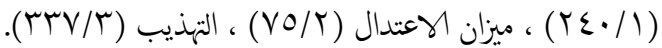

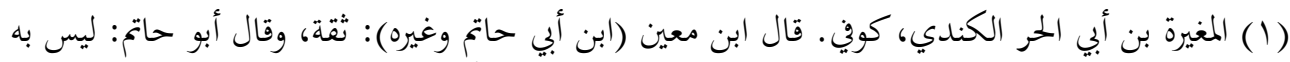

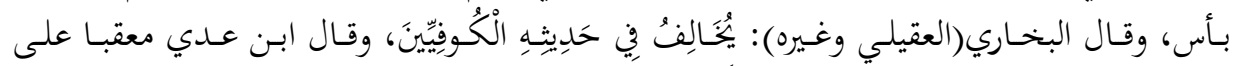

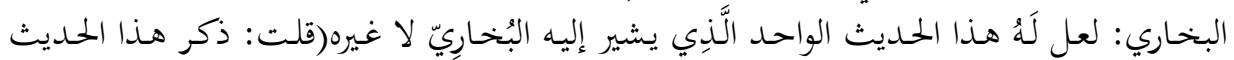

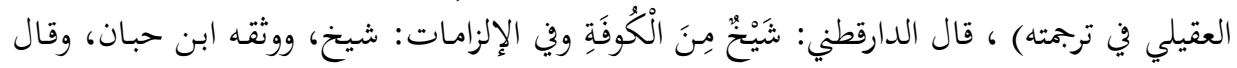

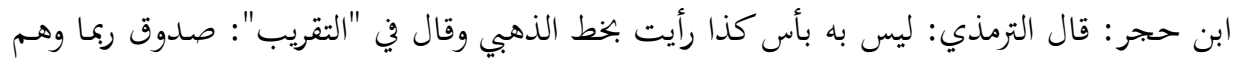

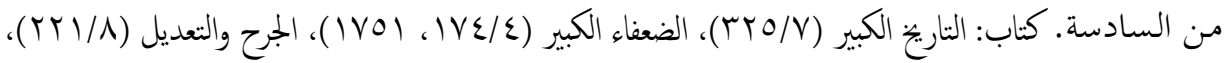

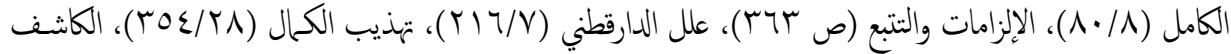

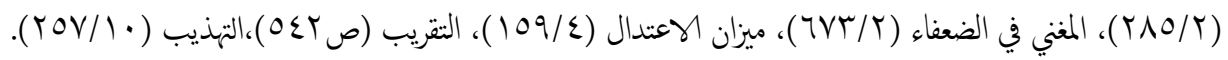

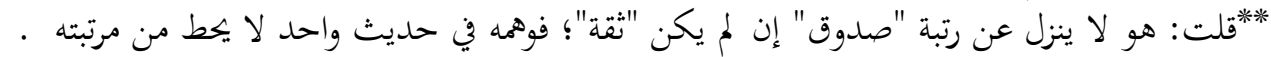

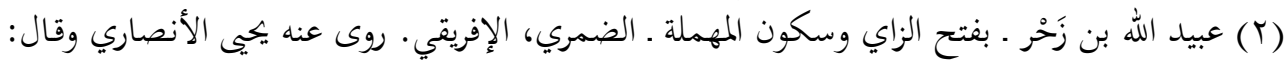

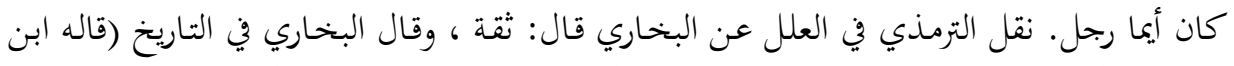

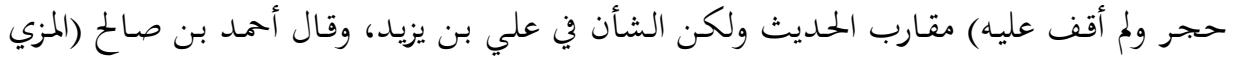

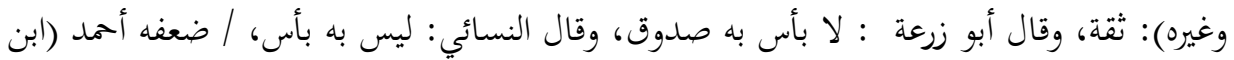

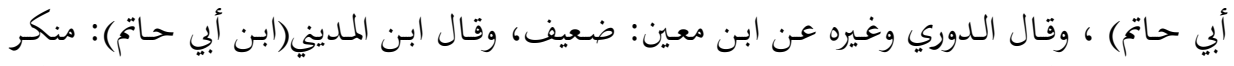

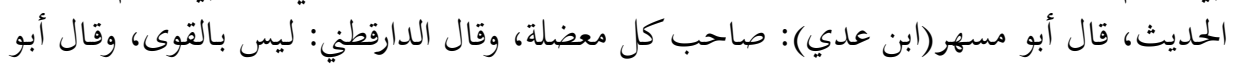

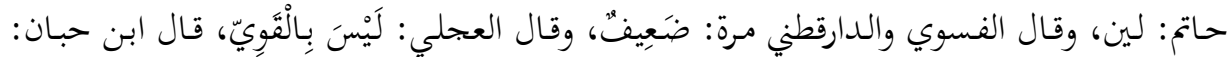

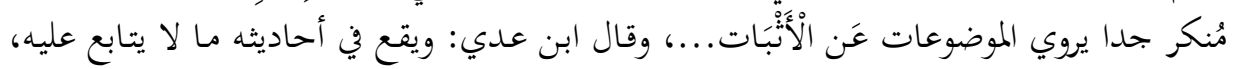

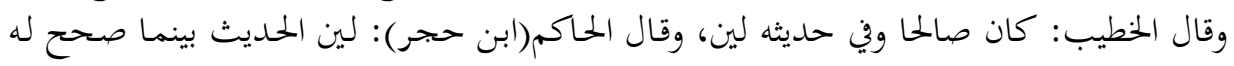

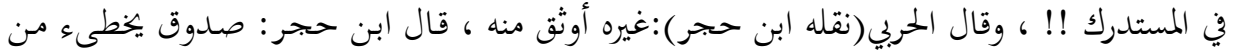

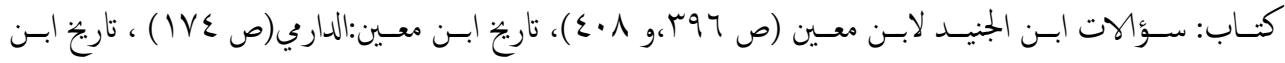

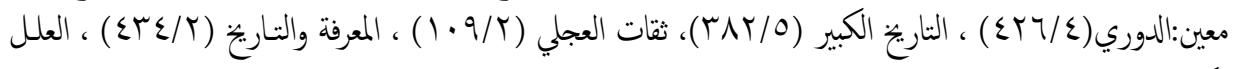

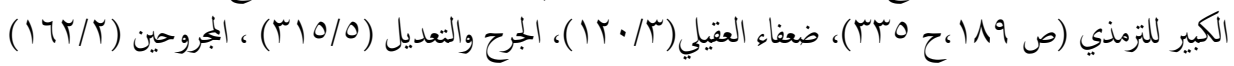

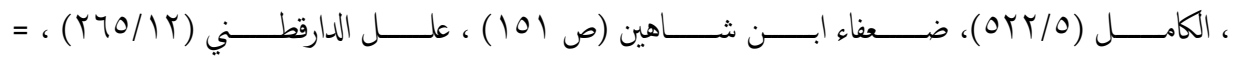




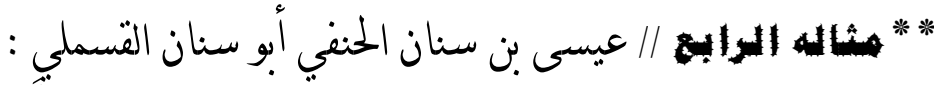

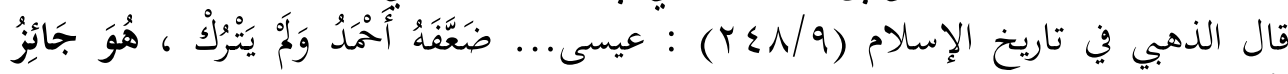

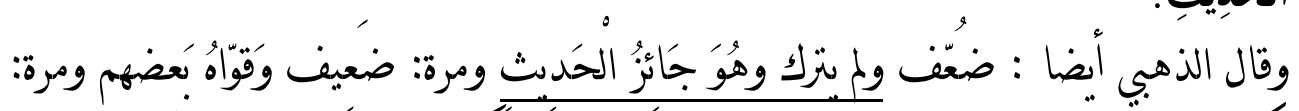

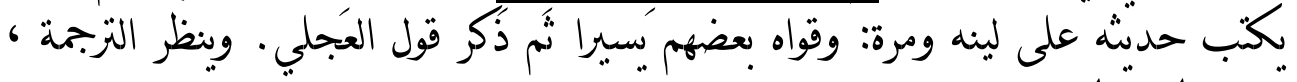

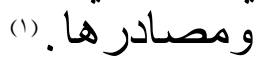

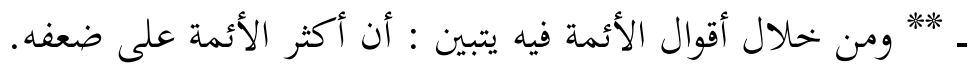

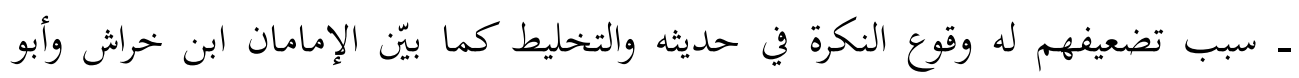
ـ أحاديثه يسيرة كما بيّن ابنُ عديّ ، وهذا يقدح في الراوي مع وقوع الخطأ منه.

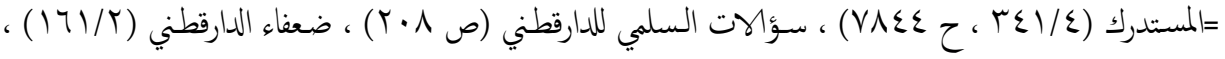

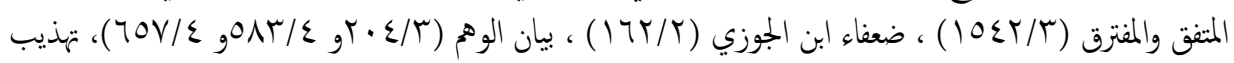

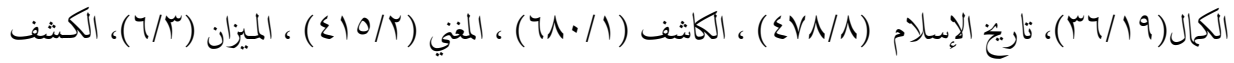

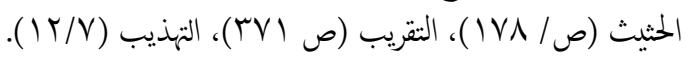

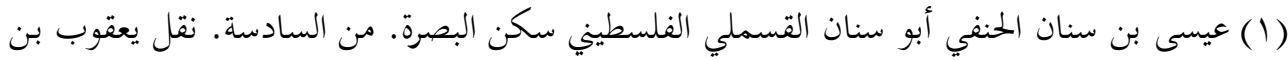

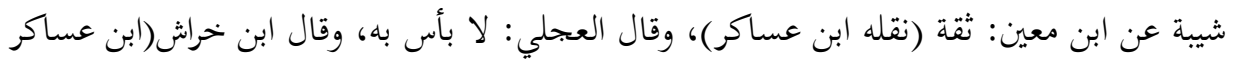

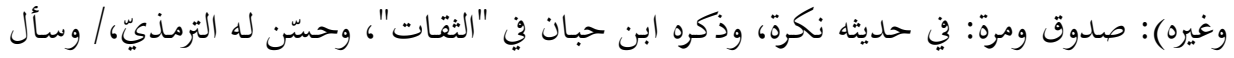

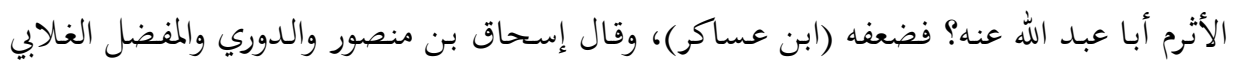

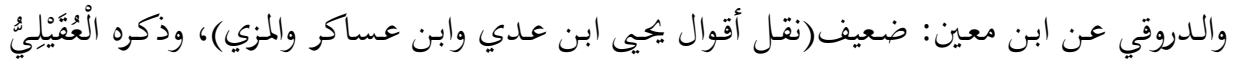

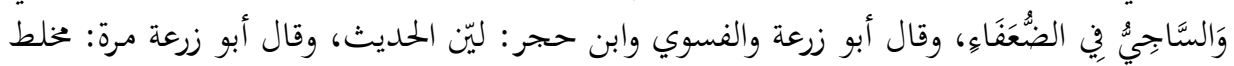

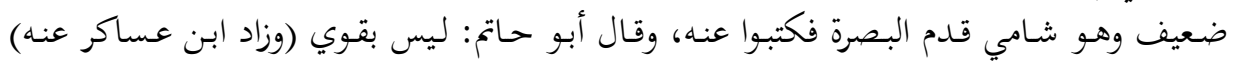

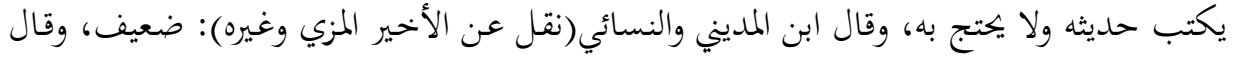

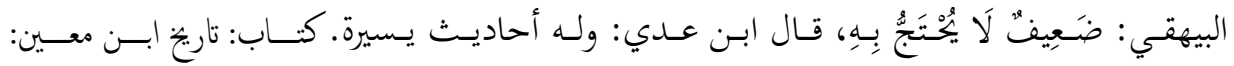

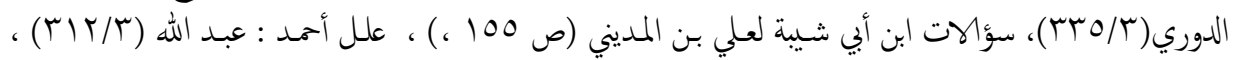

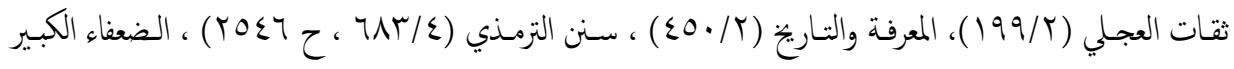

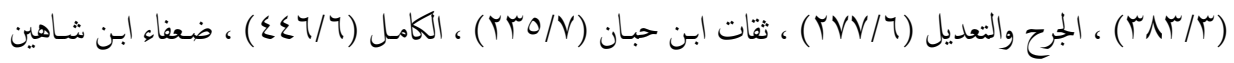

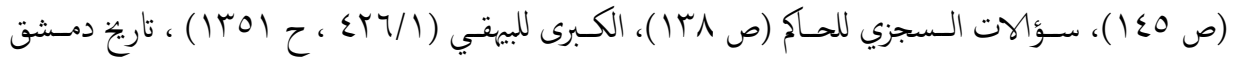

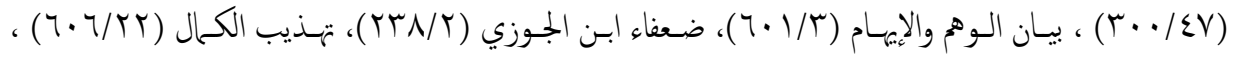

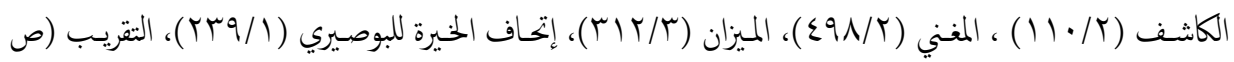




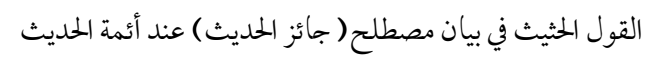

- وأما من وتِّهه.. فابن معين أكثر الروايات عنه وآخرها التضعيف ، وأما تحسين الترمذي

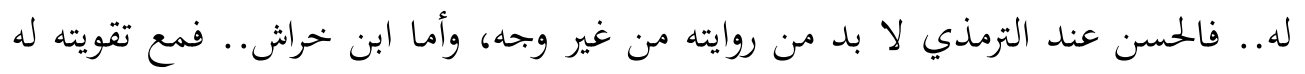

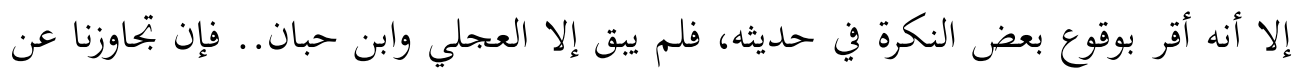

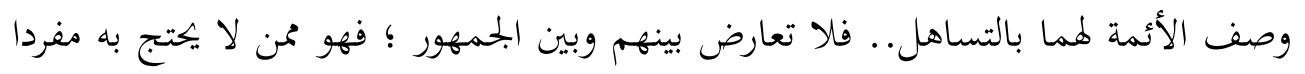

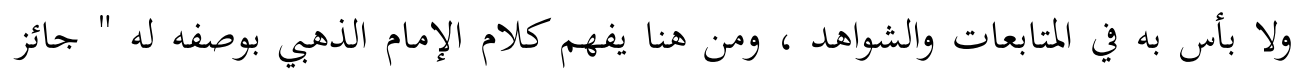

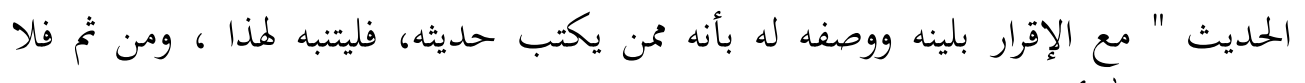

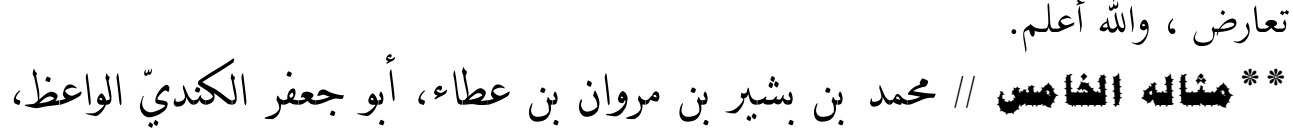

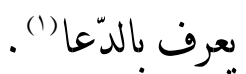

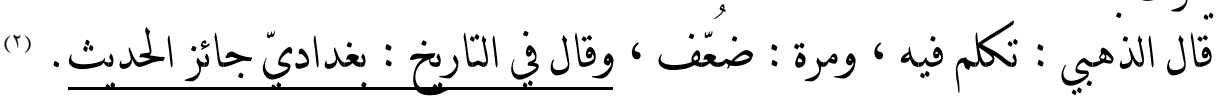

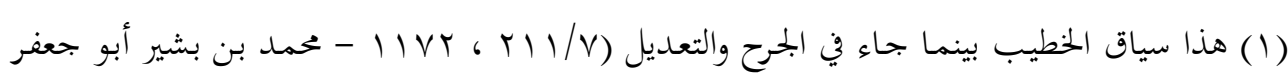

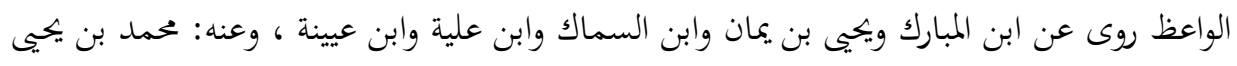

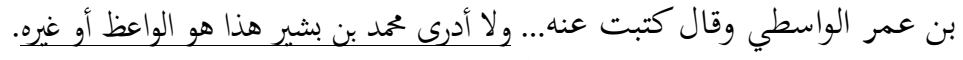

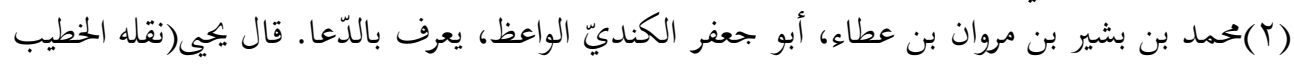

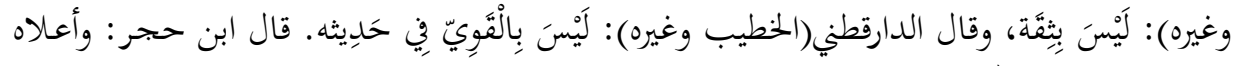

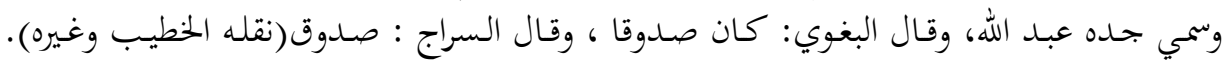
مات سنة ست وثلاثين ومائتين.

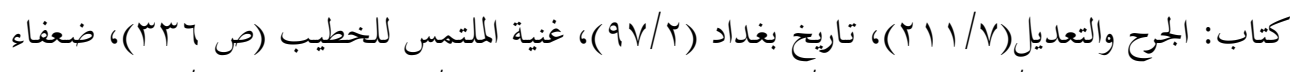

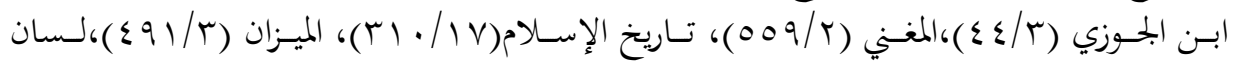

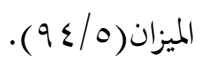

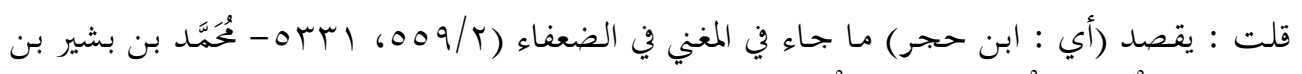

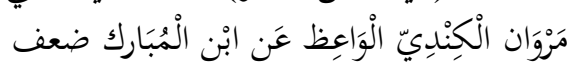

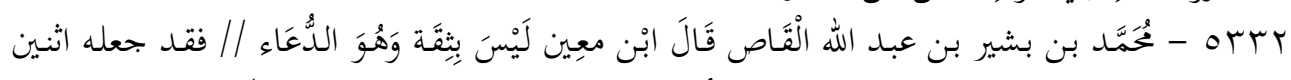

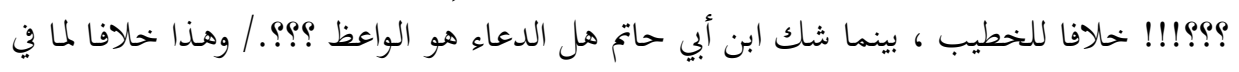

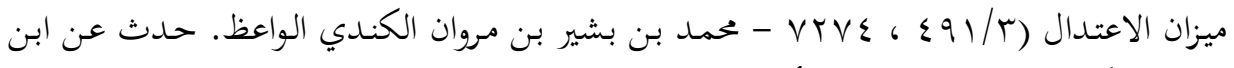

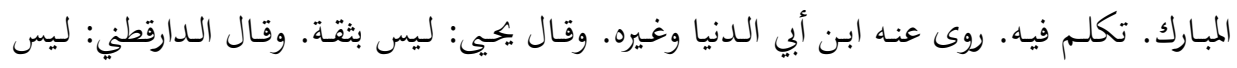

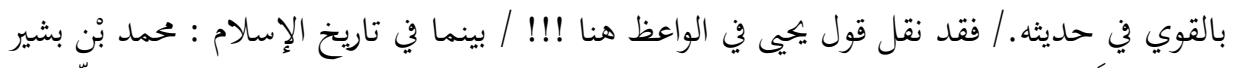

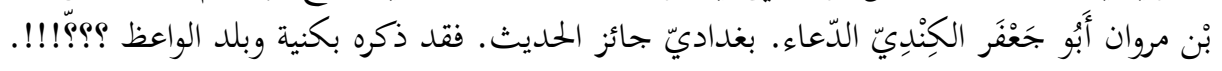




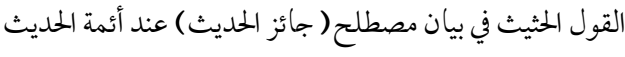

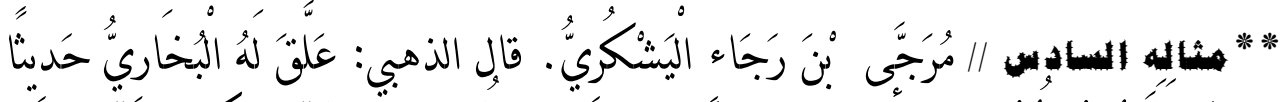

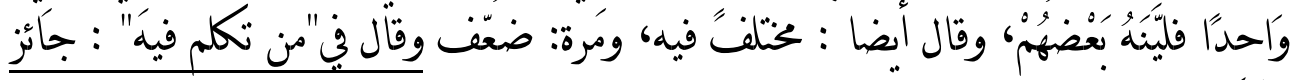

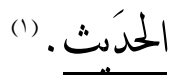

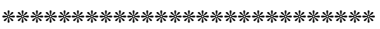

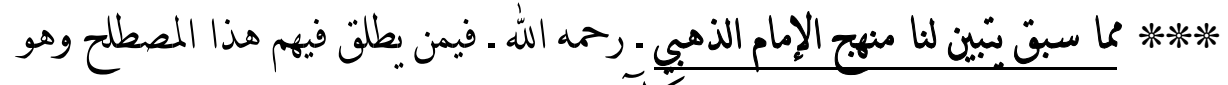
كالآتي :

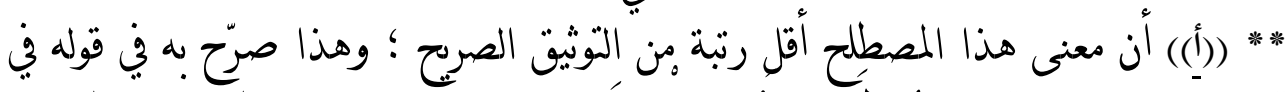

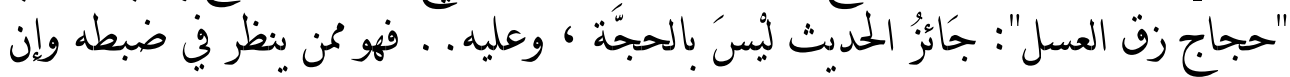
كان في مرتبة من يقبل روائهة ابنداًَّ.

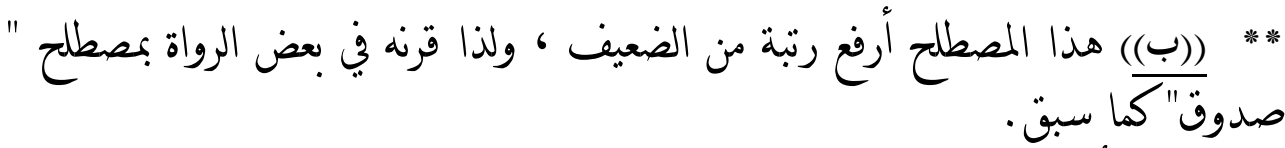
*** (ج) وأيضا بطلق هذا المصطلح في المستور الذي لميجرح ، وكذا في "المستور" الذي

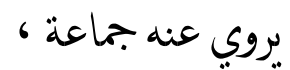
وهذان الصّنفان : المستور الذي يروي عنه جماعة، والمستور الذي لميجرح ، ننزلما الإمام

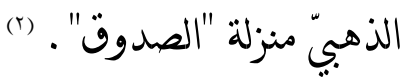

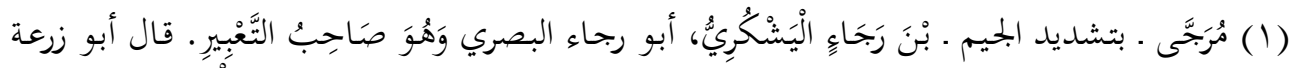

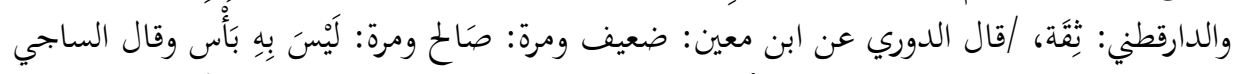

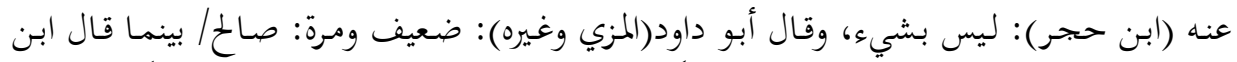

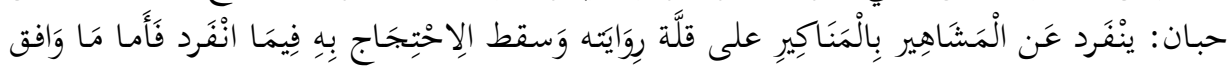

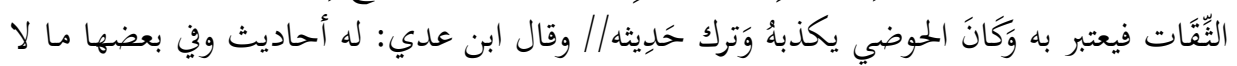

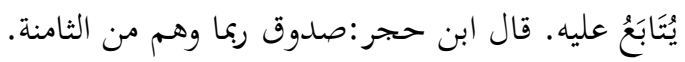

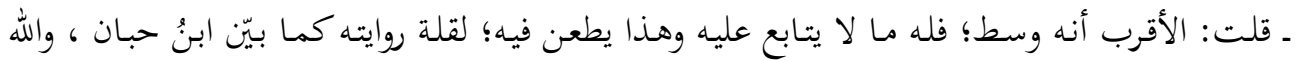

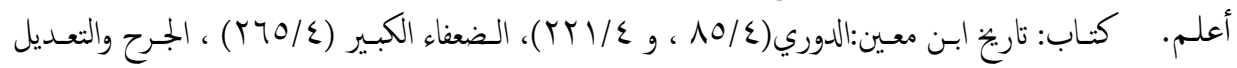

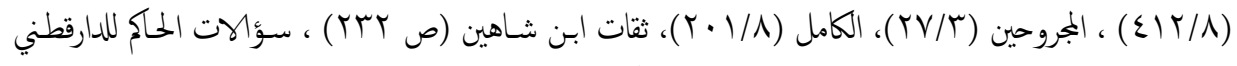

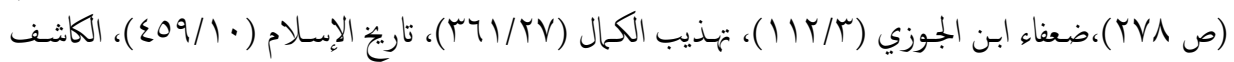

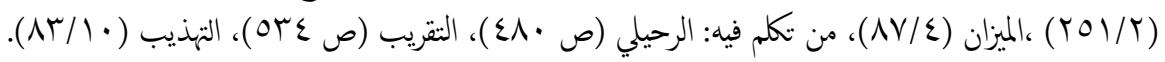

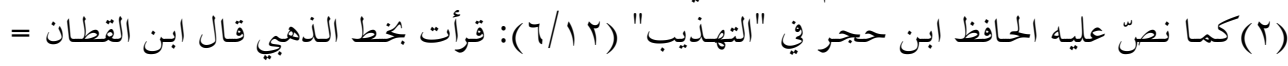




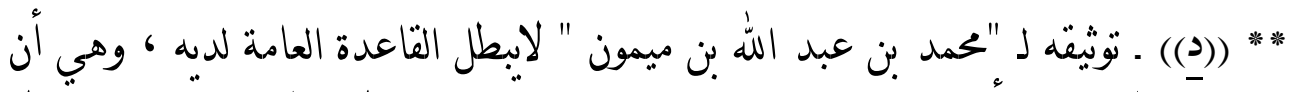

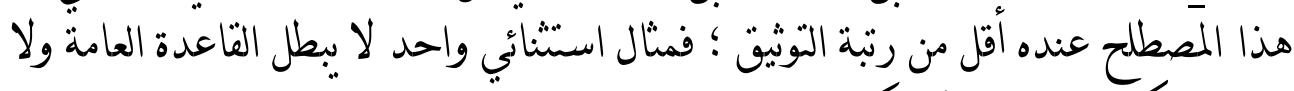
يردها؛ فلكل قاعدة استثناء كما هو معلوم.

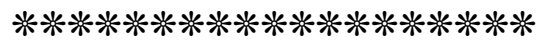

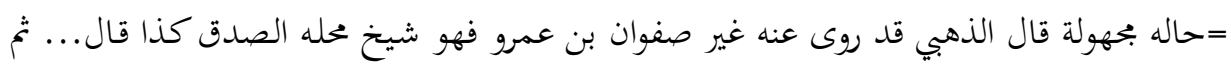

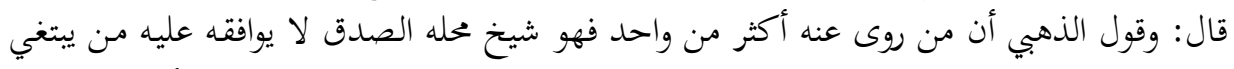

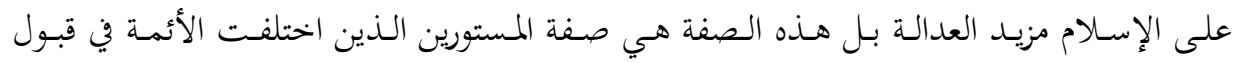

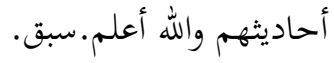

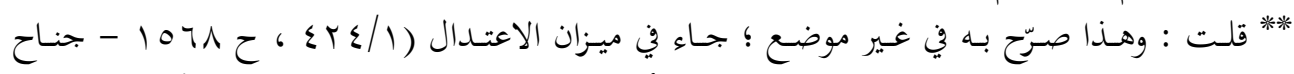

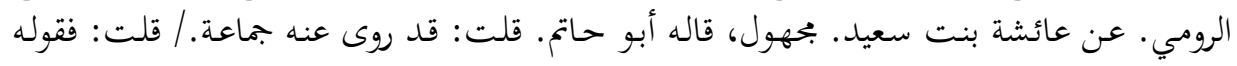
ظاهره الاعتراض على قول أبي حاتم كما ترى.

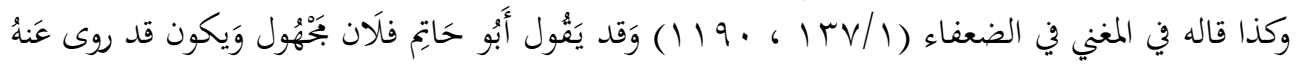
جمَاعَة

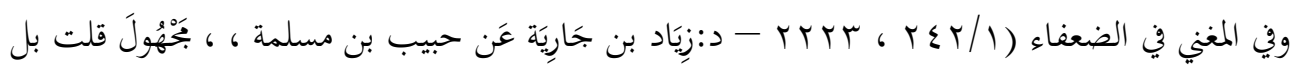
صَدُوق روى عَنْهُ جمَاعَة.

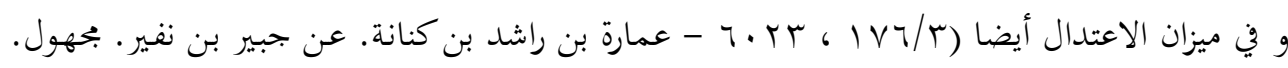

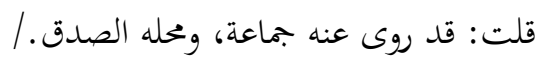

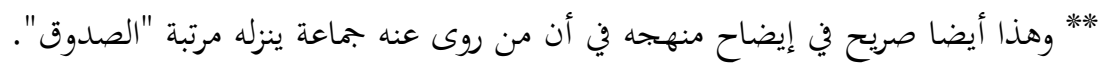

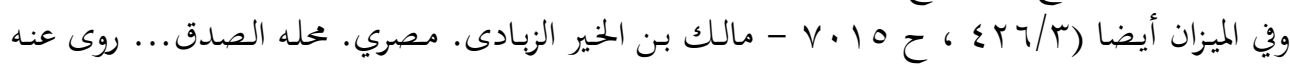

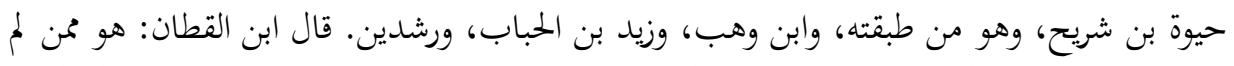

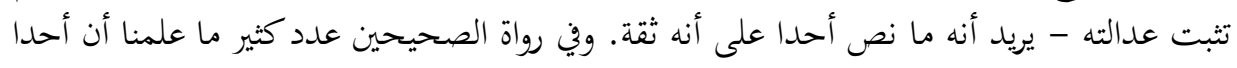

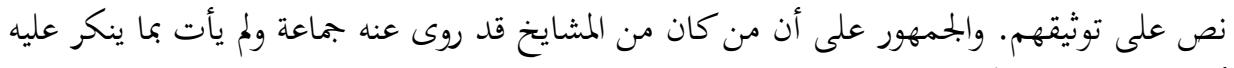

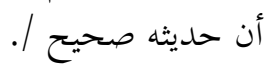

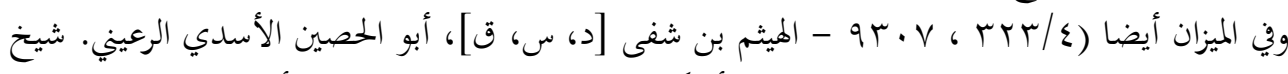

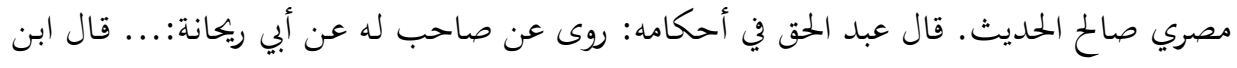

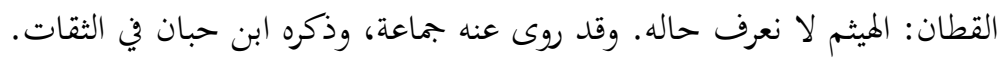

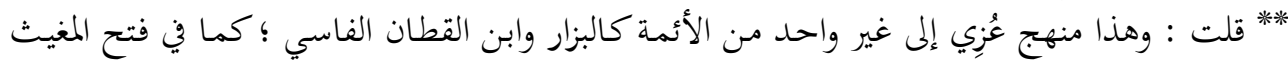

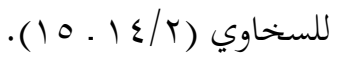




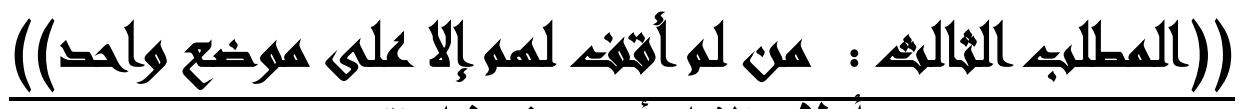

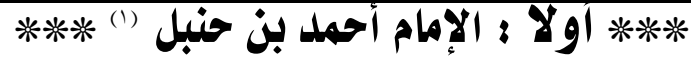

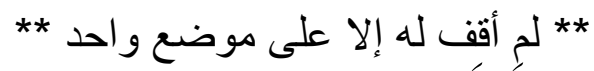

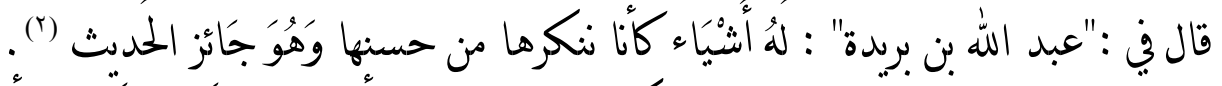

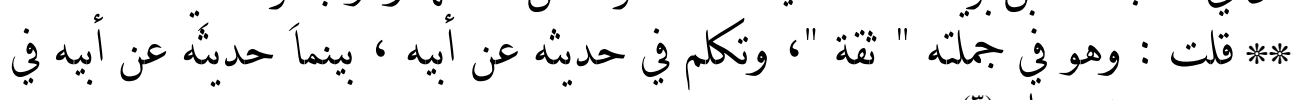

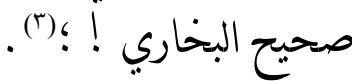
- وقد روى له الجماعة، وكل من تخلم عليه وثقه ـ كما في ترجمه ـ ، ووصفه الذهبي

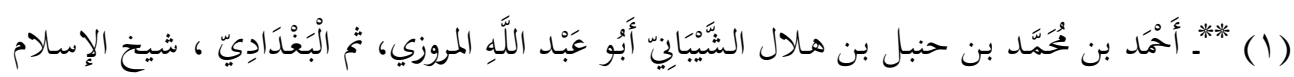

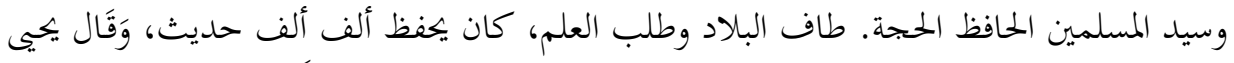

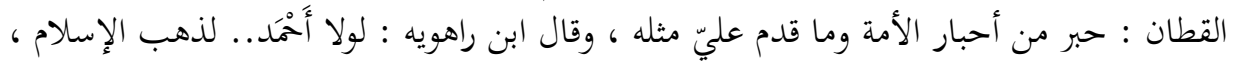

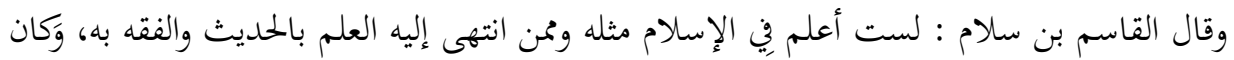

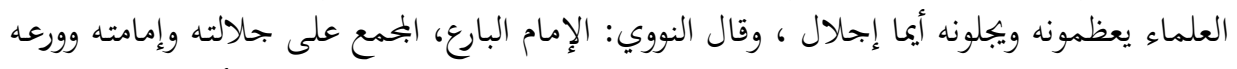

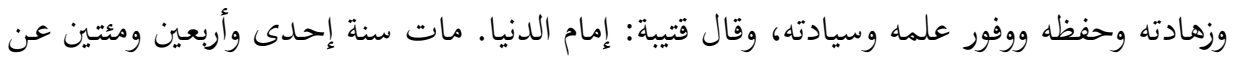

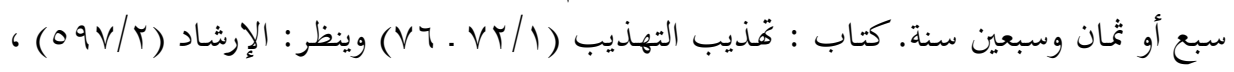

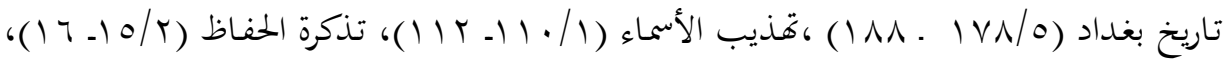

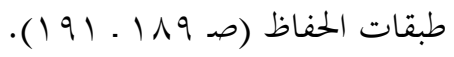

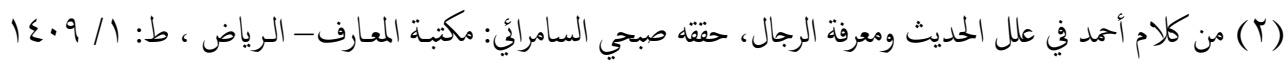

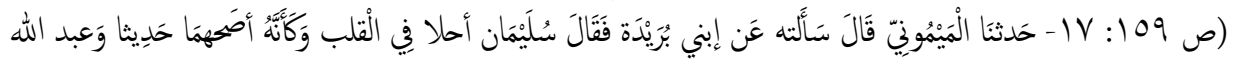

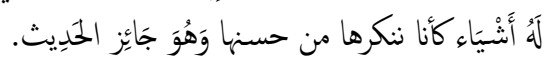

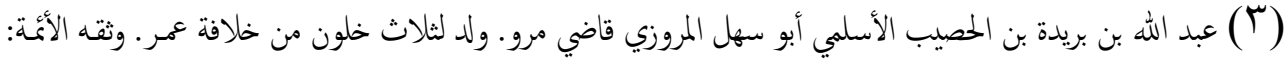

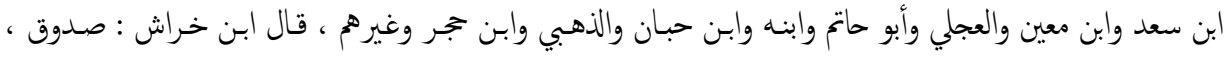

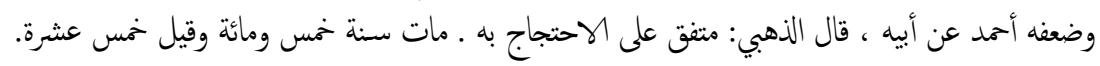

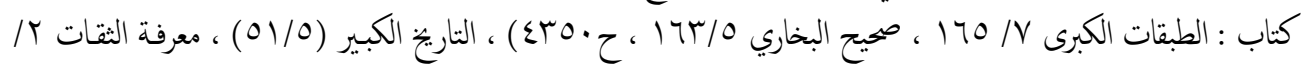

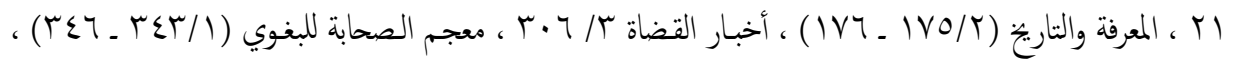

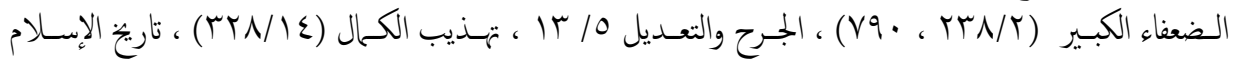

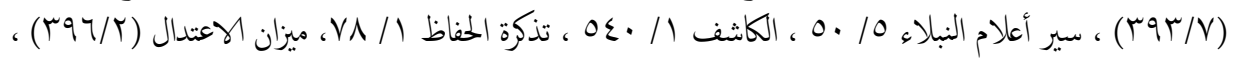

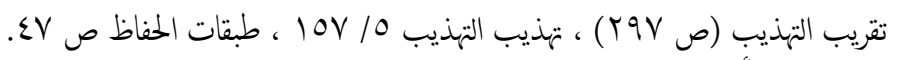

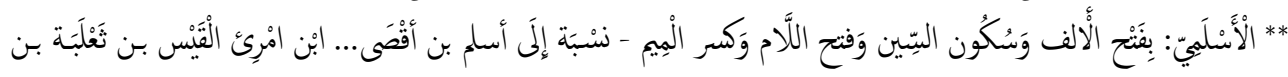

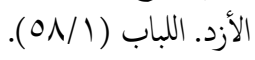
** المروزي : بفتح الميم وسكون الراء وفتح الواو وفي آخراهـا زاي هذه النسبة إلى مرو الشاهجان. اللباب في تهذيب

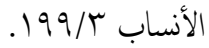




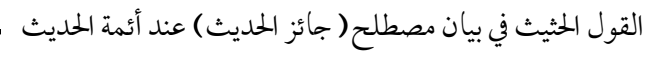

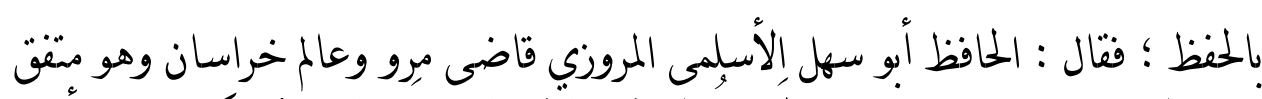

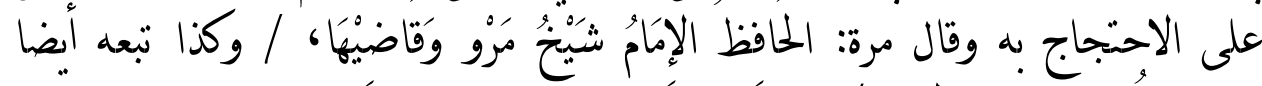

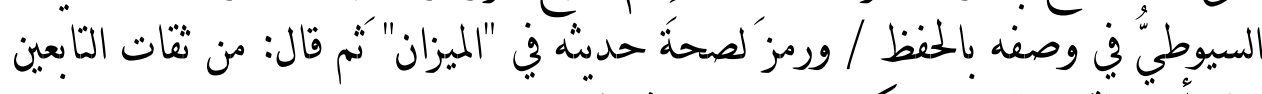

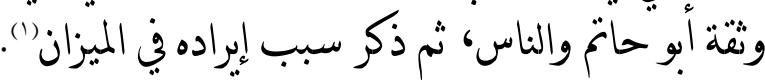

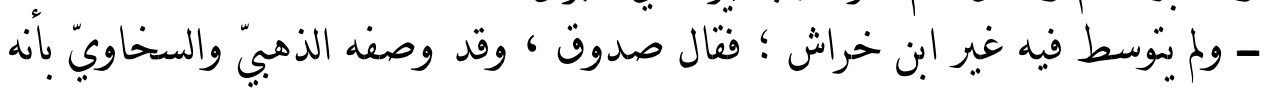

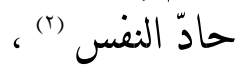

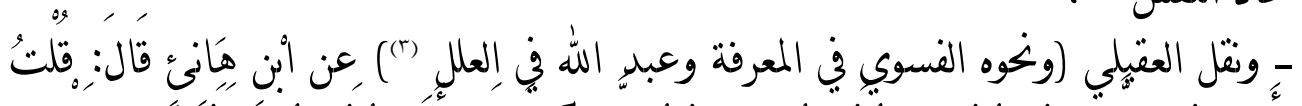

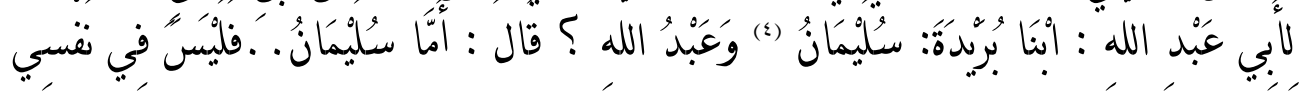

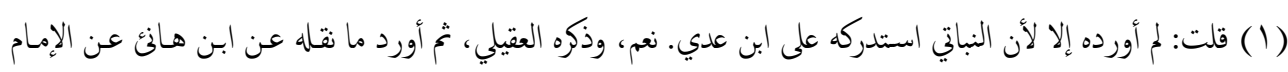

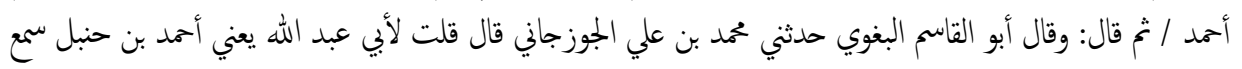

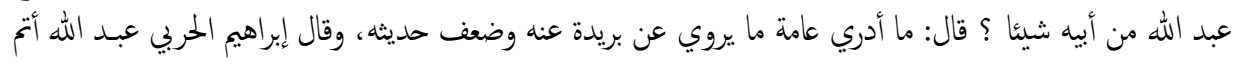

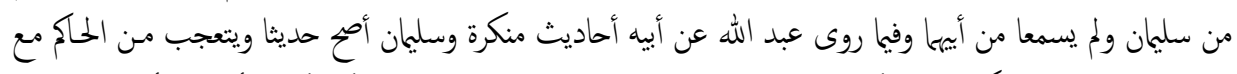

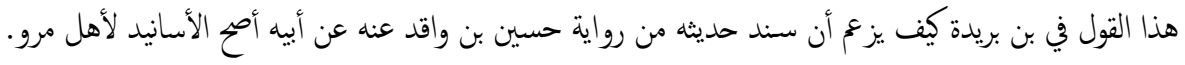

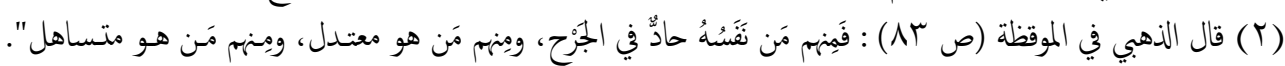

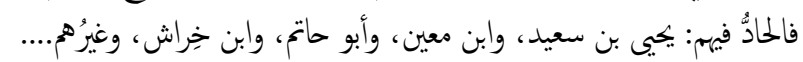

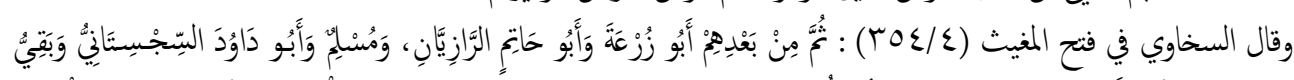

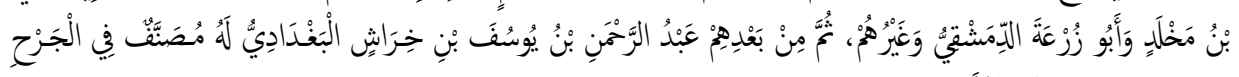

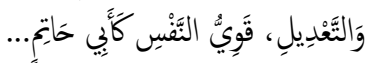

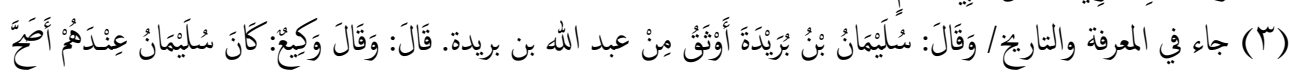
حَرِينًا.

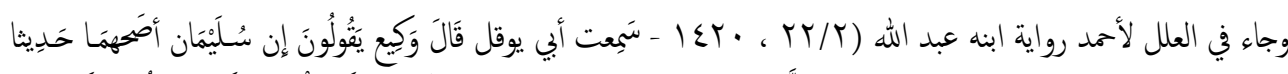

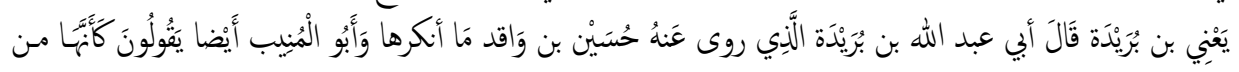
قبل هَوُْلَاهِ.

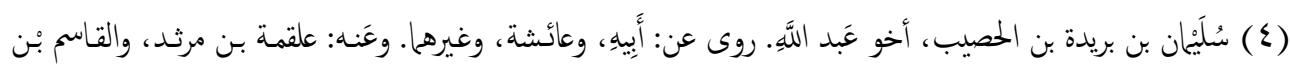

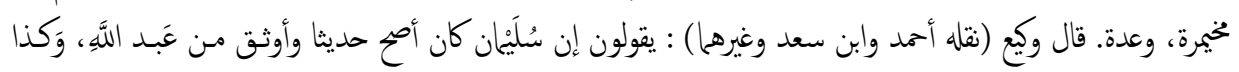

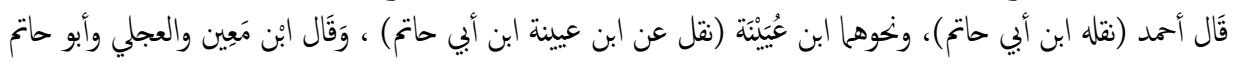

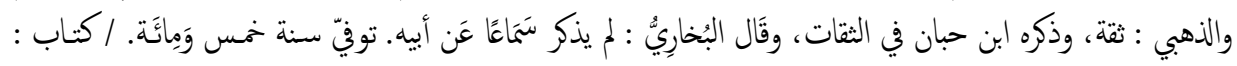

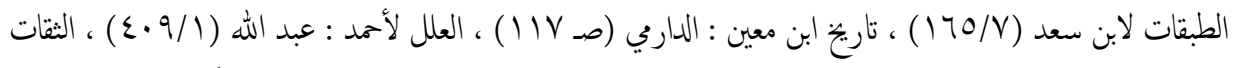

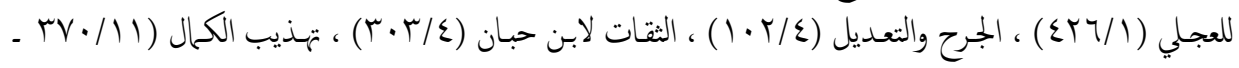

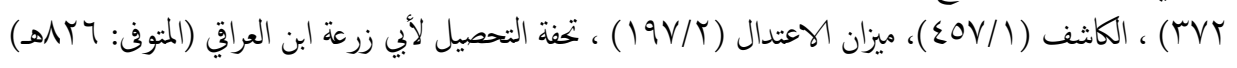

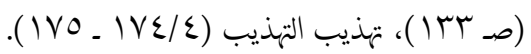



القول الحثيث في بيان مصطلح ( جائز الحديث) عند أئمة الحديث العزيث

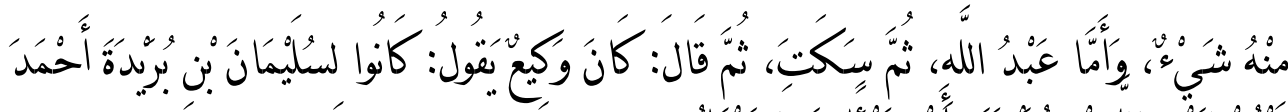

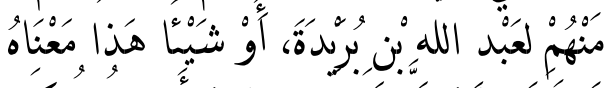

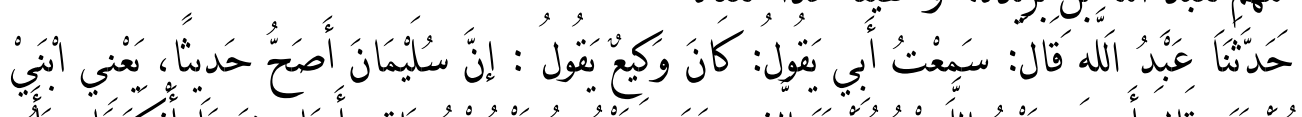

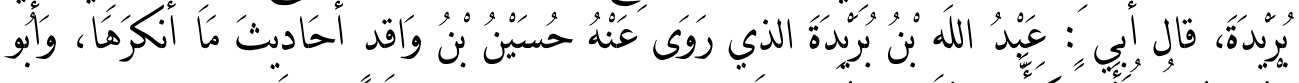

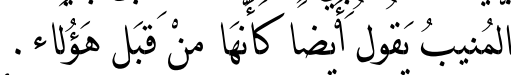
-

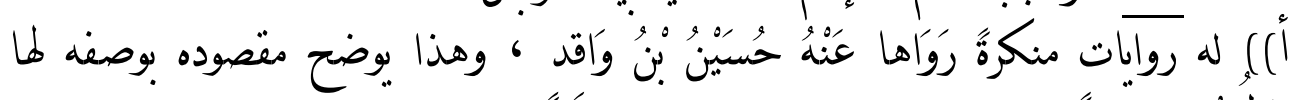

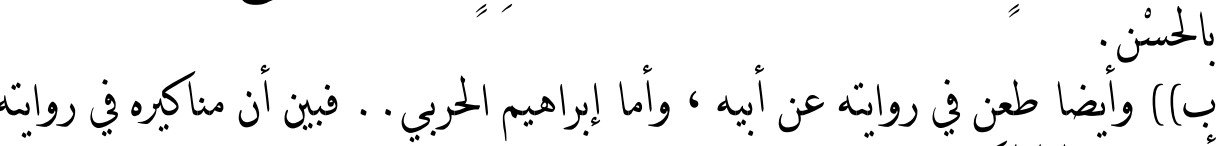

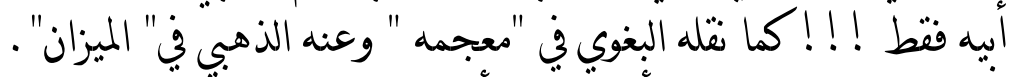

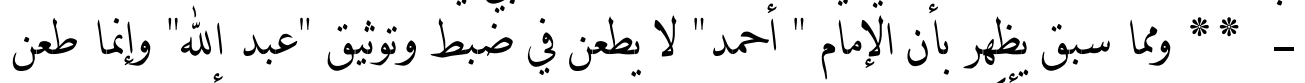

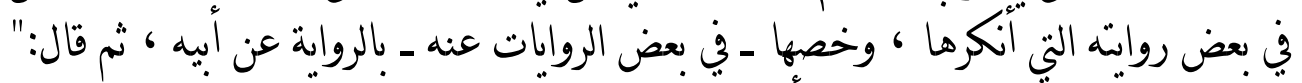

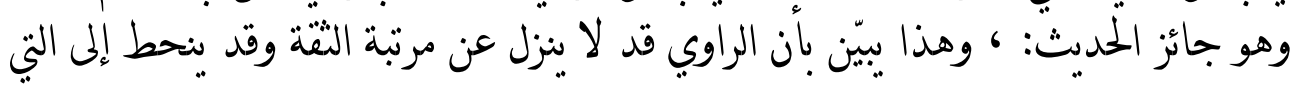

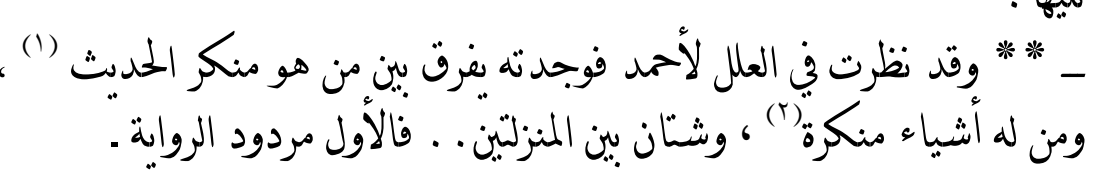

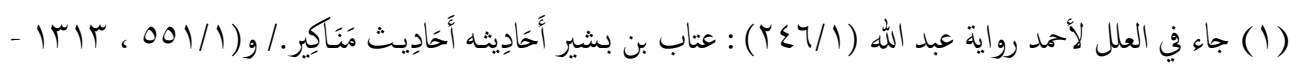

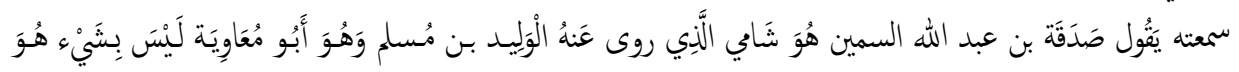

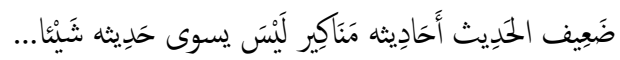

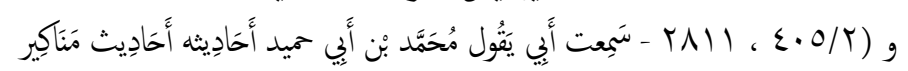

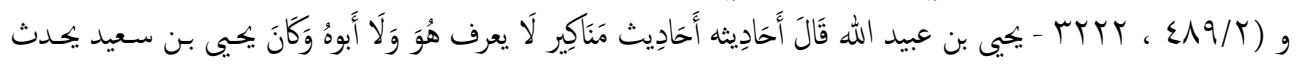
عَنُْ

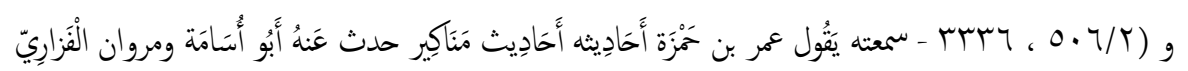

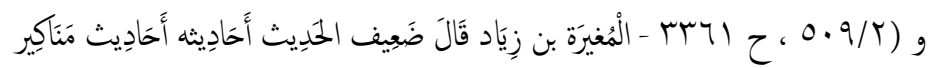

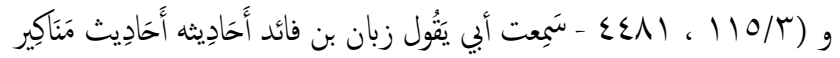

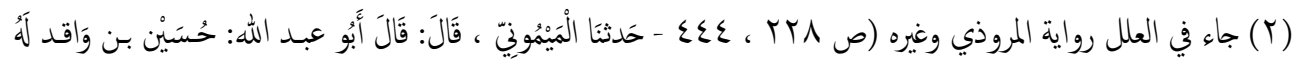
أَشْبَاء مَنَاكِير.

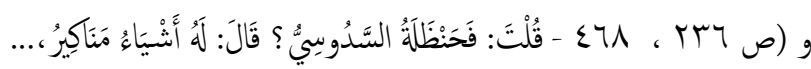

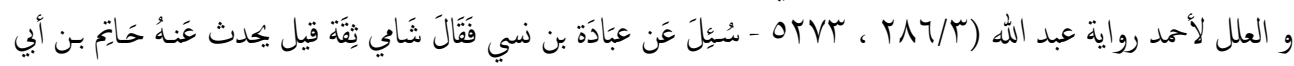

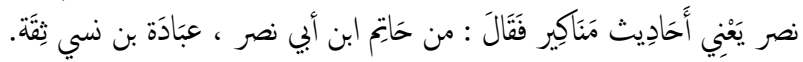




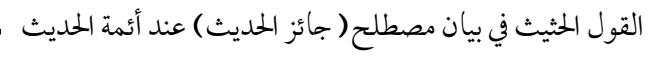

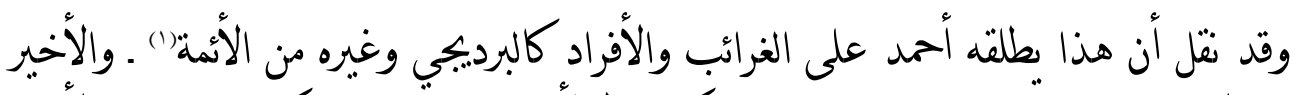

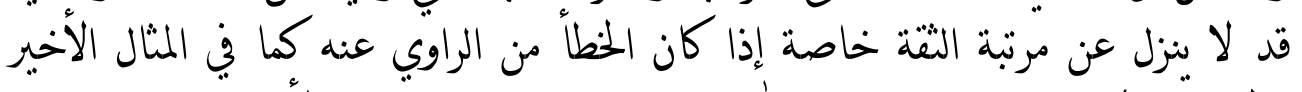

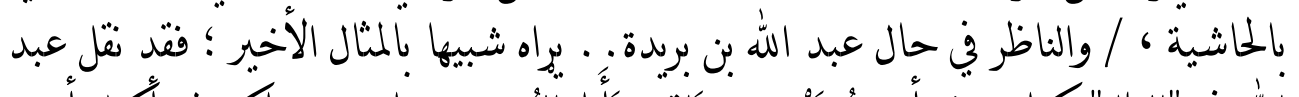

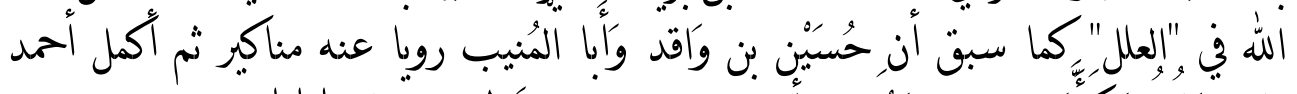

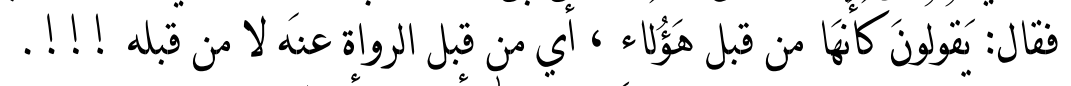

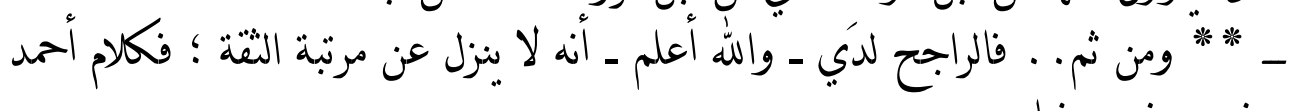

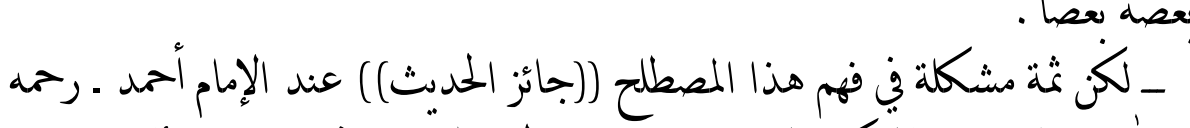

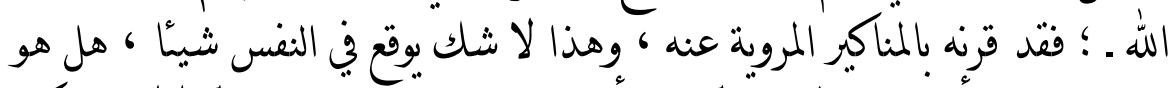

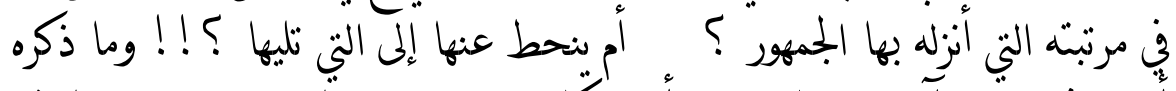

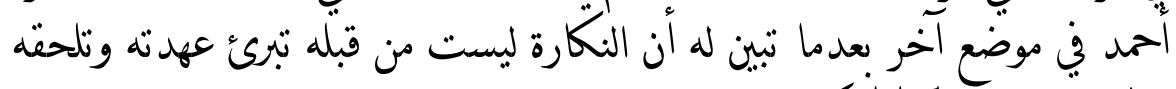

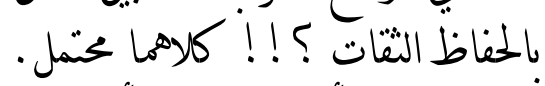

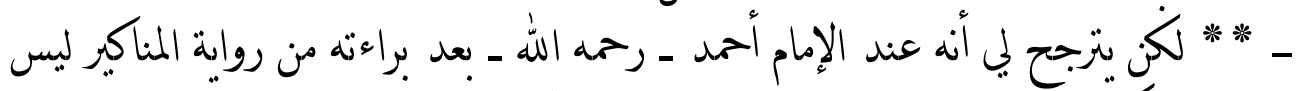

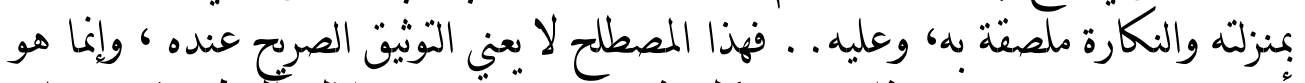

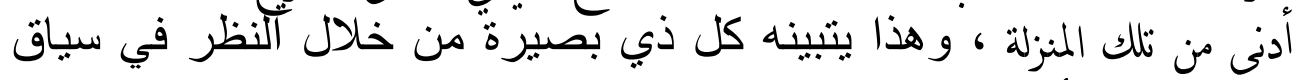

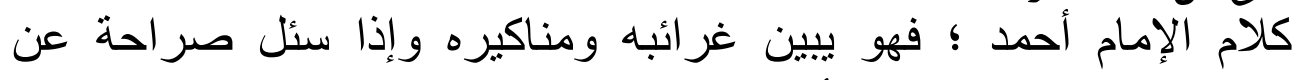

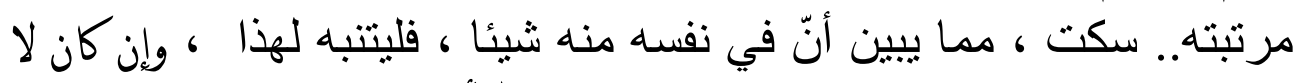
يخزج عن دائرة التوثيق الذي يترتب عليه قبول روايته، والله أعلم. 米洸洸洸档

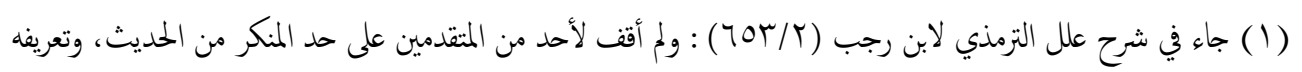

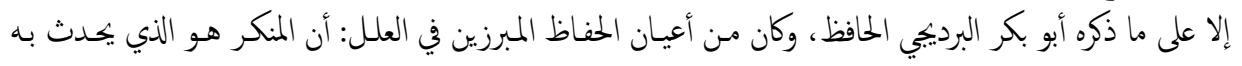

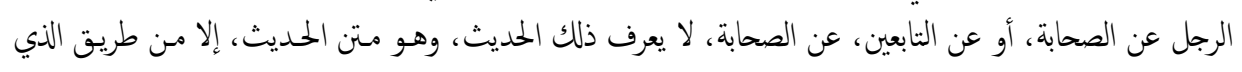
رواه فيكون منكراً. ذكر هذا الكلام في سياق ما إذا انفرد شعبة أو سعيد بن أبي عروبة أو هشام الدستوائي بحديث عن قتادة، عن أنس، عن النبي - صلى الله عليه وسلم -. وهذا كالتصريح بأن كل ما ينفرد به ثقة عن ثقة ولا يعرف المتن من غير ذلك الطريق فهو منكر، كما قاله الإمام أحمد.... 


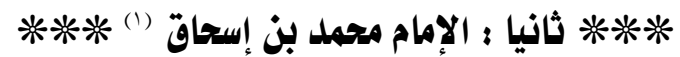

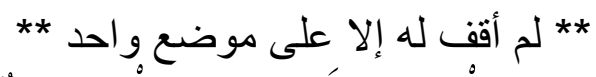

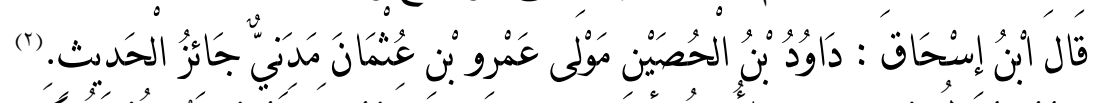

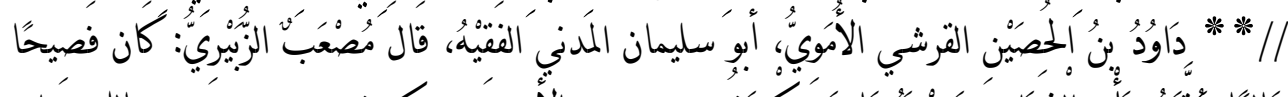

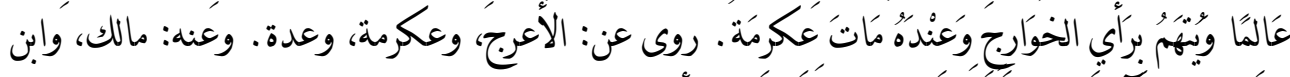

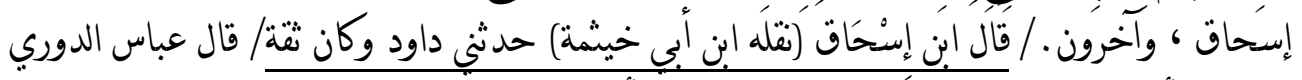

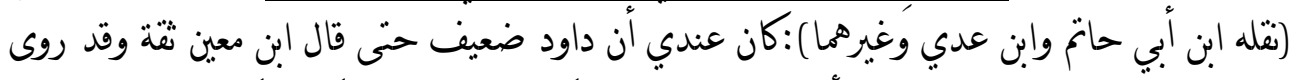

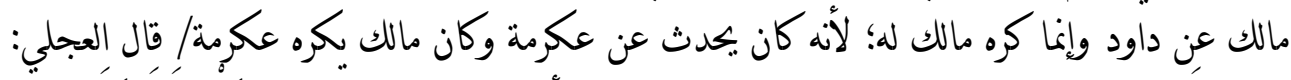

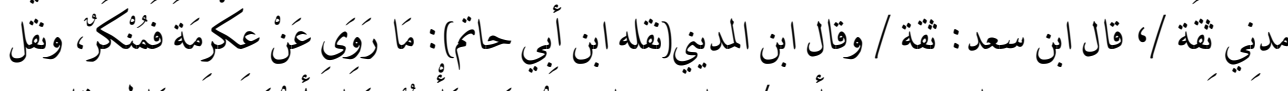

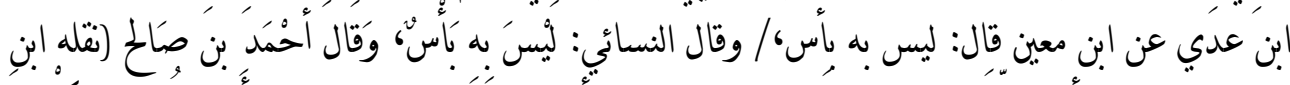

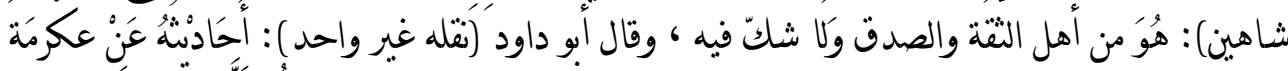

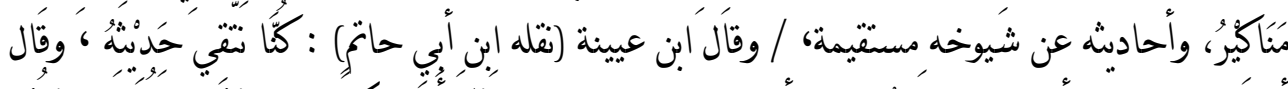

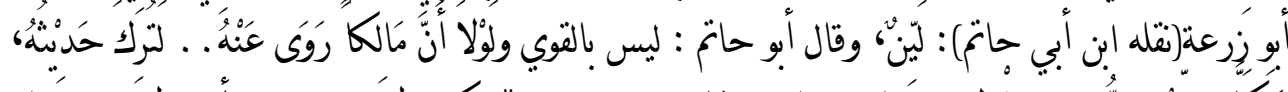

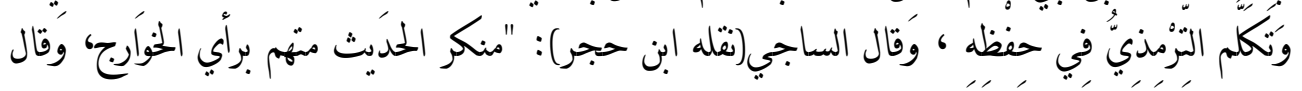

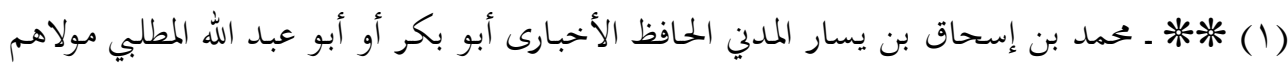

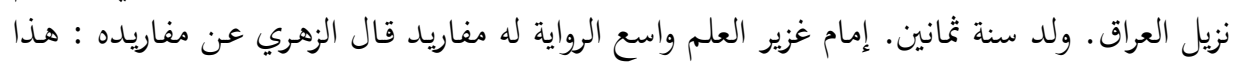

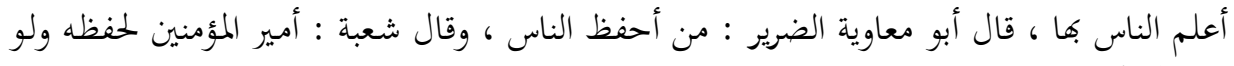

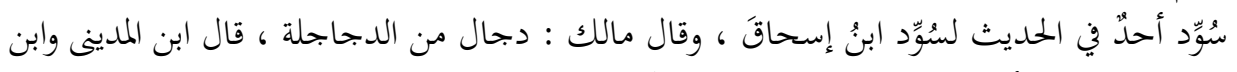

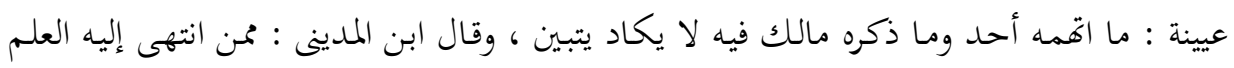

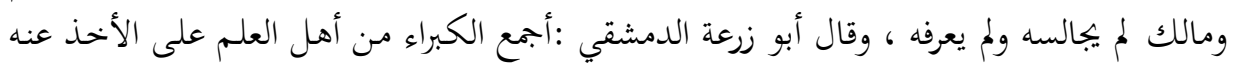

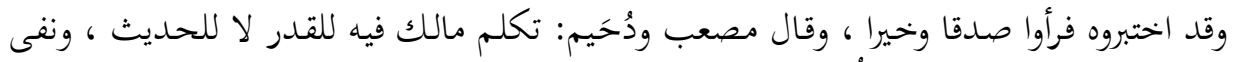

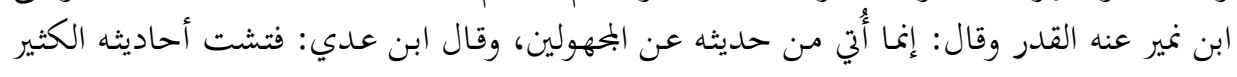

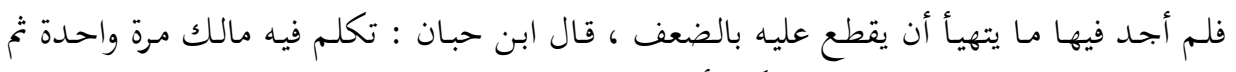

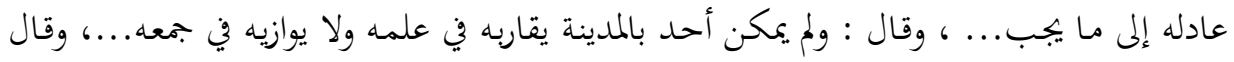

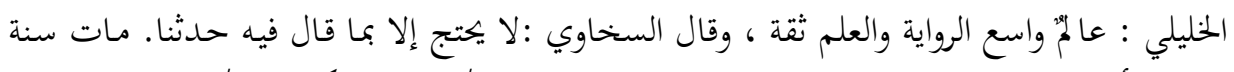

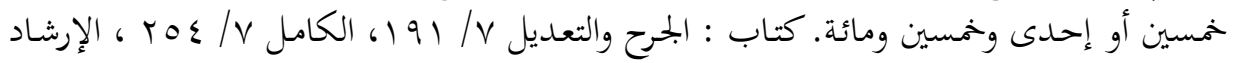

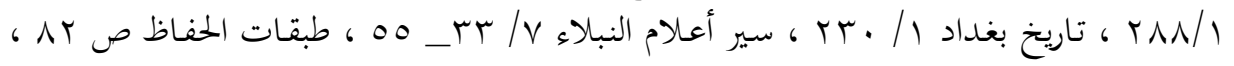

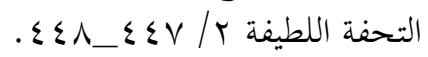

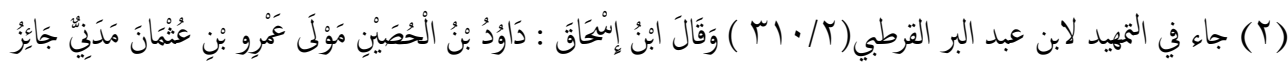

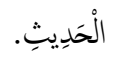

\section{$1 \cdot$ ro}



القول الحثيث في بيان مصطلح ( جائز الحديث) عند أئمة الحديث

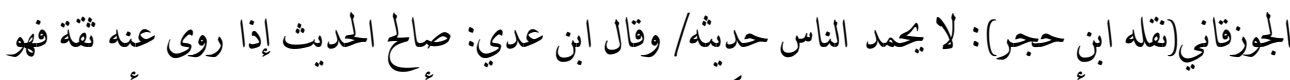

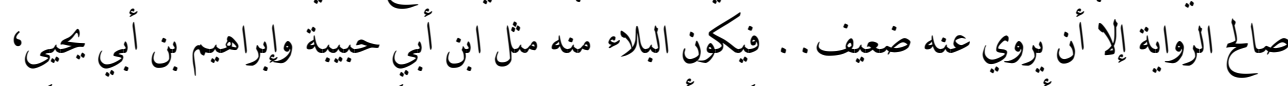

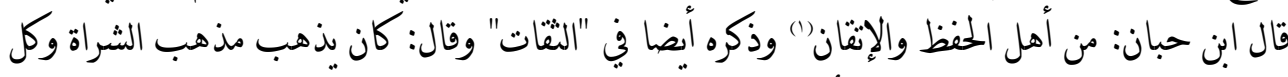

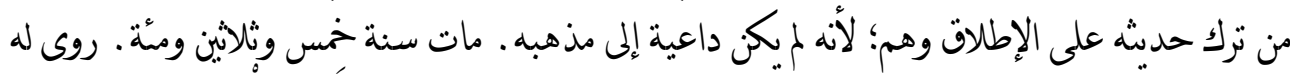

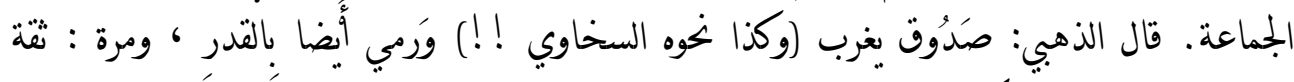

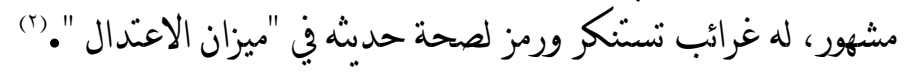

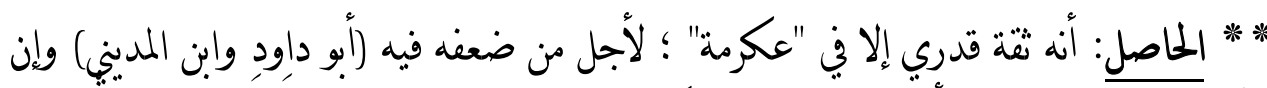

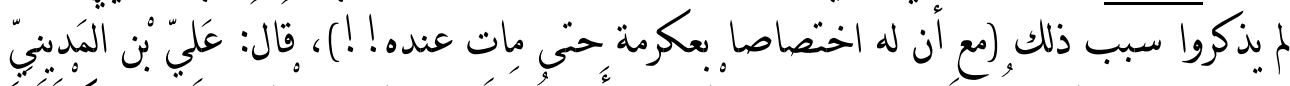

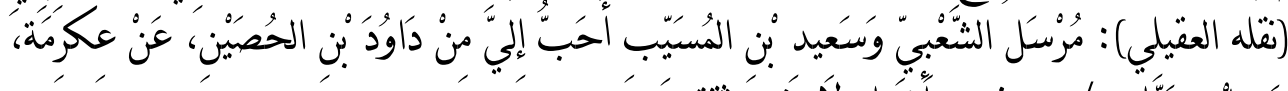

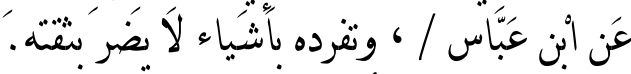

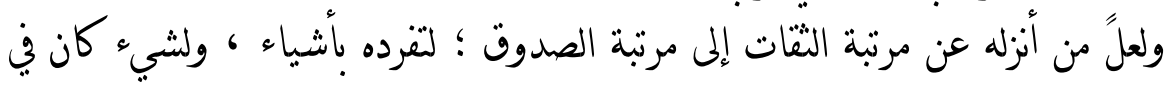

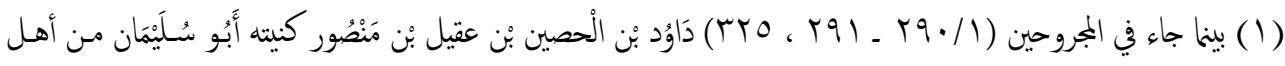

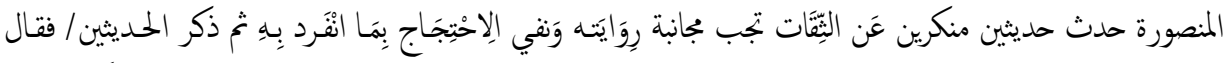

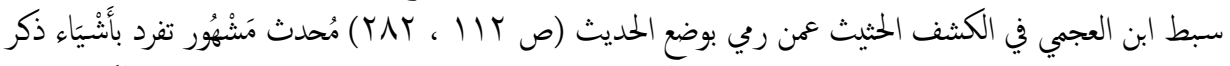

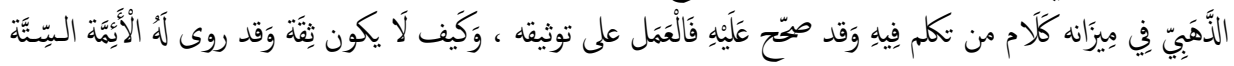

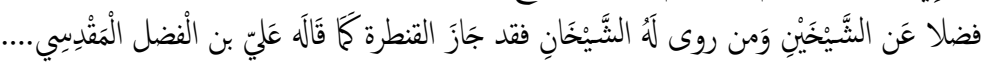

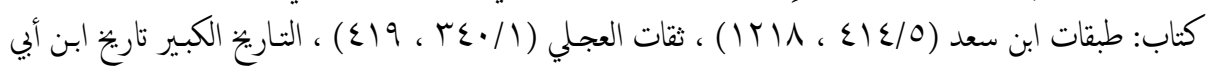

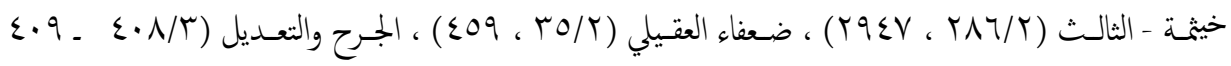

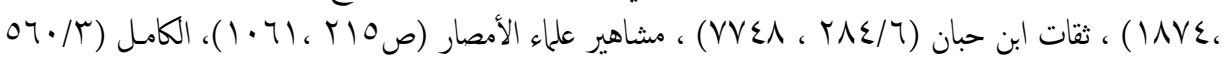

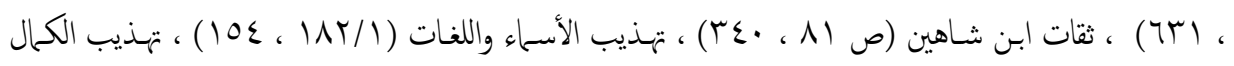

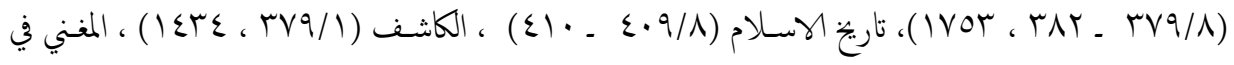

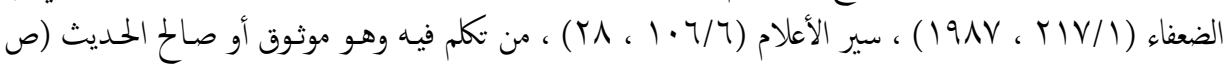

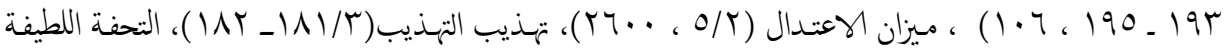

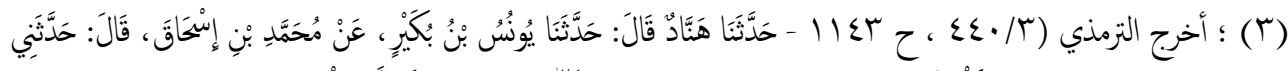

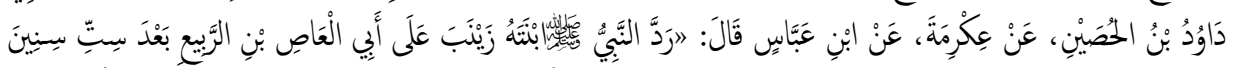

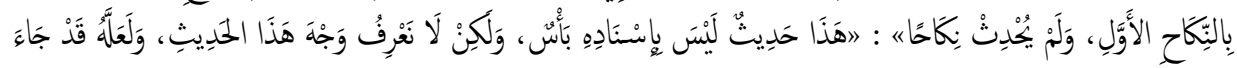

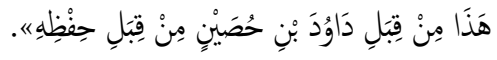



القول الحثيث في بيان مصطلح ( جائز الحديث) عند أئمة الحديث

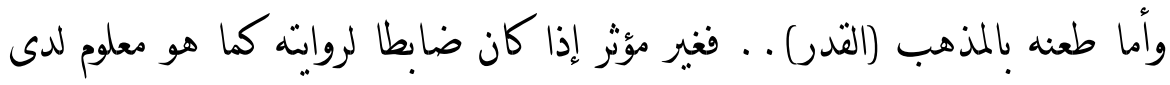

$$
\text { المشخصصين. }
$$

وكذا عند من قبل رواية غير الداعية إلى مذهبه ولم يكنى داعية ؛ كما بِّنه ابن حبان.

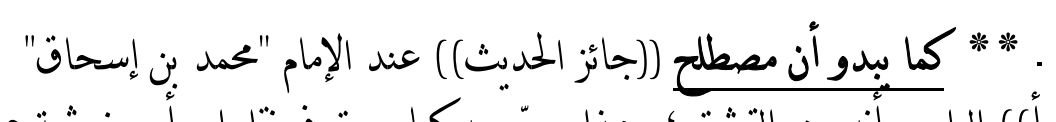

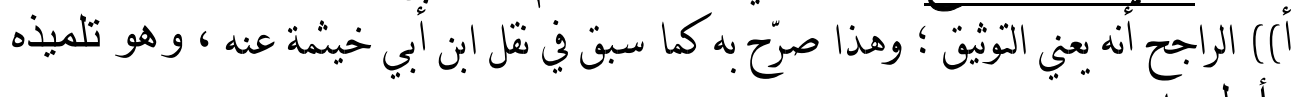

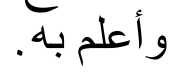

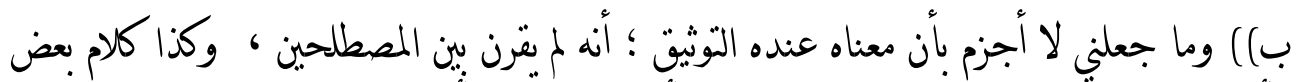

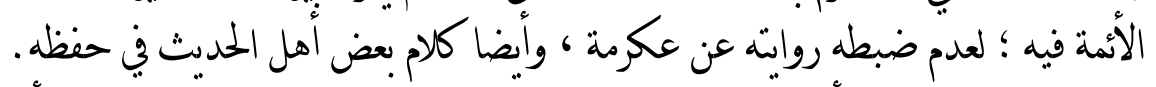

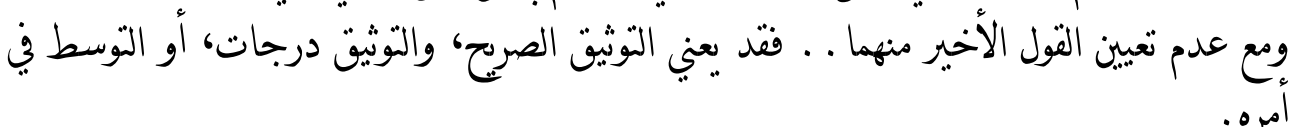

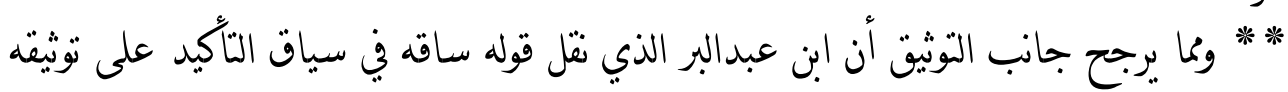
وقبول روايّه.

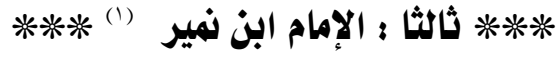

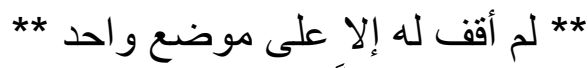

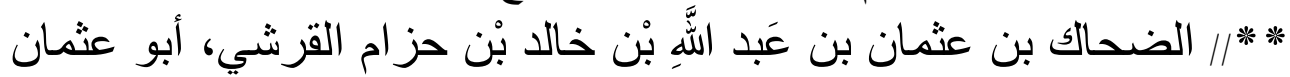

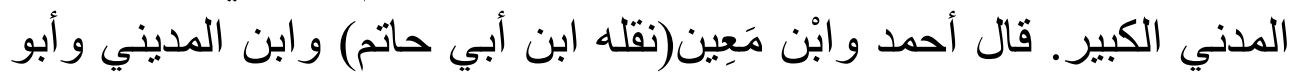

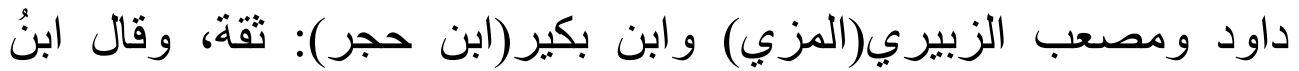

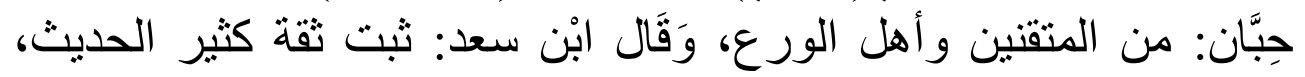

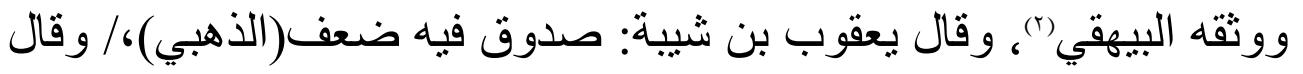

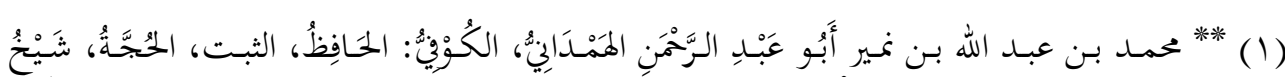

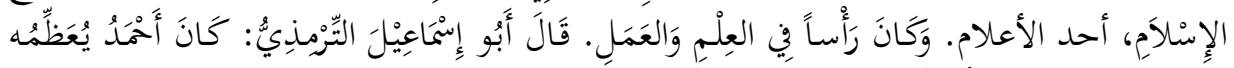

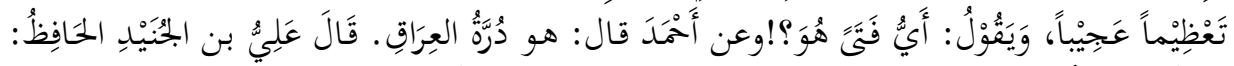

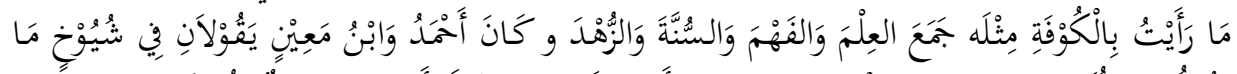

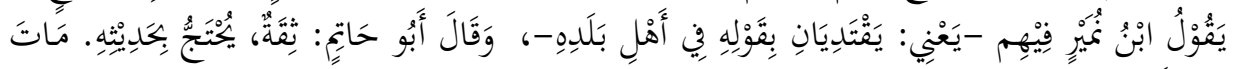

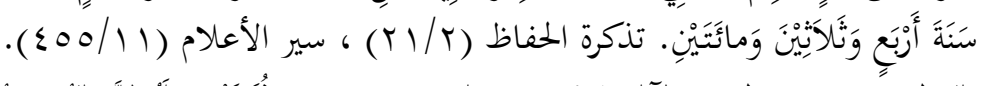

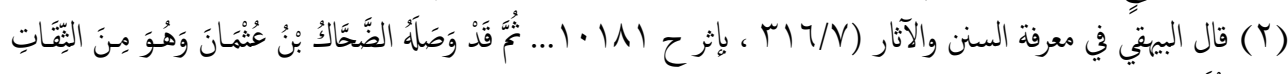

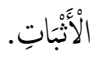



القول الحثيث في بيان مصطلح ( جائز الحديث) عند أئمة الحديث العزيث

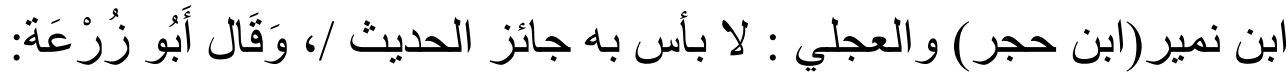

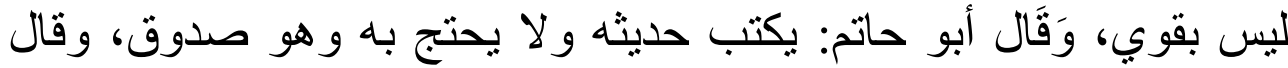

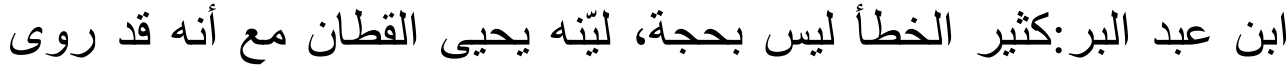

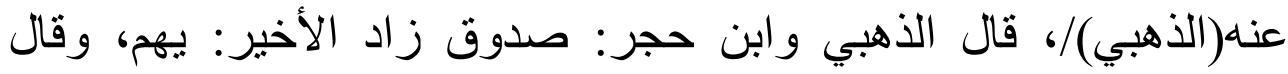

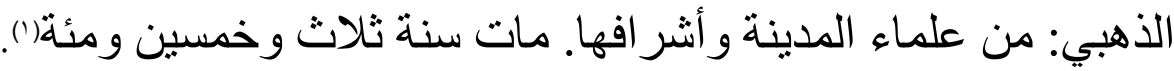

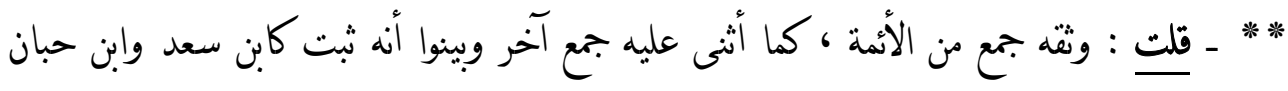
والبيهتي.

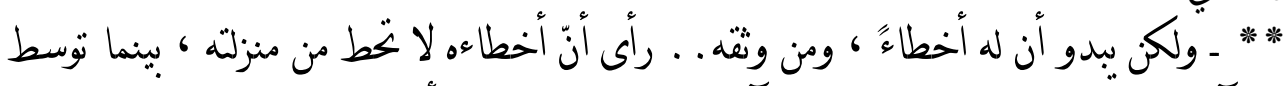

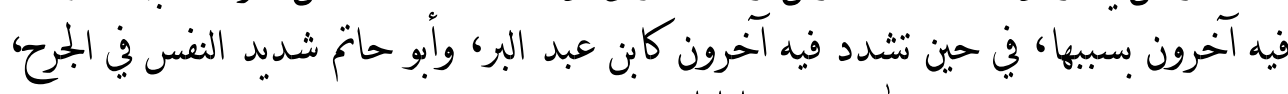

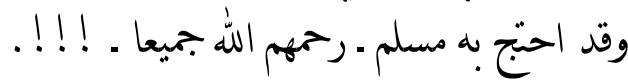

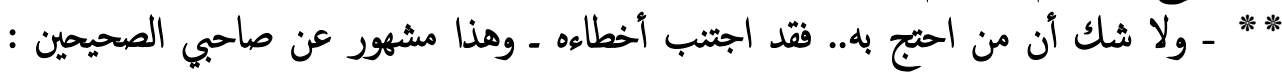

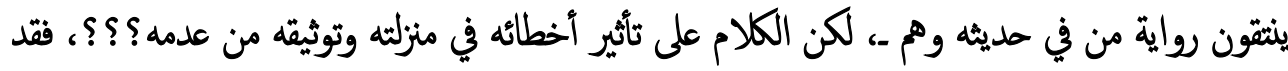

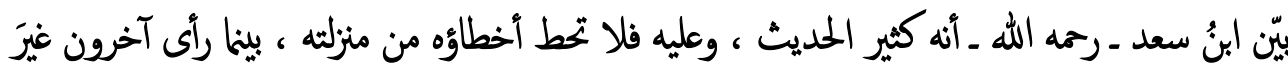

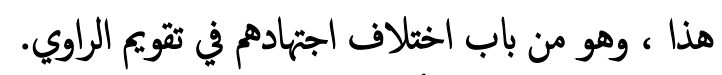

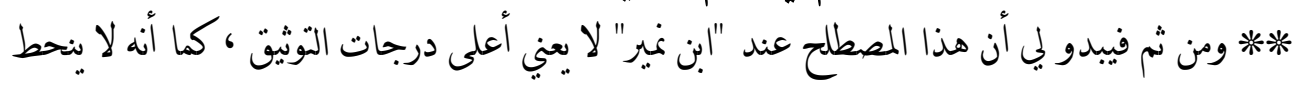

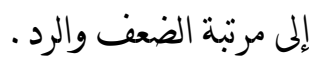

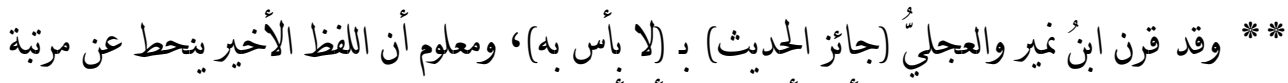

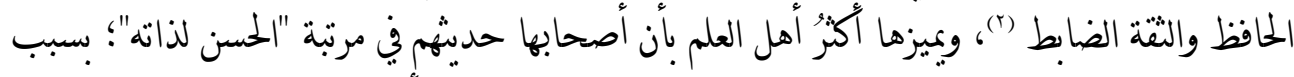

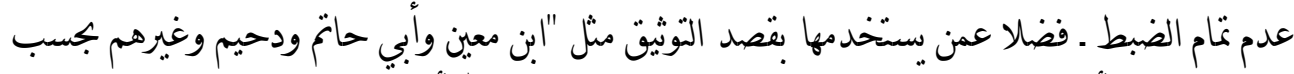
السياق". وهي أعلى من يكتب حدئهم في المتابعات والشواهد، والهُ أعلم.

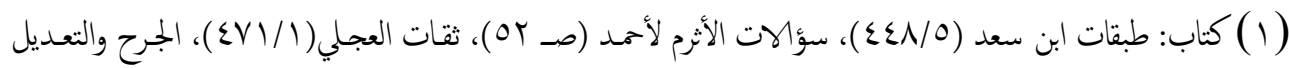

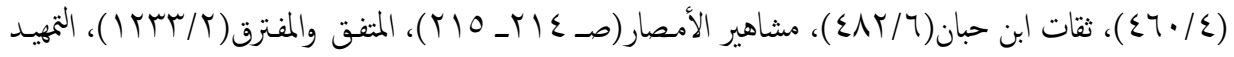

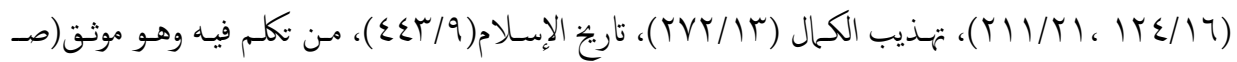

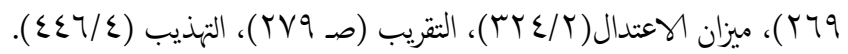

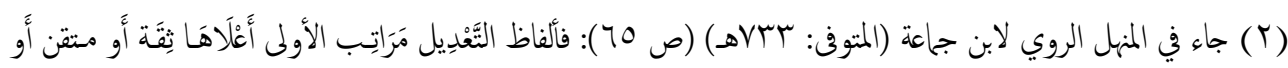

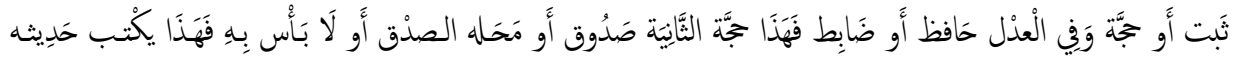

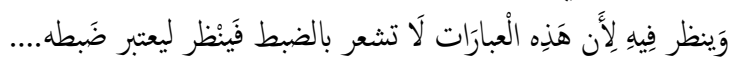




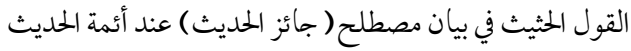

** وعليه . . فكلام الإمامبن لا شك أدنى كمن صرح بتوثيقه وإنقانه، وكذا أرفع من لينه كأبي زرعة وابن

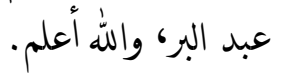

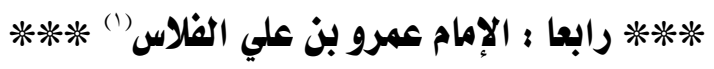

** * لم أقف لله إلا على موضع و احد *

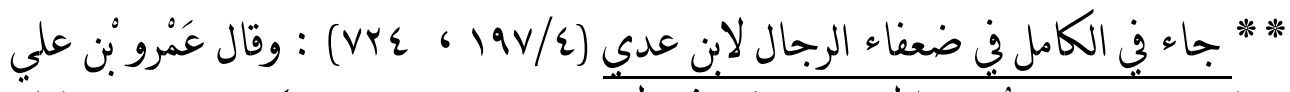

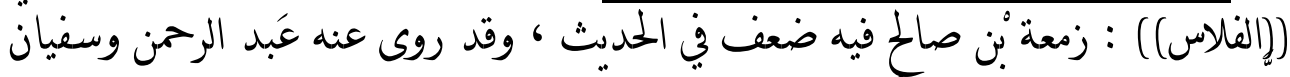

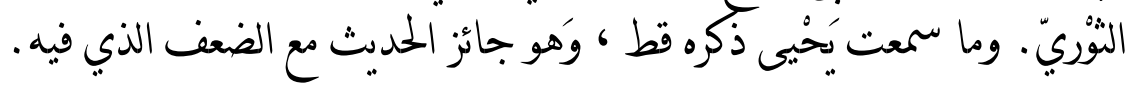

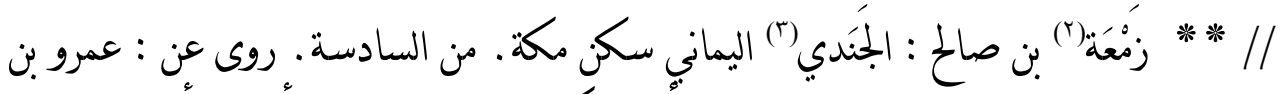

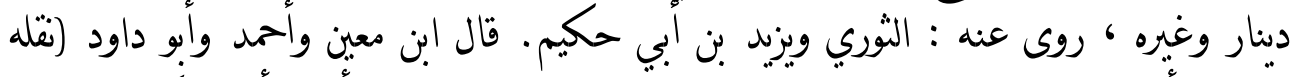

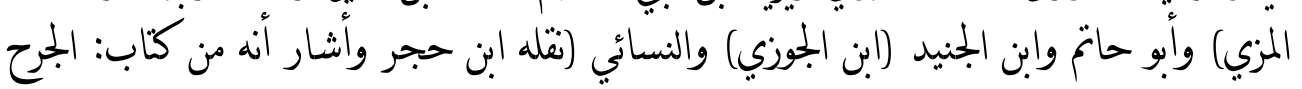

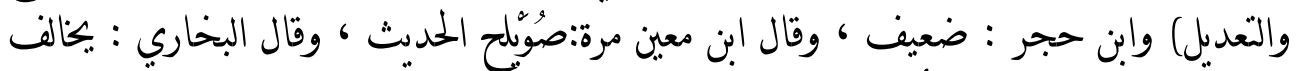

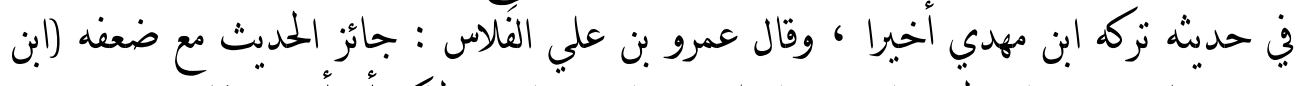

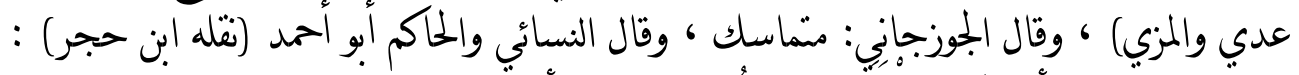

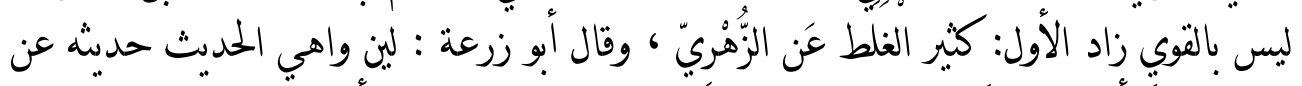

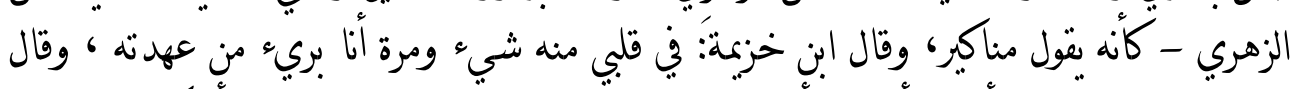

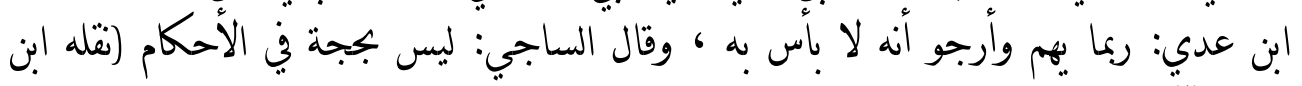

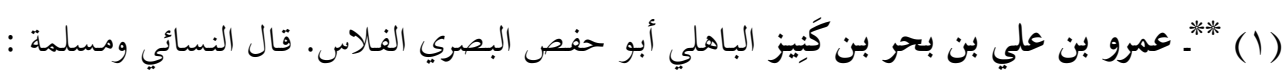

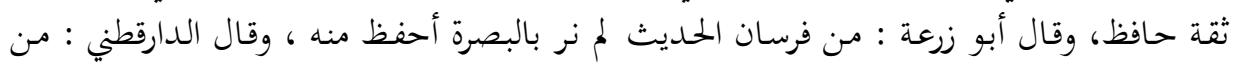

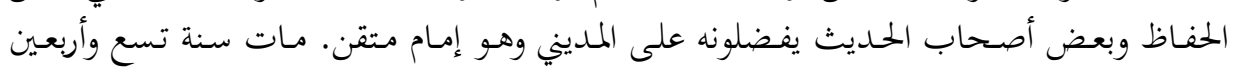

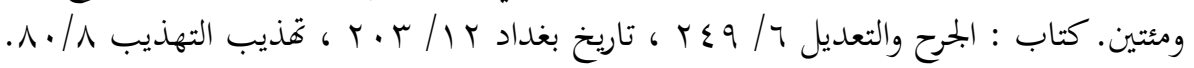

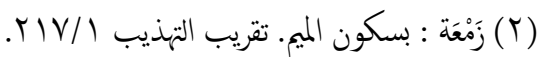

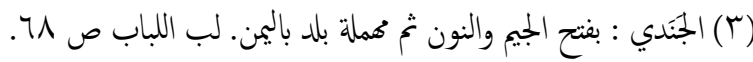

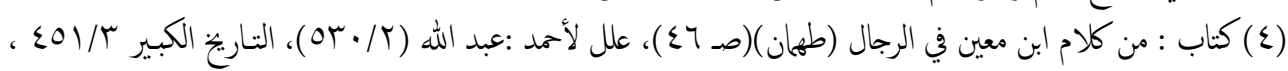

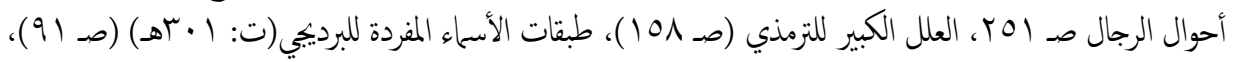

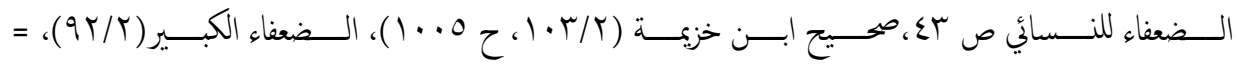


** قلت : هو إلى الضعف أقرب ـ كيّر المناكير عن الزهري ؛ كا قال النسائي وأبو زرعة

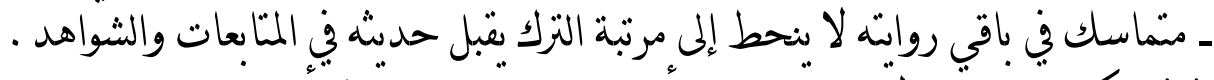

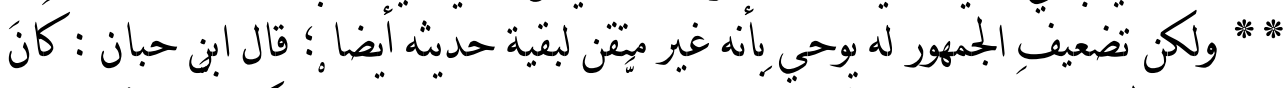

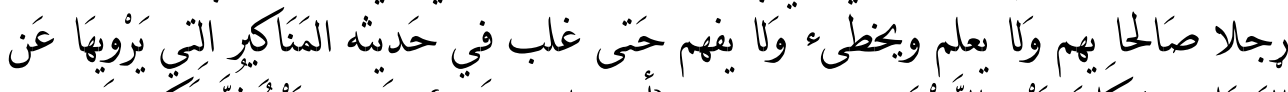

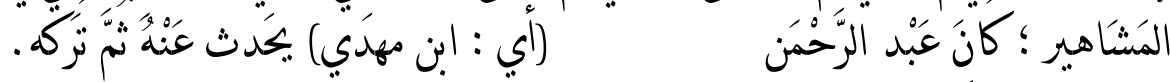

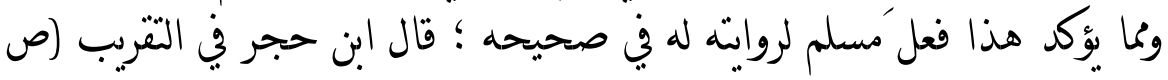

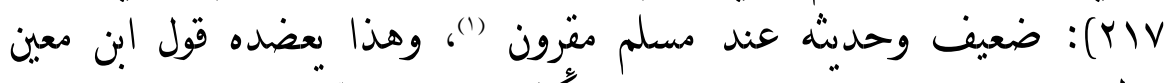

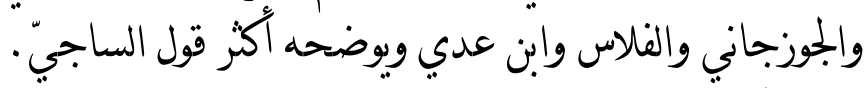

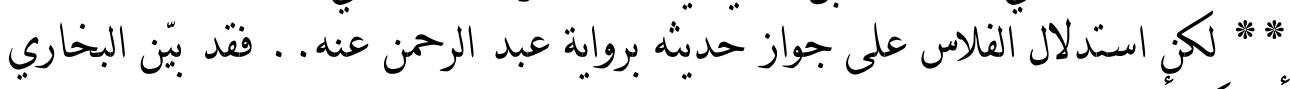

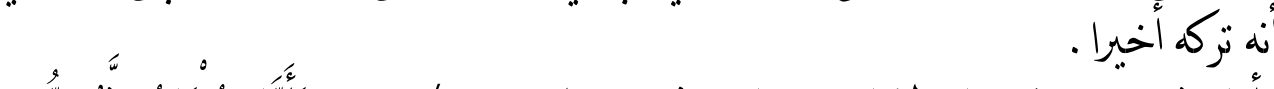

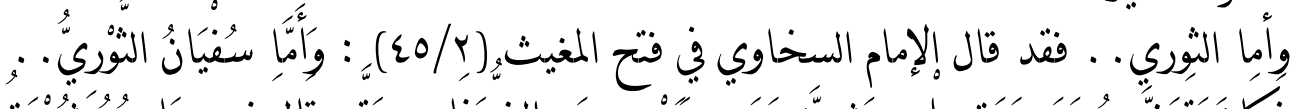

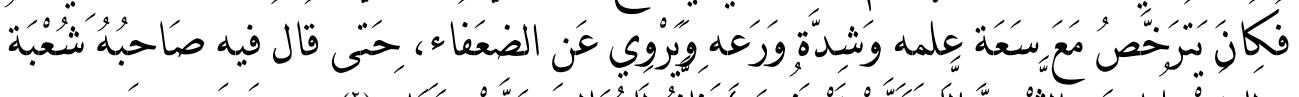

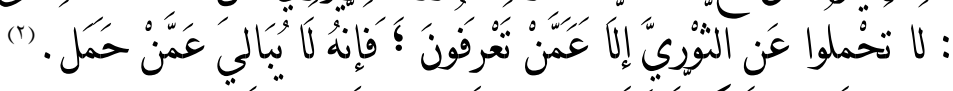

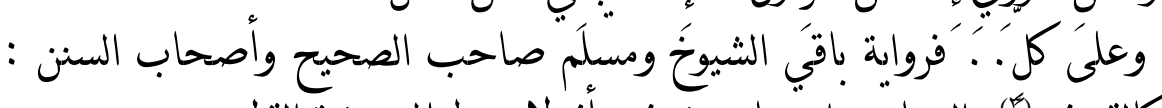

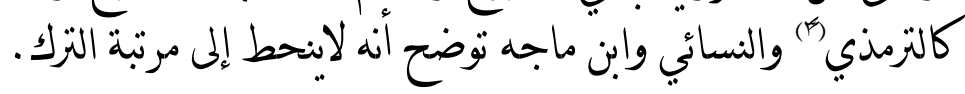

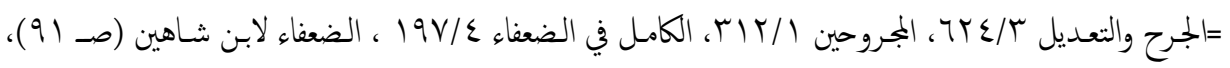

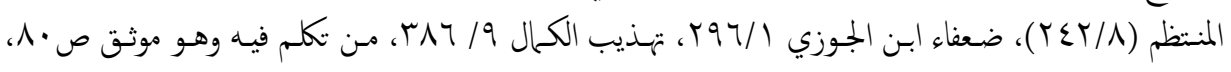

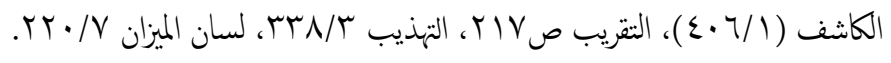

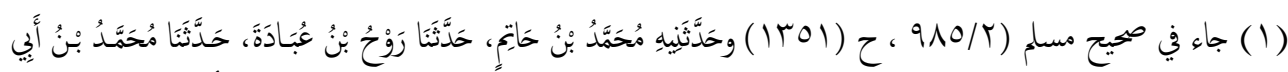

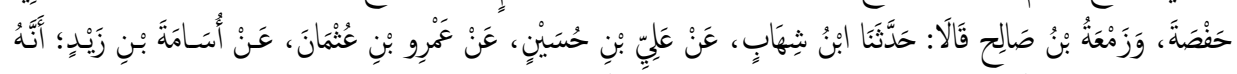

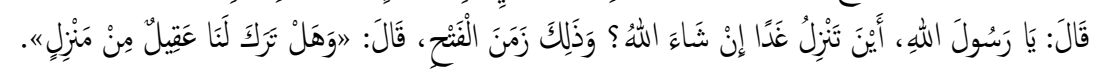

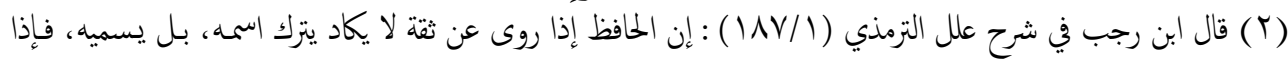

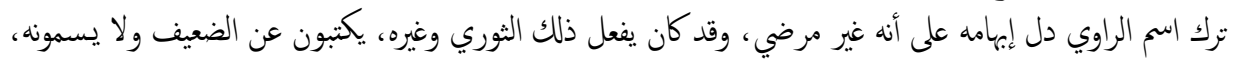

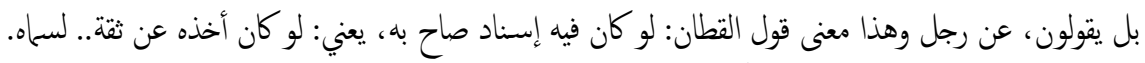

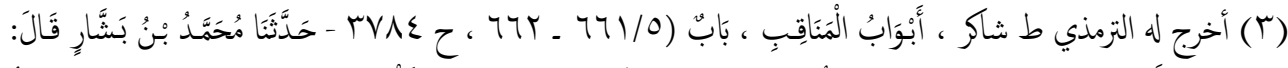

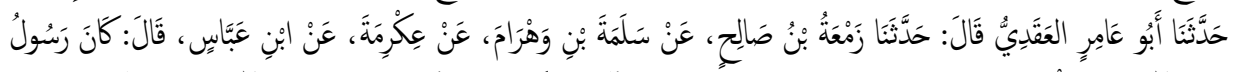
اللَهِ

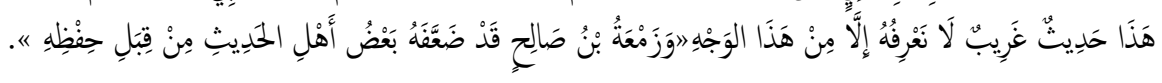




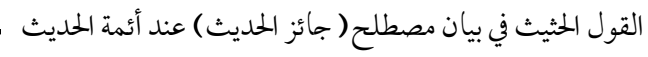

ـ * * قلت : ومما سبق نببن أن كلام الإمام "الفلاس" واضح لا لبس فيه ، وهذا المصطلح

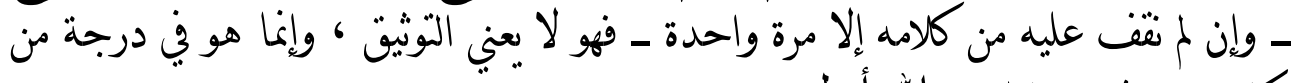

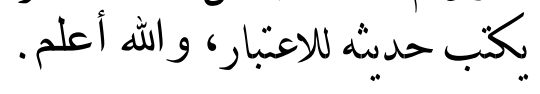

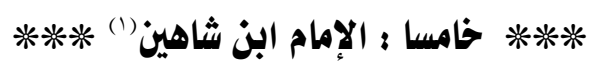

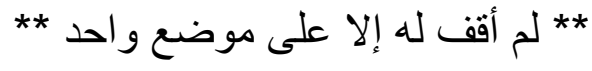

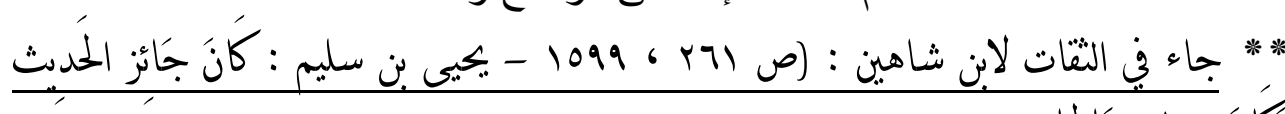

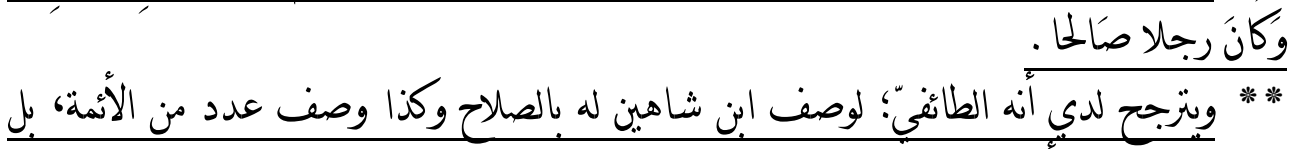

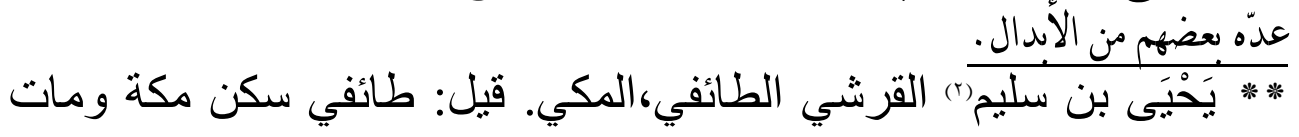

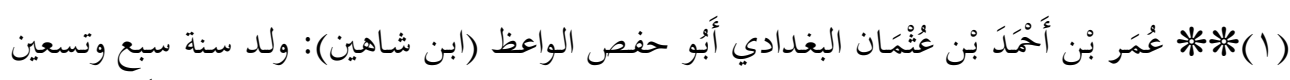

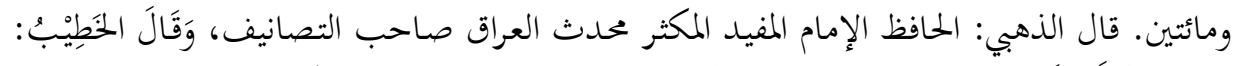

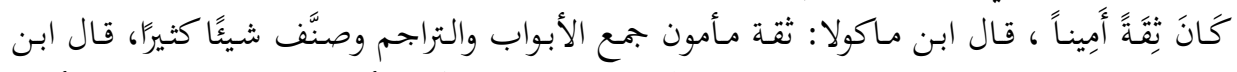

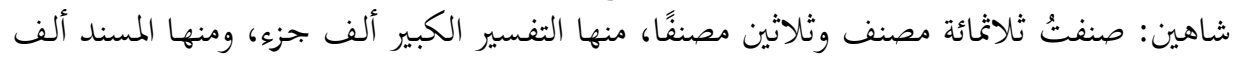

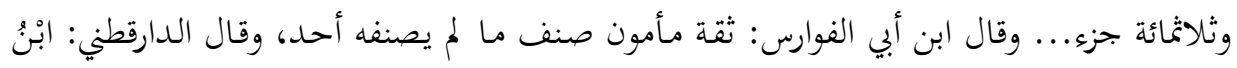

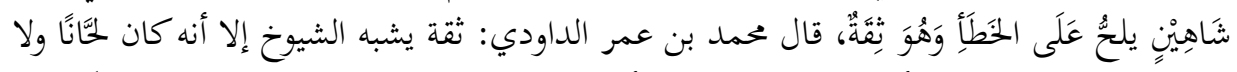

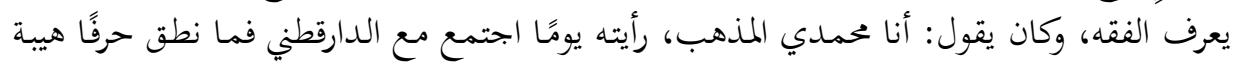

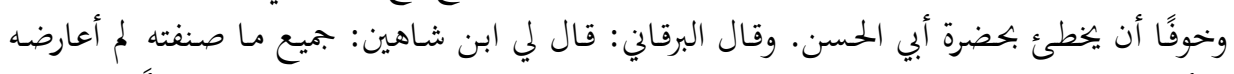

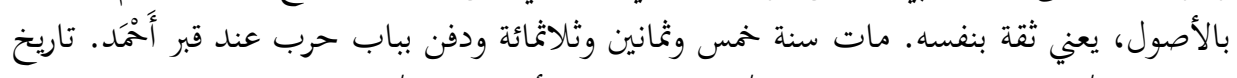

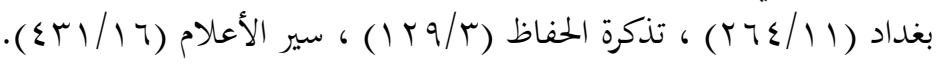

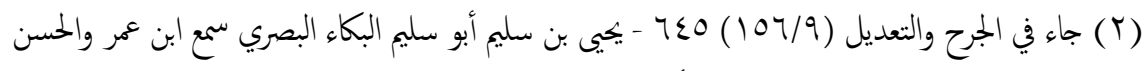

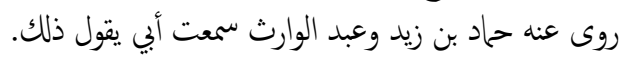

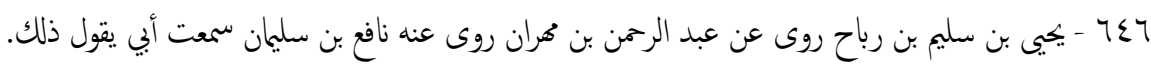
VV

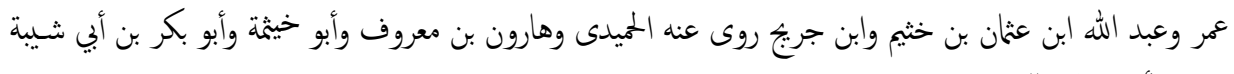
سمعت أبي يقول ذلك أ...

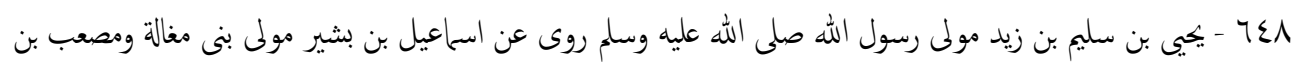

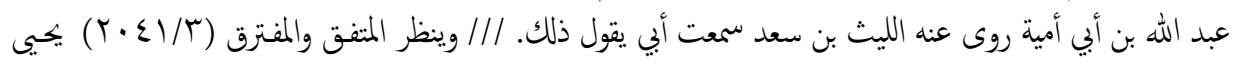

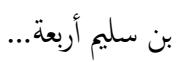

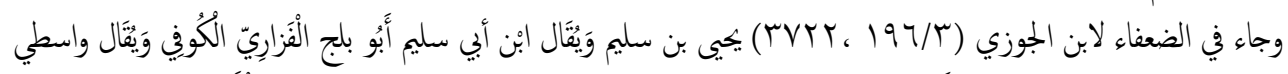

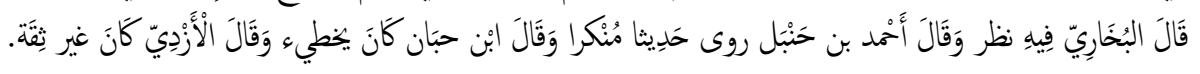



القول الحثيث في بيان مصطلح ( جائز الحديث) عند أئمة الحديث

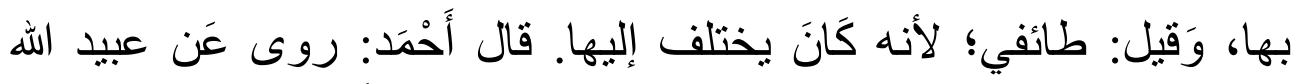

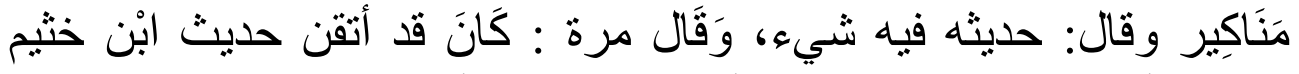

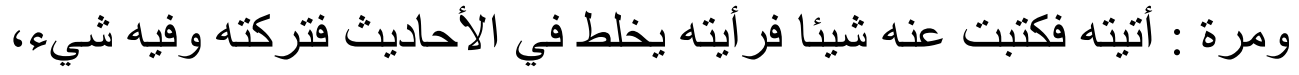

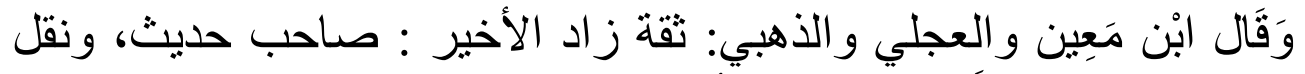

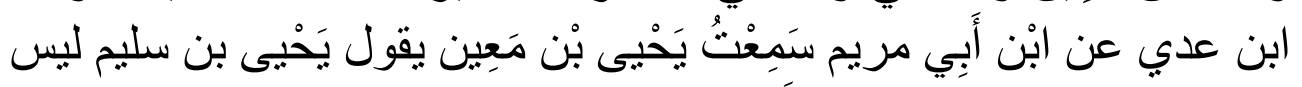

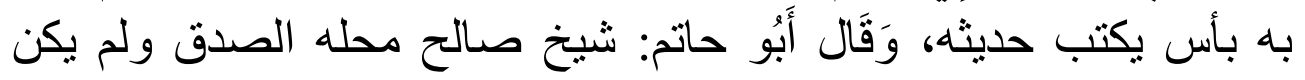

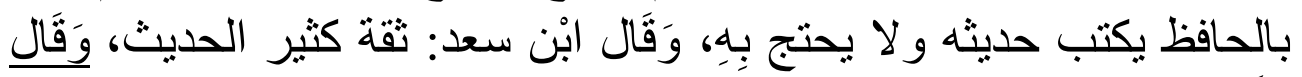

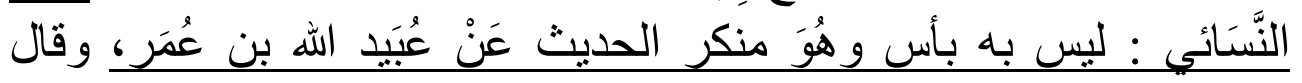

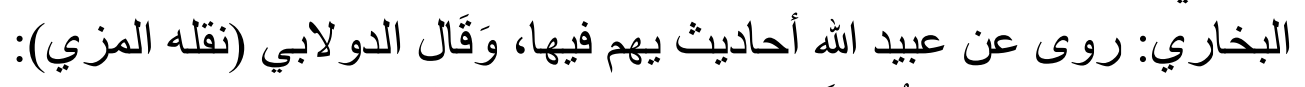

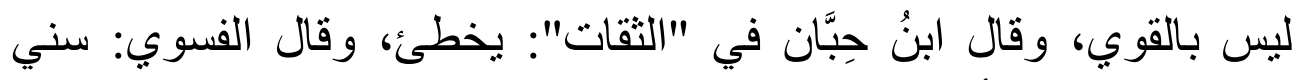

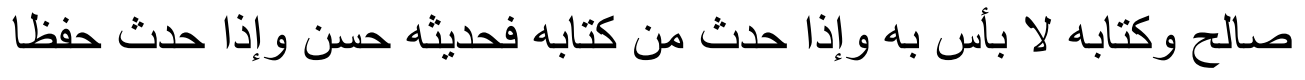

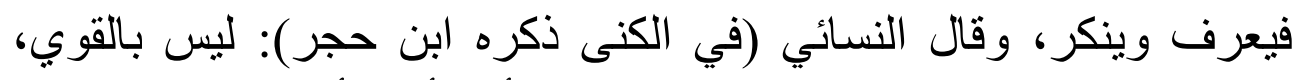

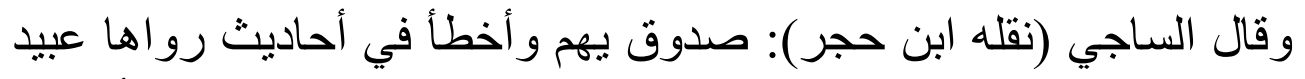

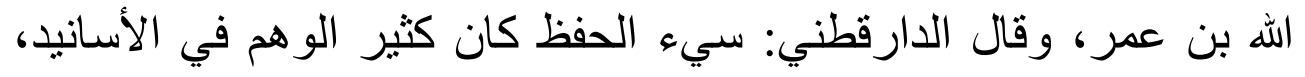

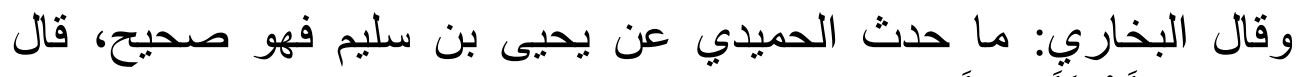

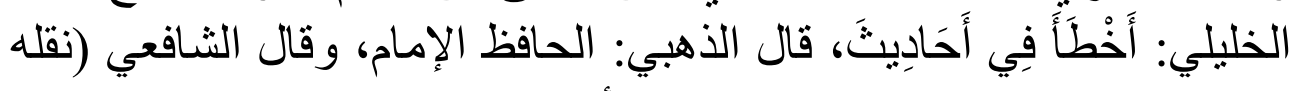

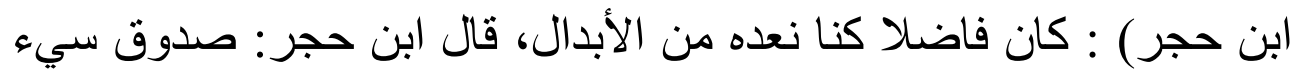

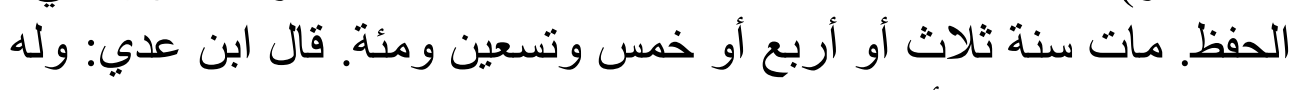

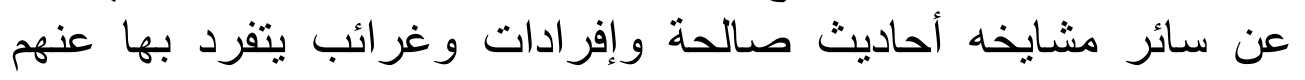

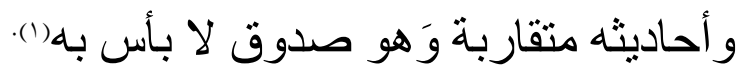

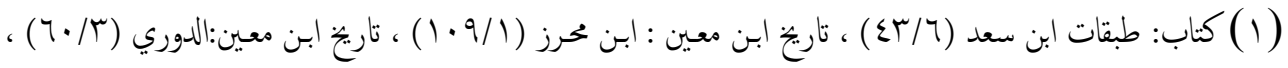

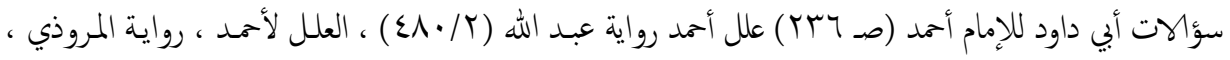

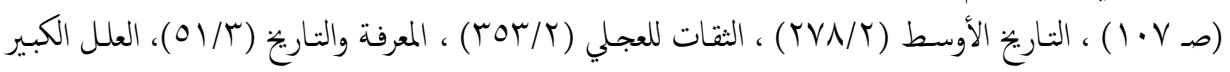

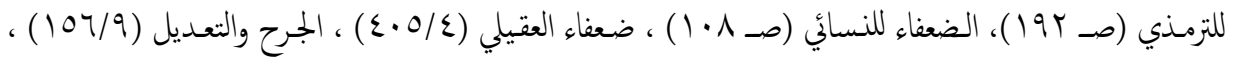

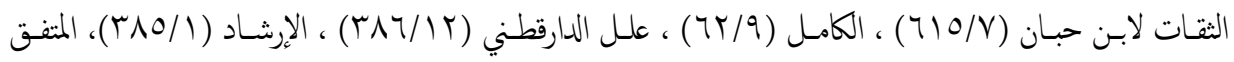

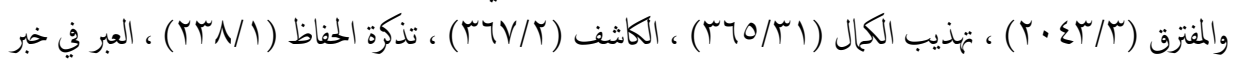

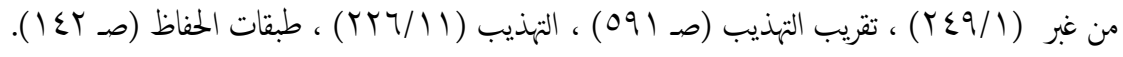




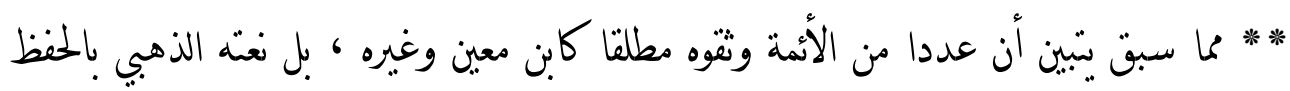

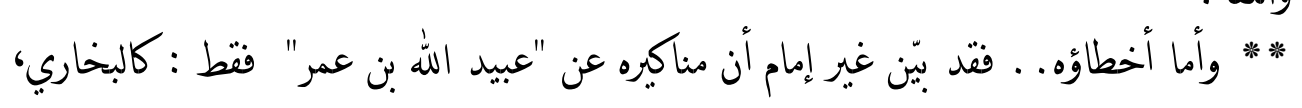

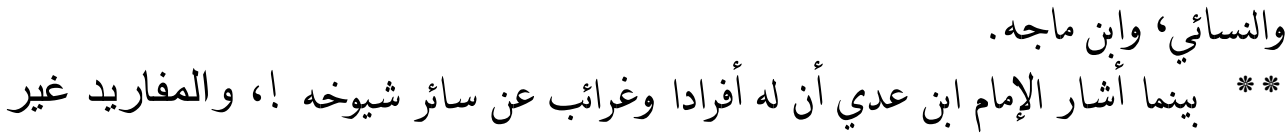

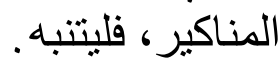

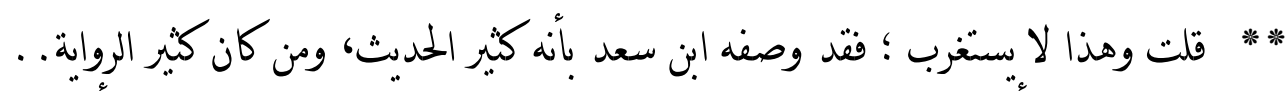

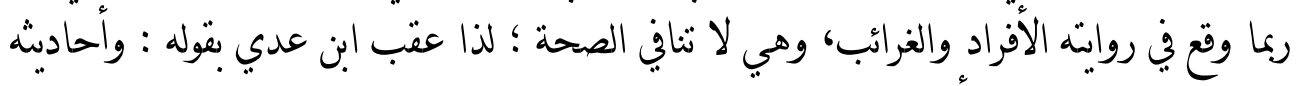

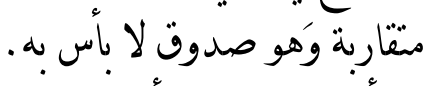

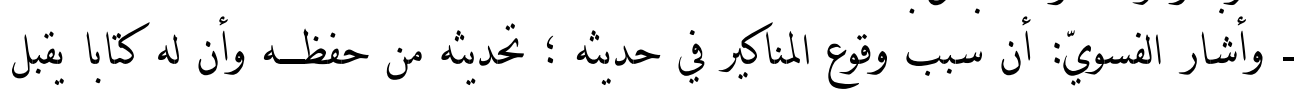

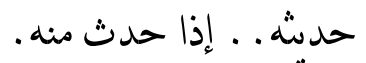
ـ وأثشار البخاريّ إلى أن الحميدي" صحيح الحديث عنه مطلقا كما أشار أحمد أنه "كان قد أثنى

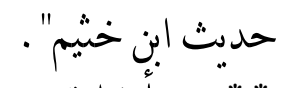

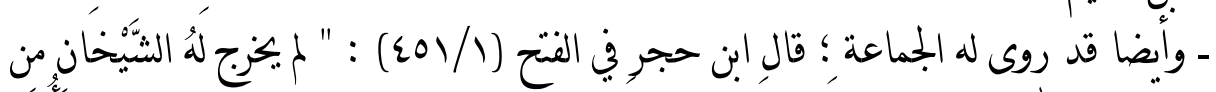

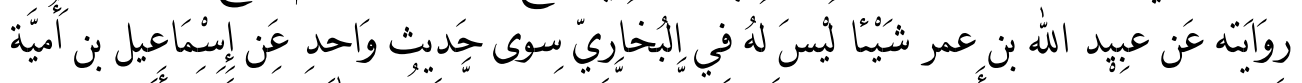

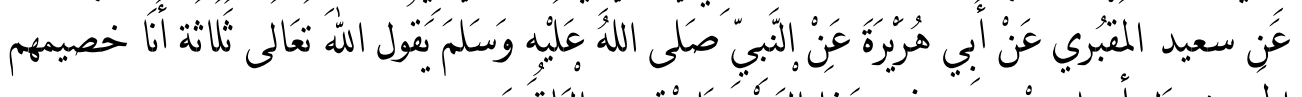

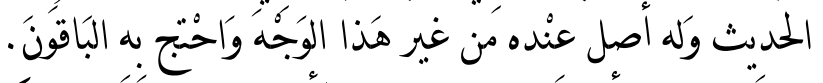

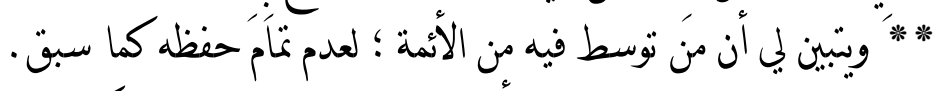

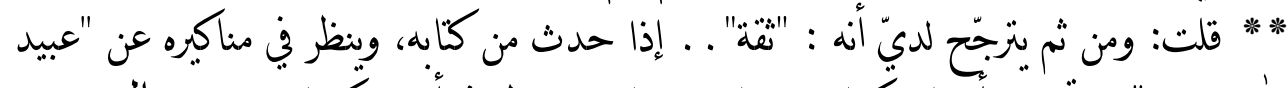

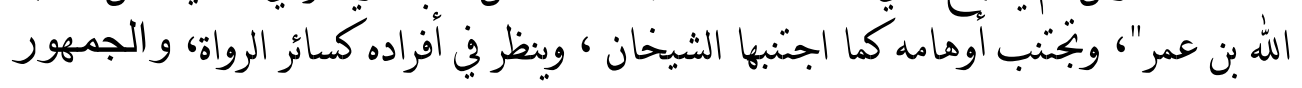
على قبو لها كما سبق.

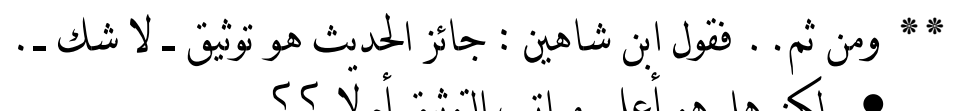

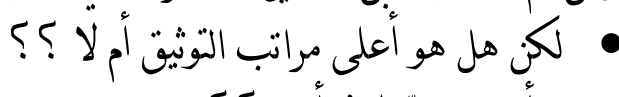

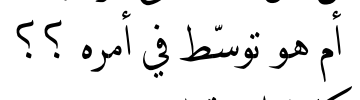

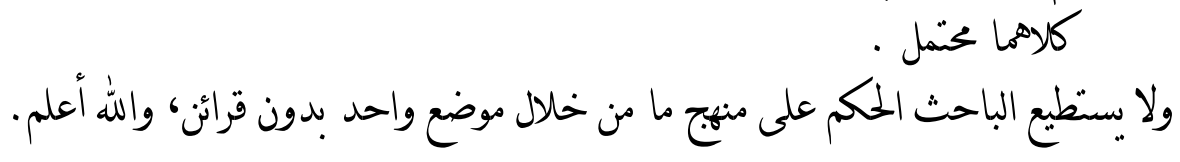


=

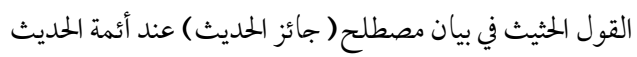




\section{الخاتقة}

الحمد لله الذي بنعمنه تنم الصالحات ، وبتوفيقه تسنبط دقيق المسائل

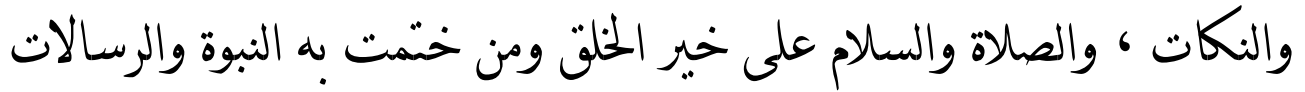

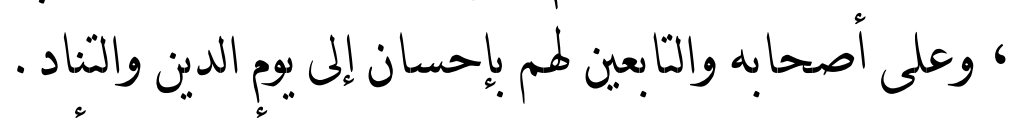

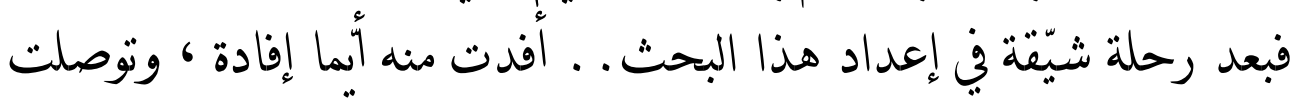

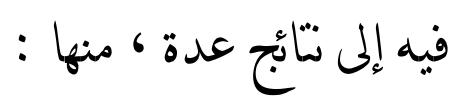

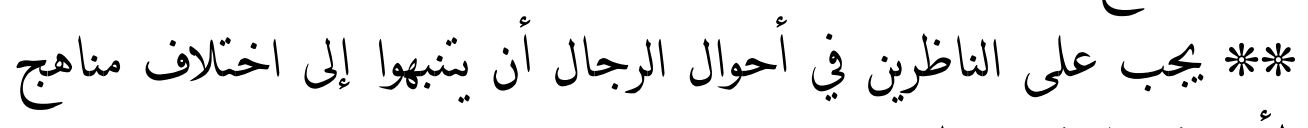
الأئمة في إطلاق مصطلحاتهم.

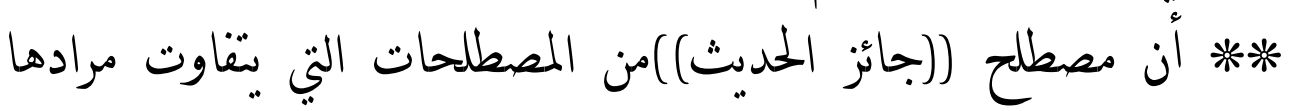

$$
\begin{aligned}
& \text { بكسب الإمام الذي ستخدمه ، }
\end{aligned}
$$

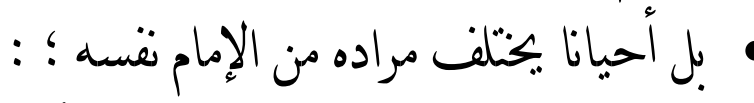

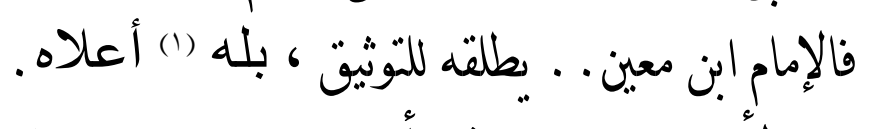

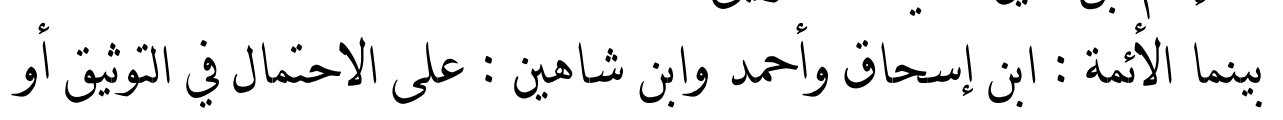

وأيضا ستخدمه الإمام الذهبيّ فيمن يتوسّط في أمرهم ، ولديه موضع بحتمل

الدّويق •

والإمام العجلي : يقّاوت استخدامه له ما بين : توثيق ، أو توسط ، أو

$$
\text { تضعيف مع قبوله في الاعتبار . }
$$

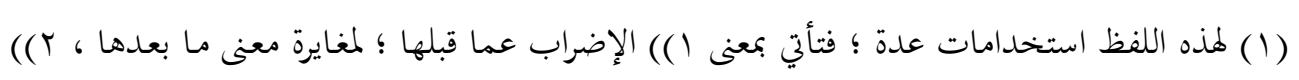

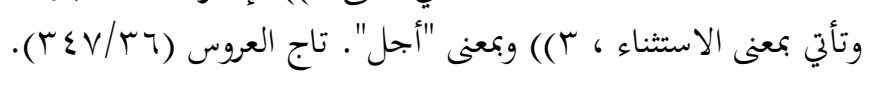




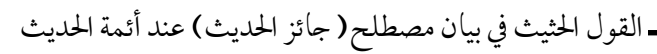

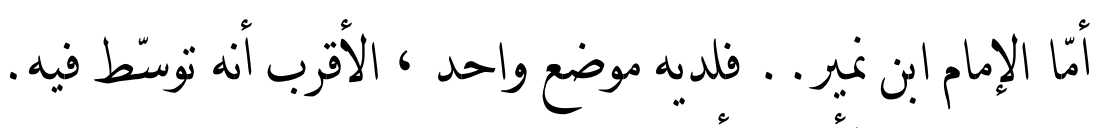

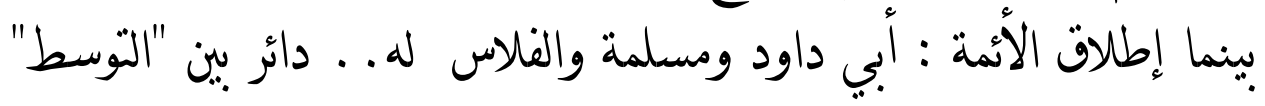

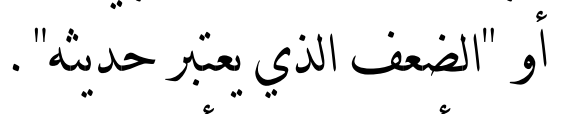

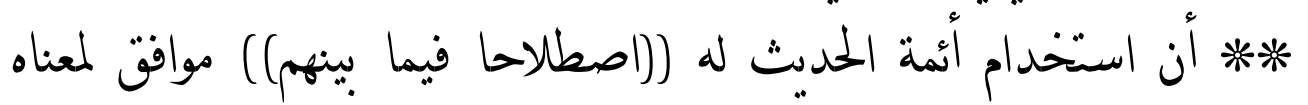

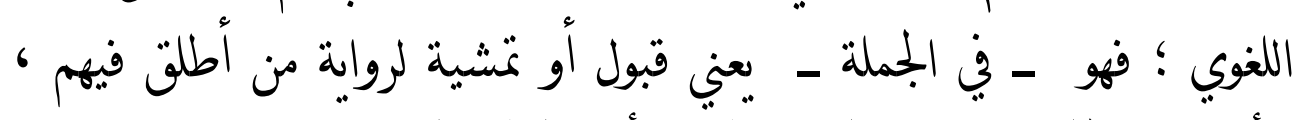
و أحبانا بطلق بمعنى الخيرية و الأفضلبة (التوثيق). تُ أن النظر في القرائن من الأمور المساعدة على فهم مراد الأئمة من إطلاق - مصen الأق

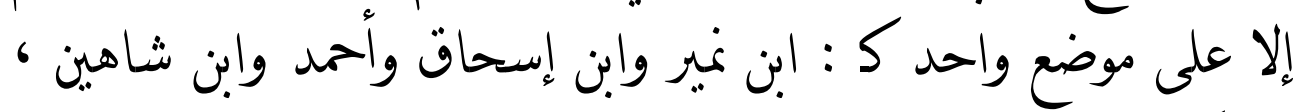

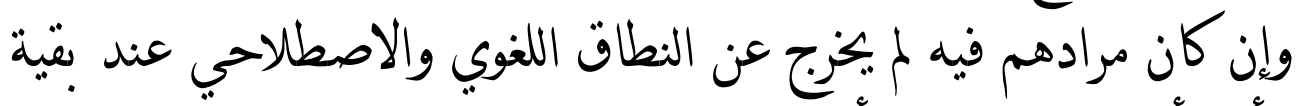

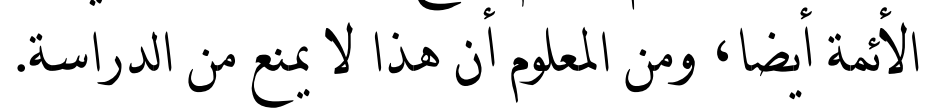

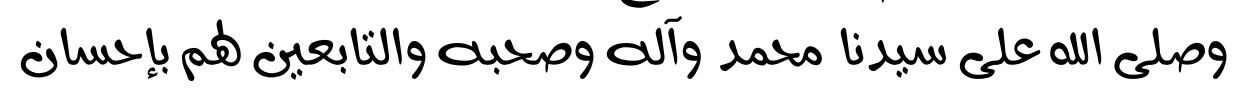
وسلم تنسلبما كنبرا .

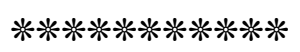




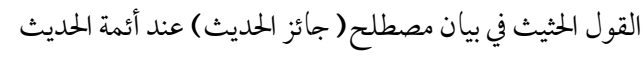

\section{ثبت المصادر والمراجع}

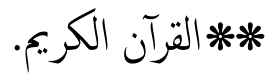

**إيحاف الخيرة المهرة بزوائد المسانيد العشرة، لأمد بن أبي بكر بن إساعيل بن سليم بن قايماز

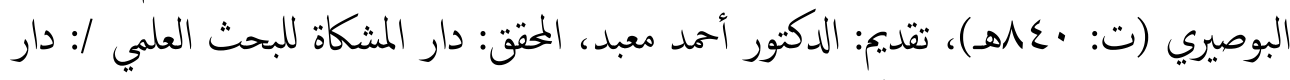

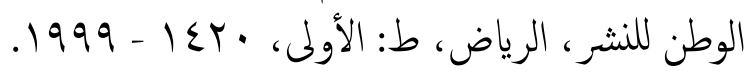

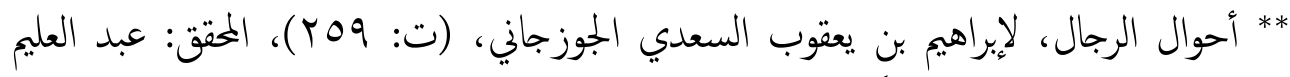

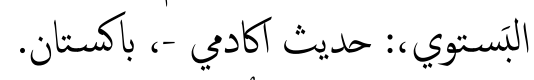

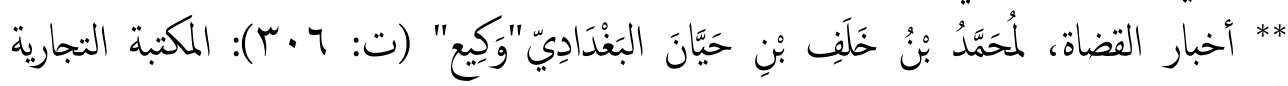

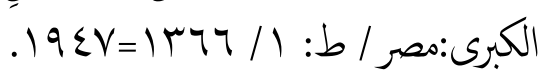

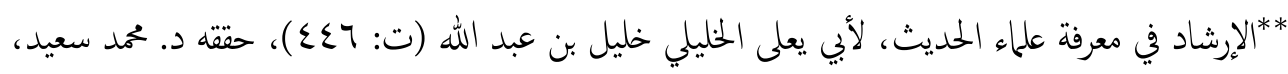

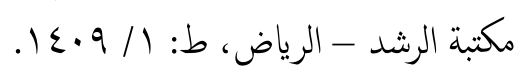
** الآحاد والمثاني، لأبي بكر بن أبي عاصم الشيباني (ت: (TNV)، حقته د. باسم فيصل: دار الراية

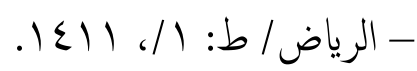

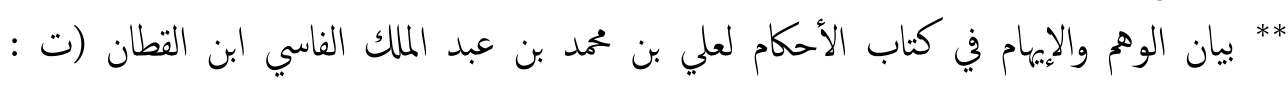

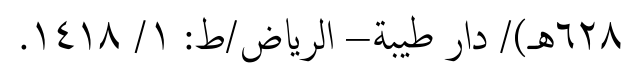

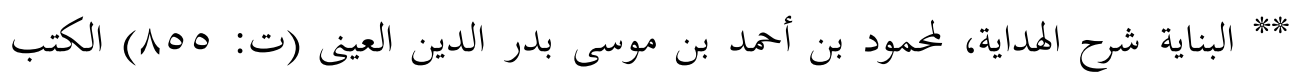

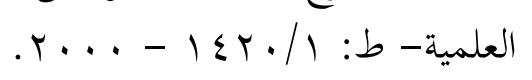

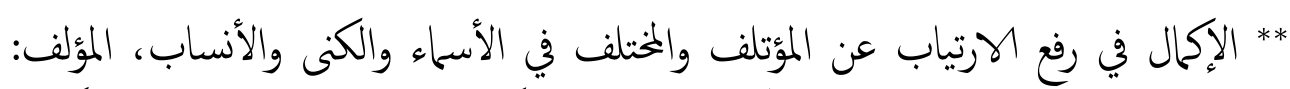

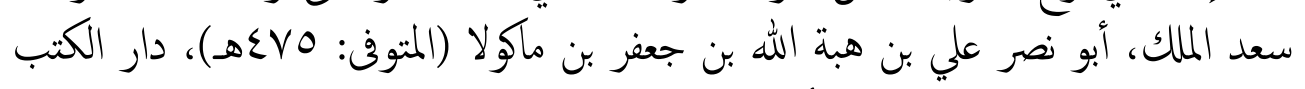

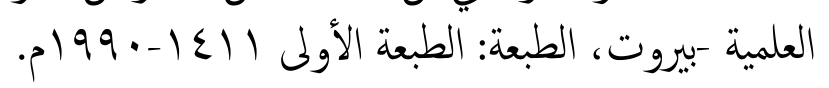

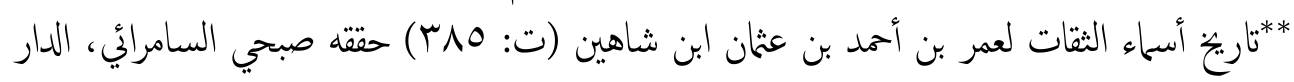

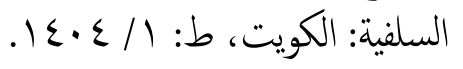

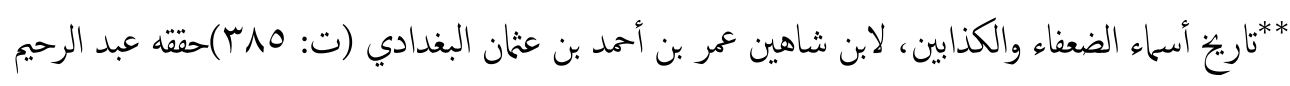

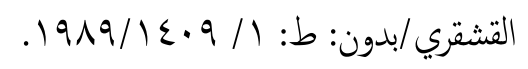

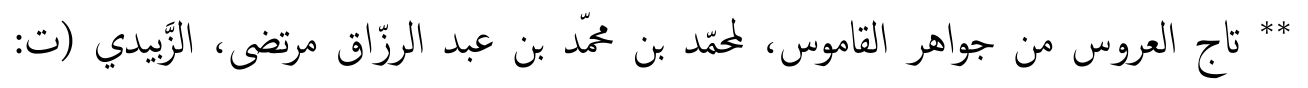

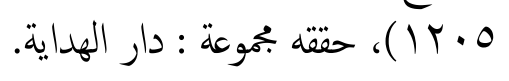
** تاريخ ابن معين (رواية عثان الداري)، الحقق: د. أحمد محمد نور سيف/ دار المأمون للتزاث - دمشق. 


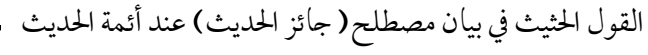

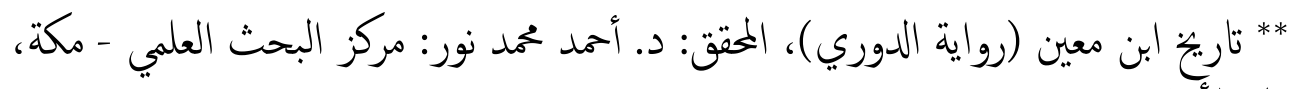
ط: الأولى،

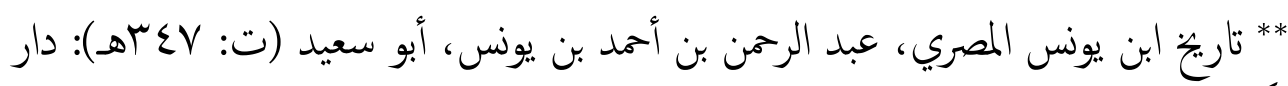

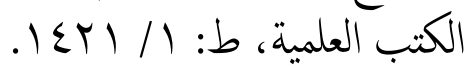

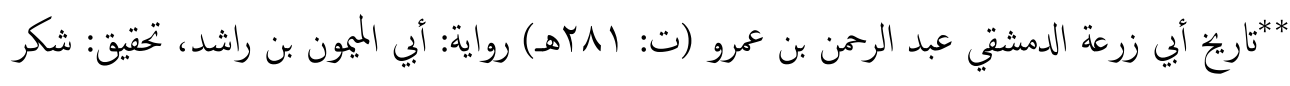

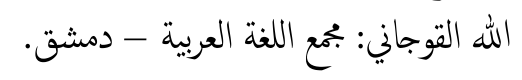

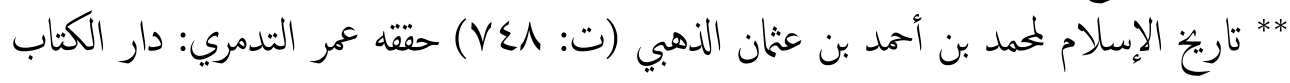

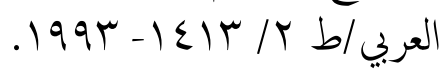

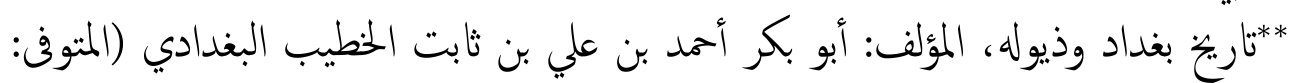

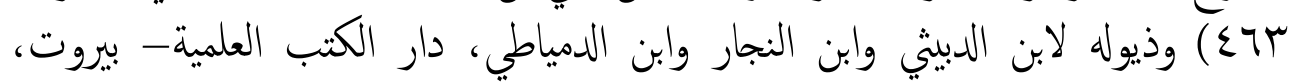

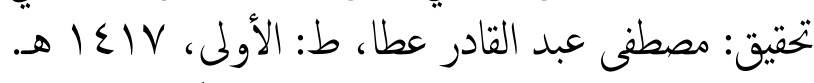

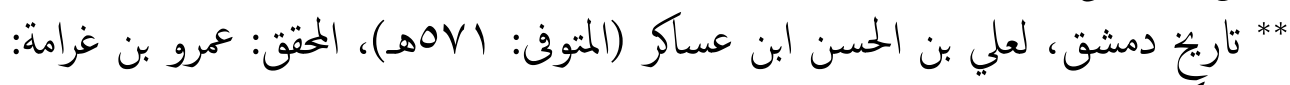

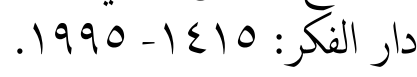

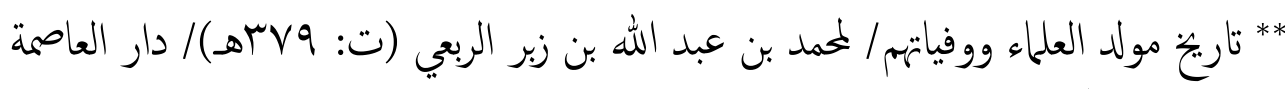

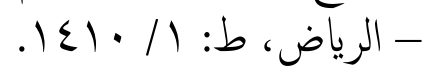

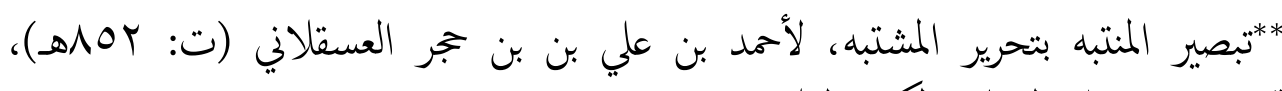
تحقيق: محمد علي النجار: المكنبة العلمية.

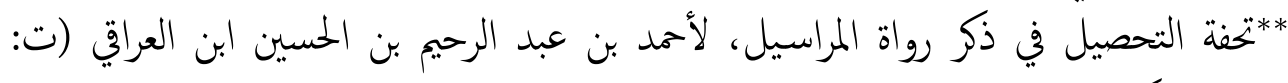
ك

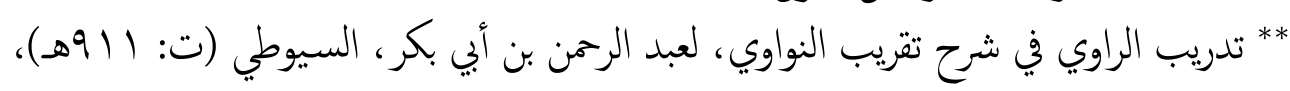

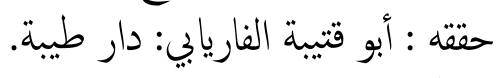

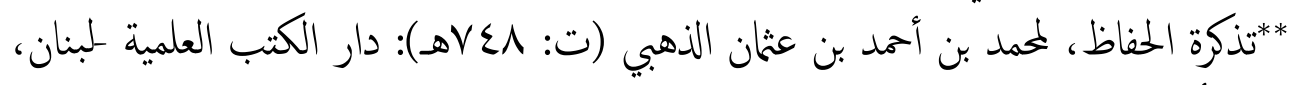

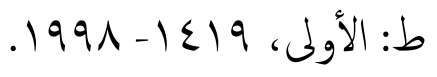

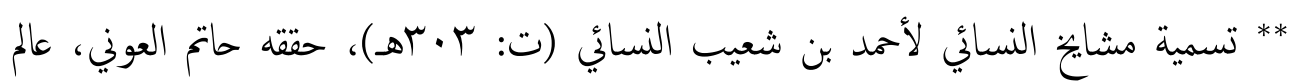

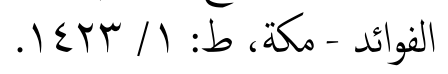

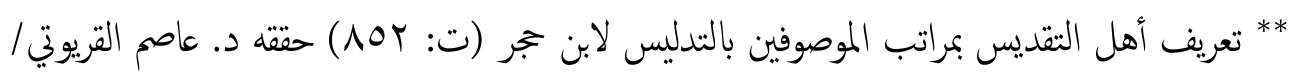

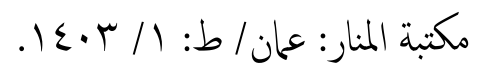




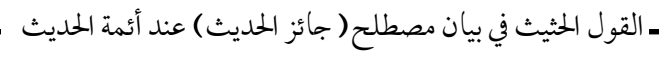

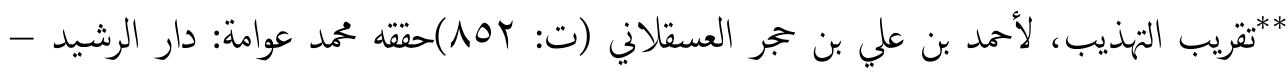

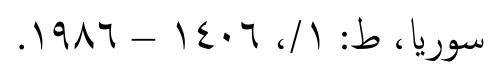

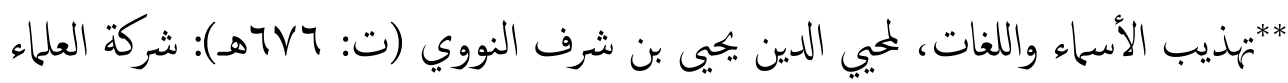
بمساعدة إدارة الطباعة المنيرية.

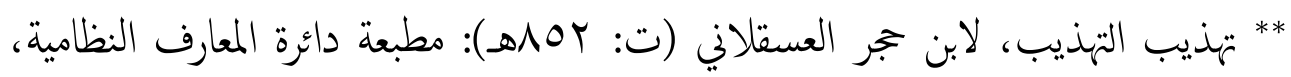

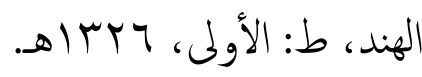

** تهذيب اللغة، لمحمد بن أحمد بن الأزهري الهروي (ت: · • (YV) حققه محمد عوض: دار إحياء التراث

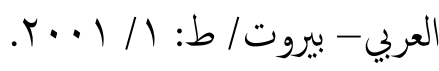

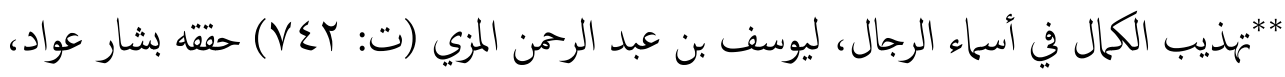

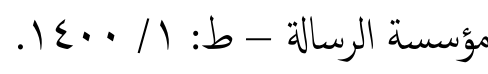

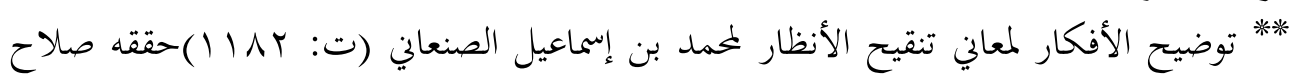

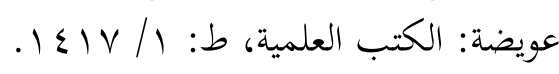

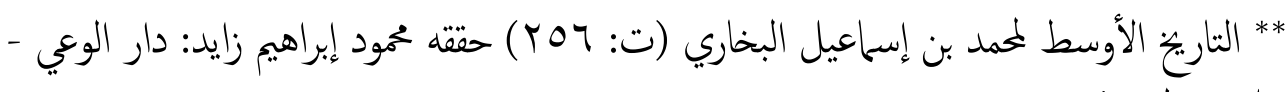

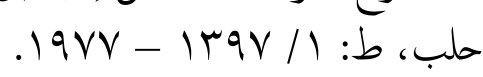

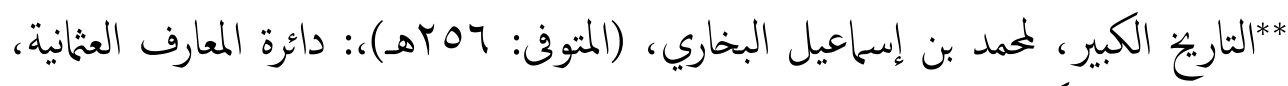

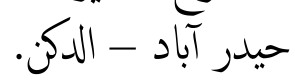

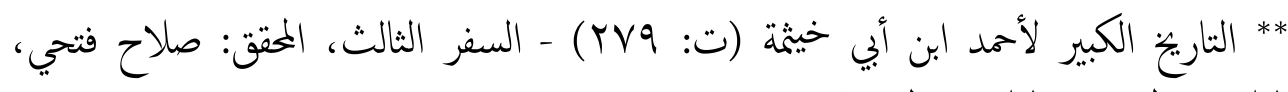

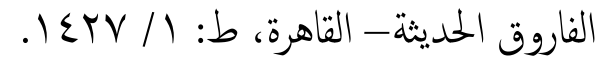

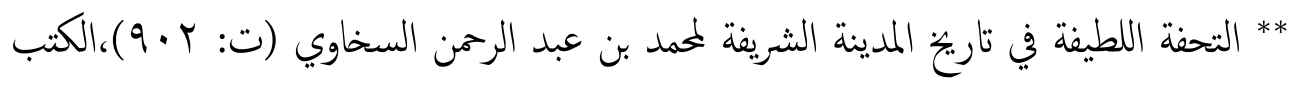
العلميه، ط: 1: 199\%/

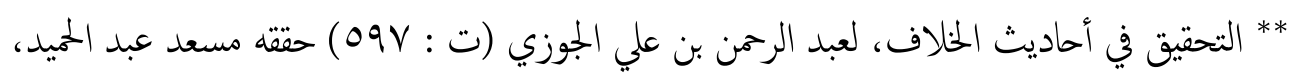

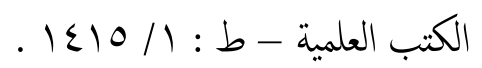
** التعديل والتجريح لمن خرج له البخاري في الجامع الصحيح لسليمان بن خلف الباجي(ت: عVع):

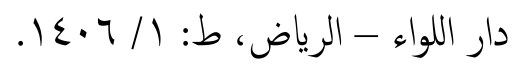

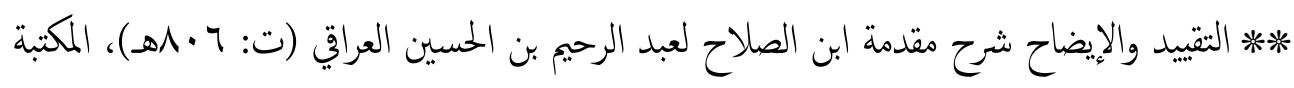

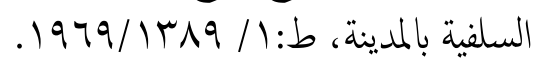

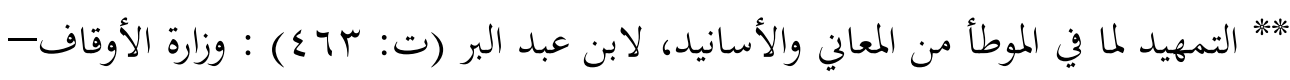

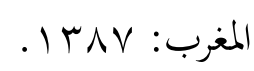

\section{$1 \cdot 49$}




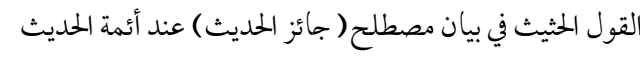

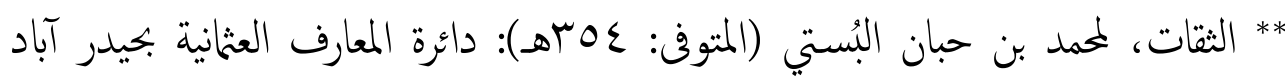

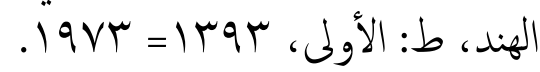

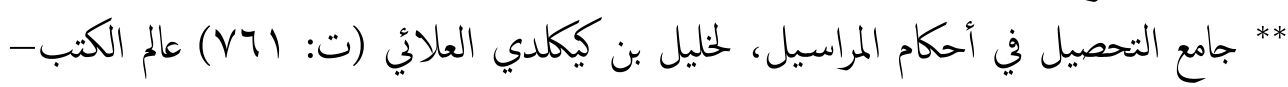
بيروت، ط: ** الجامع المسند الصحيح = صحيح البخاري محمد بن إسهاعيل البخاري،: دار طوق النجاة،

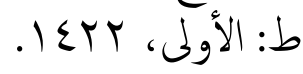

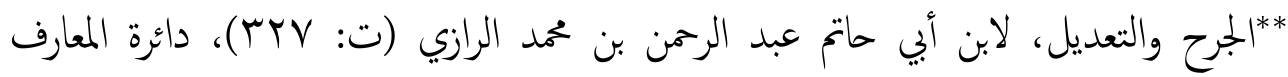

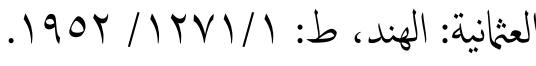

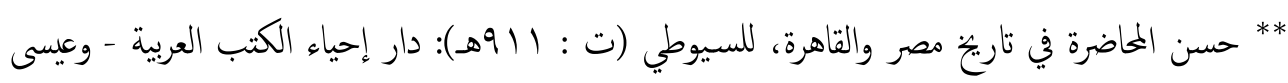

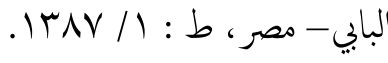

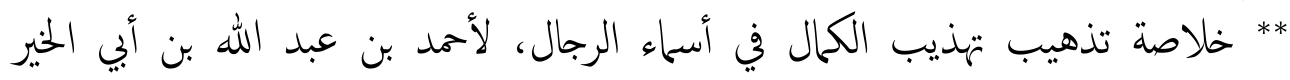

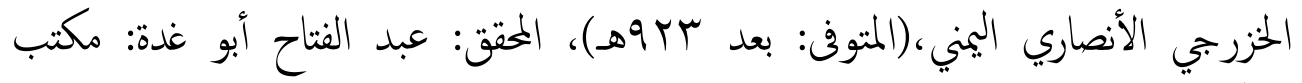

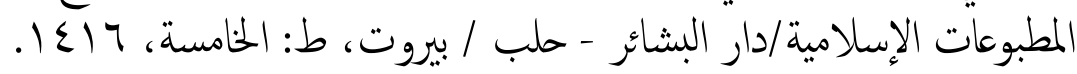

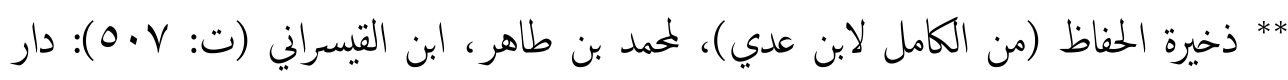

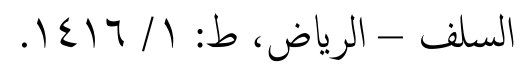

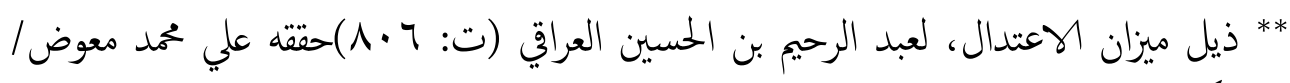

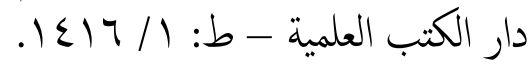

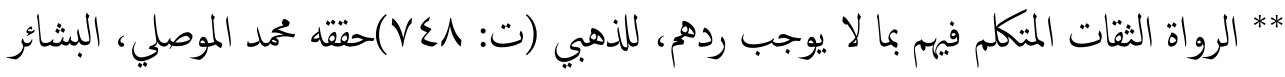

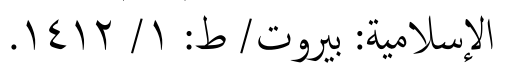

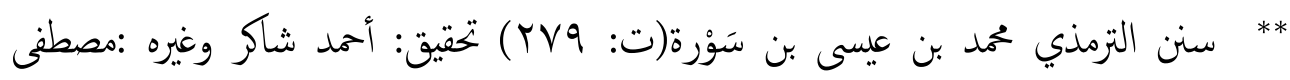

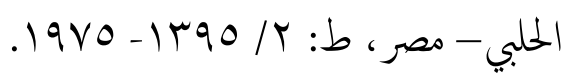

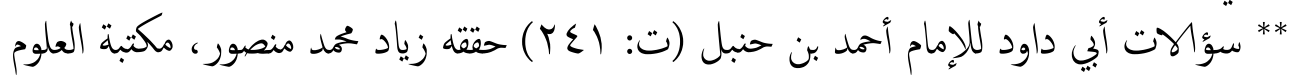

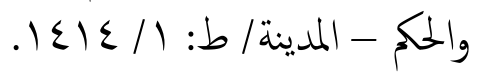

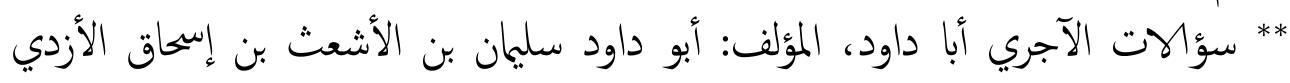

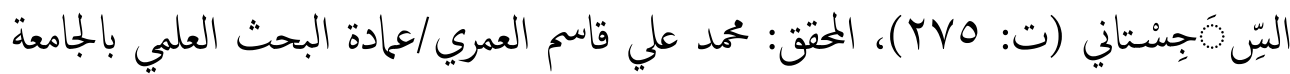

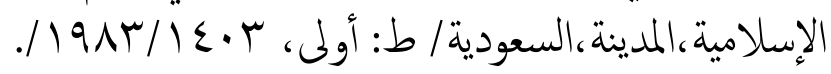

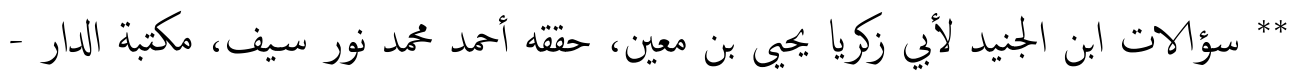

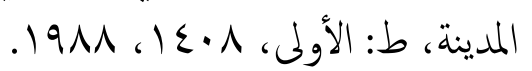




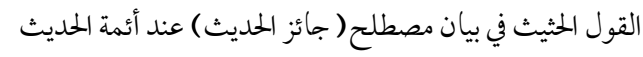

* *ؤالات محد بن عثمان بن أبي شيبة لعلي بن المديني(ت: ع (Y)، حققه موفق عبد الله، مكتبة

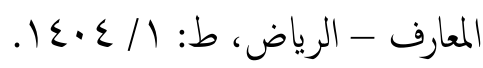

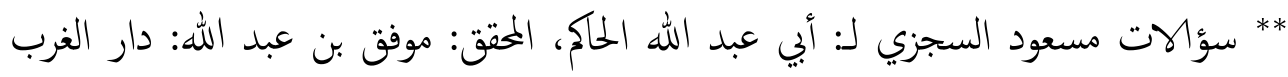

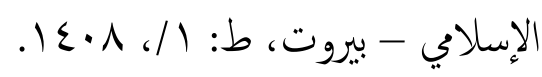

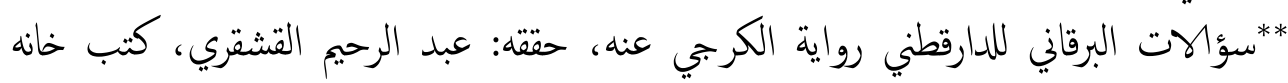

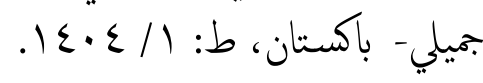

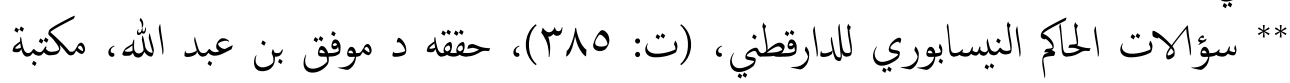

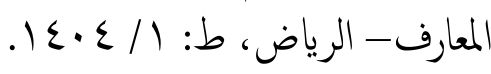

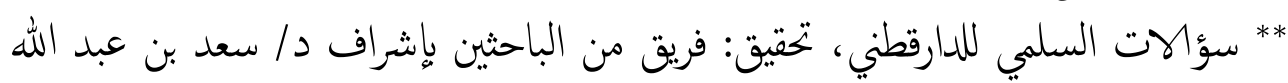

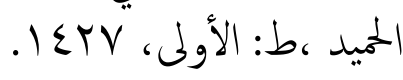

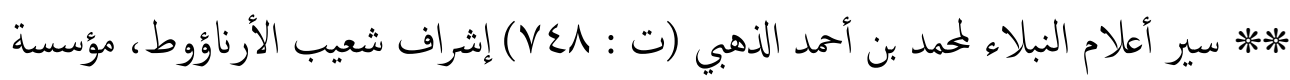

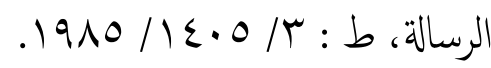

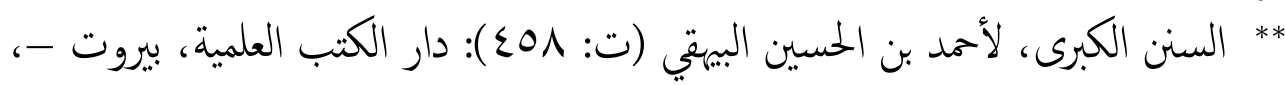

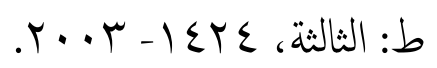

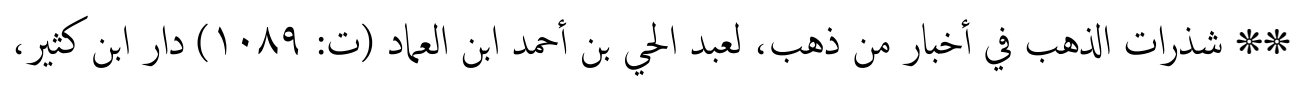

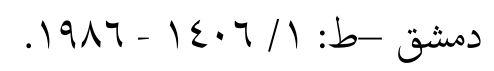

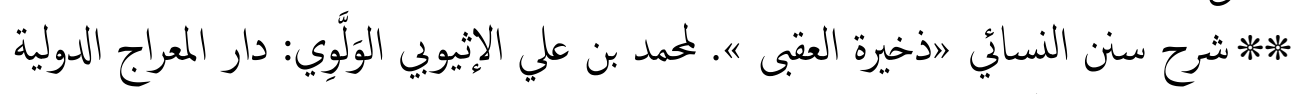

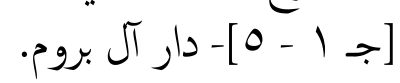

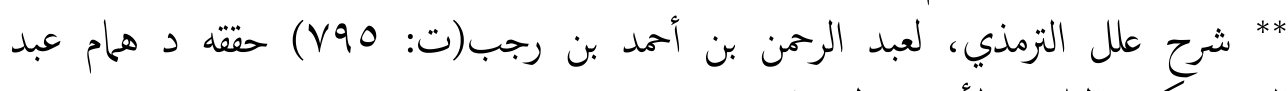

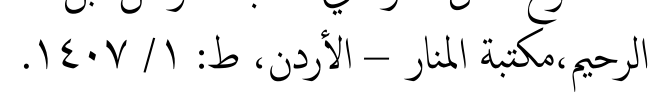

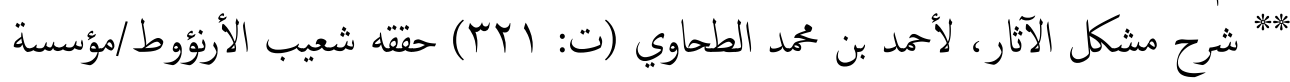

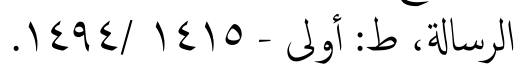

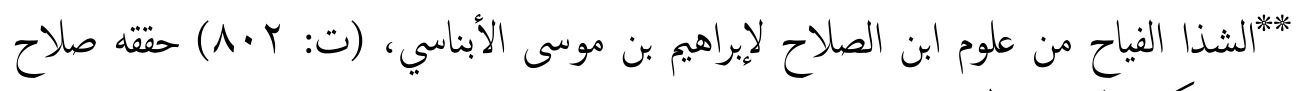

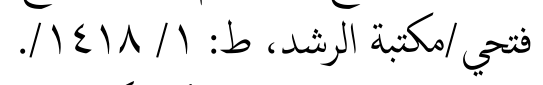

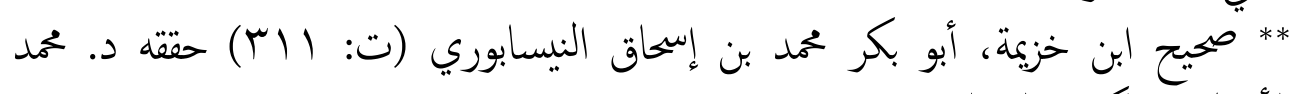

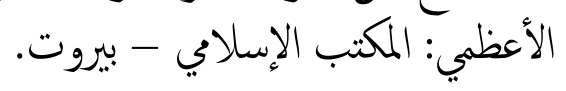

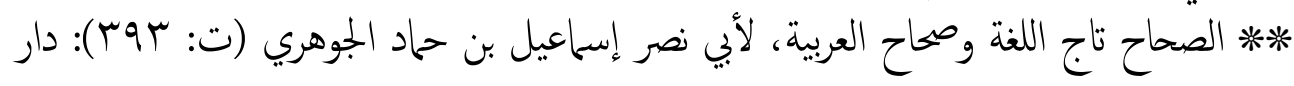

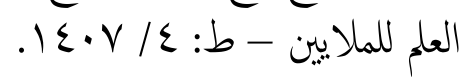




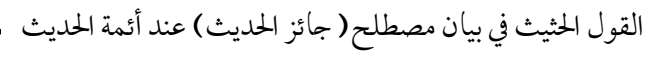

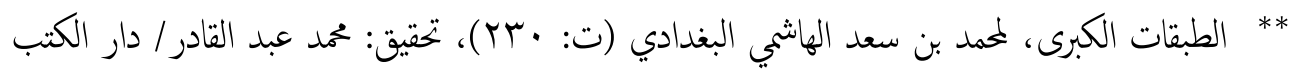

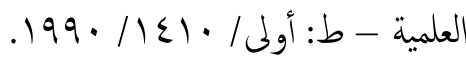

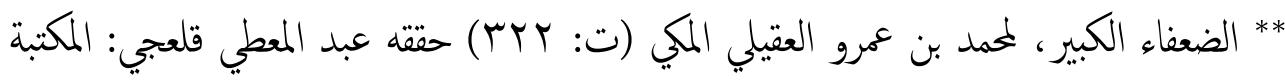
العلمية - الم:

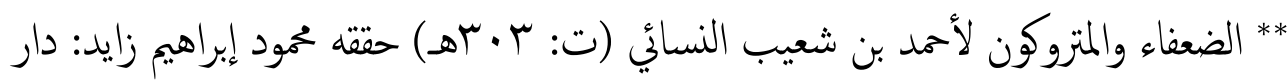

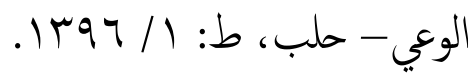
** الضعفاء والمتروكون ، لعبد الرحمن بن علي الجوزي (ت: ه9V)، المحقق: عبد الله القاضي :

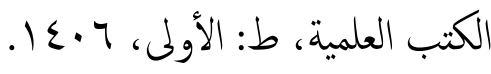

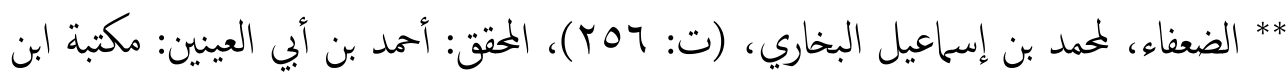
عباس، ط: / / / /

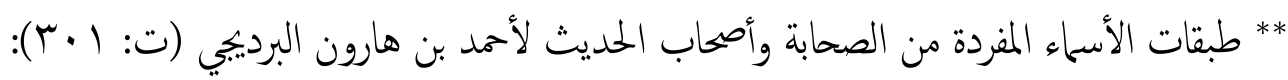
طلاس للدراسات، ط: 1911/

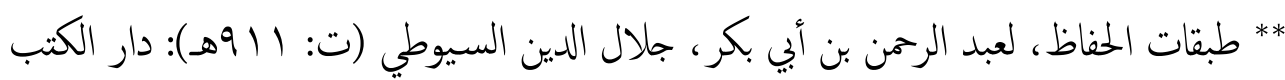

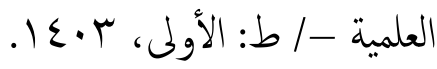

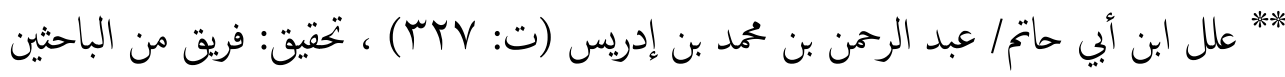

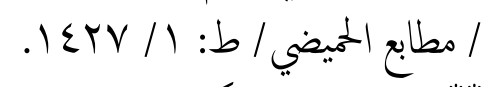

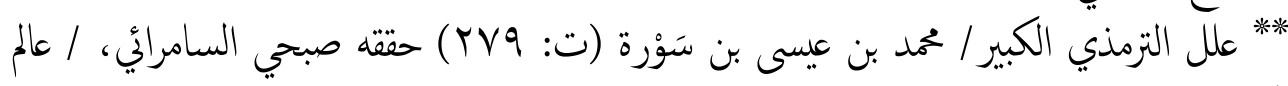

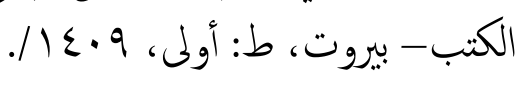

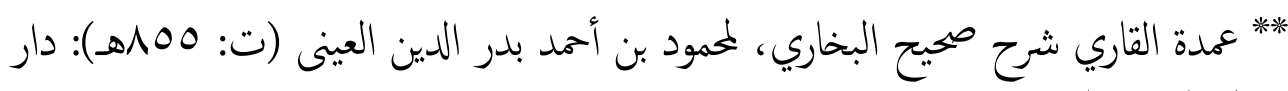
إحياء التراث العربي - بيروت.

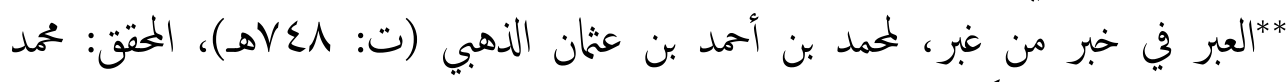
السعيد زغلول: دار الكتب العلمية. *** العلل الواردة في الأحاديث النبوية/ لعلي بن عمر الدارقطني (ت: مرآهـ)/ دار طيبة -

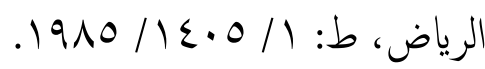

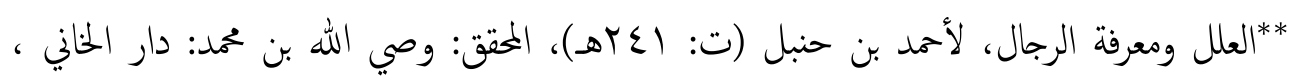

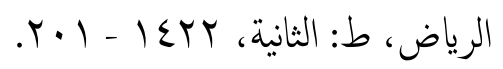

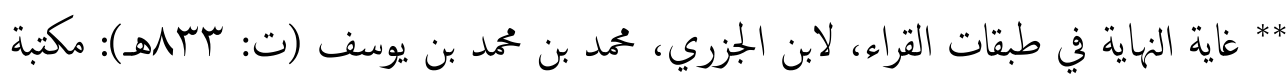

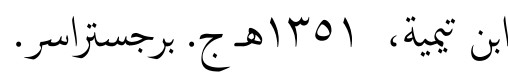



القول الحثيث في بيان مصطلح ( جائز الحديث) عند أئمة الحديث

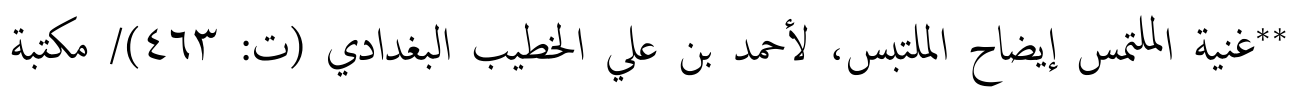

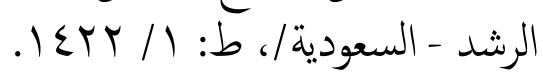

** فتح الباري شرح صحيح البخاري، لأمد بن بن علي بن حجر العسقلاني الشافعي: دار المعرفة

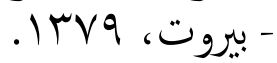

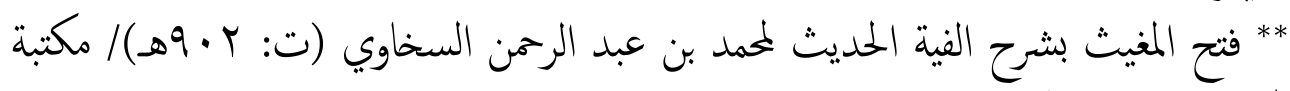

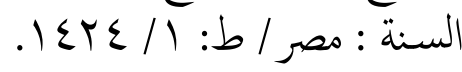

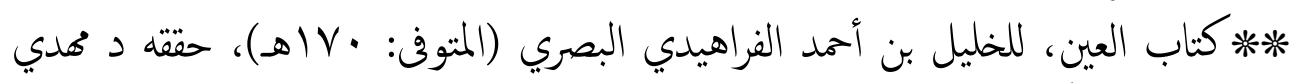
المخزوي: دار ومكتبة الهلال.

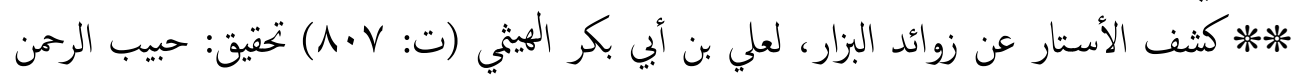

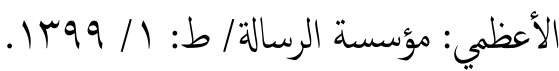

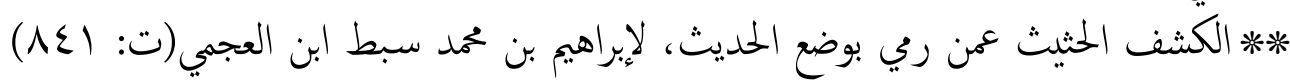

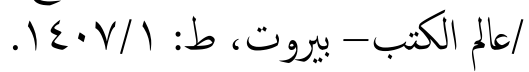

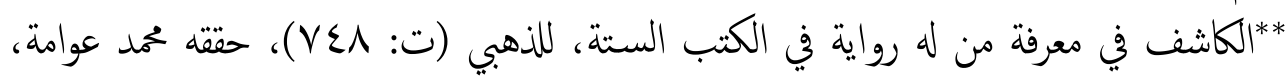

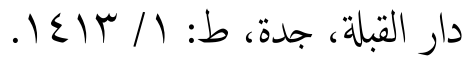

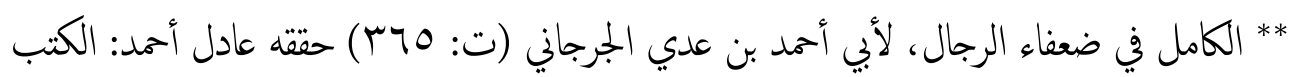

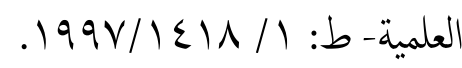

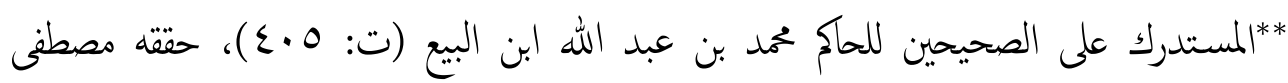

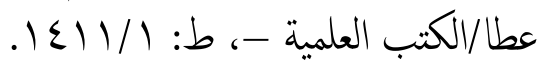

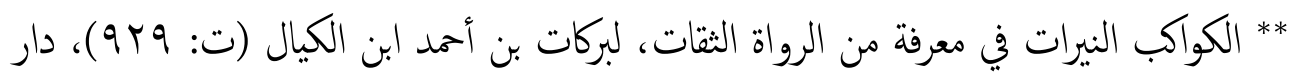

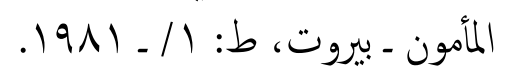

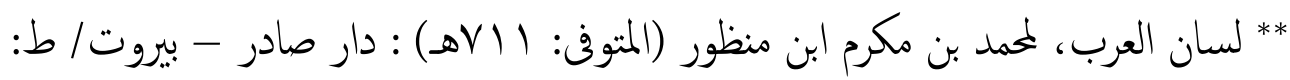

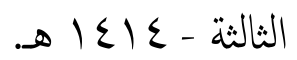

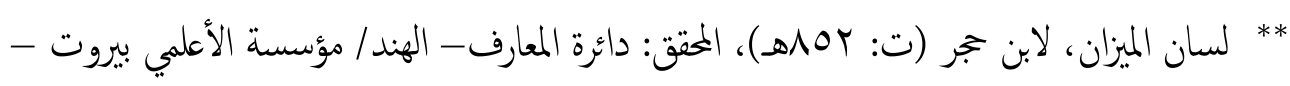

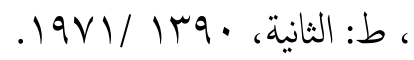

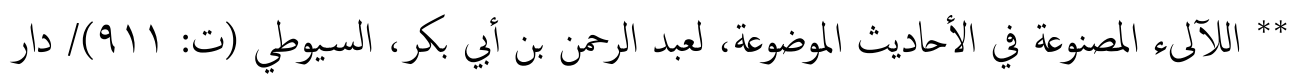

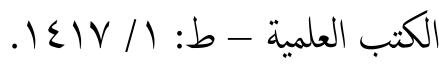

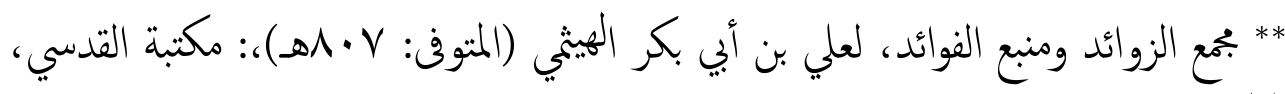

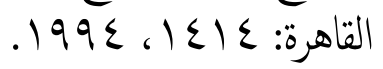




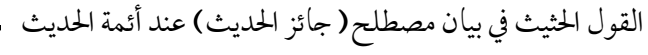

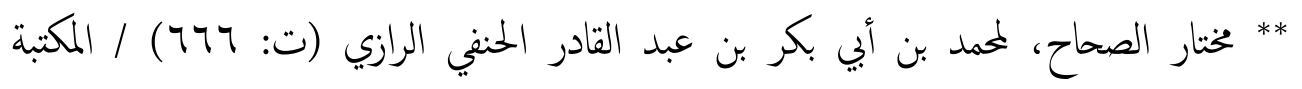

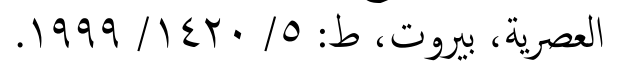

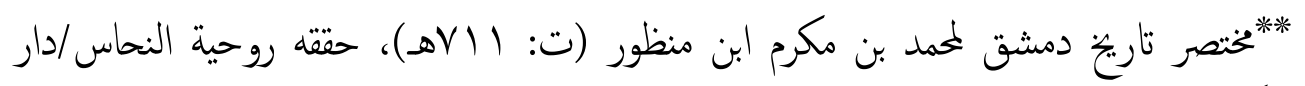

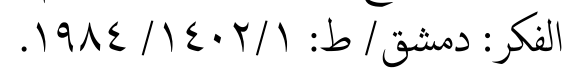

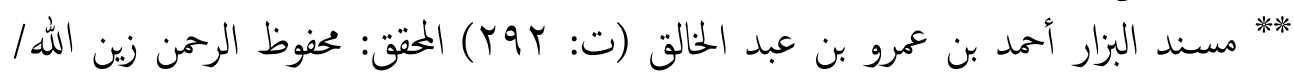

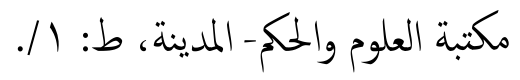

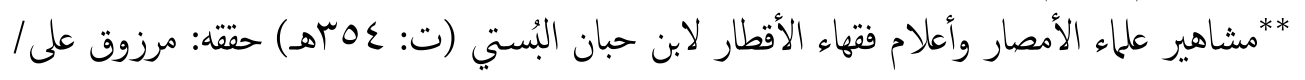

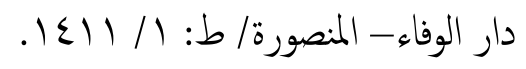

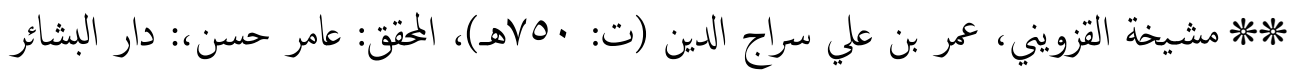

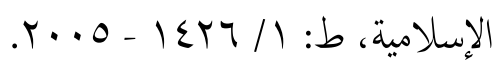

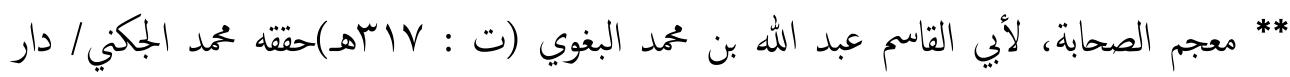

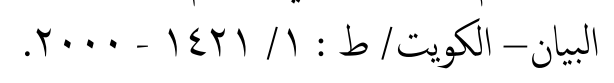

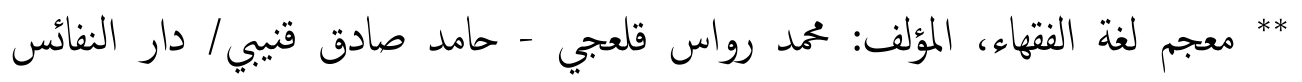

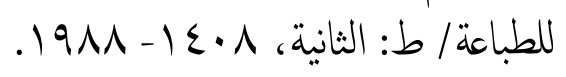

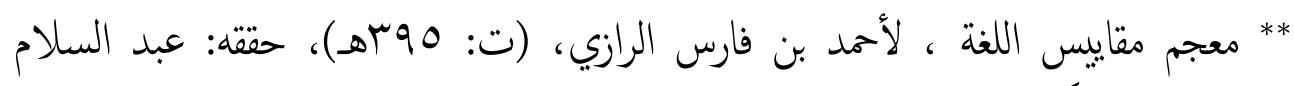

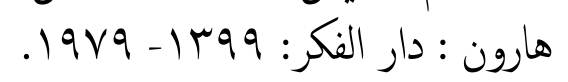

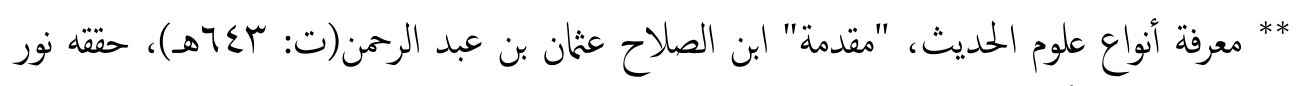

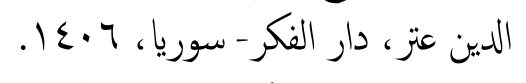

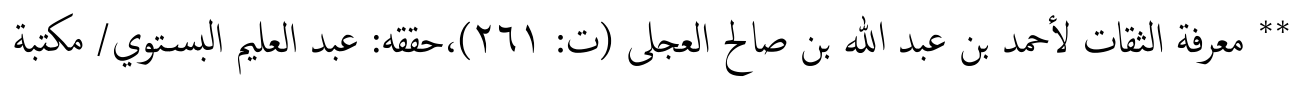

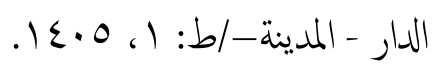

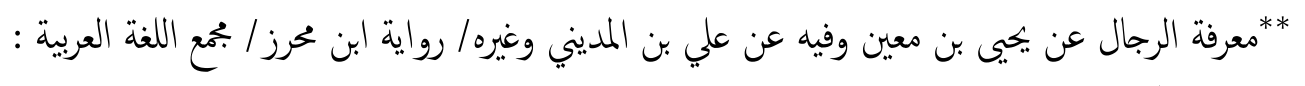

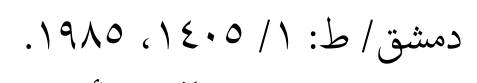

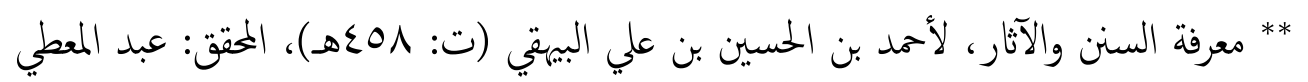

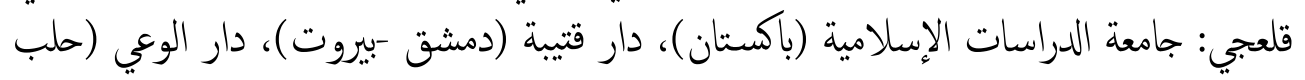

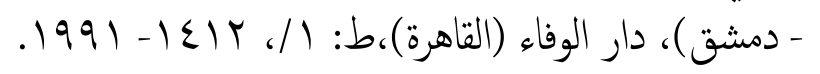

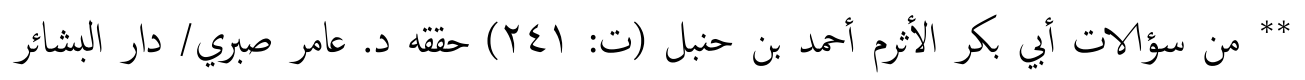

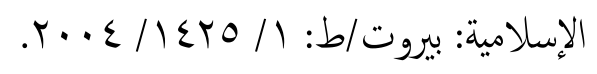



القول الحثيث في بيان مصطلح ( جائز الحديث) عند أئمة الحديث

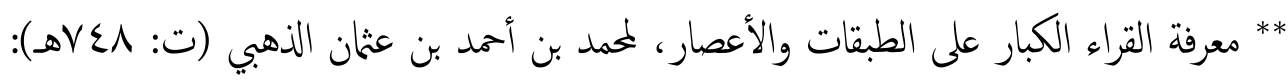

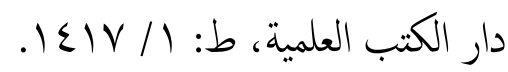

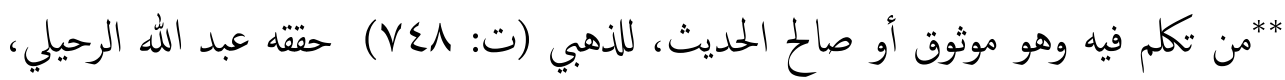
بدون: -، ط: إن / *** كن كلام أحمد بن حنبل في العلل الحديث ومعرفة الرجال، المحقق: صبحي السامرائي/ مكتبة

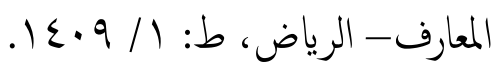

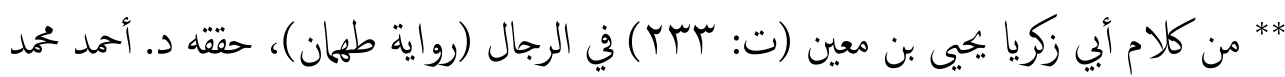

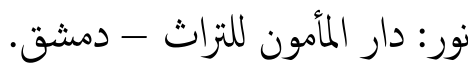

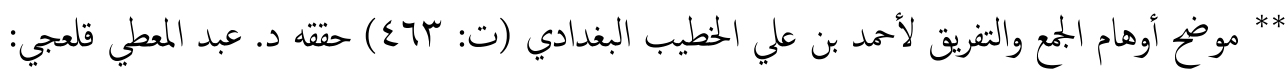

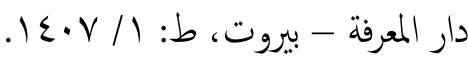

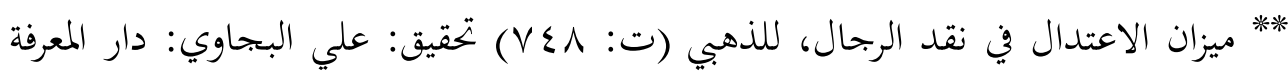

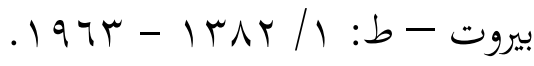

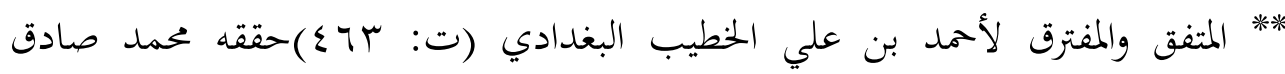

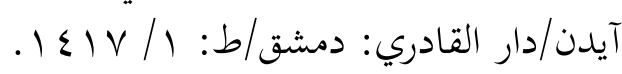

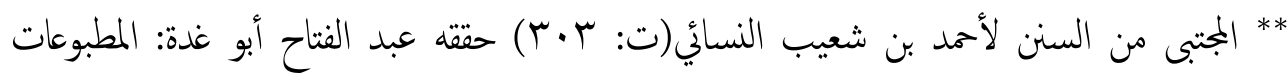

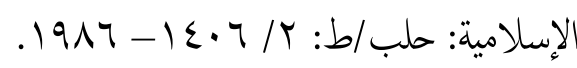

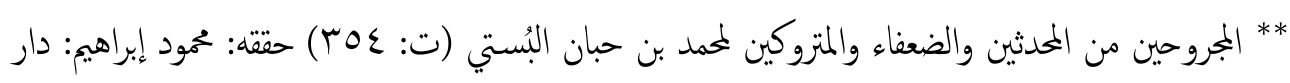

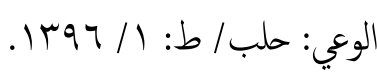
* المحلى بالآثار، لأبي محمد علي بن أحمد بن سعيد بن حزم (المتوفى:

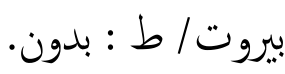

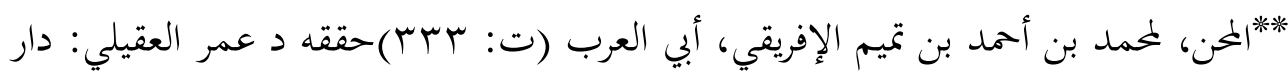

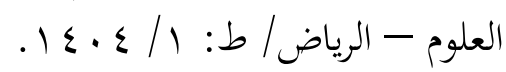

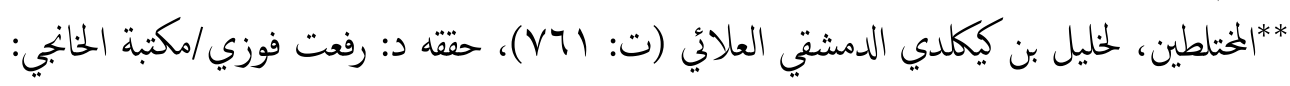

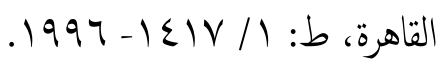

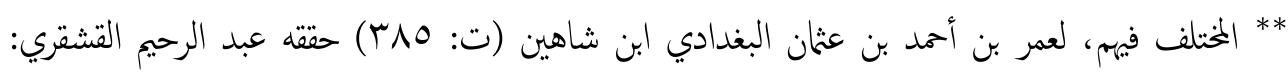

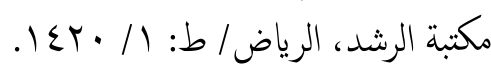

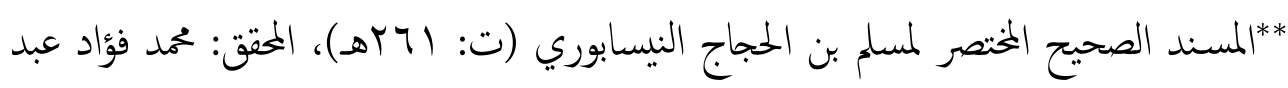
الباقي: دار إحياء التراث العربي --. 


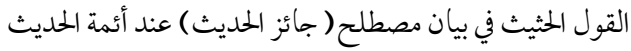

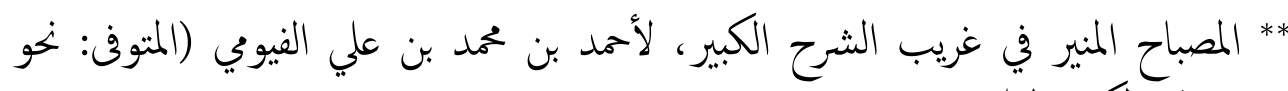

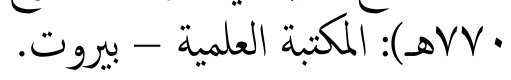

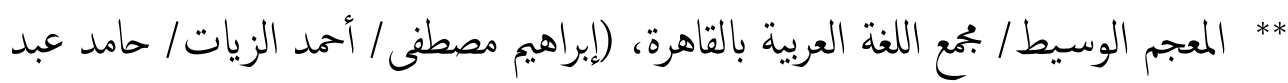
القادر / محمد النجار )/دار الدعوة.

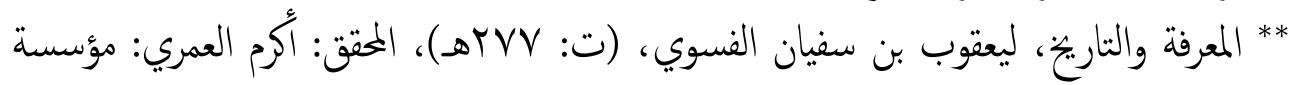

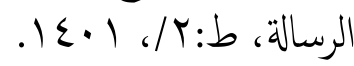

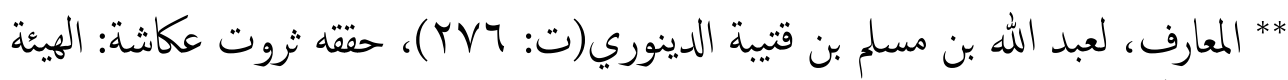

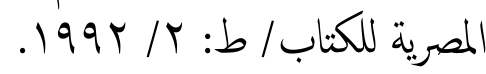

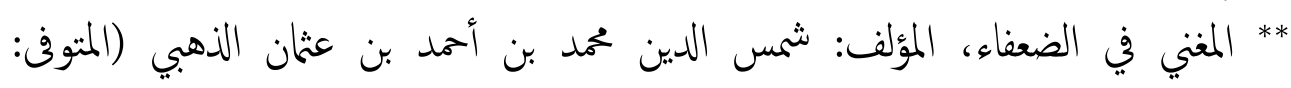

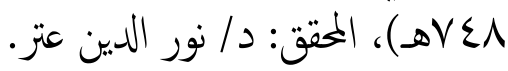

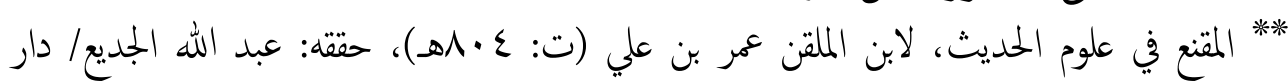

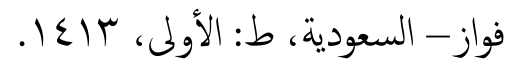

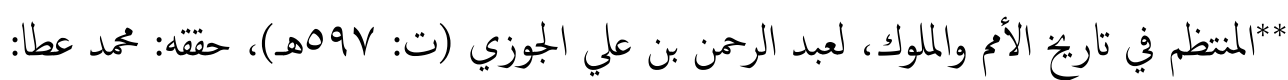

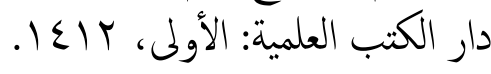

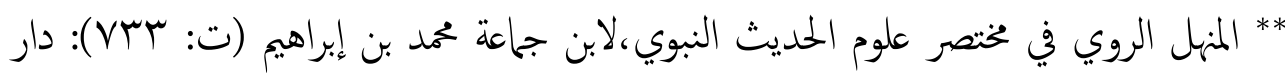

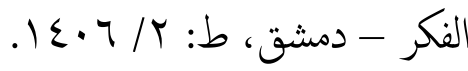

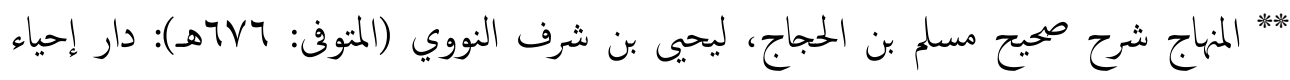

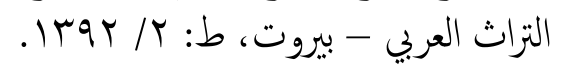

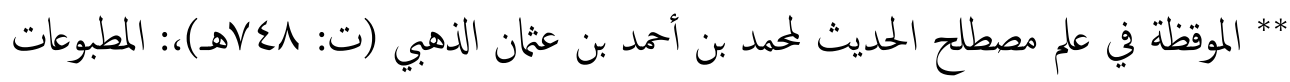

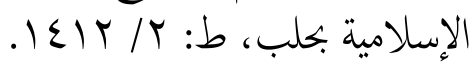

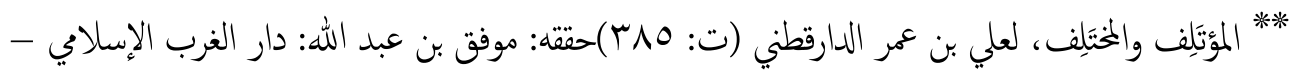

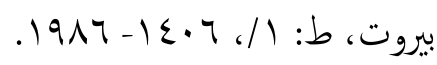




\title{
فهرس الموضوعات
}

901

هنتصهة

$9 \Delta r$

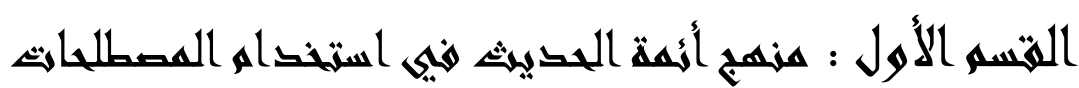
العلمبية :

المتسم الثنانبى : كراسة هناهج الأيهة الذين استخدهوا

$97 r$

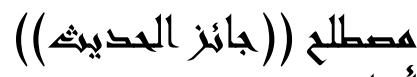

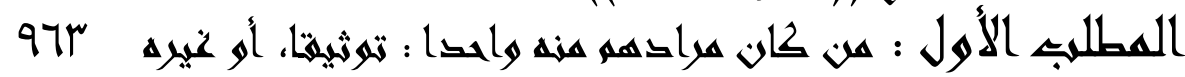

941

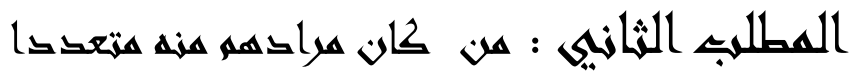

$1 \cdot \Gamma 1$

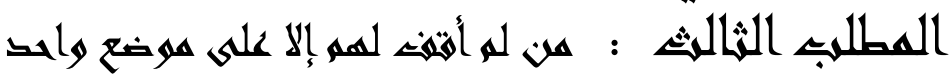

$1 \cdot r^{2} \Delta$

lorv

$1 \cdot \varepsilon V$

\author{
الخاتهة \\ ثمبتث المراجع

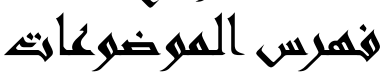

潾潾潾潾 